UNIVERSIDADE DE SÃO PAULO

FACULDADE DE FILOSOFIA, LETRAS E CIÊNCIAS HUMANAS

DEPARTAMENTO DE LETRAS MODERNAS

PROGRAMA DE PÓS-GRADUAÇÃO EM

ESTUDOS LINGUÍSTICOS E LITERÁRIOS EM INGLÊS

THIAGO PEREIRA RUSSO

ANÁLISE FORMAL DE ALL MY SONS E DE AN ENEMY OF THE PEOPLE, DE ARTHUR MILLER.

Versão Corrigida

(o exemplar original se encontra disponível na CAPH da FFLCH - Centro de Apoio à Pesquisa Histórica)

SÃO PAULO

2014 


\section{ANÁLISE FORMAL DE ALL MY SONS E DE AN ENEMY OF THE PEOPLE, DE ARTHUR MILLER.}

Dissertação apresentada à Faculdade de Filosofia, Letras e Ciências Humanas da Universidade de São Paulo, como parte dos requisitos para obtenção do título de Mestre na área de Estudos Linguísticos e Literários em Inglês.

Área de Concentração: Teatro NorteAmericano

Versão Corrigida (o exemplar original se encontra disponível na CAPH da FFLCH - Centro de Apoio à Pesquisa Histórica)

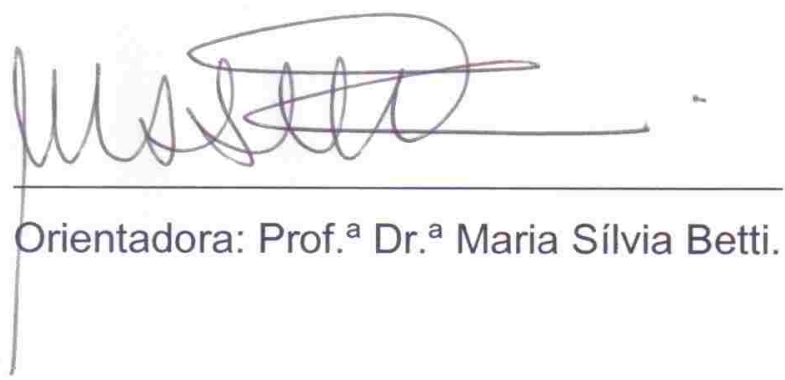

\section{SÃO PAULO}




\section{DEDICATÓRIA}

Dedico este trabalho a todos que, assim como as vítimas do macarthismo, tiveram suas vozes e consciências caladas perante as imposições de nossa sociedade. A todos os negros, gays, mulheres, Judeus e outras tantas minorias que foram e são acusadas de "bruxaria".

Dedico este trabalho a todos aqueles que, como eu, ainda acreditam na força transformadora e transcendente da Literatura, do Teatro e da Educação.

A vocês, a minha admiração e a minha dedicatória. 


\section{AGRADECIMENTOS}

Em primeiro lugar gostaria de tornar público o meu mais forte e sincero agradecimento à Maria Sílvia Betti. Desde o momento em que nos conhecemos, seu interesse e abertura possibilitaram a realização de um sonho, do meu sonho em fazer mestrado. Foram muitos os cafés, conversas, reuniões, idas a teatros e tudo mais nos quais a troca de ideias e de paixões foram inevitáveis. Tal abertura possibilitou o presente projeto que levou à realização de um outro sonho: o do reconhecimento do meu trabalho e a minha entrada para a 'Arthur Miller Society', nos Estados Unidos.

Agradeço imensamente a Sue Abbotson (Rhode Island College, Rhode Island), Stephen Marino (St.Francis College, New York) e principalmente ao David Palmer (Massachusetts Maritime Academy, Massachusetts) por terem me aceito como membro da 'Arthur Miller Society' e, mais ainda, por terem me convidado para dar uma palestra nos Estados Unidos ao lado de outros dois professores americanos brilhantes.

Toda essa realização de vários sonhos não seria possível sem o apoio incondicional dos meus pais e do meu irmão que, com respeito, paciência e incentivo, me apoiaram nos estudos desde sempre.

Aos meus amigos e familiares, obrigado por compreenderem que em alguns casos a minha ausência se fez necessária.

Este projeto também seria inviável sem as inúmeras aulas da Sílvia Anspach desde os tempos de graduação, nas quais descobri duas grandes paixões: a Literatura e a Psicanálise. Obrigado pelo incentivo constante à academia e à reflexão crítica desde os momentos mais tenros até a nossa amizade hoje em dia.

Aos amigos do grupo de estudos em Teatro Americano (Márcio, Paola e Gabriela) pelas constantes trocas e incentivos de todos os lados, e em especial ao Márcio, grande amigo com o qual troquei ideias de pesquisa, risadas e dramas.

Ao Alexandre Feldman, que desde o início se mostrou interessado e incentivador da minha pesquisa. As dicas preciosas na qualificação תודה רבה! certamente tornaram o trabalho mais maduro, coeso e focado

À Mayumi por ter aceito o convite da defesa e pela ajuda durante a pesquisa e pelo incentivo desde sempre. Não posso deixar de mencionar também meu agradecimento pelas aulas incríveis que tivemos e pela memorável discussão (em três aulas) sobre Tony Kushner. 
"People who shut their eyes to reality simply invite their own destruction, and anyone who insists on remaining in a state of innocence long after that innocence is dead turns himself into a monster."- JAMES BALDWIN. 


\section{RESUMO}

A presente pesquisa busca analisar e comparar as peças 'All My Sons' [Todos Eram Meus Filhos] (1947) e 'An Enemy of the People' [Um Inimigo do Povo] (1951), do dramaturgo norte-americano Arthur Miller (1915-2005). Em dois momentos cruciais da história norte-americana (o pós-guerra e o macarthismo, respectivamente) Miller recorre ao dramaturgo norueguês Henrik Ibsen (18281906) para responder artistica e politicamente a essas situações. Tal resposta teve um forte impacto na estrutura formal dessas peças em um período no qual Arthur Miller pensava em desistir de ser dramaturgo.

Em 'All My Sons', a Técnica Analítica, teorizada por Peter Szondi em 'Teoria do Drama Moderno', coloca no palco o passado e sua análise como elementos essenciais de ação, contradizendo fundamentalmente os princípios rigorosos do drama. A estrutura Greco-Ibseniana presente na peça é também um dos recursos pelos quais a peça alcança um efeito singular no qual forma e conteúdo interagem dialeticamente e contribuem para que Arthur Miller ocupe uma posição de destaque entre os dramaturgos norte-americanos.

Em 'An Enemy of the People', Miller recorre novamente a lbsen de maneira mais direta, sendo esta peça originalmente escrita pelo próprio norueguês e reescrita/adaptada por Arthur Miller no contexto do macarthismo. Sua forma, segundo teoriza Raymond Williams em 'Tragédia Moderna', é a da Tragédia Liberal cuja marca mais essencial é a de discutir a luta do homem contra sua sociedade. As aproximações e distanciamentos entre ambas as versões (a de Ibsen e a de Miller) levarão a uma reflexão sobre o tipo de adaptação que Arthur Miller buscou fazer e como isso representou um avanço formal.

O estudo e a elucidação do processo formal em que ambas as peças estão ancoradas, apontam para uma fusão dos ideais de Miller enquanto escritor $\mathrm{e}$ cidadão e que ajudaram a revolucionar o teatro norte-americano. Ao escrever tais peças, Miller atesta a necessidade de se pensar e refletir trazendo a fúria, a lucidez e a coerência de Henrik Ibsen para o olho do furacão nos Estados Unidos.

Palavras-Chave: Arthur Miller; Técnica Analítica; Tragédia Liberal; Macarthismo; Henrik Ibsen. 


\begin{abstract}
The research focuses on the analysis and comparison of the plays 'All My Sons' (1947) and 'An Enemy of the People' (1951), by American playwright Arthur Miller (1915-2005). In two crucially important moments of American History (Post-War period and McCarthyism, respectively) Miller turns to Norwegian playwright Henrik Ibsen (1828-1906) to respond both artistically and politically to these situations. Such a response had a strong impact on the formal structure of the plays at a time in which Arthur Miller was almost giving up on being a dramatist.
\end{abstract}

In 'All My Sons', the Analytical Technique, theorized by Peter Szondi in 'Theory of Modern Drama', places the past and its analysis on stage as essential elements of action, fundamentally contradicting the strict principles of drama. The Greco-Ibsen structure present in the play is also one of the elements that helps the play reach a remarkable effect in which form and content interact dialectically and contribute to exalt Arthur Miller's position as a singular figure among other American dramatists.

In 'An Enemy of the People', Miller turns to Ibsen once again in a direct way by choosing this play which had been originally written by the Norwegian playwright himself and now adapted by Arthur Miller in the context of McCarthyism. Its form, according to what Raymond Williams says in 'Modern Tragedy', is that of the 'Liberal Tragedy' whose most essential mark is to discuss the struggle of man against his own society. The proximities and detachments between both versions (Ibsen's and Miller's) will lead to some reflection about which kind of adaptation Arthur Miller tried to have and how it endorsed a formal advance.

The study and elucidation of the formal process in which both plays are rooted, point out to a merging of Miller's ideals as a writer and citizen which helped revolutionize the American theater. By writing such plays, Miller attests the need to think and reflect, bringing the fury, the lucidity and the coherence of Henrik Ibsen to the eye of the storm within the United States.

Keywords: Arthur Miller; Analytical Technique; Liberal Tragedy; McCarthyism; Henrik Ibsen. 


\section{SUMÁRIO}

\section{INTRODUÇÃO}

$\begin{array}{ll}\text { 1. A gênese do projeto } & \text { P.10 }\end{array}$

$\begin{array}{ll}\text { 2. Introdução } & \text { P.13 }\end{array}$

$\begin{array}{ll}\text { 3. Objetivos } & \text { P.17 }\end{array}$

$\begin{array}{ll}\text { 4. Justificativa } & \text { P.17 }\end{array}$

$\begin{array}{ll}\text { 5. Metodologia } & \text { P.19 }\end{array}$

$\begin{array}{ll}\text { 6. Pressupostos teóricos } & \text { P.22 }\end{array}$

6.1. Tragédia: conceito, evolução e desdobramentos

$\begin{array}{ll}\text { 6.2. A transformação do conceito grego de tragédia } & \text { P.30 }\end{array}$

6.3. Tragédia moderna: incorporando novos conceitos $\quad$ P.32

6.4. Tragédia Ibseniana: a inspiração da tragédia milleriana $\quad$ P.34

$\begin{array}{ll}6.5 \text { Tragédia milleriana: características e elementos recorrentes } & \text { P.36 }\end{array}$

\section{CAPÍTULO I - CONSIDERAÇÕES ANALÍTICAS SOBRE ALL MY SONS}

$\begin{array}{ll}\text { 1. Sementes dramatúrgicas } & \text { P.40 }\end{array}$

2. A inspir(ação) de Arthur Miller: a dialética entre forma e conteúdo $\quad$ P.44

3. O contexto por trás (e dentro) de All My Sons

4. Escrevendo All My Sons $\quad$ P.50

\begin{tabular}{ll} 
5. Re(ações) à peça & P.56 \\
\hline
\end{tabular}

6. A estruturação formal de All My Sons: uma tragédia analítica $\quad$ P.66

$\begin{array}{ll}\text { 6.1. Enredo } & \text { P.66 }\end{array}$

$\begin{array}{ll}\text { 6.2. Rubricas } & \text { P.92 }\end{array}$ 
CAPÍTULO II - CONSIDERAÇÕES ANALÍTICAS SOBRE AN ENEMY OF THE PEOPLE

1. McCarthy na Broadway: a resposta do teatro americano aos inimigos da

América

2. Readaptando Ibsen na América: trazendo o furacão para o olho do furacão P.121

3. A estruturação formal de An Enemy of the People P.134

3.1. Enredo P.134

3.2. Rubricas P. 175

3.3. Personagens P.180

3.4. Confronto protagonista versus forças sociais P.188

CAPÍTULO III - CONSIDERAÇÕES FINAIS ACERCA DAS DUAS PEÇAS

P.194

\section{ANEXOS}

A - Arthur Miller: banido dos palcos e aceito na sala de aula P. 203

B - Dr. Stockmann: de Berlim para São Paulo para denunciar as águas do

Brasil P. 211 


\section{INTRODUÇÃO}

\section{A GÊNESE DO PROJETO}

O interesse por Arthur Miller surgiu desde os tempos de graduação na PUCSP. A primeira obra com a qual me deparei fora The Crucible, por ocasião de um curso de Literatura Norte-Americana ministrado pela Prof ${ }^{a}$ Dr $^{a}$ Sílvia Anspach, no ano de 2005. O teatro é, desde a minha infância, uma grande paixão que carrego comigo e que aos poucos me transformou de espectador em ator e finalmente em pesquisador de teatro. $O$ teatro possui algo que as teorias não explicam, e que eu não consigo expressar com objetividade suficiente para fundamentar a minha justificativa. Li e estudei diversos dramaturgos, dentre eles: Eugene O'Neill, Tennessee Williams, Thornton Wilder, Edward Albee, Neil Simon, Amiri Baraka, mas nenhum deles me impressionou como Arthur Miller. Sua dramaturgia (em termos formais e conteudísticos) contém, de forma geral, um chamado à consciência e à responsabilidade que é feito de maneira ímpar. Em tempos atuais em que o narcisismo e a alienação andam de mãos dadas, o indivíduo fecha-se em si mesmo em busca daquilo que a cultura e suas regras (normalmente ditadas pelo sistema econômico) "impõem" a ele. Miller mostra que a negligência para com o 'social' jamais passa despercebida e/ou inconsequente e, mais do que isso, que a responsabilidade de qualquer ato é sempre do indivíduo.

Foi a percepção desta dialética das peças de Miller, em que ninguém é inocente (excluindo, portanto, visões maniqueístas tão caras ao nosso momento atual), que me chamou a atenção. A lucidez deste dramaturgo, somada à sua impressionante habilidade artística, me fizeram escolhê-lo como objeto de estudo para o mestrado e como um porta-voz de questões absolutamente importantes para o debate acadêmico e extra-acadêmico.

Passei a ler outras peças de Miller, como Death of a Salesman, A View From the Bridge e After the Fall, o que aumentou significativamente meu interesse pelo dramaturgo e, principalmente por um tema fascinante que 
aparecia em várias de suas peças: o macarthismo. A ideia inicial era a de estudar a representação do macarthismo em The Crucible, mas tal projeto já havia sido executado por Viviane Maria Leme, que mestrou-se em 2007 com " $A$ concepção da tragédia moderna em 'The Crucible' e 'A View from the Bridge', de Arthur Miller". No estudo em questão, a pesquisadora estudou a forma da tragédia moderna em ambas as peças, das quais a questão do macarthismo era inseparável. Em conversa com a orientadora chegamos a um consenso de que o que eu desejava fazer resultaria em um desdobramento reduzido do que já havia sido feito, visto que a pesquisadora supracitada havia analisado a concepção de tragédia moderna (tal como estudada por Raymond Williams) e inclusive recursos épicos.

Decidimos então estudar uma peça que contemplasse 0 meu gosto/interesse pela questão do macarthismo, mas que ao mesmo tempo não tivesse sido analisada pelo viés que gostaríamos de adotar. Por sugestão da orientadora li a peça An Enemy of the People, adaptada e reescrita no período do macarthismo por Miller, cujo autor é Ibsen. Depois de feita a leitura, enxergamos nesta obra-prima a possibilidade de resgatar uma peça pouquíssimo lembrada (principalmente quando se fala em macarthismo), e que foi a peça inaugural de Miller dentro desta problemática interessantíssima que seria novamente trabalhada posteriormente em $A$ View from the Bridge, After the Fall, Incident at Vichy etc. A pouca menção a An Enemy of the People é um fenômeno bastante comum, sendo que as associações com a temática do macarthismo costumam ser feitas somente no que se refere às três peças mencionadas acima e, certamente, à The Crucible.

An Enemy of the People possui um componente analítico acionado na forma (que é, aliás, uma raiz ibseniana bastante presente em Miller) e que é interessante de ser analisado. A obra traz não somente a "fúria" de Ibsen para os dias atuais, mas, a consciência e exposição de um escândalo social que será adaptado por Miller. Uma peça como esta merece uma atenção que the é negada por praticamente todos os críticos literários de renome, inclusive os de renome internacional como Christopher Bigsby e Harold Bloom. Um outro fator que notamos quando começamos a levantar críticas e análises já feitas da peça é que elas tratam principalmente da matéria representada, deixando 
assim de discutir o papel desempenhado pela forma. Daí a importância desta, principalmente em uma peça que é originalmente de lbsen (pai do drama moderno) e um dos exemplos ao qual Miller se ligará fortemente ${ }^{1}$. A análise da peça de Miller tratará também da peça original de Ibsen, e tentará mapear o tipo de adaptação feita pelo dramaturgo norte-americano a fim de sintonizá-la com o período macarthista. Quando Miller reescreve a peça homônima de Ibsen, o que se manteve e o que se diferenciou? É nesta peça que enxergaremos como o macarthismo se materializa tanto em seu conteúdo (ou seja, na matéria de que trata) quanto em sua forma. Decidimos, então, já que estaremos falando de forma, analisar All My Sons.

Considerada a primeira peça de sucesso comercial e de público de Miller, All My Sons é uma das peças mais importantes do dramaturgo, pois seu tema é bastante delicado e sua forma consagra e explicita a base sobre a qual se apoiará praticamente toda a dramaturgia de Miller. As confluências de conteúdo, ideias e forma dos dois dramaturgos, Miller e lbsen, são muitas, e a maior evidência disso está em All My Sons, já que a peça recorre à técnica analítica de Ibsen. Sua escolha formal é extremamente significativa e se soma à maneira única de escrever de Arthur Miller. O resultado foi um estrondoso sucesso que representou um chamado à consciência do que estava acontecendo em um período em que o país se esbaldava em sonhos e comemorações de uma vitória (o momento do pós-guerra em que os Estados Unidos surge como uma superpotência econômica e militar). Sua lucidez queria despertar as pessoas da letargia, aguçando a consciência de seu público para um momento crítico na história dos Estados Unidos (no segundo pós-guerra e macarthismo) que deveria ser mostrado. E para isso ele recorre a lbsen nas duas peças. Achamos de extrema relevância, portanto, estudar a forma de ambas como maneira de entender o conteúdo engendrado nelas de maneira a enxergá-las com mais amplitude.

\footnotetext{
${ }^{1}$ São diversas as vezes em que Miller cita Ibsen como sendo sua grande fonte de inspiração e, ao mesmo tempo, um grande dramaturgo.
} 


\section{INTRODUÇÃO}

O presente projeto se propõe a fazer uma análise formal de All My Sons e de An Enemy of the People, de Arthur Miller.

A forma de ambas apresenta mecanismos interessantes e importantes para se pensar em relações entre a dramaturgia e a história. O grande dramaturgo vencedor do Pulitzer Prize for Drama tem notoriedade entre público e crítica norte-americanos (e internacional) a partir de um de nossos objetos de pesquisa: All My Sons.

Escrita durante o período da guerra (1945), mas somente produzida após seu término (1947), All My Sons é uma peça cujo mérito repousa tanto na riqueza quanto na solidez de seu conteúdo. Ao colocar nos palcos o momento delicado no qual a sociedade norte-americana se encontrava, Miller, com sua coragem e ousadia, extrapolou o plano temático e implodiu qualquer suposição de que pudesse vir a se tornar mais um dramaturgo no estilo Broadway².

A peça trouxe aos palcos o tema do enriquecimento ilícito protagonizado por Joe Keller, um chefe de família e industrial que atua como provedor de peças de avião à Aeronáutica norte-americana durante a Segunda Guerra Mundial. O ritmo de produção e a demanda eram muito grandes, e não havia espaço/tempo para falhas e erros. Parte das peças produzidas por Keller apresenta defeitos, mas mesmo consciente desse fato ele não interrompe o fornecimento. Este ato individual (o crime cometido e o consequente enriquecimento através dele) refletirá inexoravelmente no coletivo e suas consequências serão devastadoras tanto para a família em

\footnotetext{
${ }^{2}$ A Broadway ficou conhecida e consagrada por apresentar peças de entretenimento (principalmente materializadas na forma de musicais) e comumente desviavam-se de qualquer conteúdo mais abertamente político. Há, certamente, exceções como o caso de Hairspray (1988), de Mark O'Donnell e Thomas Meehan, cujo pano de fundo é o conturbado período dos anos 1960 no qual ficam mais evidentes algumas questões de cunho sócio-político.
} 
questão quanto para o povo daquele país. Uma peça cujo enredo poderia facilmente ser tema de um thriller, ao contrário, assume nas mãos de Miller uma outra roupagem.

A forma que Miller escolhe para dar vida a seu conteúdo tem um impacto filosófico e histórico muito profundo. A técnica analítica, fio condutor desta trama sartreana, está constantemente associada a lbsen (dramaturgo a quem Miller expressa profunda admiração e reconhecimento). $O$ recurso de trazer o passado à tona por meio de diálogos sem necessariamente dramatizá-lo tem sentido e impacto muito fortes, pois essa forma aponta que o passado e suas consequências são muito mais vivos do que o presente e qualquer tentativa de escapar dele será em vão. O chamado de Miller à consciência de que o passado está infiltrado no presente é importante para que se evidenciem relações de causalidade (e isto está impregnado na forma de tragédia escolhida por Miller).

Com o objetivo político de apontar relações de causa e efeito, Miller recorre à tragédia como maneira de explicitar a rede da qual todos fazem parte e na qual não há inocentes. A ação, que transcorre em um período de vinte e quatro horas (assim como na tragédia clássica grega), conecta o tema da responsabilidade individual ao da responsabilidade coletiva. Miller busca, portanto, resolver certos problemas na forma, o que é dificilmente enxergado inclusive por críticos renomados de maneira geral. A tendência em apegarem-se ao conteúdo, os leva a reflexões que "giram em círculo" versando sobre pontos que normalmente já foram exaustivamente falados e analisados, mas, que adquirem um caráter "novo", por estarem associados a críticos bem falados ${ }^{3}$. O que se verifica constantemente na crítica norteamericana e também na brasileira é que a forma cumpre um papel que frequentemente não consegue ser enxergado ou que, quando é enxergado, acaba sendo pouco explorado, levando a conclusões que se encaixam no "ciclo canônico" da crítica que se apresenta massivamente focada no conteúdo e seus desdobramentos psicologizantes e/ou autobiográficos. A

\footnotetext{
${ }^{3}$ A quantidade de publicações de análises feitas por diferentes críticos ao redor do mundo, normalmente agrupadas em coletâneas emblemáticas, apresentam sistematicamente repetições de aspectos que não trazem coisas muito diferentes das já faladas por outros críticos em tempos mais recentes ou mais distantes.
} 
necessidade de analisar Arthur Miller é atestada pelas palavras de Iná Camargo Costa. A autora menciona que com a exceção de Szondi (...) e dos ensaios do próprio dramaturgo (...), a crítica da dramaturgia de Arthur Miller ainda tem muito trabalho pela frente 4 .

Três anos após ter escrito All My Sons e já sendo considerado um dramaturgo "de calibre" nos Estados Unidos, Miller resolve reescrever/adaptar An Enemy of the People, de Henrik Ibsen.

O diretor Robert Lewis, junto ao casal Fredric March e Florence Eldridge ${ }^{5}$ pediram a Miller que reescrevesse a obra de lbsen de 1882 como resposta e protesto à situação em que se encontravam. $\mathrm{O}$ ano era o de 1950 e o contexto político em que toda a nação se via submersa era o da perseguição política ${ }^{6}$ impulsionado pelo macarthismo.

An Enemy of the People passa-se em um balneário em cujas águas 0 Dr. Thomas Stockmann, médico sanitarista responsável, acaba de encontrar sérios sinais de contaminação. Ao fazer tal descoberta, Stockmann tem que enfrentar os interesses do poder local para que uma reforma seja feita em todo o sistema. Essa reforma, todavia, afetará não somente o lucro da cidade, uma vez que o balneário funciona como polo turístico atrativo, mas também a posição/reputação de prestígio da autoridade política local. Dr. Stockmann, que é irmão do prefeito Peter Stockmann, passa então a ser visto como destruidor não apenas da carreira do irmão mas do poder local (privado).

Uma vez mais temos, assim como em All My Sons, questões de ordem pública ligadas às de ordem privada. Interessantemente ao lançar mão da matéria prima ibseniana, Miller toma o dramaturgo norueguês como referência para ressaltar a dimensão social (e portanto, pública) de erros e

\footnotetext{
${ }^{4}$ COSTA, Iná Camargo. Panorama do Rio Vermelho: ensaios sobre o teatro americano moderno. São Paulo, Nankin, 2001, p.141-42.

${ }^{5}$ Acusados de serem comunistas, o casal sofreu represália perdendo papéis importantes na indústria cinematográfica.

${ }^{6}$ Tal perseguição resultou não somente no assassinato simbólico das ideias e convicções dos cidadãos ditos livres, como também no assassinato em sentido literal. O casal Julius e Ethel Rosenberg é um exemplo bastante icônico deste período e que é resgatado em referências literárias por Sylvia Plath (The Bell Jar, 1963), E.L Doctorow (The Book of Daniel, 1971), Tony Kushner (Angels in America, 1991), dentre outros, e inclusive na música por Billy Joel (com sua famosa canção 'we didn't start the fire').
} 
desmandos do âmbito privado. Esta dinâmica, que está fortemente sombreada pela presença do passado, fora essencial para que Miller tratasse das questões que almejava tratar, isto é, o período do pós-guerra e o macarthismo.

Em sua adaptação Miller 'reavivou' a matéria prima da dramaturgia ibseniana, mas, fez transformações que ora se aproximaram e ora se distanciaram de Ibsen. Assim sendo, estudar a forma da adaptação feita por Miller de An Enemy of the People constitui um exercício importante e necessário, visto que é nesta peça que estão as sementes dramatúrgicas (de cunho fortemente ibseniano, certamente) do macarthismo. A crítica hegemônica, ao mencionar o macarthismo, faz frequentes referências a The Crucible, A View from the Bridge, After the Fall e Incident at Vichy (este último mais dificilmente). Todavia, An Enemy foi a primeira resposta de Miller à política de caça aos "vermelhos" e apresenta aspectos formais que também impactariam posteriormente as obras supracitadas do dramaturgo.

Suas escolhas formais, adaptadas ao contexto do macarthismo nos Estados Unidos, resultam em um novo trabalho instigante e altamente politizado. A peça funciona pelo princípio da analogia entre a situação do protagonista no enredo original de lbsen (Dr. Stockmann) e a de todos os que foram citados judicialmente sob suspeita de subversão e tiveram de depor perante o comitê de atividades antiamericanas do senado $\left(\operatorname{HUAC}^{7}\right)$, presidido por Joseph McCarthy.

A análise formal de All My Sons, assim como a de An Enemy of the People, joga luz em aspectos até então pouco explorados (quando não, negligenciados) que enriquecem a fortuna crítica do dramaturgo considerado 'antiamericano' bem como refletem mais minuciosamente a história dos Estados Unidos.

É escovando a história a contrapelo, corroborando a famosa máxima de Walter Benjamin, que Miller explicitará processos ocultos da história e da

\footnotetext{
${ }^{7}$ House Un-American Activities Committee (HUAC), também conhecido como Comitê de Atividades Antiamericanas.
} 
memória e como resultado sua dramaturgia de modo geral apresenta uma versão bastante diferente daquela imposta pelo poder e autoridades vigentes, sejam eles os de 1947, sejam os de 1950 ou os de hoje.

\section{OBJETIVOS}

O objetivo primordial da pesquisa é verificar, através do princípio adorniano $^{8}$, de que maneira os conteúdos estão interligados às formas adotadas em ambas as peças. A escolha formal é, pois, grande reveladora de seu conteúdo e vice-versa. Desta maneira, a pesquisa procurará avançar no sentido de analisar criteriosamente o componente analítico acionado na forma compreendendo a configuração da raiz ibseniana em Miller. A análise de $A n$ Enemy of the People objetivará verificar como Miller transpôs uma realidade de 1882 para o contexto dos Estados Unidos dos anos 1950. Como esta alegoria/analogia é construída?

Alguns dos aspectos mais facilmente identificáveis como a reformatação da linguagem empregada por Miller serão analisados, levando em consideração a forma de tragédia utilizada nesta peça (tragédia liberal), além de outros recursos. Espera-se compreender e analisar mais profundamente as contradições que dialeticamente engendram a vida cotidiana, visto que 0 macarthismo ainda hoje é um fantasma que ronda civilizações orientais e ocidentais, mas, com diferentes nomenclaturas.

\section{JUSTIFICATIVA}

Estudar tais obras de um dramaturgo político (como foi o caso de Miller) se torna mister em tempos atuais nos quais a capacidade de pensar e refletir estão cada vez mais subordinadas aos interesses pessoais. O "crepúsculo do

\footnotetext{
${ }^{8}$ Adorno afirma que "forma é conteúdo precipitado", portanto concluímos que o estudo da forma revelará o conteúdo e vice-versa. ADORNO, Theodor W. Teoria Estética. Trad. Artur Morão. São Paulo, Martins Fontes, 1982.
} 
dever", como bem define Lipovetsky, reflete a situação atual em que o dever social que temos é para com o trabalho (e aquilo que se objetiva com ele, lucro) e para com nós mesmos (individualismo). O fato de ignorar o contrato social ${ }^{10}$ revela uma sociedade com valores éticos e morais em declínio, cedendo lugar a desejos e ganhos pessoais que muitas vezes se tornam objetivos a serem conquistados a qualquer custo.

É posicionando-se na contramão desta mentalidade que Miller colocará nos palcos a importância de se enxergar o que está além do descompromisso e da irresponsabilidade. De maneira significativa Miller, em sua dramaturgia, chamará o indivíduo à consciência apontando que este também é responsável pelo estado das coisas por participação ou por conivência. Praticamente todas as peças de Miller partem do pressuposto de que não há inocentes e para que isto fique assegurado é necessário que suas personagens experienciem a queda ${ }^{11}$. Sua dramaturgia, comumente chamada de "social", é, segundo Mason, "política", visto que enquanto o drama social é sobre a sociedade, então o drama político é sobre sua dinâmica: suas lutas, sua dialética e sua evolução ${ }^{12}$. Tal empreitada é executada por um dramaturgo que se mune de técnicas ousadas e revolucionárias para o teatro norte-americano e que enriquecem não somente a reflexão sobre estudos de dramaturgia, mas também sobre a história daquele país. Em sua trajetória dramatúrgica Miller se utiliza de recursos como técnica analítica, aspectos expressionistas, conceitos de tragédia moderna e liberal, elementos épicos etc, e o faz sempre de modo a torná-los coerentes em relação aos temas representados. Isto só é possível quando se tem um dramaturgo como ele, cuja consciência (histórica, ética, política e literária) é bastante aguçada e Ihe permite avançar em termos formais e conteudísticos.

\footnotetext{
${ }^{9}$ LIPOVETSKY, Gilles. O Crepúsculo do Dever: a ética indolor dos novos tempos democráticos. Publicações Dom Quixote, Lisboa: 1994.

${ }^{10}$ Ideia central em toda a dramaturgia milleriana.

${ }^{11}$ É preciso lembrar que a "queda" não é no sentido teológico, mas sim no sentido do despertar da consciência. Sua peça de 1964, After the Fall, é uma das que mais reflete essa ideia já prenunciada pelo próprio título.

${ }^{12}$ MASON, Jeffrey. Stone Tower: The Political Theater of Arthur Miller. The University of Michigan Press, 2011, p.2. [While social drama is about society, then political drama is about its dynamics: its struggles, its dialectics, and its evolution.]
} 
O tema do pós-guerra e suas inerentes consequências é um assunto que precisa ser sempre revisitado e analisado, já que a guerra (seja ela da natureza que for) motiva muitas nações a buscarem defender suas "verdades", sob o nome de "democracia", "liberdade", "segurança", "Deus" etc.

Ambas as peças de Miller escancaram os mecanismos escondidos atrás desses nomes mostrando não somente $o$ que a sociedade faz, mas, como ela faz, explicitando as raízes em que esta sociedade está fincada. Este arcabouço temático, que dá matéria dramatúrgica, quando analisado criteriosamente excede a análise reducionista e comum que encontramos em toda parte e que se limita a dizer somente que certa peça critica o pós-guerra, outra critica o macarthismo, uma terceira critica a Shoah e assim por diante. Há algo profundamente filosófico e desafiador naquilo que a crítica convencionou chamar simplesmente de "realismo psicológico" ${ }^{13 "}$. Há aspectos formais importantes a serem levados em conta que transcendem qualquer tentativa em reduzir a obra de Miller a algo datado e limitado pela estrutura de peça bem feita (estrutura esta à qual Miller recorrerá nas duas peças analisadas aqui).

\section{METODOLOGIA}

Para estudar tais obras nos utilizaremos da crítica histórica e dialética que considera a escolha formal do artista como grande reveladora de seu conteúdo e vice versa. A análise da forma de All My Sons buscará levantar aspectos significativos no texto ${ }^{14}$, tais como a técnica analítica, a forma de tragédia adotada, construção de personagens, uso de rubricas etc. A análise buscará entrelaçar a concepção dramatúrgica de Miller (como explicitada em seus ensaios) buscando articular de que maneira o conteúdo e a forma se encaixam dando novas dimensões à dramaturgia milleriana.

\footnotetext{
${ }^{13}$ Termo ao qual muitas das peças de Miller são associadas.

${ }^{14}$ É importante frisar que a análise será somente textual não levando em conta, portanto, encenações já realizadas. Pode haver menção às montagens que se destacaram, mas somente a título ilustrativo e não como objeto de análise.
} 
Em An Enemy of the People buscaremos levantar elementos que, por analogia, remetam ao contexto do macarthismo e em que medida eles se aproximam e/ou se distanciam do original. A entrada de Ibsen, do ponto de vista analítico, é um elemento de análise substancialmente enriquecedor, e analisar o contexto em que ele ocorre, isto é, na forma da tragédia (liberal), aponta para aspectos formais pouco discutidos. Raymond Williams nos lembra que An Enemy é tragédia liberal justamente porque seu protagonista é destruído por sua aspiração. Como esses elementos se articulam na peça? O que mais é detectável neste enlace?

Para um maior aprofundamento analítico de ambas as peças, partiremos de quatro textos que, segundo Gerald Weales ${ }^{15}$, resumem a teoria de Miller. São eles:

- "On Social Plays", de 1955, em que Miller falará sobre a importância do drama social, sobre o "drama do homem como um todo" o qual abarca não somente subjetividades do homem, mas também sua vida social;

- "The Family in Modern Drama", de 1956, em que retoma o tema da sociedade (público) e da família (privado) e diz que o papel do drama é o de abarcar as várias facetas do homem, de maneira a mostrar a rede de conexões em que esse homem se encontra;

- "Introduction to the Collected Plays", de 1957, em que deixa evidenciado o pressuposto sobre o qual se apoiam suas peças: "de que a vida tem significado", revelando portanto seu engajamento político, e a função do drama é desvendá-lo;

- "The Shadows of the Gods", de 1958, em que ressalta a importância de se compreender algo, mas esta compreensão só pode ser realizada em relação ao contexto das coisas. Logo, buscar a causa dos problemas é de suma importância.

${ }^{15}$ WEALES, Gerald (ed.). The Crucible: text and criticism. New York, Penguin Books, 1996. 
Além dos quatro ensaios citados acima, vamos nos apoiar em outros dois ensaios seminais que nos permitem entender a atualização que Miller faz da tragédia e como isso se materializa em ambas as peças: "Tragedy and the Common Man" e "The Nature of Tragedy", ambos de 1949.

Um estudo formal de All My Sons e de An Enemy of the People, partindo do pressuposto teórico no qual nos apoiaremos nesta pesquisa, poderá abrir novos caminhos para que a dramaturgia milleriana seja compreendida em outros aspectos diferenciando-se daqueles que enxergam forma e conteúdo separadamente. Tal análise textual pode, inclusive, fazer com que a dramaturgia de Miller tome outros rumos sem cair no ostracismo ${ }^{16}$, no esquecimento ou no glamour reducionista de Hollywood. Em Miller vemos um pouco de Ibsen, Tchekhov, Shaw, Sartre e Camus - grandes nomes que encabeçam o cânone teatral e filosófico dos mais importantes, mas, que são frequente e injustamente reduzidos à menção de aspectos óbvios e superficiais.

Frisamos aqui que o trabalho se volta para três objetos de estudo, mas, somente dois (os escritos por Arthur Miller) fazem parte da análise e da dissertação:

1 - An Enemy of the People (1882), de Henrik Ibsen ${ }^{17}$;

2 - All My Sons (1947), de Arthur Miller ${ }^{18}$;

3 - An Enemy of the People (1951), de Arthur Miller ${ }^{19}$.

Duas informações se fazem importantes neste momento:

\footnotetext{
${ }^{16}$ É comum ver críticos de renome tachando as obras de Miller como ultrapassadas e/ou datadas, cuja funcionalidade e relevância hoje (segundo esses críticos) são quase que descartáveis.

${ }^{17}$ Optamos pela edição de 1999 por estar disponível nas livrarias do Brasil mais facilmente.

${ }^{18}$ Optamos pela edição de 2000 por conter um prefácio escrito por Christopher Bigsby, biógrafo e estudioso de Arthur Miller, e isto poderia trazer ganho analítico.

${ }^{19}$ Optamos pela edição de 1979 que estava mais fácil de ser encontrada.
} 
a) Nos reportaremos ao original de Ibsen quando necessário para apontar aproximações e distanciamentos relevantes para se falar sobre a adaptação da obra (por Miller) para o contexto norte-americano do macarthismo;

b) Optamos por mencionar os trechos originais das peças em língua inglesa seguidos das devidas traduções (feitas por mim) localizadas nas notas de rodapé.

\section{PRESSUPOSTOS TEÓRICOS}

\subsection{TRAGÉDIA: CONCEITO, EVOLUÇÃO E DESDOBRAMENTOS.}

O vocábulo tragédia provavelmente tem sua origem de 'tragoidia', uma palavra formada por duas outras: 'trágos', que se traduz como 'bode', e 'ôidé', que quer dizer 'canto'. Desta maneira, etimologicamente, a tragédia significa o 'canto do bode'. As interpretações acerca da origem deste termo são variadas e de acordo com uma delas, conta-se que:

(...) Dioniso, em Ícaro, havia ensinado aos homens, pela primeira vez, a arte de cultivar vinhas. Assim que as videiras cresceram, um bode, acusado de tê-las destruído, fora castigado com a morte. Após persegui-lo e esquartejá-lo, os homens, sobre a sua pele, começaram a dançar e a beber até caírem

desmaiados. ${ }^{20}$

Os cantores e dançarinos, que anualmente rememoravam 0 acontecimento, travestiam-se em sátiros, que eram concebidos pela imaginação popular como 'homens-bodes'. Dentre os maiores expoentes da tragédia grega podemos citar Ésquilo (525-455 a.C), Sófocles (495-405 a.C) e Eurípedes (480?-406/405 a.C), que nos deixaram ao todo trinta e duas peças.

\footnotetext{
${ }^{20}$ SANTOS, Adilson dos. A tragédia grega: um estudo teórico. Revista de Pós Graduação de Linguística e Literatura da Universidade Federal de Pernambuco: Vol. 18, Nº1, Julho/2005, p.42-43,
} 
A primeira definição de tragédia da qual se tem conhecimento foi formulada no século IV a.C por Aristóteles e encontra-se no sexto capítulo de sua Poética ${ }^{21}$. Segundo o primeiro teórico da literatura:

(...) é pois a tragédia imitação de uma ação de caráter elevado, completa e de certa extensão, em linguagem ornamentada e com as várias espécies de ornamentos distribuídas pelas diversas partes [do drama], [imitação que se efetua] não por narrativa, mas mediante atores, e que, suscitando o "terror e a piedade, tem por efeito a purificação dessas emoções"22.

Vale lembrar que Aristóteles não chegou a postular uma "teoria da tragédia" propriamente dita: o que se tem é uma 'filosofia do fenômeno trágico', que surge com o idealismo alemão a partir de Schelling e Hegel. O procedimento adotado por Aristóteles foi o da observação das peças de maior sucesso e análise de elementos recorrentes nelas que passaram a constituir um padrão recomendado e seguido por aqueles que se debruçaram no estudo e uso da tragédia. Por meio de aulas que, depois vieram a ser escritas (provavelmente por seus discípulos), houve a possibilidade de ter aquilo a que chamamos de Poética. A maior parte das peças trágicas gregas coloca, diante dos espectadores, personagens que deverão responder por seus atos. A tragédia Antígona ${ }^{23}$, de Sófocles, é um exemplo bastante interessante: ao ir contra o Estado (a consciência coletiva), em função de seus valores religiosos e familiares, Antígona decide dar sepultura ao irmão (Polinices) e é condenada a ser sepultada viva por conta de sua hybris $^{24}$.

A questão do desequilíbrio se mostra bastante cara à questão da tragédia grega. Em outras palavras, a tragédia grega se apresenta como a manifestação estética do incerto momento da constituição de um equilíbrio

\footnotetext{
${ }^{21}$ Aristóteles. Poética. Trad. Eudoro de Souza. São Paulo: Nova Cultural, 1987.

22 Ibidem, p.205.

${ }^{23}$ Curiosamente as personagens eram reis, rainhas e pessoas da nobreza, havendo a ideia implícita de que pelo fato de pessoas ocuparem altos cargos, o efeito de sua queda seria mais impactante.

${ }^{24}$ Com este termo, intraduzível para as línguas modernas, os gregos entenderam qualquer violação da norma da medida, ou seja, dos limites que o homem deve encontrar em suas relações com os outros homens, com a divindade e com a ordem das coisas. (ABBAGNANO, 2003, p.520)
} 
novo. Um dos mais importantes e renomados estudiosos da Grécia Antiga, Jean-Pierre Vernant, nos diz o seguinte:

A cidade vivia com uma imagem do homem oriunda da tradição heróica e viu surgir então um homem totalmente diferente, o homem político, o homem cívico, o homem do direito grego, aquele cuja responsabilidade é discutida nos tribunais em termos que nada mais têm a ver com a epopéia. $A$ imagem do homem heróico, em contato direto com os deuses, agido por eles, subsiste ao lado de outro homem que, quando matou sua mulher, não pode invocar as maldições ancestrais e que é interrogado sobre o porquê e como de seu ato ${ }^{25}$.

Tal definição, portanto, remete à ideia da causação (que será explorada adiante e principalmente utilizada por Arthur Miller). A tragédia grega, mesmo com a sua definição formal restrita, plantou sementes sobre a questão da responsabilidade. Desta forma, o herói trágico grego atingirá consciência sobre isso de maneira dolorosa. Ao invés de ser um modelo, ele é colocado com suas ações perante o espectador como um problema. O período em questão, como bem nos lembra Vernant novamente, é aquele em que o homem ainda não era concebido como um agente totalmente autônomo:

(...) de fato o herói é sempre ao mesmo tempo aquele que fez uma escolha pessoalmente, que se engajou em atos que correspondem ao que ele é - a vontade de Édipo pertence a ele e o constitui - e que ao mesmo tempo os deuses prepararam tudo, de forma que o homem foi simplesmente empurrado, atravessado pelas potências divinas, e não entendeu nada do que estava fazendo. ${ }^{26}$

E é nesta dualidade que reside a mola da ação e dela surge a consciência trágica ${ }^{27}$. A noção de destino parece condicionar os caminhos do herói e levá-lo à sua condição trágica posteriormente. O ato é, portanto, produto de todos os mecanismos de caráter e do temperamento do agente e

\footnotetext{
${ }^{25}$ VERNANT, Jean-Pierre. Entre mito \& política. Trad. Cristina Murachco. São Paulo: Editora da Universidade de São Paulo, 2001, p.355.

${ }^{26}$ Ibidem, p.367-368.

${ }^{27}$ Um fato curioso é que nas primeiras versões do mito de Édipo, o herói não se pune furando os próprios olhos, mas morre tranquilamente instalado no trono de Tebas. São precisamente Sófocles e Ésquilo quem lhe dão sua versão trágica e, portanto, sua consciência. O mito (em seu estado puro) não assinalava o efeito trágico, portanto cabia ao tragediógrafo reinterpretá-lo tragicamente.
} 
produto de todas as forças que agem por meio dele. Isto conduz a um momento importante e típico à tragédia que, segundo Cézar:

(...) É este momento carregado de tensão que se fará presente na tragédia, atuando como síntese de ações passadas e eminência presente de um

desfecho sacrificial (...). ${ }^{28}$

Não é por acaso que, para Aristóteles, o espaço trágico por excelência situa-se no coração das fortes alianças. As ações catastróficas que se sucedem entre amigos - como por exemplo, o irmão que mata ou esteja em vias de matar o irmão, ou um filho o pai, ou a mãe um filho, ou um filho a mãe, ou quando acontecem outras coisas que tais ${ }^{29}$, conferem à tragédia um teor mais intenso.

A lei das três unidades, extraída de Aristóteles (mas não preconizada por ele), foi alcançada à condição de sine qua non pelo classicismo francês e serviu como regra para constituição de uma estrutura dramática rigorosa, sendo elas as de: lugar, tempo e ação.

Ambas as tragédias em análise ( $A$ ll My Sons e An Enemy of the People) se ligam fortemente à concepção aristotélica das fortes alianças sanguíneas (em termos das personagens envolvidas na peça) e isto ganha uma dimensão mais impactante ainda com a escolha do espaço. Assim como a tragédia grega, All My Sons se passa apenas em um lugar: no quintal dos Keller. O ambiente único, também comum àquele da tragédia, potencializa o efeito trágico justamente por se passar em um local onde menos se espera que haja a tragédia. É ali, onde as memórias e a história de uma família e daqueles próximos a ela, que tudo acontecerá. Um ambiente tão comum e familiar aos espectadores que aproxima cenograficamente a realidade de seus espectadores. De maneira similar, An Enemy of the People centraliza o conflito

\footnotetext{
${ }^{28}$ CÉZAR, Adelaide Caramuru. “O trágico enquanto marca do texto literário”. Signum: estudos literários, Londrina, 1999, n.2, p.139-153.

${ }^{29}$ Aristóteles, op.cit., p.213.
} 
ao mostrar que Stockmann e sua família são levados ao sacrifício com a ajuda do irmão, Peter Stockmann.

A unidade de lugar, também inspirada na interpretação da Poética, não admitia a troca de cenários. Isto era feito para evitar que a ação se tornasse impura ou inverossímil. Se o público não se movia, como poderia o cenário diante dele se mover? Haveria certamente a quebra da ilusão e a peça seria vista como encenação e algo longe da realidade. Com relação à unidade de tempo, Aristóteles não se mostra tão explícito quanto em relação à unidade de ação (que será explicada adiante). Só nos diz que:

A tragédia tenta o máximo possível se manter em uma revolução do sol ou não se afastar muito disso ${ }^{30}$.

A "revolução do sol" é um tema debatido e questionado. Alguns teóricos afirmam que em um período que ultrapasse vinte e quatro horas, pode não haver verossimilhança. Há inclusive quem diga que a obra devesse excluir doze horas (correspondentes à noite) em que nada acontece ou porque é um período que está reservado para o sono. Como nos diz Roudine, no postulado sobre a unidade de tempo:

(...) o aristotelismo se mostra impotente para pensar a convenção temporal com a qual o teatro joga livremente ${ }^{31}$.

An Enemy of the People, por exemplo, não se molda à questão do tempo e ultrapassa as vinte e quatro horas, enquanto que All My Sons se atém ao preceito aristotélico. A partir dessa imprecisão da definição aristotélica citada acima, já se podia prever que posteriormente essa unidade de tempo encontraria dificuldades para se adaptar às diferentes temáticas que viriam a surgir no drama moderno e os impasses formais que certamente também

\footnotetext{
${ }^{30}$ Ibidem, p. 249 .

${ }^{31}$ ROUDINE, Jean-Jacques. Introdução às grandes teorias do teatro. Jorge Zahar Ed, RJ. Trad. André Telles, 2003, p.43.
} 
colocariam em xeque os preceitos nos quais se apoiava a dramaturgia dita rigorosa.

A unidade de ação, segundo o preceito aristotélico, deve ser integrada para dar unidade à obra. Isto quer dizer que os acontecimentos representados ou relatados podem ser numerosos, mas devem ser ligados uns aos outros por um elo de necessidade, por um nexo causal. Tradicionalmente, a tragédia era construída de modo rigoroso e simétrico, em cinco atos: no primeiro o público era informado sobre a personagem (ou personagens) e sobre a ação geral; no segundo começaria a ação, com crescimento de tensão; no terceiro os conflitos desencadeados eram apresentados; no quarto dava-se prosseguimento à tensão; e no quinto o desenlace, a conclusão, seria trazida. Dentro do enredo havia um conjunto de conceitos que, aplicados à peça, Ihe conferiam status de uma "boa obra dramatúrgica", segundo os moldes gregos. Tais elementos, quando bem articulados, configuravam o objetivo final da tragédia: a purificação das emoções. Alguns desses elementos detectáveis em All My Sons e em An Enemy of the People (ambas a serem analisadas posteriormente), são:

A peripécia (peripetéia) consiste no estabelecimento do conflito em função de uma ação que acontece ao contrário da que estava programada e volta-se para o seu oposto. O reconhecimento (anagnórisis) é a passagem do ignorar ao saber que, normalmente, dá-se ao final do enredo trágico. O caso de Édipo ilustra bem este ponto no qual o herói passa de um estado de felicidade para um estado de infortúnio: ao investigar as circunstâncias do assassinato do rei Laio, Édipo descobre que este (e não Polybus, rei de Corinto) era seu verdadeiro pai, e que os quatro filhos que tivera com a rainha Jocasta eram, portanto, frutos de uma relação incestuosa. Isso significa que ele, Édipo, é o responsável pelo ato de transgressão que motivou o castigo que se abate sobre Tebas. A catástrofe (sparagmós) é a ação resultante da combinação da peripécia com o reconhecimento, produzindo destruição e dor no final da obra. 
Para Aristóteles, esses elementos são fundamentais para a configuração da finalidade última da tragédia: a catarse ${ }^{32}$. A purificação das emoções do público acontece em conseqüência de páthos, ou seja, do sofrimento. Enquanto a peça se dirige para o clímax, o espectador vai se envolvendo com a trama e, sentimentos de compaixão e temor, o fazem sofrer junto com o herói e seu destino. Nas tragédias de Miller, como veremos adiante, é possível (assim como na tragédia grega) enxergar a causação e o estado atual de coisas, mas, o efeito trágico não é alcançado necessariamente por pathos, mas, sim pelo conhecimento. $O$ que se objetiva nas tragédias millerianas é o despertar, não das emoções, mas da consciência individual e histórica ${ }^{33}$.

Normalmente, no início da peça, o herói trágico se apresenta como uma figura radiante, um vencedor que está no esplendor da vida. O herói será, portanto, produto de uma hybris, uma violação da medida. Essa medida, na tragédia grega, é uma ordem natural determinada pelos deuses. Desta forma, a noção de destino será extremamente importante e comum nas tragédias. $O$ erro do herói, como nos lembra Aristóteles, não é moral. A reviravolta que faz o herói passar da felicidade ao infortúnio não deve nascer de uma deficiência moral, mas, de um erro, de uma falta cometida. Essa "cegueira intelectual" não é uma grave culpa moral, desta forma, há possibilidade de o herói despertar compaixão ${ }^{34}$.

Com a situação trágica do herói há um efeito irrevogável: à medida que o seu poder político é reduzido a zero, o seu poder literário cresce a ponto de dominar toda a cena ${ }^{35}$. Isto é bastante evidente, como veremos adiante, na personagem Stockmann, de An Enemy of the People. Paradoxalmente o herói não é condenado ao silêncio, mas sim a falar. Configurado como réu no espetáculo grego, sua palavra - excessivamente lúcida e dura - (...)

\footnotetext{
${ }^{32}$ De acordo com Jean Voilquin e Jean Capelle, a tragédia, bem concebida, deve determinar no auditório, que se deixou empolgar pelas paixões expressas, um gozo que, no final do espetáculo, dá impressão de libertação e de calma, de apaziguamento, como se a obra tivesse dado ocasião para o escoamento do excesso de emoções. (1964, p.259.)

${ }^{33}$ Vale lembrar que o conceito fundamental da estética aristotélica é aquele da arte que precisa sempre causar algum prazer.

${ }^{34}$ Ricardo III e Macbeth, personagens emblemáticas da dramaturgia shakesperiana, são exemplos de figuras que contradizem fundamentalmente os preceitos aristotélicos.

${ }^{35}$ KOTHE, Flávio R. O herói. 2.ed. São Paulo: Ática, 2000, p.26.
} 
apresenta-se como um grito de indignação diante da injustiça que acredita ter se efetivado, estar se efetivando ou estar por efetivar-se ${ }^{36}$.

Um outro elemento importante que, assim como o herói trágico constitui um dos pilares mais essenciais à tragédia é o coro. Como nos dizem Vernant e Vidal-Naquet (1999:274), o coro exprime a seu modo, diante do herói atingido pelo descomedimento, a verdade coletiva, a verdade média, a verdade da cidade. Através de um discurso expresso por meio de cantos líricos corais e marcadamente solenes, o coro normalmente louva como normas de conduta a medida e a prudência. Anatol Rosenfeld também defende a importância do elemento, explicando que: o coro é uma espécie de opinião pública; contempla e objetiva, generaliza, comenta, interpreta e valoriza, positiva ou negativamente, a ação dramática dos protagonistas e antagonistas ${ }^{37}$. Em All My Sons, cuja análise será feita adiante, veremos que os vizinhos funcionam como uma espécie de coro, que também reflete a opinião pública daquele momento (1945), mas, opera e age de maneira diferente da grega. No capítulo XVIII da Poética, Aristóteles afirma que:

O coro também deve ser considerado como um dos atores; deve fazer parte do todo, e da ação ${ }^{38}$.

Novamente mencionando All My Sons, a noção de que o coro faz parte do todo e da ação, será aplicada fortemente à peça. Já ao subir o pano vemos os vizinhos oniscientes e onipresentes ${ }^{39}$. O trágico que aparecerá durante a peça traduz uma consciência dilacerada, o sentimento das contradições que dividem o homem contra si mesmo. Desta maneira a tragicidade se configura de maneira similar àquela definida por Goethe, que diz que o trágico está situado no mundo das antinomias radicais.

\footnotetext{
${ }^{36}$ CÉZAR, op.cit., p.146.

${ }^{37}$ ROSENFELD, Anatol. Prismas do teatro. Ed. Perspectiva, São Paulo, 2000, p.55.

${ }^{38}$ Aristóteles, Poética, op.cit., p.218.

${ }^{39} \mathrm{O}$ passado é invocado pelo diálogo (através da técnica analítica), mas a presença física dos vizinhos simbolicamente já evoca o passado e a lembrança, da mesma maneira que o espaço (o quintal dos Keller) o faz.
} 


\subsection{A TRANSFORMAÇÃO DO CONCEITO GREGO DE TRAGÉDIA}

A noção trágica grega apresentava certas questões que espelhavam o que se pensava em determinado tempo. Com a noção do sujeito consciente e responsável pelo que faz, Hegel, filósofo lógico-idealista, contrapõe sua dialética à lógica e à metafísica aristotélicas. Em seu pensamento, a personagem deve responder por todos os atos que pratica, os quais, uma vez praticados, tornam-se irreversíveis. Enquanto na tragédia grega as personagens eram acometidas pelo destino, o herói trágico moderno, segundo Hegel, enfrenta conflitos que dependem, mais que qualquer outra coisa, de seu próprio caráter ${ }^{40}$. A título ilustrativo Hegel comenta sobre o solilóquio to be or not to be', de Hamlet e diz que este é exatamente o caráter que pondera entre duas soluções possíveis - a vida e a morte ${ }^{41}$.

O teatro de Ibsen, pai do drama moderno, também quebra com a dramática rigorosa ao adotar a estética naturalista. Na tentativa de copiar ao máximo a vida, não pode pretender ter unidade, ser conciso, ter começo, meio e fim. Desta forma, os naturalistas ${ }^{42}$ (querendo apresentar aspectos peculiares da vida), são obrigados a produzir uma dramaturgia mais frouxa (não no sentido pejorativo) (...) O diálogo não é mais mutuamente transformador; na verdade, quase não serve de nada, como frisa Renata Pallotini ${ }^{43}$. All My Sons será um exemplo interessante e muito próximo ao que Pallottini menciona, visto que, com um discurso truncado e evasivo, beira e se aproxima inclusive ao do absurdo. Todo o naturalismo, inclusive, desmascara o homem como ser espiritualizado, com possibilidade de vida heróica. Como nos diz Anatol Rosenfeld, ele [o homem] é reduzido a um ser zoológico ${ }^{44}$, desta maneira o naturalismo abre caminho para personagens antiaristotélicas que não são mais

\footnotetext{
${ }^{40}$ PALLOTTINI, Renata. O que é dramaturgia. Ed. Brasiliense, 2011, p.36.

${ }^{41}$ Ibidem, p.38.

${ }^{42}$ É inclusive com os naturalistas que surge a teoria da quarta parede na qual o público não existia para o ator e isso o separava da plateia. O ator podia comer, beber, virar as costas, comportando-se como se não houvesse plateia.

${ }^{43}$ PALLOTTINI, Renata. op.cit., p.92.

${ }^{44}$ ROSENFELD, Anatol. A Arte do Teatro: aulas de Anatol Rosenfeld. Transcrição por Neusa Martins. São Paulo: Publifolha, 2009, p.209.
} 
necessariamente reis, homens de Estado ou heróis. Quando o herói nega todos os interesses vitais de autoconservação em favor da meta a que se propõe, afirma-se um princípio mais alto que a natureza. A determinação natural é anulada e instala-se o domínio da liberdade. Schiller afirma que $o$ trágico se revela no choque entre as determinações naturais e históricas, de um lado, e a liberdade humana de outro ${ }^{45}$. Assim sendo, a noção de destino, já mencionada anteriormente, longe de ser "inexorável", é histórica e portanto, "exorável", e capaz de ser transformada. Lesky nos diz que qualquer tentativa para determinar a essência do trágico deve partir necessariamente das palavras que Goethe disse ao Chanceler von Muller em 6 de Junho de 1824:

Todo o trágico se baseia numa contradição irreconciliável. Tão logo aparece ou se torna possível uma acomodação, desaparece o trágico. ${ }^{46}$

Goethe, com sua concepção do trágico, aproxima-se ao que Lesky define como "conflito trágico cerrado" (que será aquele encontrado em ambas as peças analisadas). Para ele, o trágico se dá de três formas diferentes: a primeira se refere ao que Lesky chama de "visão cerradamente trágica do mundo". Nela, o mundo é o lugar da aniquilação absoluta, não havendo saída, nem solução alguma para o herói trágico. A segunda se dá quando ocorre um "conflito trágico cerrado". Aqui, o conflito é insolúvel, mas pode ser parte de um todo transcendente, que dá sentido a esse conflito e permite uma saída, um escape, uma resolução. Já a terceira diz respeito a uma "situação trágica". Nela, existe o conflito entre forças contrárias, o homem não encontra uma saída, mas a destruição não é necessária, podendo, assim, haver uma solução.

\footnotetext{
${ }^{45}$ ROSENFELD, Anatol. Prismas do Teatro. op.cit., p.68-9.

${ }^{46}$ LESKY, Albin. A tragédia grega. Ed. Perspectiva, São Paulo, 1996, p.31.
} 


\subsection{TRAGÉDIA MODERNA: INCORPORANDO NOVOS CONCEITOS}

Raymond Williams abre seu livro Tragédia Moderna protestando o desdém da tradição acadêmica que julga ser tragédia somente eventos que não sejam associados ao mero sofrimento e morte. Desta maneira, ele nos diz:

[a] verdadeira chave para a moderna separação entre tragédia e 'mero sofrimento' é o ato de separar o controle ético, e mais criticamente, a ação humana da nossa compreensão da vida política e social ${ }^{47}$.

Portanto, pela linha de raciocínio da tradição/ideologia, os sofrimentos cotidianos (que são, vale dizer, banalizados como comuns), não podem ser nomeados como tragédia. A tragédia, segundo os tradicionalistas, pertence a uma experiência mais profunda e mais íntima, ao homem e não à sociedade. Aliás, foram muitas as tentativas de sistematizar uma filosofia grega trágica e transmiti-la como absoluta. Williams nos diz, ainda em Tragédia Moderna, que quando a tradição clássica deu início à imitação da tragédia grega, preocuparam-se com definições e conceitos que nem mesmo para os gregos estavam claros. Portanto, o caráter normativo estabelecido pelos seguidores de preceitos aristotélicos se firma em um solo não tão estável e firme, podendo-se questionar diversos aspectos ${ }^{48}$.

Raymond Williams coloca que a tragédia sobreviveu nos tempos modernos adquirindo um caráter liberal. Com o avanço da civilização ocidental, o conceito original de tragédia foi cada vez mais se distanciando de sua base grega, mesmo com as tentativas de normativizar e manter os postulados tradicionais. Tal distanciamento tem razões históricas que se fincam no solo movediço do individualismo: enquanto o mundo grego permanecia com unidade e coerência, o nosso (pelo caráter individualizado e narcísico) tem

\footnotetext{
${ }^{47}$ WILLIAMS, Raymond. Tragédia Moderna. Trad. Betina Bishof. São Paulo: Cosac \& Naify, 2002. p.73.

${ }_{48}$ Como mencionamos anteriormente, a própria unidade de tempo aristotélica, um dos preceitos mais fundamentais à "teorização" da tragédia, encontrou dificuldade em se estabelecer com coerência absoluta.
} 
dificuldade e, na maioria das vezes, não consegue relacionar suas vidas às de outrem.

$\mathrm{Na}$ transição do mundo clássico ao medieval, a palavra Fortuna (ou Destino, Providência, Acaso, Fado), foi bastante enfatizada. Desta maneira, as mudanças provinham de uma esfera maior, fora do controle do indivíduo ${ }^{49}$. Atrelados à ideia de Fortuna estavam os feitos de indivíduos de posições elevadas que buscavam para si sucesso e conquista. Na Renascença uma outra característica foi incorporada à noção de tragédia: além de dar ênfase a assuntos relativos a reis, a tragédia passou a ser vista como aquela que deveria ter um efeito a alcançar: sensibilizar os tiranos que estavam na plateia (catarse). No Neoclassicismo, a noção de dignidade foi agregada à tragédia. Neste período, ficou claro que mesmo as pessoas de posições elevadas não estavam isentas da Fortuna. O modo de lidar com o sofrimento é agora pelo menos tão importante quanto a maneira de vivenciá-lo ou de aprender a partir dele ${ }^{50}$. Williams chama a atenção para o fato de que a ênfase no herói isolado também é algo que se criou no período medieval (e, portanto, não foi um legado de Aristóteles), já que o próprio Aristóteles, (...) do qual essas exposições essencialmente derivam, esteve sempre mais interessado na ação como um todo do que no herói isolado ${ }^{51}$. Com a dita "tragédia secular", desvinculada de significados religiosos, houve o surgimento de novas ideias morais e metafísicas. Daí a noção do sofrimento passou a ligar-se ao erro moral e isso significou a ênfase na "justiça poética": um esquema moral dentro do qual o mal é rechaçado e o bem triunfa ${ }^{52}$. Contudo, uma concepção de mundo que versa sobre bem versus mal não explica toda a experiência humana, o que fez com que a partir daí, fosse retirada a ênfase moral.

Um comentário se faz importante, pois como nos lembra Bornheim ${ }^{53}$, toda aquela parte da dramaturgia ocidental que se subordina ao gênero tragédia foi elaborada à sombra dos gregos. Essa breve incursão na evolução

\footnotetext{
${ }^{49}$ WILLIAMS, Raymond. op.cit., p.40.

${ }^{50}$ Ibidem, p.47.

${ }^{51}$ Ibidem, p.42.

${ }^{52}$ Isso expressa, segundo WILLIAMS (p.53), uma "tradição do pensamento cristão e humanista, mas dentro dos dogmas limitados de uma sociedade burguesa complacente, e em expansão."

${ }^{53}$ BORNHEIM, Gerd. O sentido e a máscara. Ed. Perspectiva, São Paulo, 1992.
} 
do conceito de tragédia nos mostra que mesmo as ideias inspiradas na cultura clássica grega se transformaram consideravelmente, agregando novos conceitos e lançando mão de outros, de acordo com interesses e visões de determinadas épocas. Georg Lukács parece captar essa essência mutável brilhantemente ao dizer:

As formas dos gêneros não são arbitrárias. Emanam, ao contrário, em cada caso, de determinação concreta do respectivo estado social e histórico. Seu caráter e peculiaridade são determinados pela maior ou menor capacidade de exprimir os traços essenciais de dada fase histórica ${ }^{54}$.

\subsection{TRAGÉDIA IBSENIANA: A INSPIRAÇÃO DA TRAGÉDIA}

\section{MILLERIANA}

Arthur Miller, ao construir suas tragédias, leva em conta duas tradições importantes: a tragédia grega e a tragédia liberal (que deriva da tragédia moderna). O que é preciso e imprescindível dizer de antemão é que a tragédia milleriana surge em uma fase já avançada da tragédia moderna que teve início com Hegel e os hegelianos (no final do século XVIII e início do XIX), à qual Raymond Williams chamará de tragédia liberal. Baseadas no princípio de ação e reação, as ideias trágicas modernas priorizaram não o sofrimento, mas, suas causas. Desta forma, o indivíduo está acima da ética coletiva e permanece isolado, sendo este isolamento uma forte característica da tragédia moderna. Williams explica que a partir do momento em que a tragédia deixou de pertencer somente às instâncias monárquicas e se estendeu a indivíduos, ela perdeu seu caráter geral e público. Portanto, o que [no período do apogeu das tragédias gregas] havia sido uma ordem inteiramente vivenciada ligando homem, Estado e mundo tornou-se, por fim, uma ordem puramente abstrata ${ }^{55}$. O período em que a tragédia liberal se inicia é no século XIX, em um momento no qual o homem romântico descobre que vive em uma sociedade falsa e que

\footnotetext{
${ }^{54}$ LUKÁCS, Georg. Introdução à Äesthetik de Hegel apud ROSENFELD, Anatol. O teatro épico. São Paulo, Perspectiva, 2002, p.32.

${ }^{55}$ WILLIAMS, Raymond. op.cit., p.75.
} 
toda a sua energia e desejos individuais estão em contradição com essa sociedade. Assim, Williams coloca que:

No centro da tragédia liberal há uma situação isolada: um homem no ponto culminante de seus poderes e no limite de suas forças, a um só tempo aspirando e sendo derrotado, liberando energias e sendo por elas mesmas destruído. A estrutura é liberal na ênfase sobre a individualidade que se excede, e trágica no reconhecimento final da derrota ou dos limites que se impõem à vitória. ${ }^{56}$

Williams diz que a última fonte de tragédia liberal surgiria com Ibsen, num momento em que o homem luta sozinho contra essa sociedade. Stockmann, o protagonista de uma de nossas peças analisadas, é talvez o maior representante deste homem: um homem que, com sua condição solitária e heróica, encontra suas fontes na tragédia romântica e existencialista. $O$ liberalismo (romantismo) colocou frente ao homem a tarefa de negar a política da sociedade (vista como destruidora) e de imprimir valor aos seus instintos e reconhecer sua humanidade. Entretanto, com esse nível de consciência do homem que buscou superar-se e afirmar-se, o homem se deparou com a resistência da força que ele tanto negou: um sistema sócio-politico-econômico que impedia a busca do homem pleno e livre. Já que o indivíduo é parte integrante dessa sociedade, ele possui a "convicção da culpa", ou seja, ele é conivente com o estado de coisas. E esse, conclui Williams brilhantemente:

(...) é o coração da tragédia liberal, porque passamos da posição heróica do libertador individual, do eu que deseja e que vai contra a sociedade, para uma posição trágica do eu contra o eu ${ }^{57}$.

A tragédia milleriana parece se apropriar desta ideia do homem que se vê parte e até mesmo cúmplice de um "cosmos" que sempre criticou e rejeitou. É comum a menção a lbsen por parte da crítica (que enxerga nos dois dramaturgos pontos muito similares) e por parte do próprio Arthur Miller (por ser um incansável admirador do dramaturgo escandinavo). São muitos os

\footnotetext{
${ }^{56}$ Ibidem, p. 119.

${ }^{57}$ Ibidem, p. 136.
} 
elogios que Miller faz a lbsen, mas há um ponto de divergência muito claro com relação a esse impasse do herói que se vê parte de um sistema que rejeita: enquanto que para Ibsen é o "beco sem saída", Miller reconhece tal fato e avança para uma autoconsciência, que pode representar um caminho para a crise. A explicação de Miller a respeito desta questão é a seguinte:

These plays are one way of saying: "This is what you see every day, or think or feel; now I will show you what you really know but have not had the time, or the desinterestedness, or the insight, or the information to understand consciously" ${ }^{\prime \prime}$.

Desta forma, podemos enxergar na obra de Miller o efeito que ele preconiza em alguns de seus ensaios de que na tragédia vemos não somente $o$ sofrimento do homem, mas também vemos como ele poderia ter evitado seu fim sofredor ${ }^{59}$. Passemos agora a um delineamento mais específico sobre a tragédia milleriana (que ficará mais claro com as análises das peças).

\subsection{TRAGÉDIA MILLERIANA: CARACTERÍSTICAS E ELEMENTOS RECORRENTES}

Uma das insistências mais fortes de Miller é a de que o homem comum é importante à tragédia. Esta noção, contrária à clássica, é, segundo Robert $\mathrm{A}$. Martin ${ }^{60}$, a mais polêmica das colocações de Miller e está em seu ensaio "Tragedy and the Common Man", de 1949:

I believe that the common man is as apt as a subject for tragedy in its highest sense as kings were ${ }^{61}$.

\footnotetext{
${ }^{58}$ MILLER, Arthur. Introduction to the Collected Plays. In: MARTIN, Robert A; CENTOLA, Steven R, op.cit, p.122. [Essas peças são uma maneira de dizer: "isto é o que você vê todos os dias, ou pensa, ou sente; agora eu vou lhe mostrar o que você realmente sabe, mas não teve tempo, ou imparcialidade, ou discernimento, ou informação para entender conscientemente".]

${ }^{59}$ MILLER, Arthur. The Nature of Tragedy. In: MARTIN, Robert A; CENTOLA, Steven R, op.cit, p.11.

${ }^{60}$ MARTIN, Robert A. Introduction to the Original Edition. In: ibidem, p.xxvii.

${ }^{61}$ MILLER, Arthur. Tragedy and the Common Man. In: ibidem, p.3. [Eu acredito que o 'homem comum' é tão apto para ser assunto da tragédia, no seu mais alto grau, assim como os reis o eram.]
} 
Sua defesa do homem comum na tragédia expressa a crença de Miller de que este mesmo homem é capaz de compreender e de se reconhecer na tragédia. Além de sensibilizar, a tragédia é capaz de despertar um senso de conexão e de restaurar estruturas de sentimento hoje banalizadas ou condenadas à alienação. Assim, Miller diz:

(...) the tragic feeling is evoked in us when we are in the presence of a character who is ready to lay down his life, if need be, to secure one thing - his sense of personal dignity ${ }^{62}$.

A questão da dignidade pessoal ocupa, na dramaturgia de Miller, uma posição central e intrinsecamente ligada à defesa do nome e da honra, um dos aspectos mais reluzentes nas peças do autor. O que nos move nas tragédias:

(...) derives from an underlying fear of being displaced, the disaster inherent in being torn away from our chosen image of what and who we are in this world. Among us today this fear is as strong, and perhaps stronger, than it ever was. In fact, it is the common man who knows this fear best. ${ }^{63}$

Tanto em An Enemy of the People quanto em All My Sons, encontraremos personagens que demonstram valor estimado pela honra e por seus nomes, o que apontará para uma preocupação com o senso de comunidade. Este primeiro elemento (defesa do nome e da honra) detectável em praticamente todas as suas peças, fortalece um segundo elemento também bastante recorrente em sua dramaturgia: a relação entre causa e efeito. Essa preocupação com a questão da conectividade ecoa, de certa forma, as palavras de Hegel quando este fala sobre ação e reação:

\footnotetext{
${ }^{62}$ Ibidem, p.4.[(...) o sentimento trágico é evocado em nós quando estamos diante de um personagem que está pronto para sacrificar sua vida, caso seja necessário, para assegurar uma coisa: seu senso de dignidade pessoal.]

${ }^{63}$ Ibidem, p.5. [(...) deriva do medo subjacente de ser deslocado, o desastre inerente em sermos arrancados da imagem que escolhemos do que e de quem somos no mundo. Atualmente, este medo é forte e talvez mais forte do que jamais fora entre nós. Na verdade, é o homem comum que melhor conhece esse medo.]
} 
(...) above all else, tragedy requires the finest appreciation by the writer of cause and effect ${ }^{64}$.

A explicação que Miller dá ao falar de All My Sons em Introduction to the Collected Plays ${ }^{65}$, é bastante clara com relação à ideia da causação ou da conectividade: as consequências das ações são tão reais quanto as próprias ações. As ações principais (o ato de Joe Keller em fornecer peças defeituosas às forças armadas e o suicídio de Larry, seu filho) já aconteceram antes de a peça se iniciar. As ações do presente são, portanto, efeito dessas ações anteriores que são rememoradas e invocadas no presente, materializando-se inclusive cenograficamente. De maneira similar, An Enemy of the People se debruça sobre a questão de enfrentar as consequências de ações passadas: a ação e o enredo acontecem no presente, mas tomam forma e curso por causa do passado. Aliás, são os erros e desmandos cometidos pelas autoridades no passado ao construir o balneário que serão questionados e parcialmente expostos pelo futuro Inimigo do Povo.

O terceiro elemento (certamente relacionado ao de causa e efeito) é a justaposição das esferas pública e privada. O mais interessante é que ambas apresentam-se aparentemente opostas, mas são faces de uma mesma e única realidade. O "drama do homem como um todo", do qual fala Miller em seu ensaio On Social Plays, de 1955, é um exemplo contundente de que Miller concebe o homem em sua dimensão individual (privada e subjetiva) e social (pública e coletiva). A troca de ênfase entre público e privado vai aos poucos criando elos que jogam luz à relação de causa e efeito e desnudam a realidade mais complexa que está por detrás e dentro do aparente estado de coisas. Um fato extremamente curioso é que há uma atmosfera um tanto quanto idílica no início de ambas as peças: em All My Sons, há o jardim, a casa e as conversas aparentemente descompromissadas e sem importância; em An Enemy, há a casa de Stockmann, que abriga amigos em um jantar e ambiente amigáveis. Aos poucos, entretanto, vê-se que sobre o solo no qual se firmam tais

\footnotetext{
${ }^{64}$ Ibidem, p.6. [Acima de tudo, a tragédia requer o mais fino apreço do escritor pela causa e efeito.]

${ }^{65}$ Introduction to the Collected Plays. In: MARTIN, Robert; CENTOLA, Steven R., op cit, p.130.
} 
atmosferas há uma outra realidade. Sendo assim, a busca pela conectividade na tragédia milleriana acontece quando um fato da esfera privada desencadeia a ação geral que está no âmbito coletivo. O destaque à causa e efeito, na estrutura das peças, é resultado da necessidade de resgatar um senso de coletividade e conectividade que os tempos atuais parecem ter renegado.

As três características mencionadas acima sintetizam a maneira que Miller encontrou para mostrar como o conteúdo se relaciona com a forma e vice-versa. O sentido geral e público da causação é resgatado da tragédia grega por Miller, apontando para o fato de que os homens são responsáveis pelo que acontece na sociedade. Quanto ao que resgata da tragédia liberal, é justamente a dialética engendrada no conflito entre desejo individual e os limites impostos pela sociedade à realização deste (o que trará a situação paradoxal do indivíduo que precisa se destruir para se preservar).

Partiremos agora à análise das duas peças comentando suas especificidades e aspectos formais relevantes que nos auxiliem a compreender como a dialética entre forma e conteúdo se apresenta nelas. 


\section{CAPÍTULO I: CONSIDERAÇÕES ANALÍTICAS SOBRE ALL MY SONS}

\section{SEMENTES DRAMATÚRGICAS}

A análise de All My Sons é algo cuja significância e relevância são de grande valor tanto para a História das ideias do teatro quanto para a História dos Estados Unidos. Escrita em 1947, All My Sons encabeça uma das peças de maior importância do e para o dramaturgo que durante certo período foi considerado "Un-American". Arthur Miller ocupa um lugar de prestígio entre os norte-americanos ao lado de dramaturgos extremamente importantes como Eugene O'Neill, Thornton Wilder, Tennessee Williams e Edward Albee, dentre outros.

A matriz da dramaturgia de Miller é aquela cujos conteúdos são determinados historicamente e seus assuntos geralmente englobam a esfera ética de grandes crises históricas. Temas como o cenário do Pós-Guerra, a Guerra Fria, o Macarthismo e a Shoah ${ }^{66}$, foram expostos em diversas de suas peças e o impacto foi causado não somente pelo tema que abordou em diferentes épocas, mas, pelo modo (forma) como os colocou.

Representar dramaturgicamente essas diversas questões estabelecia um desafio em termos políticos, pois abordar certos temas durante períodos extremamente críticos (como foi o caso da adaptação de An Enemy of the

\footnotetext{
${ }^{66} \mathrm{O}$ termo Shoah dimensiona de maneira mais adequada o sentido daquilo que se convencionou chamar de Holocausto. O que se viu durante a Segunda Guerra mundial não foi o sacrifício de pessoas, mas, uma indústria da morte em escala nunca antes vista. A singularidade de tal acontecimento aponta para a insuficiência da linguagem diante do horror perpetrado pelos nazistas, como nos diz Feldman. Para maior compreensão do termo, ver: http://bibliaseliteraturas.files.wordpress.com/2012/11/representac3a7c3a3o-do-genocc3addio-naliteratura-hebraica.pdf.
} 
People, de lbsen, durante os anos de turbulência do macarthismo) era uma atitude bastante corajosa, e ao mesmo tempo desafiadora pela busca de soluções formais para as questões que seriam retratadas.

Um dramaturgo extremamente consciente e autoconsciente, Miller constantemente buscou formas de expressar certos conteúdos concomitantes a formas que fizessem jus a esses mesmos conteúdos.

Como falar sobre o cenário do pós-guerra nos Estados Unidos? Como denunciar perseguições políticas? Como tocar na questão da Shoah? Essas questões se colocavam continuamente para o dramaturgo e sua linha de trabalho seguiu o que Szondi coloca como uma das maiores contribuições de Hegel à interpretação da arte. "Compreender a forma como conteúdo precipitado 67 ", é enxergar na obra de arte a conexão intrínseca entre forma e conteúdo. Segundo o próprio Miller:

A work of art is not handed down from Olympus from a creature with a vision as wide as the world ${ }^{68}$.

Portanto seu trabalho partiu de um contexto historicamente localizado, cujos conteúdos seriam determinados por esta mesma história. Um trabalho artístico e político como o de Miller certamente não ficou isento de críticas. Seu experimentalismo formal e seu atrelamento a temas específicos foram estranhados e criticados por diretores, produtores e críticos renomados nos Estados Unidos e fora dele. Tal estranheza encontra parte de sua explicação,

\footnotetext{
${ }^{67}$ SZONDI, Peter. Teoria do Drama Moderno: 1880-1950. Trad. Luiz Sérgio Rêpa. São Paulo, Cosac \& Naify, 2001, p.25.

${ }^{68}$ MILLER, Arthur. Timebends: A life. New York, Grove Press, 1987, p.124. [Um trabalho artístico não é entregue do Olimpo por uma criatura com uma visão tão ampla quanto o mundo.]
} 
primeiramente porque as formas das peças de Miller seguiram diferentes rumos e incorporaram conceitos e técnicas não tão convencionais aos olhos dos críticos conservadores. Em All My Sons, por exemplo, Miller se utilizou do realismo Ibseniano; em Death of a Salesman, do expressionismo; e em The Crucible, de recursos épicos. Em segundo lugar a estranheza advinha dos conteúdos, pois uma dramaturgia política ${ }^{69}$ como a de Miller expos conteúdos que eram recebidos por grande parte da crítica com certa animosidade, já que a própria concepção de teatro nos Estados Unidos seguia um padrão completamente diferente daquele adotado e criado por Miller. Como ele mesmo atesta em Timebends, sua autobiografia:

(...) Broadway in the forties was in what might be called a "classical" phase (...) there was supposed to be nothing so impersonal as playwriting ${ }^{70}$.

Mesmo duas décadas depois desta fase se consolidar de maneira extremamente conservadora, esta visão do que constituía o teatro era endossada até por críticos mais perceptivos ou esclarecidos. Walter Kerr, um proeminente crítico da Broadway, fez a seguinte declaração: "plays that developed social or moral concepts rather than seeking simply to entertain would ultimately drive the audience out of its theaters ${ }^{71}$ ". Vale lembrar que 0 teatro nos Estados Unidos nasceu como empreendimento comercial e não teve origens eclesiásticas, palacianas ou estatais. Até a década de 1910, os

\footnotetext{
${ }^{69}$ Optamos por utilizar o termo 'dramaturgia política' mais do que 'dramaturgia social' (termo pelo qual Miller é associado por grande parte dos críticos), pois, como já citamos, Jeffrey Mason defende que: if social drama is about society, then political drama is about its dynamics: its struggles, its dialectics, and its evolution. p.2.

${ }^{70}$ MILLER, Arthur. Timebends: A life. op.cit.,p.147. [A Broadway nos anos quarenta encontrava-se no que podia ser chamada de fase "clássica" (...) não havia nada mais impessoal do que escrever peças.] ${ }^{71}$ Ibidem, p.103. [Peças que desenvolvessem conceitos sociais e morais ao invés de buscar simplesmente entreter, por fim levariam o público para fora dos teatros.]
} 
Estados Unidos não possuía uma dramaturgia típica que retratasse a vida no país. O que se via até então era a importação de matrizes culturais da Europa, as quais se convertiam nos palcos americanos em: melodramas, encenações de Shakespeare e adaptações de Clássicos da Literatura. A visão conservadora do teatro também encontra suas raízes no Puritanismo. Os puritanos não viam o teatro com bons olhos e proibiam seu aparecimento sob pretexto de má influência. Nem mesmo as peças de moral cristã tinham permissão para ser representadas. Gould nos diz que:

O teatro levou muito tempo para nascer na América e muito tempo para crescer e se tornar adulto. Desde cedo os romancistas começaram a contar suas histórias e os poetas a cantar suas canções, mas aqueles que poderiam ter escrito grandes peças se mantiveram em silêncio, porque o teatro envolvia 0 povo, o público - e, no que se referia ao público, o governo podia levantar sua mão de ferro ${ }^{72}$.

Envolver o povo era, para Miller, uma questão de honra. Um dos grandes objetivos da dramaturgia milleriana era atingir o povo, o homem comum $^{73}$. Mais do que isso, Miller defende o teatro das ideias, cujos precursores elencam nomes como os de George Bernard Shaw, Henrik Ibsen, August Strindberg, Bertolt Brecht etc. Miller acreditava que o dramaturgo tinha o objetivo de: "entertain with his brains as well as his heart" ${ }^{74 ",}$ e isso o levava a optar por temas historicamente definidos em suas peças.

\footnotetext{
${ }^{72}$ GOULD, Jean. Dentro e Fora da Broadway: o teatro moderno norte-americano. Trad. Ana Maria M. Machado. Rio de Janeiro, Bloch Editores, 1968, p.12.

73 Em "Tragedy and the Common Man" Miller defende a importância do homem comum na tragédia moderna, ao contrário da tragédia clássica que privilegia reis, príncipes e pessoas da nobreza.

${ }^{74}$ MILLER, Arthur. An Enemy of the People. New York, Penguin Books, 1979, prefácio. [Entreter com o cérebro bem como com o coração.]
} 
Uma de suas mais importantes peças foi All My Sons, que começou a ser escrita em 1945 e foi produzida em 1947. A importância da peça decorre do fato de ter sido escrita em um momento histórico de extrema relevância, de ter tratado de questões relacionadas a ele, e de ter inaugurado uma fase que havia sido precedida por inovações formais que enriqueceram a história do teatro norte-americano.

\section{A INSPIR(AÇÃO) DE ARTHUR MILLER: A DIALÉTICA ENTRE FORMA E CONTEÚDO}

All My Sons foi a primeira peça de sucesso de Miller e foi ela que o consagrou como um dos dramaturgos de maior calibre no cenário norte-americano. A peça, que começou a ser escrita durante a guerra, só chegou a ser encenada quando esta já havia acabado, e foi criteriosamente elaborada. Até esse período Miller havia escrito cerca de meia dúzia de peças sem muito sucesso de público e de crítica. Em 1944 Miller escreve The Man who had all the Luck, que foi oficialmente a primeira peça a ser produzida em âmbito profissional. Tal empreitada, contudo, não obteve êxito. A peça, que lidava essencialmente com o tema da investigação sobre qual papel exatamente o homem desenvolvia em seu destino, fracassou. Em Introduction to the Collected Plays Miller sumariza do que se tratava a peça:

It deals with a young man in a small town who, by the time he is in his midtwenties, owns several businesses, has married the girl he loves, is the father of

a child he always wanted, and is daily becoming convinced as his desires are gratified he is causing to accumulate around his own head an invisible but 
nearly palpable fund, so to speak, of retribution. The law of life, as he observes life around him, is that people are always frustrated in some important regard; and he conceives that he must be too, and the play is built around his conviction of impending disaster. The disaster never comes, even when, in effect, he tries to bring it on in order to survive it and find peace. Instead, he comes to believe in his own superiority, and in his remarkable ability to succeed ${ }^{75}$

Na realidade Miller admite que ter escrito The man who had all the Luck fora uma preparação e possivelmente uma preparação necessária para as duas peças que viriam a seguir, respectivamente: All My Sons (1947) e Death of a Salesman (1949). O fracasso de The man who had all the Luck levou Miller a refletir algumas coisas importantes sobre as escolhas temáticas e formais que havia feito até então. Miller chegou à conclusão de que havia escolhido randomicamente os temas de suas peças:

I did not perceive myself in what I had written. I had written a play about family, then a play about two brothers caught on either side of radicalism in a university, then a play about a psychologist's dilemma (...), a play about a bizarre ship's officer whose desire for death led him to piracy on the seas, a tragedy on the Cortez-Montezuma conflict, and others ${ }^{76}$.

\footnotetext{
${ }^{75}$ In: MARTIN, R.A; CENTOLA, S.R (ed). The Theater Essays of Arthur Miller. (Revised and Expanded Edition). New York, Capo Press, 1996, p.125. [Ela (a peça) lida com o enredo de um jovem de uma pequena cidade que, quando chega aos vinte e poucos anos, já possui vários negócios, casou-se com a garota que amava, é pai de um filho que sempre quis, e diariamente se convencia de que seus desejos o fizeram acumular um quase fundo palpável, por assim dizer, de retribuição. A lei da vida, como ele observa ao seu redor, é que as pessoas estão sempre frustradas em algum aspecto importante; e ele considera-se parte disso e a peça é construída ao redor de sua convicção de um iminente desastre. Tal desastre nunca chega mesmo quando, na realidade, ele tenta evocá-lo para si e finalmente encontrar paz. Em vez disso, ele passa a acreditar em sua própria superioridade e em sua habilidade extraordinária em ser bem sucedido.]

${ }^{76}$ Ibidem, p.125. [Eu não percebia a mim mesmo naquilo que eu havia escrito. Eu tinha escrito uma peça sobre família, depois uma peça sobre dois irmãos que se encontravam em lados de radicalismo diferentes em uma universidade, depois uma peça sobre o dilema de um psicólogo (...) uma peça sobre um oficial bizarro de um navio cujo desejo pela morte o levou à pirataria nos mares, uma tragédia sobre o conflito Cortez-Montezuma e outras.]
} 
O que Miller percebera era que, até então, seu trabalho não havia apresentado uma continuidade de uma peça para outra. Mas em The man who had all the Luck ele percebeu que sua motivação de escritor tinha se originado em algo que estava em seu próprio contexto: a história que ouvira de um jovem rapaz de uma cidade do Centro-Oeste dos Estados Unidos, amado e respeitado por todos em sua comunidade, e que havia conquistado grande prosperidade pessoal. Entretanto, por alguma razão desconhecida, o rapaz passou a desconfiar que todos queriam roubá-lo e dentro de um ano seus ataques obsessivos tiraram sua própria vida.

Miller reflete sobre a dificuldade que experimentara, no início de sua carreira de dramaturgo, em contraste ao momento posterior no qual pensava sobre a gênese de All My Sons:

In the past I had had less difficulty with forming a 'story' and more with the exploration of its meanings. Now, in contrast, I was working with an overwhelming sense of meaning, but however I tried I could not make the drama continuous and of a piece ${ }^{77 "}$.

Esta reflexão levou-o a reconsiderar algumas coisas, dentre elas a ideia de que os personagens que haviam sido amigos em projetos anteriores eram logicamente irmãos e tinham o mesmo pai. Ao escrever sobre a relação entre pai e filho e a busca deste último por essa relação, havia uma totalidade de sentimento que ele jamais havia conhecido antes. O ponto crucial de $A / l M y$

\footnotetext{
${ }^{77}$ Ibidem, p.126. [No passado eu tinha tido menos dificuldade em formar uma "estória" e mais com a exploração de seu significados. Agora, em contraste, eu estava trabalhando com um senso esmagador de significado, mas no entanto eu tentei e não conseguia fazer o drama contínuo e único.]
} 
Sons, que seria escrito aproximadamente três anos mais tarde, estava formado, e as raízes de Death of a Salesman ${ }^{78}$ estavam brotadas.

Antes de se lançar ao desafio de escrever All My Sons Miller havia escrito Focus (1945), seu primeiro romance. O sucesso atingido tinha sido razoável, o que em parte apontava para um potencial de ficcionista que poderia ser mais bem utilizado. Entretanto, como nos diz o crítico literário britânico Christopher Bigsby, seu biógrafo, Miller decide fazer mais uma investida no teatro ${ }^{79}$. A ideia da peça surgiu quando, certa tarde, a sogra de Miller contara que havia lido em um jornal a notícia de que em Ohio uma garota denunciara o próprio pai às autoridades. A garota o entregou às autoridades por ele ter fornecido peças defeituosas à aeronáutica durante a guerra. As bases para o enredo de All My Sons estavam lançadas e Miller estava pronto a tentar, uma última vez, escrever uma peça de teatro.

\section{O CONTEXTO POR TRÁS (E DENTRO) DE ALL MY SONS}

Miller afirmava reconhecer-se naquilo que tivesse relação com o mundo ao seu redor. O contexto histórico no momento da escritura de All My Sons era extremamente crítico para o mundo todo e principalmente para os Estados Unidos.

\footnotetext{
${ }^{78}$ Death of a Salesman explora, através da relação pai e filho, a falácia por trás do American Dream. Para tanto, a peça avança formalmente inclusive mais do que All My Sons, por incorporar elementos do expressionismo que "casam" bem com a temática discutida na peça e sobretudo por colocar no palco a simultaneidade temporal.

${ }^{79}$ [Miller decides to make one more assault on the theater.] Introdução a: All My Sons: a play in three acts. New York, Penguin Books, 2000, p.2.
} 
Os anos da década de 1930 nos Estados Unidos tinham sido definitivamente importantes para a história americana, pois neste período o país experienciara uma das maiores turbulências de sua história social e econômica, o período da Depressão. O futuro, um dos mitos fundadores dos Estados Unidos, era, naquele momento, fonte de incertezas. Antigos mitos como os sonhos, a crença fervorosa da classe média nas virtudes do trabalho duro e a perseverança para se atingir o sucesso foram desestabilizados. Tota nos diz que:

Se antes as filas eram para aproveitar a liquidação anual da Macy's em Nova lorque, agora as filas eram para ganhar um pedaço de pão distribuído por alguma instituição de caridade ${ }^{80}$.

O individualismo, base ideológica da riqueza americana, teve de ser repensado nesses tempos de crise. É também nesta década, e nas que estariam por vir, que o sentido de Americanismo ganharia fortes concepções ideológicas e políticas. Com a queda da bolsa de Nova lorque em 1929, o país encontrava-se em uma das piores crises que já havia enfrentado. O presidente Franklin Delano Roosevelt, até então governador de Nova lorque, ganha as eleições de 1932 pelo partido democrata e promete reanimar a nação e seus cidadãos. Em um discurso proferido pelo rádio em 1938, Roosevelt lembrou ao povo americano:

A democracia já desapareceu em muitas outras grande nações, não porque elas ou o seu povo não gostassem de tal regime, e sim porque haviam se cansado de desemprego e falta de assistência social, de ver seus filhos com fome, enquanto permaneciam inertes em face de confusão e fraqueza de um

${ }^{80}$ TOTA, Antonio P. Os Americanos. São Paulo, Editora Contexto, 2009, p.147. 
governo sem liderança. Acabaram, em desespero, escolhendo o sacrifício da liberdade com a esperança de conseguir alguma coisa para comer. Nós, os Estados Unidos, sabemos que as nossas instituições democráticas podem ser defendidas e também podem funcionar bem (...). O povo dos Estados Unidos concorda em defender suas liberdades a qualquer preço, e a primeira linha de defesa se encontra na proteção da segurança econômica ${ }^{81 " . ~}$

Roosevelt invocava frequentemente a retórica da liberdade do povo comum e mudava suas políticas de acordo com o ânimo da nação e entre 1933 e 1934 lança o pioneiro "New Deal ${ }^{82 " . ~ O ~ p a c o t e, ~ c o n t u d o, ~ n a ̃ o ~ t e v e ~ m u i t o ~ e ̂ x i t o ~}$ e em 1935 Roosevelt lança o "Segundo New Deal", que também não recuperou a economia e nem redistribuiu renda, mas trouxe, em certa medida, segurança econômica para muita gente e uma certa estabilidade social para o país. É justamente nesse período que a cultura norte-americana se impregna de conceitos como coragem e esperança ${ }^{83}$ para fortalecer e reconstruir suas bases.

Apesar de o New Deal não ter recuperado a economia, a Segunda Guerra Mundial, contudo, o fez. Colocando fim à Depressão e ao desemprego e dobrando o PIB do país em quatro anos, a Guerra que mostrou ao mundo o poder aniquilador do ser humano ao revelar a Shoah, deu aos Estados Unidos o status de líder econômico e militar do mundo. O plano de ação do governo na guerra era, na verdade, um novo New Deal com um maior apoio dos grandes capitalistas. A produção bélica, acelerada pela criação do War Resources Board, se alastrou por diversos setores da sociedade. As fábricas da Ford,

\footnotetext{
${ }^{81}$ Ibidem, p. 152

${ }^{82} \mathrm{O}$ New Deal foi um pacote de reformas para promover a recuperação industrial e agrícola do país.

${ }^{83}$ Um fato curioso é que, segundo aponta TOTA (2009), a famosa canção "Quem tem medo do Lobo Mau?" foi a música-hino do New Deal. Ela refletia as ideias de esperança que o New Deal pregava e o Lobo encarnava a verdadeira Depressão. Walt Disney certamente não abandonava o moralismo calvinista incluindo na história diversos ensinamentos da doutrina.
} 
Chrysler e General Motors até então focadas na produção automobilística, foram adaptadas para produzir tanques, aviões e carros de combate. No dia 29 de Dezembro de 1940, Roosevelt utilizou pela primeira vez o termo "Arsenal da Democracia $^{84 ",}$ em referência ao papel que os Estados Unidos viriam a assumir um ano antes de entrarem na guerra. Esta ideia fixou-se de forma aguda na mentalidade do americano e as mulheres (até então em sua maioria com a imagem de donas do lar), em face da necessidade de sustento das famílias, passam a ocupar empregos na indústria ${ }^{85}$. O conhecido slogan "We can do it!" levou à reintegração da mulher como força de trabalho nas fábricas ${ }^{86}$, assim como "ofuscou" a questão do racismo durante esse período de patriotismo ${ }^{87}$.

\section{ESCREVENDO ALL MY SONS}

Com o clima de prosperidade no país aos custos da guerra, Miller explica algo que o fez pensar em todo esse contexto histórico e o engajamento massivo da população nos esforços de guerra:

I bought a paper and walked down Broadway reading it. The bleeding of Russia was of staggering proportions, but the war was slowly turning against Germany. There was talk of losing half a million Americans in the onslaught against Japan

that would be coming up one day soon. I had been turned down for military service twice now. My brother was somewhere in Europe. Yet the city seemed weirdly unaffected. What meaning had all this bloodletting? If my brother died, would it make a difference? As a non-combatant I had time for such questions.

And I thought that in secret people did worry about the meaning of things but were too unsure to admit it, going along instead with the official pretensions to

\footnotetext{
${ }^{84}$ Tal termo tornou-se um slogan simbolizando que a América estaria disposta a lutar pela democracia.

${ }^{85}$ Este fato certamente atingiu um dos pilares do americanismo, o tradicionalismo, que via na figura masculina a imagem do 'tough guy'.

${ }^{86} 40 \%$ da mão de obra na indústria de aviões era composta por mulheres, embora a diferença de salário entre homem e mulher fosse mantida.

${ }^{87}$ Mais de 1.000.000 de negros serviram às forças armadas e 500.000 saíram do Sul para o Norte e Oeste.
} 
an overwhelming national purpose that would someday justify everything. I wished I could speak for those people, say what they lacked the art to say ${ }^{88}$.

Miller sentia que havia um clima de indiferença ou descaso na cidade e se perguntou, enquanto "não-combatente" que era, se este propósito nacional esmagador algum dia justificaria a permissividade de matança. Ele sabia que a política de guerra daquele momento não era desinteressada. A história de algo que estava por trás da guerra (e ao mesmo tempo dentro dela) já havia sido colocada em The Story of GI Joe ${ }^{89}$, a qual posteriormente tornou-se Situation Normal. Miller preocupou-se com o indivíduo por trás do uniforme, com o tipo de mundo que o soldado encontraria ao voltar para casa e o que aconteceria se ele se decepcionasse. Este seu raciocínio bastante profícuo revela seu desejo pessoal, cuja realização seria um ganho inclusive para a dramaturgia americana:

I wanted to write a play that would stand on the stage like a boulder that had fallen from the sky, undeniable, a fact. I had come a particular road to the point of making such a demand not only of myself but of the drama ${ }^{90}$.

\footnotetext{
${ }^{88}$ MILLER, Arthur. Timebends. op.cit., p.224. [Eu comprei um jornal e desci a Broadway lendo-o. O derramamento de sangue na Rússia era de proporções assustadoras, mas a guerra estava aos poucos virando-se contra a Alemanha. Falava-se em perder meio milhão de americanos em uma investida contra o Japão que surgiria um dia. Eu havia sido rejeitado pelo serviço militar duas vezes até então. Meu irmão estava em algum lugar da Europa. Ainda assim, a cidade parecia estranhamente não afetada. Qual o sentido de todo aquele derramamento de sangue? Se meu irmão morresse, faria diferença? Como nãocombatente eu tinha tempo para pensar em tais questões. E eu achava que as pessoas secretamente se preocupavam com o significado das coisas, mas estavam muito inseguras para admitir, seguindo, ao contrário, pretensões oficiais de uma proposta nacional esmagadora que um dia justificaria tudo. Eu desejava poder falar por essas pessoas, dizer aquilo que lhes faltava a habilidade em dizer.]

${ }^{89}$ Miller trabalhou para fazer um screenplay (um roteiro) que se chamou The Story of GI Joe que posteriormente originou um livro de reportagens publicado em 1944, sobre treinamento no exército baseado nas pesquisas feitas para a screenplay.

${ }^{90}$ MILLER, Arthur. Timebends, op.cit., p.224. [Eu queria escrever uma peça que ficasse no palco como uma pedra que tivesse caído do céu, inegável, um fato. Eu havia chegado em um estágio em que eu precisava exigir isso não somente de mim, mas do drama.]
} 
Tal aspiração explica o porque de Miller recorrer ao "pai do drama moderno", Henrik Ibsen. Ninguém melhor do que o norueguês para extrair do drama tal força e coerência. Segundo um dos maiores estudiosos norteamericanos da obra de Ibsen, Robert Brustein:

A quintessência real do ibsenismo é a resistência total a tudo o que for estabelecido, pois sua iconoclastia anarquista abrange não só as convenções correntes de sua época, mas até suas próprias crenças e convicções. ${ }^{91}$

De maneira análoga Miller se apoderou das convenções e daquilo que estava diante dele em sua época para revolucionar sua dramaturgia em sentido formal (sua apropriação da estrutura Greco-lbseniana) e conteudística (ao ousar falar da guerra e suas consequências). Ele acreditava que no período em que All My Sons fosse encenada, a guerra ainda estivesse em curso e sua expectativa, segundo ele próprio, era de que:

The play would then explode, most especially in the face of the business community with its self-advertised but profitable patriotism - and of the Communists $^{92}$.

Miller notara que as peças que havia escrito até então, bem como muitas daquelas às quais ele havia assistido, haviam sido escritas prioritariamente para temporadas teatrais, quando a prioridade delas deveria ter sido servir como testemunhos das grandes questões sociais e históricas, indo portanto

\footnotetext{
${ }^{91}$ BRUSTEIN, Robert. O teatro de protesto. Henrik Ibsen, August Strindberg e Anton Checov. Trad. Álvaro Cabral. Rio de Janeiro: Zahar, 1967, p.51.

${ }_{92}$ Ibidem, p.238. [A peça, então, explodiria, mais especialmente perante a comunidade empresarial com o seu patriotismo auto-anunciado, mas rentável - e aos comunistas.]
} 
além do âmbito do teatro comercial. Um dos objetivos mais concretos e nobres de Miller ao escrever All My Sons era:

My intention in this play was to be as untheatrical as possible. To that end, any metaphor, any image, any figure of speech, however creditable to me, was removed if it even slightly brought to consciousness the hand of a writer ${ }^{93}$.

Miller queria que as "pessoas de senso comum" confundissem suas peças com a vida, e não desejava que essas peças precisassem tomar emprestada uma licença poética para que fossem críveis. Nesse sentido Miller recorre à tragédia, pois tal estrutura, com sua essência política, resgata e afirma a relação de causalidade. Desta maneira, as pessoas comuns compreenderiam e enxergariam a rede de conexões que se desemaranharia diante de seus olhos. Miller queria que o mundo moral fosse tão evidente e real quanto o mundo imoral o era. O autor de Death of a Salesman sentia uma "necessidade Ibseniana" de contrastar os objetivos morais "elevados" com o que realmente estava acontecendo:

Like everybody else, of course, (...) I knew that profiteering on a vast scale, for one thing, was rampant and that the high moral aims of the antifascist alliance, if they were to be given any reality at all, had to be contrasted to what was actually going on in society ${ }^{94}$.

Para representar dramaturgicamente o que havia passado e mostrar as consequências disso, Miller precisou se afastar deliberada e conscientemente

\footnotetext{
${ }^{93}$ Ibidem, p.238. [Minha intenção nesta peça era ser o mais "não-teatral" possível. Para este efeito, qualquer metáfora, qualquer imagem, qualquer figura de linguagem, apesar de serem honrosos para mim, foram removidos, até mesmo se um pouco trouxesse à consciência a mão de um escritor.]

${ }^{94}$ Ibidem, p.238. [Assim como todo mundo, certamente, (...) eu sabia que lucrar em grande escala, por um lado, era implacável e que os altos fins morais da aliança antifascista, se lhes fossem dados qualquer dimensão real, tinham que ser contrastados com o que estava realmente acontecendo na sociedade.]
} 
dos padrões tradicionais da dramaturgia e recorreu à técnica analítica de lbsen.

Peter Szondi, em Teoria do Drama Moderno, coloca que a técnica analítica:

(...) é mobilizada para possibilitar a inserção da exposição no movimento dramático, retirando-lhe o seu efeito epicizante, ou para ensejar a escolha das ações "mais compósitas", estas que de início não se prestam absolutamente à forma dramática ${ }^{95}$.

Tal exposição permite compreensão do passado (através de sua análise) e isto torna-se a própria ação. Anatol Rosenfeld, também comentando a essência da peça analítica, explica que:

[a] compreensão de um vasto passado nas poucas horas de um presente dramático é típica da peça analítica em que a ação nada é senão a própria análise dos personagens e de sua situação ${ }^{96}$.

Desta forma, a técnica analítica busca revelar os motivos que estão na origem dos acontecimentos e o tempo que separa uns dos outros, subordinando desta forma, o presente ao passado. As ações do passado que aparecem no palco somente como consequência estão presentes em All My Sons e permitem que o que tem de ser dito o seja sem necessariamente dramatizar a ação. Hogan comenta o uso da técnica, apontando que:

Esta estrutura é de difícil manejo, pois o teatrólogo precisa mais explicar do que dramatizar grande parte da ação, e o peso da exposição sempre ameaça dissolver o impacto dramático da peça. Há provavelmente três maneiras principais de combater tal ameaça: pela beleza evocativa do diálogo, pela ironia e por uma hábil mistura da ação atual com explicação da ação passada. ${ }^{97}$

\footnotetext{
${ }^{95}$ SZONDI, Peter. op.cit, p.38.

${ }^{96}$ ROSENFELD, Anatol. O Teatro Épico, op.cit., p.85.

${ }^{97}$ HOGAN, Robert. Arthur Miller. Tradução de Lígia Junqueira. São Paulo: Livraria Martins Editora, 1965, p.31-32
} 
O interessante é que All My Sons representa uma tensão formal entre conteúdo (o passado focado em suas consequências) e forma (drama), no qual a ação dramática, por excelência, se move do presente para o futuro. Sendo assim, é importante frisar, como bem lembra Szondi, que:

Diferentemente do Édipo de Sófocles, o passado não está em função do presente; ao contrário, este é apenas pretexto para a evocação do passado. (...) No drama não pode haver senão um relato sobre o tempo, ao passo que sua representação direta é unicamente possível em uma forma de arte que o assume "na série de seus princípios constitutivos. Essa forma é como mostrou G. Lukács - o romance." ${ }^{98}$

Tanto em Sófocles como nas peças com técnica analítica de Ibsen (e All My Sons encaixa-se nesta última categoria), a exposição (revelação do passado) substituía quase toda a ação da trama. Entretanto, em Sófocles as revelações eram objetivas, ou seja, o mito era conhecido do público e o passado de Édipo era revelado somente a ele próprio (que desconhecia seus crimes). Surpreendido pela revelação da verdade, Édipo vê que esta não ficou confinada no passado, mas foi atualizada. Portanto, como nos diz Silva:

(...) o tema de Édipo não era o tempo passado, mas o destino terrível do herói que era o assassino do pai, o marido da mãe e irmão dos filhos. Em Ibsen acontecia justamente o contrário. A ação atual (...) nada mais era que a ocasião de desvendar aos espectadores o passado (...). Assim o passado não chegava a ser atualizado, ele mesmo tornava-se o assunto da peça. ${ }^{99}$

Enquanto que em All My Sons o presente é um pretexto para se analisar e compreender o passado e suas consequências, em Édipo Rei o presente serve para revelar coisas que acontecerão dali em diante. Miller sempre

\footnotetext{
${ }^{98}$ SZONDI, Peter. Teoria do Drama Moderno, op.cit., p.43.

${ }^{99}$ SILVA, Jane Pessoa. Dissertação de mestrado do departamento de Teoria Literária (FFLCH) sob o título de: "Ibsen no Brasil: historiografia, seleção de textos críticos e catálogo bibliográfico", 2007, Vol I, p.91.
} 
admirou a habilidade de Ibsen em construir peças a partir de eventos factuais e com desejo de reverter os erros dramatúrgicos do passado, faz da técnica analítica e de elementos da tragédia grega, sua arma mais poderosa de denúncia social:

Having for so long written in terms of what people felt rather than what they did, I turned to his Works at the time with a sense of homecoming ${ }^{100}$.

\section{RE(AÇÕES) À PEÇA}

Assim que terminou de escrever All My Sons, Miller enviou uma cópia para Herman Shumlin ${ }^{101}$, um renomado diretor e produtor da Broadway, cujo parecer foi o de não ter entendido a peça. Em uma ocasião em que Miller foi atrás de seu até então "agente" 102 Leland Hayward para saber qual era sua opinião a respeito da peça, Miller soube (através da secretária de Hayward) que o mesmo não havia lido a peça. Para piorar a situação, o "agente" estava na Califórnia e não podia ser contatado. Miller pediu seus scripts anteriores e o atual de volta à secretária e já na saída da agência foi interrompido pela mesma que o convenceu a deixar a peça para uma certa $\mathrm{Sr}^{\mathrm{a}}$.Brown ler. A Sr ${ }^{\mathrm{a}}$. Brown, da qual a secretária falou, era Kay Brown, a qual viria a ser a agente de Miller por aproximadamente quarenta anos. Kay Brown ligou para Miller no dia seguinte dizendo que havia admirado a peça e tivera algumas ideias

\footnotetext{
${ }^{100}$ MILLER, Arthur. Timebends. p.143. [Tendo por muito tempo escrito em termos daquilo que as pessoas sentiam ao invés daquilo que faziam, eu me voltei para os trabalhos dele (de Ibsen) à época com um senso de regresso a casa.]

${ }^{101}$ Herman Shumlin era um produtor de prestígio da época e havia produzido e dirigido Lillian Hellman.

${ }^{102}$ Optamos por colocar o termo entre aspas, pois segundo Miller, ele era agente somente no nome, não fazendo, assim, sua função mais básica.
} 
crucialmente importantes, como sugerir que o Group Theater $^{103}$ bem como o Theater Guild ${ }^{104}$ pudessem estar interessados em All My Sons. A chefe do Theater Guild, Theresa Helburn, alegou ter direitos sobre a peça de Miller, pois em outros tempos a mesma havia sido chefe do Bureau of New Plays quando este havia selecionado Miller para um prêmio nacional em 1937. Este fato, somado à questão de Miller achar que The Guild vinha se mostrando muito glamourosamente teatral nos últimos anos, fez com que ele não achasse que ficaria muito confortável em trabalhar com essa companhia. Miller dimensiona a importância de Kazan e Clurman, explicando em sua autobiografia:

Elia Kazan and Harold Clurman (...) had been among the creators of that thirties mixture of Stanislavsky and social protest which was the real glamour to $\mathrm{me}^{105}$.

Escolher a companhia de Kazan e Clurman foi uma decisão que não demorou muito para acontecer, mas a decisão de escolher um dos dois produtores foi de difícil escolha. Na concepção de Miller, Clurman havia sido o mentor do The Group e um fato de maior peso era que ele tinha dirigido todos os trabalhos do dramaturgo Clifford Odets nos anos 1930. Kazan, segundo relata Miller novamente em sua autobiografia, era tido como um diretor mais vital e agressivo, cujo trabalho com atores parecia ser sempre certeiro.

\footnotetext{
103 Apesar de o 'Group Theater' ter desaparecido cinco anos antes, Elia Kazan e Harold Clurman haviam feito uma parceria recentemente para produzir peças comercialmente.

${ }^{104}$ The Guild tinha sido a produtora inicial de O' Neill.

${ }^{105}$ MILLER, Arthur. Timebends. op.cit., p.269. [Elia Kazan e Harold Clurman haviam estado entre os criadores daquela mistura dos anos trinta de Stanislavsky e protesto social, a qual era o verdadeiro glamour para mim.]
} 
A estreia da peça, sob direção de Elia Kazan, chocou bastante o público e a crítica por tratar de um tema extremamente delicado e utilizar uma forma que contradizia os padrões tradicionais de se fazer teatro. Segundo relata Miller em uma passagem de Timebends, seu livro de memórias, os únicos dramaturgos de destaque que tinham tido "peças de ideias" encenadas na Broadway nos anos 1940, em contraste com as de entretenimento, eram Lillian Hellman e Clifford Odets. Logo, o teatro que não obedecia aos ditames da Broadway, não era bem-vindo. Jim Proctor, o assessor de imprensa de Miller naquele tempo pediu que ele escrevesse um texto ao 'Times' explicando a peça. Miller disse que se sentiu desconfortável com a situação:

Apart from the embarrassment of presuming to tell critics what to think, I was at a loss as to what needed elucidation ${ }^{106}$.

Uma das críticas recorrentes quando a peça estreou foi em relação à sua forma: houve críticas de que o Primeiro Ato era "lento demais". Assim como nas peças de Ibsen, o passado leva um tempo para ser trazido ao presente. Hoje em dia muitos criticam essa técnica, pois querem ação (uma tendência herdada e imposta por Hollywood) em que não é mais aceitável sentar e discutir eventos que se passaram há um ano, quando na vida, segundo o pensamento geral, as pessoas estariam muito ocupadas com 0 momento atual. All My Sons se utiliza do passado, segundo Miller:

(...) not in deference to Ibsen's method as I saw it then, but because its theme is the questions of actions and consequences ${ }^{107}$.

\footnotetext{
${ }^{106}$ Ibidem, p.134. [Além da vergonha em supor o que dizer aos críticos o que pensar, eu estava perdido com relação ao que precisava elucidação.]
} 
O passado é pesadamente documentado para que o presente seja compreendido em completude e não como um momento isolado e sem raízes. Um dos maiores desafios dramáticos que Miller considera é justamente: como dramatizar o que aconteceu antes ${ }^{108}$, algo que Ibsen conseguia com maestria. O grau de consciência da relação de causação, elucidada pela evidência daquilo que se passou para se entender o que se passa no presente, é um dos pilares mais sólidos da dramaturgia de Miller:

Dramatic characters, and the drama itself, can never hope to attain a maximum degree of consciousness unless they contain a viable unveiling of the contrast between past and present, and an awareness of the process by which the present has become what it is ${ }^{109}$.

Desta forma, o presente não é um momento isolado no tempo que age autonomamente. Ao contrário, as ações e situação do presente estão subordinadas ao passado e isso reforça constantemente a compreensão das coisas como um todo. Mais ainda, compreende-se, com Miller, que o passado foi construído e embasado por decisões e ações daqueles que participaram escolhendo ou não escolhendo.

Uma outra crítica em relação à forma, era que a peça havia sido excessivamente tramada ao ponto de ter coincidências implausíveis. A carta que Ann revela à família (e que serve como atestado de óbito de Larry), soa

\footnotetext{
${ }^{107}$ MILLER, Arthur. Introduction to the collected plays, p.132. [ (...) não em consideração ao método de Ibsen, como eu achava naquele momento, mas porque seu tema é a questão de ações e consequências.]

${ }^{108}$ Ibidem, p.133. [How to dramatize what has gone before]

${ }^{109}$ Ibidem, p.133. [Personagens dramáticas, e o drama por si, jamais podem esperar obter um grau máximo de consciência a não ser que contenham uma revelação viável do contraste entre passado e presente, e uma consciência do processo pelo qual o presente tornou-se o que é.]
} 
para muitos como um recurso artificial. Tal recurso foi alvo de questionamento, e Miller respondeu comparando-a com o mito de Édipo:

If the myth behind Oedipus allows us to stretch our commonsense judgement of its plausibility, the letter's appearance in All My Sons seems to me to spring out of Ann's character and situation and hence is far less difficult to accept than a naked stroke of fate ${ }^{110}$.

O recurso, que será analisado e comentado posteriormente, revela coisas importantes no que diz respeito à relação dialética entre a forma da peça e a matéria figurada nele.

Com relação ao conteúdo da peça, críticas e represálias não faltaram: dentro de algumas semanas após sua estreia, uma carta foi enviada ao Times por um engenheiro alegando que a trama da peça era inconcebível, visto que todos os elementos mecânicos de aeronaves eram rotineiramente inspecionados por Raio-X para que fossem detectados possíveis defeitos. A carta ainda acusou a peça de ser propaganda comunista evidente.

Em Agosto de 1947, quase sete meses após a estreia de All My Sons ${ }^{111}$, a apresentação para as tropas americanas na Alemanha foi cancelada perante um protesto fervoroso dos Católicos Veteranos de Guerra, cujo comandante, Max Sorensen admitiu que não havia visto a peça, pois estava "ocupado demais para ir ao teatro"112, todavia a condenou como "propaganda comunista" e exigiu a identidade de quem quer que fosse responsável, no departamento de

\footnotetext{
${ }^{110}$ MILLER, Arthur. Timebends, op.cit., p.134. [Se o mito por trás de Édipo nos permite esticar nosso julgamento do senso comum de sua plausibilidade, a carta em All My Sons parece-me a surgir da personalidade e situação de Ann e, portanto, é muito menos difícil de aceitar do que um golpe do destino.] ${ }^{111}$ All My Sons fora adaptada para o cinema em 1948, com direção de Irving Reis; em 1950 tornou-se uma peça radiofônica; em 1958 virou uma peça de televisão com direção de Cliff Owen; e em 1987 foi transformada em filme feito para televisão, com direção de Jack O’Brien.

${ }^{112}$ MILLER, Arthur. Timebends. op.cit., p.238.
} 
guerra, por uma ação tão ultrajante ${ }^{113}$. Nesta atitude, apesar de Joseph McCarthy aparecer mais ou menos cinco anos depois, já se podia sentir algo nessa "atmosfera" desejosa de nomear e apontar dissidentes ${ }^{114}$.

Miller, contudo, não teve que dar explicações visto que um Comitê do Senado expos o que havia se passado na 'Wright Aeronautical Corporation of Ohio' que havia trocado as etiquetas de "Rejeitado" em motores defeituosos por "Aprovado" e em parceria com inspetores subornados do exército havia mandado várias centenas dessas máquinas defeituosas para as forças armadas. Brooks Atkinson apontou, em um de seus artigos, que a Wright Corporation:

“(...) had suceeded in getting the Government to accept defective motor materials by falsification of tests, forging reports and failing to destroy defective materials ${ }^{115 "}$.

Quando All My Sons estava prestes a estrear no Colonial Theatre, em Boston, a peça sofreu censura moral por parte da Igreja Católica (que exercia poder sobre os teatros de Boston naquela época) e ameaçou publicar uma condenação à peça caso uma das falas não fosse retirada. Miller aponta o quão contraditória era a atitude, sendo que:

the raunchiest burlesque shows in America were playing on the Boston 'Strip' at the time, but these apparently were not bothersome to the moral authorities ${ }^{116 "}$

\footnotetext{
${ }^{113}$ Ibidem, p.238. [ "who in the war department was responsible for this outrageous arrangement"]

${ }^{114}$ É importante frisar que 1947 fora o ano em que Joseph McCarthy tornara-se senador pelo Estado de Wisconsin e, embora ainda não estivesse presidindo a HUAC, já se encontrava em ação dentro do cenário político daquele momento.

${ }^{115}$ Ibidem, p.238. [(...) tinha sucedido em conseguir que o governo aceitasse materiais de motores defeituosos através da falsificação de testes, forjando relatórios e fracassando na destruição de materiais defeituosos.]

${ }^{116}$ MILLER, Arthur. Echoes down the corridor: collected essays (1944-2000). Edited by Steven R. Centola. New York. Penguin Books, 2001, p.245. [as apresentações mais atrevidas e burlescas da América estavam em cartaz na Boston 'Strip' naquele tempo, mas estas aparentemente não incomodavam
} 
A fala em questão é aquela proferida por Joe Keller no Terceiro Ato: "A Man can't be a Jesus in this world". Falar o nome de 'Jesus' nos palcos de Boston era uma emissão proibida, contudo, outras atividade de teor explicitamente imoral (aos olhos dos religiosos) não sofriam sequer qualquer tipo de ressalva. O Daily Worker elogiou a peça, sublinhando que sua veracidade certamente a condenaria ao fracasso comercial. Mas, uma vez que Brooks Atkinson, um dos mais importantes críticos de teatro nos Estados Unidos, transformou a peça em sucesso popular com alguns artigos escritos no Times, as coisas mudaram. Dado o crescente sucesso comercial de All My Sons, o Daily Worker decidiu reanalisar a peça e a considerou uma apologia capciosa ao Capitalismo. Miller comenta que, para a Esquerda, a melhor prova de 'pureza artística' era o fracasso e explica o que os levou a essa conclusão:

After all, Chris Keller (...) accepts to inherit the business rather than turning into a revolutionary himself ${ }^{117}$.

Miller explica, ainda, o que na realidade estava em questão com a atitude de Chris:

In short, Chris would not become a revolutionary in real life, and in any case, that was not what the play was about ${ }^{118}$.

\footnotetext{
as autoridades morais. (Strip é aqui um vocábulo que se traduz como 'faixa', denotando uma área ou rua conhecida de um local. Mas, o destaque à tal vocábulo feito por Miller, diz respeito a analogia com o verbo 'to strip' - tirar a roupa, dando um duplo sentido)].

${ }^{117}$ Ibidem, p.237. [Afinal, Chris Keller (...) aceita herdar os negócios ao invés de transformar-se em um revolucionário.]

${ }^{118}$ Ibidem, p.237. [Em resumo, Chris não se tornaria um revolucionário na vida real, e, em todo caso, não era disso que a peça tratava.]
} 
Mesmo com todas as críticas, Miller salientou (com razão) que tinha a impressão de que a peça havia sido escrita para um teatro profético. Mesmo reconhecendo ter uma certa dificuldade em explicar este termo, Miller observou que:

Perhaps it signifies a theater, a play, which is meant to become part of the lives of its audience - a play seriously meant for people of common sense, and relevant to both their domestic lives and their daily work, but an experience which widens their awareness of connection - the filaments to the past and the future which lie concealed in 'life' 119 .

Para Bigsby, o biógrafo de Arthur Miller, All My Sons:

$(\ldots)$ is an assault on a materialism which is seen as being at odds with human values, on a capitalist drive for profits which is inimical to the elaboration of an ethics based on the primacy of human life and the necessity to acknowledge a social contract ${ }^{120}$.

A forma de All My Sons, como Miller esclarece brilhantemente:

(...) is a reflection and an expression of several forces, of only some of which I was conscious ${ }^{121}$.

\footnotetext{
${ }^{119}$ MILLER, Arthur. Introduction to the collected plays, op.cit., p.128. [Talvez ela ( $a$ peça) signifique um teatro, uma peça, que está destinada a se tornar parte da vida de seu público - uma peça verdadeiramente destinada para pessoas de senso comum, e relevante tanto para suas vidas domésticas, quanto seus trabalhos diários, mas uma experiência que amplia suas consciências de conexão - os filamentos para o passado e o futuro que jazem escondidos na 'vida'.]

${ }^{120}$ BIGSBY, Christopher C. W. All My Sons. In: Cambridge Companion to Arthur Miller, p.108. [(...) é um ataque a um materialismo que é visto como estando em dasacordo com os valores humanos, a um desejo capitalista de lucros que é hostil à elaboração de uma ética baseada na primazia da vida humana e na necessidade de reconhecer um contrato social.]

${ }^{121}$ MILLER, Arthur. Introduction to the collected plays, op.cit., p.126. [(...) é um reflexo e uma expressão de diversas forças, das quais eu estava consciente somente de algumas.]
} 
Através da estrutura de All My Sons Miller buscou criar uma forma viável que pudesse ligar a grande fratura entre a vida privada do homem e sua vida social. O termo responsabilidade talvez fosse aqui o mais adequado, pois é ele quem nos auxilia a resgatar a ideia de causação. Como Miller nos diz, a forma de All My Sons se concentra, dentre outras coisas em:

The dramatic obsession, so to speak, was with the twofold nature of the individual - his own concept of his deeds, and what turns out to be the "real" description of them ${ }^{122}$.

A discrepância entre o que o indivíduo é e aquilo que ele quer ser é verificada nas decisões que este mesmo indivíduo toma e/ou não toma. Um fato que vale a pena ser mencionado é que Jorge Andrade ${ }^{123}$, quando encontrou Miller em Nova lorque Ihe disse o seguinte:

(...) Volte para seu país, Jorge, e procure descobrir porque as pessoas são o que são e não o que gostariam de ser, e escreva sobre a diferença.

Portanto, concluimos (e isso se vê tanto em All My Sons quanto em An Enemy of the People) que é a ação que determina o caráter, e não as ideias que normalmente buscam justificá-la. Mais adiante a dramaturgia milleriana aprofunda esse ponto incorporando a noção camusiana de que é possível que o indivíduo reaja à sociedade (ponto que será comentado brevemente mais adiante).

\footnotetext{
${ }^{122}$ Ibidem, p.130. [A obsessão dramática, por assim dizer, era com a dupla natureza do indivíduo - sua própria concepção de seus atos, e o que acaba se tornando a "real" descrição deles.]

${ }^{123}$ MAGALDI, Sábato. Prefácio. In: ANDRADE, Jorge. Labirinto. Rio de Janeiro. Paz e Terra, 1978, p.11.
} 
Ao enxergar a si mesmo como agente responsável, a própria condição das personagens atingirá uma das propostas da peça que Arthur Miller define como:

(..) is designed to bring a man into the direct path of the consequences he has wrought $^{124}$.

Raymond Williams nos lembra que a tragédia é fundamentalmente associada às grandes crises do desenvolvimento humano ${ }^{125}$, o que traz uma perspectiva mais lúcida da situação real e abarca aspectos que outras formas não conseguem dar conta. A mesma história, como nos lembra Miller, poderia ter sido tema de um thriller, mas não o é. O crime de Joe Keller vai muito além de ter vendido peças defeituosas à aeronáutica. Ele é visto como tendo raízes em um certo tipo de relação do indivíduo com a sociedade e com uma certa doutrinação que o mesmo incorpora. Essa doutrinação, inerente ao próprio conceito da cultura, se explicita não somente nas relações do indivíduo com a sociedade, mas na apresentação de sua dinâmica.

A leitura e a análise de All My Sons, assim como as de uma peça de Ibsen ${ }^{126}$, nos permitem estar constantemente conscientes de: processo, mudança e evolução. Esta Tragédia Analítica que analisaremos adiante constituiu um passo à frente no que diz respeito à utilização de uma nova forma com impactantes conteúdos.

\footnotetext{
${ }^{124}$ MILLER, Arthur. Introduction to the collected plays, op.cit., p.130. [(...) é projetada para trazer um homem para o caminho direto das consequências que ele forjou.]

${ }^{125}$ WILLIAMS, Raymond. Tragédia moderna. op.cit., p.59.

${ }^{126}$ All My Sons é frequentemente comparada à peça The Wild Duck (O Pato Selvagem), de Ibsen, por aproximação de tema e, certamente, pelo uso da técnica analítica.
} 


\section{ESTRUTURAÇÃO FORMAL DE ALL MY SONS: UMA TRAGÉDIA}

\section{ANALÍTICA.}

\subsection{ENREDO}

O enredo de All My Sons está apoiado em uma construção dramática tradicional. A linha de tensão ascensional da peça apresenta exposição, complicação, clímax e desfecho, mas, diferentemente do que a tradição recomenda, ela não dramatiza o presente. O tempo presente que se vê na trama é pura evocação do passado e de suas memórias através da técnica analítica, já citada anteriormente.

Desta maneira, a ação nada é senão a própria análise das personagens e de sua situação. Em todas as partes do enredo (que serão exploradas adiante) essa dinâmica se mantém e garante, ao final, a compreensão vasta do momento presente como um tempo enraizado e ligado ao passado. Talvez uma das questões mais fascinantes que permeiam o enredo todo da peça é que 0 passado é constantemente evocado, mas, na medida em que se aprofundam as reflexões e questões desse passado, as personagens se desviam dele com assuntos diferentes ${ }^{127}$. Tal enredo, como mencionamos anteriormente, é composto por exposição (apresentação das personagens e/ou do cenário e/ou da época), desenvolvimento (desenrolar dos fatos apresentando complicação), clímax (momento em que a tensão atinge seu auge) e desfecho (arremate da trama).

As partes constituintes do enredo nos lembram a estrutura clássica do drama onde todas as partes se ligam entre si para que se componha a causalidade e para que haja compreensão total do que é colocado em cena. Há inclusive quem diga que a estrutura engendrada na peça se assemelhe à estrutura da pièce bien faite, cuja construção obedece às leis da causalidade e

\footnotetext{
${ }^{127}$ Esses diálogos truncados e evasivos lembram bastante aqueles que encontramos no teatro do absurdo. Enquanto uma personagem fala sobre a possível morte do filho, outro fala sobre tabaco, por exemplo.
} 
temporalidade, na qual cada acontecimento causa o que vem depois. $O$ conceito da peça bem-feita foi criado e desenvolvido pelo dramaturgo francês Eugene Scribe (1791-1861) e pode ser definido da seguinte forma:

"Trata-se de uma espécie de cartilha do bem- escrever para o teatro, muito de acordo com o ideário normativo cientificista. A base de seus postulados é de origem clássica, convertidos num receituário de aplicação mecânica." 128

Contudo, a estrutura Greco-Ibseniana identificável na peça é um elemento que faz não somente que o enredo avance, mas, que um efeito maior seja alcançado (efeito este completamente diferente do alcançado com peças bem-feitas). Este efeito, alcançado pela relação dialética entre forma e conteúdo, justifica o uso que Miller faz do passado em All My Sons, cujo tema revolve a esfera de ações e consequências.

Analisaremos adiante partes do enredo que ajudam a compreender esta dialética e que trazem à superfície elementos comumente negligenciados por críticos, pesquisadores, leitores e espectadores de texto de teatro.

$\mathrm{Na}$ parte inicial do enredo temos a exposição. Quando a cortina sobe, Joe Keller está sentado lendo seu jornal e logo atrás, à esquerda, encontra-se o doutor Jim Bayliss em pé, que olha para a árvore quebrada. O passado já está presente na forma de imagem (a árvore), mas neste mesmo momento há uma recusa ou talvez descaso com relação a diálogos que possam trazer à tona algo muito forte do passado. Jim Bayliss, que olhava para a árvore quebrada, sequer perguntou dela. A exposição passa a ser feita, portanto, através de diálogos aparentemente triviais que revelam a natureza e a constituição das personagens e colocam gradativamente elementos do passado no presente. Como são inúmeros os exemplos da peça, buscamos selecionar aqueles que ilustram este aspecto de maneira bastante significativa para entender o efeito que a peça apresenta.

\footnotetext{
128 Dicionário do teatro brasileiro: temas, formas e conceitos. J. Guinsburg, João Roberto Faria, Mariangela Alves de Lima, (orgs.). - São Paulo: Perspectiva: SESC São Paulo, 2006, p.235.
} 
O primeiro ato introduzirá as personagens, e para que o enredo avance, elas farão referência ao passado. Basicamente todas elas são apresentadas no primeiro ato por meio de conversas triviais e evasivas, que oscilam entre realidade aparente e realidade oculta. Keller lê o jornal de Domingo e o passado já começa a inundar o presente na forma das próprias personagens que surgem. Os vizinhos Jim e sua esposa Sue; Frank, o astrólogo amador; e Bert, o garoto que brinca de polícia e ladrão com Joe Keller. Frank, por exemplo, vê a árvore quebrada e imediatamente a associa a Larry perguntando a Joe Keller o que Kate, mãe de Larry, dissera sobre a queda da árvore. Bert, o garoto fascinado com a história de brincar de polícia e ladrão, pede para ver a cadeia que Joe Keller disse estar no porão de sua casa.

Chris Keller, filho de Joe e Kate, entra em cena para confessar ao pai que tem interesse em se casar com Ann Deever (antiga vizinha e filha de Steve Deever, ex-funcionário de Joe Keller). Nas primeiras falas de Chris já temos uma pista de que a esfera privada e íntima das personagens está submetida ao peso do passado, e Chris parece ter consciência de que é preciso aceitá-lo, pois quanto maior o retardamento em enxergar a realidade, maior será o impacto posteriormente. Ao confessar que quer casar-se com Ann, ele mostra acreditar que o irmão está morto. A conversa sobre o paradeiro de Larry é exposta em termos claros:

CHRIS: For God's sake, three years. Nobody comes back after three years. It's insane. $(p .15)^{129}$

KELLER: To you and to me. But not to her. You can talk yourself blue in the face, but there's no body and there's no grave, so where are you? (p.15) ${ }^{130}$

A praticidade de Keller o leva à conclusão de que conhece o modo como os outros enxergam as coisas: Keller sabe que sem provas materiais o fato, mesmo que evidente, não pode ser comprovado e assim a ilusão de que o filho

\footnotetext{
${ }^{129}$ [CHRIS: Pelo amor de Deus, três anos. Ninguém volta depois de três anos. É insano.]

130 [KELLER: Para você e para mim. Mas não para ela. Você pode falar o quanto quiser, mas não há corpo e não há túmulo. E então?]
} 
esteja vivo pode ser mantida. $O$ embate entre pai e filho, que parece pertencente ao campo subjetivo e privado, revela que há algo mais profundo, objetivo e coletivo, na crítica que o filho faz a seu pai:

CHRIS: Sometimes you infuriate me, you know that? Isn't it your business too, if I tell this to Mother and she throws a fit about it? You have such a talent for ignoring things. (p.16). ${ }^{131}$

Miller parece habilidosamente seguir os passos de Ibsen, que mostrava que o âmago da aparente intriga de nível pessoal está alicerçado em outros fatores. Esta fala de Chris não é desmentida por Keller, que diz categoricamente:

KELLER: I ignore what I gotta ignore. $\left(\right.$ p.16) ${ }^{132}$

Quando Chris ameaça ir embora e começar uma nova vida, Keller reage de maneira a revelar tanto sua natureza quanto o que a condicionou:

KELLER: You've got business here, what the hell is this? $(p .17)^{133}$

Business é, definitivamente, a força motriz de todo o enredo da peça. Foram os negócios que ajudaram a moldar a personalidade e as ações de Joe, bem como as consequências de seus atos. Kate, suspeitando do pedido de casamento, avisa ao marido que ninguém poderá tirar a fé de Ann (de que um dia Larry voltará) e uma vez mais aponta a coincidência da chegada da moça com a queda da árvore plantada em homenagem ao filho. A superstição de Kate, que atribui sua própria culpa ao destino e às coincidências, é um

${ }^{131}$ [CHRIS: Às vezes você me deixa furioso, sabia? Não é da sua conta também se eu contar à Mãe e ela ficar brava? Você tem um talento tão grande para ignorar as coisas.]

${ }_{132}^{132}$ [KELLER: Eu ignoro o que eu preciso ignorar.]

${ }^{133}$ [KELLER: Você tem negócios aqui. Que diabos é isto?] 
elemento que será brutalmente esmagado pelo peso da realidade. Kate sabe que é culpada por conivência, mas insiste em acreditar que tudo dará certo e que o crime de Joe não atingira o próprio filho:

MOTHER: You above all have got to believe, you... (p.23) ${ }^{134}$
KELLER [rises]: Why me above all? $(\mathrm{p} .23)^{135}$
MOTHER: Just don't stop believing... $(\mathrm{p} .23)^{136}$
KELLER: What does that mean, me above all? $(\mathrm{p} .23)^{137}$

Este trecho caracteriza fortemente a dinâmica de evasão de toda a peça. Kate, a mãe, crê firmemente que o filho ainda esteja vivo, mas, para que sua fé se mantenha é preciso submetê-la à ilusão do presente e não levar em conta o que se passou no passado. Quando ela diz ao marido que ele, acima de todos, precisa acreditar, é um momento em que o passado está verbalizado e fincado brutalmente no presente, mas é "atropelado" por Ann, que muda de assunto. $O$ enredo avança com Keller se defendendo e honrando sua imagem perante a comunidade. Em referência à atitude dos vizinhos quando fora acusado de ter assassino, Joe explica:

KELLER: (...) All the ones who yelled murderer takin' my money now. (p.30) $)^{138}$

Keller deixa explícito que o dinheiro também pode moldar as relações sociais e em seguida revela sua estratégia para reconquistar sua posição de respeito na sociedade. Além disso, a relação que o dinheiro estabelece pode facilmente apagar qualquer lembrança indesejável. Gore Vidal cunha o termo

\footnotetext{
${ }^{134}$ [MÃE: Você, mais que todos, precisa acreditar... você.]

135 [KELLER [levanta]: Por que eu, mais que todos?]

${ }^{136}$ [MÃE: Só não pare de acreditar...]

137 [KELLER: O que significa, eu mais do que todos?]

138 [KELLER: (...) Todos os que gritaram assassino estão pegando meu dinheiro agora.]
} 
"United States of Amnesia ${ }^{139 "}$ em alusão ao processo de apagamento da história no qual a nação está fundada e Keller se mostra bastante consciente disso ${ }^{140}$. Mais como uma (auto) justificativa do que como uma simples explicação, Joe Keller prossegue dizendo:

KELLER: Listen, you do like I did and you'll be all right. The day I come home, I got out of my car;--but not in front of the house ... on the corner. You should've been here, Annie, and you too, Chris; you'd-a seen something. Everybody knew I was getting out that day; the porches were loaded. Picture it now; none of them believed I was innocent. The story was, I pulled a fast one getting myself exonerated. So I get out of my car, and I walk down the street. But very slow. And with a smile. The beast! I was the beast; the guy who sold cracked cylinder heads to the Army Air Force; the guy who made twenty-one P40's crash in Australia. Kid, walkin' down the street that day I was guilty as hell. Except I wasn't, and there was a court paper in my pocket to prove I wasn't, and I walked . . . past ... the porches. Result? Fourteen months later I had one of the best shops in the state again, a respected man again; bigger than ever.(p.30) $)^{141}$

CHRIS [with admiration]: Joe McGuts. (p.30) $)^{142}$

KELLER [now with great force]: That's the only way you lick 'em is guts! $(\text { p. } 30)^{143}$

Keller coloca seu orgulho como sendo a razão de seu triunfo sobre as "injustas" pessoas que o julgaram. A sustentação de seu orgulho está apoiada no documento que provava que ele era inocente. Ele mesmo admite que no dia em que saíra da prisão, ao descer a rua, se sentiu imensamente culpado, mas, sua consciência fora comprada por um pedaço de papel que garantia sua

\footnotetext{
${ }^{139}$ VIDAL, Gore. Imperial America: reflections on the United States of Amnesia. New York: Nation Books, 2004.

${ }^{140}$ Certamente a questão da amnésia e/ou apagamento da história não se limita à questão geográfica. Nações consciente e deliberadamente apagam processos históricos ao "sabor" da ideologia que defendem. ${ }^{141}$ [KELLER: Escute, faça como eu fiz e você ficará bem. No dia que eu cheguei em casa, eu saí do carro; - mas não na frente de casa... na esquina. Você deveria ter estado aqui, Annie, e você também, Chris; vocês teriam visto uma cena. Todos sabiam que eu ía sair aquele dia; as varandas estavam lotadas. Imagine só: nenhum deles acreditava que eu era inocente. A história era, eu havia enganado todo mundo para ser exonerado. Então eu saio do meu carro, e desço a rua. Mas muito devagar. E com um sorriso. A besta! Eu era a besta; o cara que vendera cabeças de cilindro defeituosas para a aeronáutica, o cara que fez com que vinte e um P-40 caíssem na Austrália. Olha, descendo a rua aquele dia eu era certamente culpado. Entretanto, eu não era, e havia um papel do tribunal no meu bolso para provar que eu não era, e eu andei... passei... pelas varandas. Resultado? Quatorze meses depois eu tinha uma das melhores lojas do estado novamente, um homem respeitado novamente; maior do que nunca.]

${ }^{142}$ [CHRIS (com admiração): Joe, o "Corajoso".]

143 [KELLER (agora com grande força): Essa é a única maneira de triunfar sobre eles... coragem.]
} 
inocência. Certamente esta fala ignora o fato de o papel ter sido conseguido às custas de responsabilizar uma outra pessoa, mas, em uma sociedade em que o capitalismo é a palavra de ordem, é muito mais importante ter do que ser.

A questão da responsabilidade é explorada fortemente já neste ato, mas está focada no suposto culpado, Steve Deever. Joe Keller pede a Chris e Ann que não condenem Steve, principalmente sua filha. Sua visão fragmentada sobre responsabilidade social é logo rebatida por Chris:

KELLER: (...) [to Ann] Those cylinder heads went into P-40's only. What's the matter with you? You know Larry never flew a P-40. ${ }^{144}$

CHRIS: So who flew those P-40's, Pigs? ${ }^{145}$

Keller não enxerga conexão viável entre seu ato passado e consequências no presente e o enredo vai ganhando ação com as constantes colisões entre personagens que apresentam esta fratura entre passado e presente. Keller explica o que aconteceu na noite em que o crime fora cometido, mas, seu tom é de compreensão e entendimento (até mesmo de compaixão) para com o assassino (ele mesmo). Keller chega a modalizar seu discurso de uma tal forma que o crime soa como um evento casual e completamente justificável:

KELLER: The man was a fool, but don't make a murderer out of him. You got no sense? Look what it does to her! [to Ann] Listen, you gotta appreciate what was doin' in that shop in the war. The both of you! It was a madhouse. Every half hour the Major callin' for cylinder heads, they were whippin' us with the telephone. The trucks were hauling them away hot, damn near. I mean just try to see it human, see it human. All of a sudden a batch comes out with a crack. That happens, that's the business. A fine, hairline crack. All right, so...so he's a little man, your father, always scared of loud voices. What'll the Major say? Half a day's production shot... What'll I say? You know what I mean? Human. [he

\footnotetext{
${ }^{144}$ [KELLER: (...) [para Ann] Aquelas cabeças de cilindro foram somente para os P-40. O que há com você? Você sabe que o Larry nunca pilotou um P-40!]

${ }^{145}$ [CHRIS: Então, quem pilotou aqueles P-40, Porcos?]
} 
pauses] So he takes out his tools and he ... covers over the cracks. Alright, that's bad, it's wrong, but that's what a little man does. If I could have gone in that day l'd a told him... Junk 'em Steve, we can afford it. But alone he was afraid. But I know he meant no harm. He believed they'd hold up a hundred percent. That's a mistake, but it ain't murder. You mustn't feel that way about him. You understand me? It ain't right. (p.32-3) ${ }^{146}$

Nesta tentativa de desculpar as ações de "Steve", Joe Keller faz uma defesa de seu tão amado e sagrado business explicando que Steve, por ser um "little man", teve medo das vozes dos mais altos. Abdicar dos ganhos gigantescos durante a guerra seria loucura, portanto, mesmo sendo um erro, não significa que Steve seja um assassino, segundo a mentalidade de Keller. O assunto, que poderia levar a reflexões mais profundas sobre o sentido do lucro em tempos de guerra, é interrompido quando Keller pergunta se Ann aguentaria comer um Steak e tomar Champagne. É neste clima "festivo" que Chris decide pedir a mão de Ann em casamento. Keller tenta novamente convencer o filho a ficar com os negócios criados por ele:

KELLER: [with a great force, moving about] I want a clean start for you, Chris. I want a new sign over the plant - Christopher Keller, Incorporated. (p.38) ${ }^{147}$

Talvez como um modo de negociar com o filho, Keller propõe dar à empresa o nome 'Christopher Keller'. Aqui podemos ver novamente a insistência de Keller em querer algo escrito, algo que prove visualmente que

\footnotetext{
${ }^{146}$ [KELLER: O cara era um tolo, mas não transforme ele em assassino. Você não tem descência? Veja o que isso faz com ela! [para Ann] Escute, você precisa prezar o que estava sendo feito na loja durante a guerra. Vocês dois! Era uma loucura. A cada meia hora o prefeito ligando por causa das cabeças de cilindro, eles estavam nos chicoteando com o telefone. Os caminhões estavam levando-as embora quase que quentes. Eu quero dizer, somente tentem enxergar de maneira humana, enxerguem humanamente. De repente uma remessa sai com uma rachadura. Isso acontece, isto são os negócios. Uma pequena, minúscula rachadura. Tudo bem, então... ele é um homem pequeno, o seu pai, sempre com medo das vozes mais altas. O que o prefeito dirá? Metade da produção do dia por água abaixo... O que eu vou dizer? Está entendendo o que eu quero dizer? Humanamente. (ele pausa) Então ele pega suas ferramentas e ele... cobre os buracos.Tudo bem, isto é ruim, isto é errado, mas é isto que um homem pequeno faz. Se eu pudesse ter ído naquele dia, eu teria dito a ele... Jogue-os fora, Steve, a gente consegue pagar. Mas sozinho ele estava com medo. Mas eu sei que ele não fez por mal. Ele achava que os cilindros funcionariam sem problemas. Isso é um erro, mas não é assassinato. Vocês não deveriam se sentir assim em relação a ele. Vocês entendem? Não é certo.]

${ }^{147}$ [KELLER: (com grande força, movendo-se) Eu quero um novo início para você, Chris. Eu quero uma nova placa em cima da loja - Christopher Keller, S.A.]
} 
Chris esteja realmente ligado ao empreendimento. Assim como o evento de sua saída da prisão exigiria um documento escrito que provasse o contrário, de maneira similar Keller entende que Chris, tendo o nome estampado na empresa, pode esquecer toda a culpa que sente em relação ao dinheiro do pai. Além disso, o termo Incorporated carrega um significado interessante: ele expressa exatamente a condição de Joe Keller. O termo que remete à 'corporação', nos lembra Iná Camargo Costa ${ }^{148}$, não adquire somente o sentido literal, mas, o conceito de um homem que se torna uma função de produção ou distribuição ao ponto de sua personalidade separar-se da ação que ela impulsiona.

O enredo começa a apresentar a complicação com a vinda de George (irmão de Ann), anunciada por telefone um pouco depois. Tal fato prenuncia que o presente esconde certos segredos e Kate, consciente do que se passa exatamente, avisa o marido:

MOTHER: Be smart now, Joe. The boy is coming. Be smart. (p.40) $)^{149}$

Algo meio sombrio, representado inclusive cenograficamente pela luz (analisado no item das rubricas) já paira no ar, e nós o detectamos na conversa entre Sue, esposa de Jim, e Ann. Ficamos sabendo a verdade escancarada: todos sabem e comentam que Joe Keller foi esperto e conseguiu sair da cadeia. Curiosamente o modo como as pessoas agem com os Keller contradiz fundamentalmente a opinião que estas mesmas pessoas têm deles. Joe continua mantendo-se como um vencedor que pode acolher os mais desfavorecidos e chega inclusive a dizer à Ann que dará um emprego a seu pai. Joe Keller está, na realidade, procurando sedimentar o presente com perspectivas de futuro e as promessas do American Dream. Contudo, já vemos na fala de Jim, que fora buscar George na estação, um tom de aviso:

\footnotetext{
${ }^{148}$ COSTA, Iná.C. Panorama do Rio Vermelho: ensaios sobre o teatro americano moderno. op.cit., p.11.

149 [MÃE: Seja esperto agora, Joe. O garoto está vindo. Seja esperto.]
} 
JIM: You know why he's here, don't try to kid it away. (p.51) 150

Isto atesta o que Sue dissera anteriormente sobre as pessoas saberem e comentarem que Joe Keller tem a ver com o crime muito mais do que Steve Deever. O enredo, até então, mostra abertamente que o solo que sedimenta 0 presente não é exatamente aquele que vemos em cena. A atmosfera informal e descontraída, o cenário familiar e amigável e o comportamento das personagens externalizam um momento que oculta muitas coisas. Com a chegada de George, o clima de animosidade aumenta e a atmosfera ganha diálogos mais densos e tom acusativo. Chris procura desautorizar George ao achar sua atitude (em acusar Keller e defender seu pai) muito infantil, chamando-o inclusive de 'boy'. O problema de George, segundo Chris, é que ele mergulha demais nas coisas. A crítica que Chris faz a George é exatamente o oposto do que ele faz, daí sua alienação perante a situação do crime. A conversa avança e George revela ao que veio:

GEORGE: (...) Annie, you don't know what was done to that man. You don't know what happened. $(p .54)^{151}$

ANN [afraid]: Of course I know. (p.54) ${ }^{152}$

GEORGE: You can't know, you wouldn't be here. Dad came to work that day. The night foreman came to him and showed him the cylinder heads... they were coming out of the process with defects. There was something wrong with the process. So Dad went directly to the phone and called here and told Joe to come down right away. But the morning passed. No sign of Joe. So Dad called again. By this time he had over a hundred defectives. The Army was screaming for stuff and Dad didn't have anything to ship. So Joe told him... on the phone he told him to weld, cover up the cracks in any way he could, and ship them out. (p.54) ${ }^{153}$

\footnotetext{
${ }^{150}$ [JIM: Você sabe porque ele está aqui, não finja que não sabe.]

${ }^{151}$ [GEORGE: Annie, você não sabe o que foi feito com aquele homem. Você não sabe o que aconteceu.] 152 [ANNIE (com medo): Claro que sei.]

153 [GEORGE: Você não deve saber, não estaria aqui. Papai foi trabalhar naquele dia. À noite o mestre de obras veio a ele e lhe mostrou as cabeças de cilindro... elas estavam saindo com defeito. Então, papai foi diretamente ao telefone e ligou para cá e disse para que Joe fosse imediatamente para lá. Mas, a manhã passou. Nenhum sinal de Joe. Então papai ligou de novo. A essa hora ele tinha mais de cem peças defeituosas. A aeronáutica estava 'gritando'por coisas e papai não tinha nada para mandar. Então Joe
} 
Aqui está a revelação do que acontecera no dia do crime, segundo a versão de George. Chris tenta interrompê-lo, mas, sua tentativa é frustrada pela persistência do irmão de Ann:

CHRIS: Are you through now? (p.54) 154

GEORGE: (surging up at him) I'm not through now! Dad was afraid. He wanted Joe there if he was going to do it. But Joe can't come down....He's sick. Sick! He suddenly gets the flu! Suddenly! But he promised to take responsibility. Do you understand what I'm saying? On the telephone you can't have responsibility! In a court you can always deny a phone call and that's exactly what he did. They knew he was a liar the first time, but in the appeal they believed that rotten lie and now Joe is a big shot and your father is the patsy.[He gets up] Now what're you going to do? Eat his food, sleep in his bed? Answer me: what're you going to do? (p.54-5) 155

Chris e Ann seguem se recusando a aceitar o que acabara de ser dito por George, e a tensão do enredo vai aumentando cada vez mais. Ainda não satisfeito com a reação dos dois, George aprofunda seu raciocínio explicitando não somente aquilo que está manifesto, mas sim latente na ação de Joe Keller:

GEORGE: And he's the kind of boss to let a hundred and twenty one cylinder heads be repaired and shipped out of his shop without even knowing it?

$(\mathrm{p} .55)^{156}$

CHRIS: He's that kind of boss. (p.55) $)^{157}$

\footnotetext{
disse a ele... no telefone ele disse a ele para soldar, cobrir as rachaduras do modo que pudesse e mandálas.]

154 [CHRIS: Você já terminou?]

155 [GEORGE: (indo em sua direção) Eu ainda não terminei! Papai estava com medo. Ele queria o Joe lá, caso ele fosse fazer isso. Mas, Joe não pode ir... ele está doente. Doente! Ele de repente fica gripado! De repente! Mas ele prometeu assumir a responsabilidade. Você entende o que eu estou dizendo? No telefone você não pode ter responsabilidade! No tribunal você sempre pode negar uma ligação e foi exatamente isso que ele fez. Eles sabiam que ele era um mentiroso desde o começo, mas no recurso eles acreditaram na mentira podre e agora Joe é o grande manipulador e o seu pai é o bode espiatório. (Ele se levanta) E o que você vai fazer agora? Comer sua comida, deitar na sua cama? Me responda: o que você vai fazer?]

${ }^{156}$ [GEORGE: E ele é o tipo de chefe que deixa cento e vinte e um cilindros serem consertados e enviados de sua loja sem saber?]

${ }^{157}$ [CHRIS: Ele é esse tipo de chefe.]
} 
GEORGE: And that's the same Joe Keller who never left his shop without first going around to see that all the lights were out. (p.55) ${ }^{158}$

CHRIS: (with growing anger) The same Joe Keller. (p.55) ${ }^{159}$ GEORGE: The same man who knows how many minutes a day his workers spend in the toilet. (p.55) ${ }^{160}$

CHRIS: The same man. (p.55) ${ }^{161}$

GEORGE: And my father, that frightened mouse who'd never buy a shirt without somebody along... That man would do such a thing on his own? (p.56) ${ }^{162}$

Quando Kate entra em cena, ficamos sabendo que George sempre gostou dela, afinal, o papel de Kate na peça é descrito pelo nome que ela recebe: "Mãe". Desempenhando sua função principal, Kate faz elogios e críticas à aparência e ao estilo de vida de George e um comentário aparentemente corriqueiro revela mais do que o sentido literal do que pretendia dizer:

MOTHER: I'm sick to look at you. What's the matter with your mother, why don't she feed you? (p.58) ${ }^{163}$

ANN: He just hasn't any appetite. (p.58) $)^{164}$

MOTHER: If he ate in my house he'd have an appetite. $(p .58)^{165}$

\footnotetext{
${ }^{158}$ [GEORGE: E esse é o mesmo Joe Keller que nunca saiu de sua loja sem primeiro verificar se todas as luzes foram desligadas.]

${ }^{159}$ [CHRIS: (com uma raiva crescente) O mesmo Joe Keller.]

160 [GEORGE: O mesmo homem que sabe quantos minutos por dia seus funcionários gastam no banheiro.]

${ }^{161}$ [CHRIS: O mesmo homem.]

162 [GEORGE: E o meu pai, aquele rato assustado, que jamais compraria uma camisa sem ter alguém junto... Aquele homem faria tal coisa sozinho?]

${ }^{163}$ [MOTHER: Cansei de olhar para você. O que há de errado com a sua mãe, por que ela não te alimenta?]

${ }^{164}$ [ANN: Ele simplesmente não tem apetite algum.]

${ }^{165}$ [MOTHER: Se ele comesse na minha casa ele teria apetite.]
} 
Certamente o apetite dos Keller é algo que não pode ser contestado. A "fome" por ganhar dinheiro e por ser um vencedor levou a família à condição trágica. O clima maternal continua e leva a cena para um clima descontraído, e o faz com um tom de humor que busca suavizar a tensão:

CHRIS: She could turn Mahatma Gandhi into a heavy weight. (p.58) ${ }^{167}$

Tal tom começa a tomar outros rumos quando o assunto é Steve Deever. Joe Keller insiste que George deve falar sobre o assunto e pede a Chris que não interfira. Embora fique claro, aqui, que o mecanismo de evasão é algo do qual Keller tem consciência, ele não permite que essa evasão ocorra neste momento, porque tentará manipular o que virá adiante. Keller primeiramente mostra-se compadecido pela situação de seu ex-funcionário, e quando recebe como resposta de George uma ação não-verbal, tenta comprar o filho de Steve logo em seguida:

KELLER: (...) That's the way they do, George. A little man makes a mistake and they hang him by the thumbs; the big ones become ambassadors. I wish you'd told me you were going to see Dad. (p.63) ${ }^{168}$

GEORGE [studying him]: I didn't know you were interested. (p.63) ${ }^{169}$

KELLER: In a way, I am. I would like him to know, George, that as far as I'm concerned, any time he wants, he's got a place with me. I would like him to know that. $(p .63)^{170}$

\footnotetext{
${ }^{166}$ Esta "fome" por ganhar dinheiro e por ser um vencedor (remanescência do American Dream) será brilhantemente explorada em sua peça seguinte: Death of a Salesman, 1949.

${ }^{167}$ [CHRIS: Ela poderia transformar Mahatma Gandhi em um peso-pesado.]

168 [KELLER: É isso que eles fazem, George. Um homem pequeno comete um erro e eles querem crucificá-lo; os grandes se tornam embaixadores. Eu queria que você tivesse me dito que você ía ver o seu pai.]

${ }^{169}$ [GEORGE: (analisando-o) Eu não sabia que você estava interessado.]
} 
Keller se mostra compreensivo e solidário, dizendo a George que é injusto o que fora feito com seu pai. Ao receber o "olhar analítico" do garoto, que desmente ou questiona o que acabara de ser dito (ao "estudá-lo"), Keller usa uma estratégia que não somente busca "comprar" George, como livrá-lo de sua culpa em relação à condenação de seu ex-funcionário.

O desenvolvimento do enredo começa a atingir seu clímax no momento em que Kate deixa escapar que o marido jamais estivera doente nos últimos anos quinze anos. A evasão entra novamente como um recurso que visa diminuir a tensão com uma última interferência de Frank, o vizinho, que aparece com o mapa astral de Larry. Kate tenta estender a conversa para desviar o foco:

FRANK: (...) I've got something amazing for you, Kate, I finished Larry's horoscope. (p.66) $)^{171}$

MOTHER: You'd be interested in this, George. It's wonderful the way he can understand the... (p.66) $)^{172}$

Chris entra e se revolta com a atitude de Frank em incentivar Kate a acreditar que Larry esteja vivo somente porque o dia em que ele supostamente morreu havia sido, também, seu "Dia Favorável". O horóscopo tem um papel importante na peça e naquilo que ela mostra, pois funciona como uma última tentativa de contradizer os sinais que haviam se apresentado anteriormente. Em outras palavras, este gesto é a última "tentação da inocência", que inevitavelmente levará ao fracasso. O próprio Miller pensou em chamar a peça

\footnotetext{
${ }^{170}$ [KELLER: De certa forma, eu estou. Eu gostaria que ele soubesse, George, que se depender de mim, a hora que ele quiser, ele tem um lugar comigo. Eu gostaria que ele soubesse disso.]

${ }_{171}$ [FRANK: (...) Eu tenho uma coisa maravilhosa para você, Kate. Eu terminei o horóscopo de Larry.]

172 [MÃE: Você ficaria interessado nisso, George. É maravilhoso o jeito que ele consegue entender o...]
} 
de 'The Sign of the Archer', sendo que Archer é uma referência ao arqueiro, signo de Sagitário. Em dado momento Kate diz que tudo já está prédeterminado desde quando nascemos. A ideia que se mostra como uma estratégia para responsabilizar o destino (assim como fazia a tragédia grega) se contrapõe de maneira categórica à noção de destino da tragédia moderna que coloca o destino como o resultado direto de ações individuais, que terão reflexo no coletivo e vice-versa.

Miller, contudo, escolhe outro título para a peça que remete à dimensão real (simultaneamente privada e coletiva) e não à metafísica. Frank, aquele que aparentemente crê no poder dos astros, sai de cena com os agradecimentos de Kate por ter reacendido a esperança de que Larry esteja vivo.

Com a verdade cravada no presente e com a ameaça de Chris casarse com Ann, Kate como último recurso para sua defesa se vê obrigada a utilizar a verdade:

MOTHER: Your brother's alive, darling, because if he's dead, your father killed him. Do you understand me now? As long as you live, that boy is alive. God does not let a son be killed by his father. Now you see, don't you? Now you see. [Beyond control, she hurries up and into the house.] (p.68) ${ }^{173}$

Esta revelação é bastante direta e mostra que Kate tem consciência de que $o$ ato individual de Joe se estende a ponto de afetar o coletivo. Ainda assim, Kate apresenta um fio de esperança baseado na religião "Deus não permite que um filho seja morto pelo pai" para que não aceite toda a verdade. A discussão que se segue entre Chris e seu pai mostra que Keller não enxerga a conexão entre seu ato individual e o reflexo do mesmo no coletivo. Ele se vê conectado ao contexto imediato e somente fez o que "deveria ser feito". Os

\footnotetext{
${ }^{173}$ [MOTHER: Seu irmão está vivo, querido, porque se ele estiver morto, seu pai o matou. Você me entende agora? Enquanto você viver, aquele menino está vivo. Deus não permite que um filho seja morto pelo seu pai. Agora você entende, não é? Agora você entende (fora de controle, ela corre e entra na casa).]
} 
tempos eram de guerra e ele precisava ganhar dinheiro, não havendo, assim, tempo para falhas:

KELLER: It was too late. The paper, it was all over the front page, twenty one went down, it was too late. They came with handcuffs into the shop, what could I do? [He sits on bench] Chris... Chris, I did it for you, it was a chance and I took it for you. I'm sixty one years old, when would I have another chance to make something for you? Sixty one years old you don't get another chance, do ya?

KELLER: For you, a business for you! (p.70) ${ }^{175}$

Keller assume sua responsabilidade em ter consentido com o envio das peças defeituosas, mas não assume sua culpa. Explica a Chris que não fizera por mal, mas, sim porque precisava ganhar dinheiro e sustentar os negócios. Este ponto merece um paralelo com o pensamento da filósofa alemã Hannah Arendt. Sócrates, via Platão (em A República, Livro IX), defende que $O$ homem que pratica o mal é o mais infeliz e escravizado de todos, pois vive amarrado a medos, inseguranças, instabilidade e à sua própria consciência, sendo que ele deve consigo mesmo. Hannah Arendt, todavia, parece estar mais próxima da realidade escancarada por Joe Keller, quando diz:

Tenho certeza de que os maiores males que conhecemos não se devem àquele que tem de confrontar-se consigo mesmo de novo, e cuja maldição é não poder esquecer. Os maiores malfeitores são aqueles que não se lembram porque nunca pensaram na questão. ${ }^{176}$

Hannah Arendt postula e aprofunda este conceito sob o título de 'banalidade do mal', dentro do qual diz que o mal é muitas vezes praticado de

\footnotetext{
${ }^{174}$ [KELLER: Era tarde demais. O jornal, estava na página principal inteira, vinte e um caíram, era tarde demais. Eles vieram com algemas na loja, o que eu poderia fazer? (ele senta no banco) Chris, eu fiz isso por você, era uma chance e eu a arriquei por você. Eu tenho sessenta e um anos, quando eu teria uma outra chance de fazer algo por você? Com sessenta e um anos não se consegue uma outra chance, não é?] 175 [KELLER: Por você, um negócio por você.]

176 ARENDT, Hannah. Algumas Questões de Filosofia Moral. In: Arendt, H. Responsabilidade e Julgamento.Trad. Rosaura Eichenberg. São Paulo: Companhia das Letras, 2004, p.159.
} 
forma burocrática e mecânica. Seu livro 'Eichmann em Jerusalém ${ }^{177}$ ' conclui que o oficial nazista não possuía um histórico ou traços antisemitas e não apresentava características de uma pessoa com caráter distorcido ou doentio. Ele agiu como agiu por desejo de ascender em sua carreira profissional e seus atos foram resultados do cumprimento de ordens superiores. Eichmann, para Arendt, era um burocrata que cumpria ordens sem refletir sobre as consequências. Para ele tudo era realizado com zelo e eficiência, e não havia nele o sentimento de "bem" ou "mal" em seus atos. Joe Keller é a personagem que em grande medida se aproxima da imagem de Eichmann: um indivíduo que não enxerga conexão de seus atos individuais como refletidos no coletivo. Assim como Joe Keller o faz, Peter Stockmann, em An Enemy of the People (como veremos adiante) também acredita no cumprimento de ordens para justificar atos. O prefeito da cidade tenta convencer Dr.Stockmann a dissociar suas convicções pessoais das profissionais, buscando justificar, assim, a necessidade em acatar ordens sem ter a necessidade de se pensar no impacto delas. Miller, contudo, demonstra que as palavras de Chris não parecem resultar daquele cumprimento de ordens que revela 0 sentido de culpa/responsabilidade que o havia atormentado. Enquanto andava pelas ruas, Chris perguntava-se o que havia por detrás daquela quietude e paz:

CHRIS: [with burning fury] For me! Where do you live, where have you come from? For me! ...I was dying every day and you were killing my boys and you did it for me? What the hell do you think I was thinking of, the Goddam business? Is that as far as your mind can see, the business? What is that, the world of business? What the hell do you mean, you did it for me? Don't you have a country? Don't you live in the world? What the hell are you? You're not even an animal, no animal kills his own, what are you? What must I do to you? I

ought to tear the tongue out of your mouth, what must I do? [With his fist he pounds down upon his father's shoulder. He stumbles away, covering his face as he weeps] What must I do, Jesus God, what must I do? (p.70-71) ${ }^{178}$

\footnotetext{
${ }^{177}$ ARENDT, Hannah. Eichmann em Jerusalém. São Paulo: Companhia das Letras, 1999.

${ }^{178}$ [CHRIS (com fúria crescente): Por mim! Onde você vive? De onde você vem? Por mim! Eu estava morrendo a cada dia e você estava matando os meus amigos e você fez isso por mim? Que diabos você acha que eu pensava, nos malditos negócios? É até aí que o seu raciocínio consegue chegar? O que é isso, o mundo dos negócios? Que diabos você quer dizer que fez isso por mim? Você não tem um país? Não vive no mundo? Que diabos é você? Você não é nem mesmo um animal, um animal não mata sua própria espécie, o que você é? O que eu devo fazer com você? Eu tenho que arrancar a língua da sua boca, o que eu devo fazer? (com seu punho ele esmurra o ombro de seu pai. Ele tropeça, cobrindo seu rosto enquanto chora) O que eu devo fazer, meu Deus, o que eu devo fazer?]
} 
Esta fala de Chris critica e questiona a máxima maquiavélica de que "os fins justificam os meios" tão comum à raça humana, de maneira geral. Sua indignação é que seu pai não compreende que é, de fato, culpado. Seu sagrado business, feito na esfera individual, não pode ter impacto na vida de outrem, segundo sua mentalidade. Sua "fome" por lucro e pelo bem-estar de sua família o levou a agir de tal forma, com o respaldo da filosofia do momento que era a de lutar e apoiar o país nos esforços de guerra. Sua condição de homem comum o tornou não somente criminoso, mas também, de certa forma, vítima de um sistema que sugere que não ter lucro (ou ter um lucro baixo) não garante plena felicidade. A sociedade da qual Joe Keller faz parte é uma sociedade em que é necessário "ter" para "ser". Quando Chris aponta as consequências de suas ações a ele, as consequências das ações do passado são mais impactantes e vivas do que as próprias ações do presente. É esta compreensão de que o presente não é um momento isolado no tempo que confere completa e absoluta conscientização de que a técnica analítica funciona como um mecanismo simultaneamente elucidador e não-alienante.

A discussão entre Joe Keller e sua esposa sobre a aceitação da responsabilidade/culpa explicita que Miller busca não moralizar, mas despertar a consciência. Ao mostrar que nenhum dos dois não entendeu que a questão da culpa não é um comportamento a ser adquirido, mas um sentimento que precisa ser compreendido, vemos:

MOTHER: You want to live? You better figure out your life. $(p .75)^{179}$ MOTHER: I mean if you told him that you want to pay for what you did. $(p .76)^{180}$ KELLER: [sensing...quietly]: How can I pay? (p.76) ${ }^{181}$ MOTHER: Tell him you're willing to go to prison. [pause] (p.76) ${ }^{182}$

\footnotetext{
${ }^{179}$ [MÃE: Você quer viver? É melhor você descobrir um jeito.]

${ }^{180}$ [MÃE: Eu quero dizer, se você dissesse a ele que você quer pagar pelo que fez.]

181 [KELLER: (percebendo, silenciosamente) Como eu posso pagar?]

182 [MÃE: Diga a ele que você está disposto a ir para a prisão. (pausa)]
} 
KELLER [struck, amazed]: I'm willing to...? (p.76) $)^{183}$

MOTHER [quickly]: You wouldn't go, he wouldn't ask you to go. But if you told him you wanted to, if he could feel that you wanted to pay, maybe he would forgive you. (p.76) ${ }^{184}$

Para Kate, a questão pode ser resolvida com o perdão de Chris, mas, para isto é necessário que o pai se mostre arrependido. Em uma sociedade que privilegia a imagem e o espetáculo, 0 ato de arrependimento precisa ser feito. Kate sugere uma estratégia, pois sabe que o filho provavelmente não deixará que Keller vá à prisão. Keller, contudo, ainda não enxerga culpa alguma e muito menos a necessidade de ser perdoado:

KELLER: I don't know what you mean! You wanted money, so I made money. What must I be forgiven? You wanted money, didn't you? (p.76) ${ }^{185}$

Kate diz que "fazer dinheiro" para a família não desculpa o que ele fez, e diz que para Chris há algo maior que a família (em referência à responsabilidade social). Joe ainda justifica que qualquer coisa que seu filho fizesse seria perdoado, pois Chris é seu filho, assim como Keller é pai de Chris:

KELLER: I'm his father and he's my son and if there's something bigger than that I'll put a bullet in my head! (p.77) ${ }^{186}$

E novamente deixa claro seu entendimento do mundo e seu funcionamento:

\footnotetext{
183 [KELLER: (impressionado e espantado) Eu estou disposto a...?]

184 [MÃE: (rapidamente) Você não iria, ele não te pediria para ir. Mas, se você dissesse a ele que você queria, se ele pudesse sentir que você quer pagar, talvez ele poderia te perdoar.]

${ }^{185}$ [KELLER: Eu não entendo o que você quer dizer. Você queria dinheiro, então eu ganhei dinheiro. Do que eu preciso ser perdoado? Você queria dinheiro, não queria?]

${ }^{186}$ [KELLER: Eu sou o pai dele e ele é meu filho, e se há algo maior do que isso, eu vou colocar uma bala na minha cabeça.]
} 
KELLER: Goddam, if Larry was alive he wouldn't act like this. He understood the way the world is made. He listened to me. To him the world had a forty-foot

front, it ended at the building line. This one, everything bothers him. (p.77) ${ }^{187}$

Sua visão limitada espelha novamente a alienação que foi assumida por ele logo no começo da peça quando se declarou "uneducated". Seu desespero em não ser compreendido desestabiliza a honra e o respeito que Joe e seus negócios possuíam (mesmo que somente de fachada). Sua completa despolitização se vê materializada na premissa do "laço de sangue" que, segundo sua mentalidade, deveria ser fonte de união e honra.

Ann pede a Kate que reconheça que seu filho está morto para que possa se casar com Chris. Não vendo saída para a negação extrema de Kate, Ann se utiliza de um recurso bastante comum às tragédias gregas: uma surpresa. Ann revela que Larry bateu o avião no dia vinte e cinco de novembro e que o motor não falhou, mas que ele está morto e mostra uma carta à mãe de Larry. Como mencionamos antes, tal recurso fora criticado por soar artificial. Eric Bentley explica que este é "o acessório consagrado pelo tempo, de todos os melodramas" em que há uma descoberta de uma carta nos últimos minutos em que tudo se revela. Jean Gould, contudo, discorda da opinião de Bentley e diz que $A l l$ My Sons não se encaixa em tal definição, pois é um drama de ideias. $\mathrm{O}$ recurso da carta nos lembra, em grande medida, o lenço de Desdêmona, personagem de Othello, de Shakespeare. Por conta de um simples lenço nas mãos de outro homem, Othello toma como prova que sua esposa o traía e a mata por tal motivo. Na realidade, Desdêmona era inocente, e por trás estava lago e outros, tramando para destruir Othello. A carta, em All My Sons, e o lenço, em Othello, servem como prova final de que o que se supunha estava confirmado e isto faz avançar o enredo. Acreditamos que o elemento, mesmo que soando artificial, ajuda a amarrar o enredo ao "dramatizar" a morte de

\footnotetext{
${ }^{187}$ [KELLER: Maldito seja, se Larry estivesse vivo ele não agiria assim. Ele entendia o jeito que o mundo é feito. Ele me escutava. Para ele o mundo tinha dez por trinta, terminava na linha da calçada. Esse aí tudo o incomoda.]
} 
Larry, e dar a ela uma explicação. O esclarecimento de que ele não morreu por acidente, mas que se matou, afirma com força emocional e racional a questão da responsabilidade. É a carta mais uma peça do quebra-cabeça que se encaixa e define com concretude até que ponto se estendeu o crime de Joe Keller. Sem o recurso, a morte de Larry poderia não ficar totalmente evidente e Miller optou por não deixar dúvidas com relação às circunstâncias ligadas à morte do rapaz. Miller parece, em grande medida, ter atingido com a carta um dos seus objetivos (já mencionado) antes, mas que vale a pena ser reiterado:

I wanted to write a play that would stand on the stage like a boulder that had fallen from the sky, undeniable, a fact. I had come a particular road to the point of making such a demand not only of myself but of the drama. ${ }^{188}$

A carta é um fato, algo inegável que funciona como o atestado de óbito de Larry. Miller, ao saber que uma das críticas à peça se dava pela alegação de que ela havia sido excessivamente tramada ao ponto de ter coincidências implausíveis, responde comparando-a com o mito de Édipo:

If the myth behind Oedipus allows us to stretch our commonsense judgment of its plausibility, the letter's appearance in All My Sons seems to me to spring out of Ann's character and situation and hence is far less difficult to accept than a naked stroke of fate ${ }^{189}$.

Longe de querer criar qualquer recurso artificial, Miller, com a carta, mostra ao público não somente que há surpresas no enredo, mas, que as personagens envolvidas mantinham segredos escondidos que talvez pudessem ser mantidos como tal. Contudo, as consequências das ações passadas na peça são tão inescapáveis que neste momento o passado sufoca qualquer tentativa em mantê-lo na obscuridade. Aliás, a técnica analítica, como nos lembra Szondi em Teoria do Drama Moderno, tem a função de revelar os motivos que estão na origem dos acontecimentos, e para que isso se dê, para

\footnotetext{
${ }^{188}$ MILLER, Arthur. Timebends, op.cit., p.224. [Eu queria escrever uma peça que ficasse no palco como uma pedra que tivesse caído do céu, inegável, um fato. Eu havia chegado em um estágio em que eu precisava exigir isso não somente de mim, mas do drama.]

${ }^{189}$ MILLER, Arthur. Timebends, op.cit., p.134. [Se o mito por trás de Édipo nos permite esticar nosso julgamento do senso comum de sua plausibilidade, a carta em All My Sons parece-me surgir da personalidade e situação de Ann e, portanto, é muito menos difícil de aceitar do que um golpe do destino.
} 
que essa causalidade seja resgatada e explicitada, a carta serve como um elo entre o que se passou para que o que se passa agora seja melhor compreendido.

Chris se vê como culpado por participação indireta nos crimes do pai. Culpa a si mesmo por ter sido covarde quando suspeitou da hipótese de seu pai ter cometido o crime. Sua crítica é à praticidade, ao pensamento imediato e inconsequente de enxergar o presente como um momento isolado, sem reflexos no futuro. Contudo, o presente dos Keller é, nada mais do que a memória e as ações do passado corroendo o momento atual. O peso do passado é tão forte e traumático que os impede de viver o presente como um momento isolado no tempo. A casa, o jardim, os vizinhos, os sonhos (oníricos e não-oníricos), o verbal e o não-verbal etc estão infestados de elementos do passado. T.S Eliot possui uma frase interessante a este respeito quando em seu ensaio seminal "Tradition and Individual Talent ${ }^{190 ", ~ d e ~ 1921, ~ f a l a ~ s o b r e ~}$ "The Pastness of the Present" apontando o quão significativo o passado é dentro do presente e precisa ser levado em conta.

Chris, percebendo que o passado estava escancarado no presente, se diz sem saber o que fazer com o pai:

CHRIS: What? Do I raise the dead when I put him behind bars? Then what'll I do it for? We used to shoot a man who acted like a dog, but honor was real there, you were protecting something. But here? This is the land of the great big dogs, you don't love a man here, you eat him! That's the principle; the only one we live by... it just happened to kill a few people this time, that's all. The world's that way, how can I take it out on him? What sense does that make? This is a zoo, a zoo! (p.81) ${ }^{191}$

\footnotetext{
${ }^{190}$ ELIOT, Thomas Stearns. Tradition and Individual Talent. In: The Sacred Wood. New York: Alfred A. Knopf, 1921.

${ }^{191}$ [CHRIS: O que? Eu ressuscito os mortos ao colocá-lo atrás das grades? Então para que farei isso? A gente constumava atirar em um homem que agia como um cão, mas honra era real lá, você estava protegendo algo. Mas aqui? Esta é a terra dos grandes cães, você não ama um homem aqui, você o devora! Este é o princípio; o único pelo qual vivemos. Aconteceu de matar algumas pessoas desta vez, e isto é tudo. O mundo é deste jeito, como eu posso descontar nele? No que vai ajudar? Isto é um zoológico, um zoológico!]
} 
Chris admite que a questão de se fazer justiça é nada mais do que cumprir um "protocolo". Ao questionar se ele poderia ressuscitar os mortos colocando o pai atrás das grades, Chris fala que o mundo está acostumado com isso, como ele pode descontar no pai? Que sentido teria se o mundo é um zoológico? Tais questionamentos permanecem como uma incógnita por toda a dramaturgia de Miller e assumem, cada vez mais, um caráter existencialista de questionamento da consciência, da culpa e da responsabilidade do ser humano perante suas escolhas, na medida em que Miller amadurece intelectual e dramaturgicamente ${ }^{192}$.

Joe Keller, em conversa com seu filho, continua a se defender e a desculpar seus atos assumindo uma falibilidade que deve ser perdoada a qualquer custo. Chris, que agora segura a carta, prossegue para o último embate com seu pai, que levará ao ápice do clímax e à consciência trágica que se seguirá logo após:

KELLER [pleading]: Chris, a man can't be a Jesus in this world! (p.83) ${ }^{193}$

CHRIS: I know all about the world. I know the whole crap story. Now listen to this, and tell me what a man's got to be! [Reads] "My dear Ann: ...", you listening? He wrote this the day he died. Listen, don't cry.... Listen! "My Dear Ann: it is impossible to put down the things I feel. But l've got to tell you something. Yesterday they flew in a load of papers from the States and I read about Dad and your father being convicted. I can't express myself. I can't tell you how I feel... I can't bear to live any more. Last night I circled the base for twenty minutes before I could bring myself in. How could he have done that?

Every day three or four men never come back and he sits back there doing 'business'... I don't know how to tell you what I feel.... I can't face anybody... I'm going out on a mission in a few minutes. They'll probably report me as missing.

If they do, I want you to know that you mustn't wait for me. I tell you, Ann, if I had him there now I could kill him..." [Keller grabs the letter from Chris's hand and reads it. After a long pause] Now blame the world. Do you understand that letter? $(p .83)^{194}$

\footnotetext{
${ }^{192}$ Bigsby defende as peças posteriores de Miller, a partir de 1962, como sendo de extrema importância para o cânone teatral de modo geral. Fonte: http://www.theguardian.com/culture/2011/aug/19/arthurmiller-america-reputation.

193 [KELLER: (implorando) Chris, um homem não pode ser Jesus nesse mundo.]

${ }^{194}$ [CHRIS: Eu conheço tudo do mundo. Eu sei toda a porcaria da história. Agora escute isto e me diga o que um homem deve fazer! (Lê) "Minha querida Ann:..." Você está escutando? Ele escreveu isto no dia em que morreu. Escute, não chore... Escute! "Minha querida Ann: é impossível deixar de lado as coisas
} 
KELLER: (speaking almost inaudibly) I think I do. Get the car. I'll put on my jacket. (he turns and starts slowly for the house. Mother rushes to intercept him)

$(p .83)^{195}$

Este momento parece ser a última peça do quebra-cabeça a se encaixar, e Joe é forçado a enxergar o presente que agora se apresenta a ele. Chris Keller, ao dizer ironicamente "blame the world", faz um chamado à consciência individual e critica jogar a culpa na sociedade ${ }^{196}$. Keller busca criticar a sociedade que o levou a fazer isso (os esforços de guerra "exigiam" que não houvesse falhas), mas, Miller se mostra cauteloso explicitando, na fala de Chris, que culpar o mundo não resolverá o impasse. Todas as tentativas de evasão, de culpar seu ex-funcionário, de atribuir a culpa aos esforços de guerra caem agora por terra, e a única coisa que ele tem em mãos é um documento que declara o contrário. Joe, que acreditava em sua inocência por conta de um documento que carregava no bolso, agora acreditava em sua culpa por conta da carta de seu filho. Kate tenta impedi-lo, mas, a conscientização de Keller finalmente aparece em uma de suas frases mais emblemáticas na peça:

KELLER: [looking at letter in his hand] Then what is this if it isn't telling me? Sure, he was my son. But I think to him they were all my sons. And I guess they were, I guess they were. I'll be right down (exits into house). (p. 83) ${ }^{197}$

\footnotetext{
que eu sinto. Mas, preciso te dizer uma coisa. Ontem eles trouxeram uma carga de jornais dos Estados Unidos e eu li sobre o meu pai e seu pai sendo condenados, Eu não consigo me expressar. Eu não consigo te dizer como me sinto... eu não suporto mais viver. Ontem à noite fiquei rondando em volta da base vinte minutos até conseguir entrar. Como ele pode ter feito aquilo? Todos os dias três ou quatro homens nunca voltam e ele senta aí fazendo negócios... eu não sei como te dizer o que sinto. Eu não consigo encarar ninguém. Vou sair em uma missão dentro de poucos minutos. Provavelmente vão me dar por desaparecido. Caso isso aconteça, eu quero que você saiba que não quero que você espere por mim. Estou dizendo a você, Ann, se ele estivesse na minha frente agora, eu seria capaz de matá-lo"... (Keller agarra a carta da mão de Chris e a lê. Depois de uma longa pausa) Agora culpe o mundo. Você entende essa carta? ]

195 [KELLER: (fala quase inaudivelmente) Eu acho que sim. Pegue o carro. Eu vou colocar o meu casaco. (ele vira e vai devagar para a casa. Mãe corre para tentar interceptá-lo)]

${ }^{196}$ Esta fala de Chris preconiza, ao nosso ver, o ideário filosófico-existencialista mais explícito que virá em peças escritas adiante, tais como: After the Fall, Incident at Vichy, The Price, dentre outras, em que não se pode alegar o cumprimento de ordens e no qual a escolha e consciência individuais têm papel determinante.

${ }^{197}$ [KELLER: (olhando para a carta em suas mãos) Então, o que é isto aqui, senão ele me dizendo? É claro que ele era meu filho. Mas eu acho que para ele todos eram meus filhos. E acho que eram mesmo, eu acho que eram. Eu já venho (entra na casa).]
} 
Quando Joe Keller diz que todos eram seus filhos, vemos algo interessante: o título "All My Sons" une o coletivo (All) ao privado (My). O pronome possessivo "meus" aponta, certamente, para uma dimensão individual. "Sons" recebe o sentido literal (Larry está morto) e o sentido metafórico de outros filhos, com um sentido bíblico de filhos por extensão. Ao assumir isso, Keller parece ter consciência de que a esfera pública e a privada estão justapostas e que sua queda o levou ao conhecimento do que fizera a si e aos outros. Kate tenta, pela última vez, convencer Chris a não levá-lo preso e argumenta que a guerra já acabou, tentando colocar o passado como um tempo isolado que não repercute no presente. Chris a repreende e elucida o que está por trás do raciocínio de Larry:

CHRIS: You can be better! Once and for all you can know there's a universe of people outside and you're responsible to it, and unless you know that you threw away your son because that's why he died. $(p .84)^{198}$

Neste momento ouve-se o barulho do tiro e o enredo assume 0 denouement, seu desfecho. A consciência trágica, traz a queda de Keller, que comete suicídio. Segundo comenta Weales:

Joe Keller é um self-made man, uma imagem do sucesso americano, que é destruído quando é forçado a ver esta imagem em outro contexto - através dos olhos de seu filho idealista. ${ }^{199}$

O suicídio de Keller é motivo de discussão e se aproxima muito ao de Willy Loman (outro self-made man). Há quem diga que Keller se mata por reconhecer a culpa de ter matado todos os "seus" filhos e há quem diga que

\footnotetext{
${ }^{198}$ [CHRIS: Você pode ser melhor! De uma vez por todas vocês podem perceber que há um universo cheio de gente lá fora e que vocês são responsáveis por ele, e enquanto não entenderem isso, estarão jogando fora seu filho, pois foi por isso que ele morreu.]

${ }^{199}$ WEALES, Gerald. Arthur Miller. In: Downer, A. S (ed). The American Theater. Washington: Voice of America, 1967, p.97.
} 
seu suicídio obrigaria Chris a assumir seus negócios e fazer seu sonho e esforços durante o período de guerra terem valido a pena.

Os últimos instantes do desfecho são memoráveis, na fala final de Kate:

MOTHER: Don't, dear. Don't take it on yourself. Forget now. Live. [Chris stirs as if to answer.] Shhh... [She puts his arms down gently and moves towards porch.] Shhh... [as she reaches porch steps she begins sobbing] (p.84) 200

Aqui fica evidente que Kate repete o padrão de sempre: "forget now" e "live" indicam que ela quer que o filho "coloque uma pedra em cima do que aconteceu" e não sinta culpa por ter condenado o pai à morte. Ao mandar o rapaz ficar em silêncio, Kate se aproxima do portão e é obrigada a encarar a dor do passado, convertida num triste choro pela perda não só de seu filho Larry e dos pilotos que lutaram na guerra, mas, agora de Joe Keller. A relação de causação está estabelecida e materializada na forma de tragédia analítica adotada por Miller nesta obra-prima.

\footnotetext{
${ }^{200}$ [MÃE: Não, querido. A culpa não é sua. Esqueça agora. Viva. (Chris mexe-se como que para responder) Shhh... (Ela se desprende dos braços dele delicadamente e vai em direção à varanda) Shhhh... (ao chegar nos degraus, ela começa a chorar.)]
} 


\subsection{RUBRICAS}

All My Sons é uma peça cuja forma traz não somente inovação, mas escancara de maneira soberba o potencial artístico de Arthur Miller. Assim como Ibsen, Miller constrói a peça de maneira tão precisa e elaborada que confere a ela um alcance político, social e dramatúrgico de proporções gigantescas. Nela, todas as partes se ligam de maneira artesanal e orgânica. A análise do enredo, feita no segmento anterior, buscou demonstrar a forma como as partes se encontram perfeitamente concatenadas em seu encadeamento, o que garantiu coerência e claridade ao que se passou no passado e ao que se passa no presente. Rubricas que revelam personagens, personagens que executam ações que formam o enredo e um enredo que tem como ação a análise das próprias personagens, explicitando desta maneira a técnica analítica de Ibsen. A peça incorpora também outros elementos (comentados no item enredo) que fortificam a dramaturgia milleriana e de certa forma trazem um Ibsen reformulado aos Estados Unidos. Analisaremos neste item as rubricas e de que maneira elas colaboram com a construção da dialética entre forma e conteúdo. Segundo Pita:

"(...) as rubricas possuem um caráter objetivo e isso deve ser levado em conta (...) e limitam-se a breves descrições sobre os elementos cênicos, o que nos leva a afirmar que a característica predominante nas rubricas é o descritivismo, embora não raro, encontrem-se exemplos que narrem o andamento de uma ação ${ }^{201} . "$

As rubricas da peça narram, sem verbalizar, o passado. Elas apontam como 0 passado está no presente sem precisar ser dramatizado. Apontaremos algumas que nos chamaram a atenção e que nos trouxeram a perspectiva de um elemento gestáltico que permite uma compreensão mais global. A rubrica é uma das peças do quebra-cabeça que auxilia a compreensão do que está na peça e fora dela, e este elemento fundamental possui a função primária de dar

\footnotetext{
${ }^{201}$ PITA, Fernando. A reversibilidade do texto teatral rodrigueano. In: Palimpsesto 3. Rio de Janeiro, Caetés, 2003, p.96-109.
} 
marcações às cenas, indicar o tom e emoção a serem usados pelo ator etc. Dentre essas funções, no caso de Miller, as rubricas em All My Sons têm uma natureza descritiva (ao contrário de Tennessee Williams, por exemplo, que as utiliza de maneira poética). Tais descrições são essenciais para outras partes constituintes da peça que em muitos casos reforçam a natureza das personagens (ajudando a compreendê-las de maneira mais ampla) e se encaixam (como peças de um quebra-cabeça) para que o enredo também seja melhor construído.

Antes que o Primeiro Ato comece temos imediatamente na rubrica a descrição do espaço em que a peça se desenvolve, assim como a explicação sobre as personagens envolvidas. The back yard of the Keller home in the outskirts of an American town. August of our era é a informação inicial que temos sobre a peça. O cenário é propício para o desenvolvimento de um 'drama familiar' que acontece em Agosto, tempo de verão nos Estados Unidos, e que indica ao leitor que à frente, como nos lembra Bigsby, está o outono ${ }^{202}$. O ambiente ganha uma atmosfera isolada, pois Miller coloca árvores plantadas uma ao lado da outra em ambos os lados ao redor da casa que se encontra no centro do palco. A casa de dois andares e sete quartos é descrita na rubrica como "it would have cost perhaps fifteen thousand in the early twenties when it was built” (p.5). Temos aqui uma informação importante com relação ao custo da casa que já indica que a família que vive nela pertence potencialmente a uma classe com um pouco mais de dinheiro. No canto esquerdo, e isto é extremamente fundamental para a composição da peça, há um toco de macieira de aproximadamente $1,20 \mathrm{~m}$ cujos galhos e parte de cima estão derrubados ao lado. Esta construção do espaço espelha os elementos do passado presentificados na cena.

A peça se inicia quando Joe Keller, o chefe da família que conheceremos mais adiante, lê seu jornal no Domingo de manhã. Miller indica que Joe Keller is sitting in the sun reading the want ads of the Sunday paper, the other sections of which lie neatly on the ground beside him (p.5). Já temos aqui algumas pistas sobre o estilo de Joe Keller. Ao escolher a parte de classificados para

\footnotetext{
${ }^{202}$ Neste momento o leitor pode inferir o duplo sentido da palavra 'fall'em inglês que, além de 'outono' também pode ser traduzido como o substantivo 'queda' ou como o verbo 'cair'.
} 
ler, Keller parece mais interessado em saber sobre os desejos e aspirações das pessoas do que em ler a seção de notícias, por exemplo. Keller, que se aproxima dos sessenta anos, é descrito como um homem de negócios que traz consigo a marca de um trabalhador e de chefe. Miller nos informa algo importante sobre Keller:

When he reads, when he speaks, when he listens, it is with the terrible concentration of the uneducated man for whom there is still wonder in many commonly known things, a man whose judgements must be dredged out of experience and a peasant-like common sense. A man among man. ${ }^{203}$

Esta descrição que Miller faz de Keller já explicita que Keller é um "homem comum", cujos conhecimentos sobre as coisas parecem estar limitados a um cosmos restrito no qual os 'iletrados' (uneducated) normalmente encontram conhecimento. A entrada da personagem Kate, que é descrita por Miller como Mãe, traz a seguinte informação:

A woman of uncontrolled inspirations, and an overwhelming capacity for love. ${ }^{204}$

Um fato curioso para se atentar é que as rubricas com função de caracterização de personagens, na peça, parecem concentrar-se nos aspectos da caracterização psicológica, não tocando em aspectos de caracterização física que O'Neill, por exemplo, geralmente inclui. Tais caracterizações auxiliam a compreensão do quebra-cabeça que será formado na peça com o auxílio da técnica analítica.

\footnotetext{
${ }^{203}$ p.5-6 [Quando ele lê, quando fala, quando escuta é com a terrível concentração do homem iletrado para o qual ainda há assombro em muitas das coisas comumente conhecidas, um homem cujos julgamentos têm de ser recolhidos na experiência e num senso comum camponês.]

${ }^{204}$ p.18 [Uma mulher de inspirações descontroladas, e uma capacidade imensa de amar.]
} 
Kate Keller entra conversando com o marido sobre batatas e outras coisas aparentemente triviais, quando em um momento desce ao jardim e evoca, através da memória, o passado dizendo:

MOTHER [picks a few petals off ground, stands there smelling them in her hand, then sprinkles them over plants]: No more roses. It's so funny... everything decides to happen at the same time. This month is his birthday; his tree blows down, Annie comes. Everything that happened seems to be coming back (...) (p.19) $)^{205}$.

O fato de ela apanhar flores e ficar parada a faz pensar em algo. Os momentos de silêncio normalmente expressam mais do que a verborragia sem sentido. As peças de Tchekhov, por exemplo, são exemplo claro de que o não-verbal de fato "fala", ou seja, transmite elementos importantes para a esfera da caracterização. É nesse momento paradoxal de divagação e lucidez que Kate atesta que o presente está impregnado de memórias e coisas do passado, e que elas são inescapáveis. Kate menciona o sonho que tivera com Larry e as rubricas indicam algo precioso:

MOTHER: I was fast asleep, and... [raising her arm over the audience]. Remember the way he used to fly low past the house when he was in training?

When we used to see his face in the cockpit going by? That's the way I saw him. Only high up. Way, way up, where the clouds are. He was so real I could reach out and touch him. And suddenly he started to fall. And crying, crying to me... Mom, Mom! I could hear him like he was in the room. Mom! ...it was his voice! If I could touch him I knew I could stop him, if I could only... [breaks off, allowing her outstretched hand to fall] I woke up and it was so funny... The wind... it was like the roaring of his engine. I came out here...I must've still been half asleep. I could hear that roaring like he was going by. The tree snapped right in front of me....and I like...came awake. [She is looking at the tree. She suddenly realizes something, turns with a reprimanding finger shaking slightly at

\footnotetext{
205 p.19 [MÃE: (apanha algumas pétalas do chão, fica parada sentindo o cheiro delas, e então as joga por cima das plantas) Não há mais rosas. É engraçado... tudo decide acontecer ao mesmo tempo. Este mês é o aniversário dele; a árvore dele é derrubada, Annie chega. Tudo que aconteceu parece estar voltando.]
} 
Keller]. See? We should never have planted that tree. I said so in the first place; it was too soon to plant a tree for him. ${ }^{206}$

As rubricas dão indicações de comportamentos não-verbais que expressam o passado sem utilizar palavras. Ao levantar os braços, ao deixar as mãos caírem ou ao olhar para a árvore e apontar o dedo em atitude de repreensão ao marido, é o passado que está incorporado no presente, mas, ainda emudecido, sofre resistências pelas evasões verbais que sempre o cortam. Uma vez mais, a situação não é diferente: Kate joga seu sentimento de culpa na superstição, dizendo que a árvore não deveria ter sido plantada ainda, pois era muito cedo e a referência e discussão do passado são cortados quando Kate pede a Chris uma aspirina ao que ele responde que sim, e Chris planeja que os quatro (Joe, Kate, Chris e Ann) saiam para dançar e jantar na praia. Este momento que poderia ser o início de uma grande revelação, é interrompido novamente pela chegada de Bert, o garoto que brinca de polícia e bandido com Keller. Kate se irrita e uma vez mais revela, pelas indicações na rubrica, como o passado a afeta inclusive de maneira física:

MOTHER: Go home, Bert. [Bert turns around and goes up driveway. She is shaken. Her speech is bitten off, extremely urgent.] I want you to stop that, Joe! That whole jail business! $(p .23)^{207}$

KELLER [alarmed, therefore angered]: Look at you, look at you shaking. $(\text { p. } 23)^{208}$

MOTHER [trying to control herself, moving about clasping her hands]: I can't help it.(p.23) 209

\footnotetext{
${ }^{206}$ [Eu dormi rapidamente e... (levantando seu braço sobre a plateia) Lembra como ele passava voando em cima de casa quando estava treinando? E a gente via o rosto dele na cabine quando passava? Foi assim que eu vi. Só que lá em cima. Muito, muito alto, na altura das nuvens. Foi tão real que eu podia esticar a mão e tocar nele. E, de repente, ele começou a cair. E gritando, gritando por mim... Mãe, mãe! Eu ouvia como se ele estivesse aqui mesmo. Mãe!... era a voz dele! Se eu conseguisse tocá-lo, eu sabia que eu poderia impedi-lo, se ao menos... (silencia, deixa cair o braço estendido) Acordei e foi tão engraçado... o vento... era como o ronco do motor dele. Eu vim aqui para fora... eu devia estar meio adormecida. Dava para ouvir aquele ronco como se ele estivesse passando. A árvore quebrou bem na minha frente... e aí foi como se eu acordasse. (ela está olhando para a árvore. De repente ela percebe algo, vira-se com um dedo trêmulo de repressão a Keller) Está vendo?A gente nunca deveria ter plantado essa árvore. Eu sempre disse isso. Era cedo demais para plantar uma árvore para ele.]

${ }^{207}$ [MÃE: Vá para casa, Bert. (Bert se vira e vai em direção à rua. Ela está abalada. Seu discurso está acanhado, extremamente urgente.) Eu quero que você pare com isso, Joe! Todo esse negócio de cadeia!] ${ }^{208}$ [KELLER: (alarmado, portanto irritado) Olhe só para você, olha só você tremendo.]

209 [MÃE: (tentando se contrar, movendo-se e apertando as mãos) Eu não consigo evitar.]
} 
Estes gestos (ou Gestus brechtiano ${ }^{210}$ ?) de Kate são um sintoma de que quando o passado se infiltra no presente de maneira mais direta, Kate evidencia isso inclusive fisicamente ${ }^{211}$ (ela está abalada e seu discurso está curto). Joe também apresenta o sintoma do passado (ele está alarmado e bravo). O não-verbal chega a ser tão forte, que em outro momento Ann, por ocasião da descoberta de que o quarto de Larry continuava arrumado e seus sapatos estavam lustrados, a encara em silêncio, como quem está comunicando algo sem dizer palavras:

ANN [slowly rising, a little embarrassed]: Well, it never occured to me that you'd... I mean the shoes are all shined. (p.26) $)^{212}$

MOTHER: Yes, dear. [Slight pause. Ann can't stop staring at her. Mother breaks it by speaking with the relish of gossip, putting her arm around Ann and walking with her.] For so long l've been aching for a nice conversation with you, Annie. Tell me something. (p.26) $)^{213}$

Quando a rubrica sinaliza que Ann não consegue parar de encará-la e que Kate quebra isso, essa observação ilustra, justamente, a revelação de que o silêncio transmititu muito mais do que todo o conjunto de diálogos até então

\footnotetext{
${ }^{210}$ Gestus é um termo elaborado por Bertolt Brecht que não é apenas a simples gestualidade, mas a possibilidade de criar atitudes genéricas que os gestos podem demonstrar (Thompson, 1994, p.72). Pela perspectiva brechtiana torna-se um conceito relacionado ao termo "gesto social" que expressa mais do que o físico, em sua singularidade, mostra. A função do "gestus" brechtiano, entretanto, não se desliga de um processo de distanciamento que aqui, em All My Sons, não ocorre. O "gestus" brechtiano acrescenta elementos que se ligam a uma perspectiva exterior à da esfera psicológica da personagem. Trata-se da esfera social, histórica e política. Neste caso temos o contrário: a gestualidade acrescenta, ao que parece, elementos a essa esfera psicológica.

${ }^{211}$ As personagens de All My Sons apresentam frequentemente sintomas de natureza psicossomática. Os tremores, as dores de cabeça e o nervosismo parecem não ser somente de origem física. Em dado ponto Kate Keller, por exemplo, chega a sair de cena para buscar uma aspirina.

${ }^{212}$ [ANN: (lentamente se levantando, um pouco envergonhada) Bem, é que nunca me ocorreu que você ... eu quero dizer, os sapatos estão todos engraxados.]

${ }^{213}$ [MÃE: Sim, querida. (Pequena pausa. Ann não consegue parar de encará-la. Mãe quebra o silêncio ao falar em tom de fofoca, colocando seu braço por cima de Ann e andando com ela.) Por muito tempo eu tenho desejado uma conversa com você, Annie. Me conte alguma coisa.]
} 
desenvolvidos. As intrigas familiares e o abraço forçoso levam as duas para longe dali, verbal e fisicamente falando.

A rubrica que abre o Segundo Ato começa com a descrição "as twilight falls, that evening" que evidencia o padrão de dramaturgia da Tragédia ${ }^{214}$. A cena se inicia com a mãe descendo ao encontro de Chris e trazendo um suco de uva, o favorito de George. Kate procura agradá-lo ao máximo, recorrendo às imagens e gostos agradáveis do passado, desviando, assim, a atenção de assuntos que ele pretenderá trazer ao presente.

KELLER [commanding outburst in his nervousness]: A father is a father! [as though the outburst had revealed him, he looks about, wanting to retract it. His hand goes to his cheek]. I better... I better shave. (p.49-50) ${ }^{215}$

Neste ímpeto de defender que a figura paterna está acima de tudo e deve ser respeitada independente do que aconteça, Keller se auto denuncia. Os signos não-verbais, novamente, revelam o passado, mas os verbais tentam reprimi-lo logo em seguida (I better shave). A força do passado é tamanha, que se torna evidente que ele está circundando e inundando o presente cada vez mais. Em um momento em que George, recém chegado à casa dos Keller, mostra seu tom acusador e tenso, Kate busca "afogar" essa situação com palavras que se opõem ferozmente à realidade, e na rubrica temos novamente coisas interessantes:

MOTHER [at last confessing her tension]: Why should he argue? [she goes to him, and with desperation and compassion, stroking his hair] Georgie and us have no argument. How could we have an argument, Georgie? We all got hit by the same lightning, how can you...? Did you see what happen to Larry's tree,

\footnotetext{
${ }^{214}$ É sabido que a tragédia clássica segue um esquema que comumente se estende a um período de vinte e quatro horas, como já apontado previamente, na unidade de tempo aristotélica.

${ }^{215}$ [KELLER: (Explosão elevada em seu nervosismo) Um pai é um pai! (como se sua explosão o tivesse revelado, ele olha em volta, querendo retrair-se. Sua mão vai à sua bochecha) É melhor... é melhor eu fazer a barba.]
} 
Georgie? [she has taken his arm, and unwillingly he moves across stage with her]. $(\text { p.59) })^{216}$

Esta fala extremamente sintomática e ambígua demonstra o medo que Kate tem de entrar em discussão mais profunda sobre o assunto. A rubrica, em primeiro lugar, indica a tensão de Kate. Logo em seguida, com desespero e compaixão, ela vai mexer no cabelo dele, revelando seu medo em ser descoberta como co-autora do crime e com compaixão por saber que George tem o pai preso injustamente. Kate forçosamente desvia o foco da possível discussão para seu drama pessoal (o de ter o filho desaparecido) e segue contando o sonho que tivera com Larry na noite anterior. É interessante notarmos que Kate não chega a completar a frase, "Nós fomos todos atingidos pelo mesmo raio, como você pode...?" e em seguida faz uma outra pergunta completamente diferente. As reticências em sua fala indicam a repressão de uma coisa importante do passado, e ela termina exatamente como fizera com Ann anteriormente: pegando em seu braço e forçando-o a sair de maneira física (andando com ele pelo palco) da situação verbal que se impõe. Joe Keller prossegue acusando o pai de George em ter problemas para assumir a culpa, citando pequenos incidentes do trabalho, e a tensão e o peso do passado estão novamente descritos na rubrica:

KELLER: (...) There are certain men in the world who rather see everybody hung before they'll take the blame. You understand me, George? [They stand facing each other, George trying to judge him]. (p.64) $)^{217}$

\footnotetext{
${ }^{216}$ [MÃE (finalmente confessando sua tensão): Por que nós brigaríamos? (ela vai até ele com desespero e compaixão, acariciando os cabelos dele) Georgie e nós não temos discussões. Como nós poderíamos discutir, Georgie? Nós todos fomos atingidos pelo mesmo raio, como você pode...? Você viu o que aconteceu com a árvore do Larry, Georgie? (ela o pega pelo braço e com relutância ele anda pelo palco com ela.)]

${ }^{217}$ [KELLER: (...) Há certos homens no mundo que preferem ver alguém enforcado ao invés de assumir a culpa. Você me entende, George? (Eles ficam se olhando cara a cara, George tentando julgá-lo).]
} 
Mesmo com as falácias proferidas por Joe Keller, George, em seu silêncio, não deixa que o passado seja atropelado pelas palavras usadas contra seu pai. Seu olhar expressa justamente o contrário do que acabara de ser afirmado por Joe Keller ${ }^{218}$. Apesar de tudo Kate, certa de que George estava convencido de que seu pai é um homem que não aceita culpa facilmente, convida-o para jantar. Keller entusiasticamente reforça o convite, e Kate cogita a possibilidade de convidar uma garota para George. No clima "descontraído" que agora se estabelecera, George faz alguns elogios à família Keller e neste momento a grande revelação é feita:

GEORGE [he stops, looks around at them and the place]: I never felt at home anywhere but here. I feel so... [he nearly laughs and turns away from them]. Kate you look so young, you know? You didn't change at all. It... rings an old bell. [turns to Keller] You too, Joe, you're amazingly the same. The whole atmosphere is. $(p .65)^{219}$

Este momento preciso mostra que George rende-se às memórias e ao passado, e é este mesmo passado que logo adiante sufocará e implodirá tudo. $\mathrm{Na}$ medida em que este ilude e invade a memória de George, que contempla com saudosismo e afeição o lugar, ele traz a realidade à boca de Kate.

KELLER: Say, I ain't got time to get sick. $(p .65)^{220}$

MOTHER: He hasn't been laid up in fifteen years. $(p .65)^{221}$

\footnotetext{
${ }^{218}$ Este gesto de George para com Keller se assemelha ao gesto de Ann para com Kate mencionado há pouco.

${ }^{219}$ [GEORGE: (ele para, olha ao redor e para eles) Eu nunca me senti tão em casa como aqui. Eu me sinto tão... (ele quase ri e se afasta deles). Kate, você parece tão jovem, sabe? Você não mudou nada. Isso... me lembra muita coisa. (vira-se para Keller) Você também, Joe, você está incrivelmente igual. Toda a atmosfera igual.]

${ }^{220}$ [KELLER: Sabe, eu não tenho tempo para ficar doente]

${ }^{221}$ [MÃE: Ele não fica de cama há quinze anos.]
} 
Em uma tentativa de exaltar a grandeza de Joe Keller, Kate comete um ato falho e acaba incriminando o próprio marido. A tentativa que Kate faz de corrigir o que havia sido dito é em vão.

O Terceiro Ato se inicia às duas horas da manhã, o que completa o ciclo de vinte e quatro horas, típico da tragédia grega. $\mathrm{O}$ ambiente ganha um clima mais sombrio ainda com a descrição na rubrica:

(...) A light shows from upstairs bedroom, lower floor windows being dark. The moon is strong and casts its bluish light. (p.73) $)^{222}$

A iluminação funciona como um recurso que estabelece o estado de espírito entristecido que está refletido em Kate, sentada em uma cadeira de balanço, aguardando que Chris retorne. A luz, um elemento cênico, traduz a própria "iluminação" que o enredo trouxe, mas, sua cor espelha o conteúdo triste e pesado da revelação de que Keller era o responsável pelo crime. Keller não se convence de que sua culpa por extensão é culpa da mesma maneira. Sua mentalidade não the permite enxergar conexões ou responsabilidade sobre algo que diretamente não fora feito por ele: fornecer as peças defeituosas é assumido, matar os pilotos não. As rubricas da fala a seguir ilustram sua posição e seu desejo desesperado de ser compreendido:

KELLER: What should I do? [Chris is silent] Jail? You want me to go to jail? If you want me to go, say so! Is that where I belong? Then tell me so! [Slight pause] What's the matter, why can't you tell me? [Furiously] You say everything else to me, say that! [Slight pause] I'll tell you why you can't say it. Because you know I don't belong there. Because you know! [with growing emphasis and

${ }^{222}$ [Uma luz aparecendo do quarto de cima, janelas do piso inferior escuras. A lua está forte e lança sua luz azulada]. O termo 'bluish' pode ser também entendido como triste, visto que em expressões idiomáticas de língua inglesa esta cor está associada à tristeza, à depressão e ao pesar. Os romanos na república vestiam azul escuro para o luto, assim como em Bucara (Uzbequistão), Coreia, China e diversas tribos africanas. 
passion, and a persistent tone of desperation] Who worked for nothin' in that war? When they work for nothin', I'll work for nothin'. When they ship a gun or a truck outa Detroit before they got their price? Is that clean? It's dollars and cents, nickels and dimes; war and peace, it's nickels and dimes, what's clean? Half the Goddam country is gotta go if I go! That's why you can't tell me. $(p .82)^{223}$

Aqui temos a denúncia aberta do lucro que se fez na guerra às custas de vidas. Mesmo assim, Keller se coloca não como autor de um crime pessoal que se refletiu na esfera social (coletiva), mas, como um membro incorporado que fez o que devia ser feito. Ele não se vê como responsável, já que metade do país estava envolvido nisto. Fez o que fez porque assim a lógica do sistema exigia dele. Seu tom enfático de paixão e desespero descrito na rubrica parece um grito de socorro para que o que fizera no passado seja entendido e compreendido. Após as tentativas frustradas de justificar o que se passara, Joe Keller, admitindo que todos eram seus filhos, comete suicídio. As últimas rubricas da peça estão entre as mais importantes e interessantes de todo o texto:

MOTHER: Don't, dear. Don't take it on yourself. Forget now. Live. [Chris stirs as if to answer.] Shhh... [She puts his arms down gently and moves towards porch.] Shhh... [as she reaches porch steps she begins sobbing] (p.84) ${ }^{224}$

Chris se vira para responder à mãe, mas, esta o silencia com um gesto físico. Em mais um momento no qual algo importante pudesse surgir em cena,

\footnotetext{
${ }^{223}$ [KELLER: O que eu devo fazer? (Chris está em silêncio) Cadeia? Você quer que eu vá para a cadeia? Você quiser, diga! É a aquele lugar que eu pertenço? Então me diga! (pequena pausa) Qual é o problema, por que você não fala? (furiosamente) Você me disse tantas outras coisas, diga isso! (pequena pausa) Eu vou te dizer porque você não consegue dizer. Porque você sabe que eu não pertenço a aquele lugar. Porque você sabe! (com ênfase crescente e paixão, e um tom persistente de desespero) Quem trabalhou em troca de nada naquela guerra? Quando eles trabalharem em troca de nada, eu trabalho em troca de nada. Quando eles despacham uma arma ou um caminhão de Detroit antes de receber o pagamento? Isso é jogo limpo? São dólares e centavos, tostões e vinténs, guerra e paz, são tostões e vinténs, o que é limpo? Metade desse maldito país precisa ir preso se eu for. É por isso que você não consegue me falar.] ${ }^{224}$ [MÃE: Não, querido. A culpa não é sua. Esqueça agora. Viva. (Chris mexe-se como que para responder) Shhh... (Ela se desprende dos braços dele delicadamente e vai em direção da varanda) Shhhh... (ao chegar nos degraus, ela começa a chorar.)]
} 
Kate desvia a atenção. Ela vai até a varanda, tentando novamente escapar verbal e fisicamente da situação, mas, seus soluços começam. A peça termina com o presente inundado pelo passado e seus soluços já não mais servem como evasão ou fuga, eles são o elemento que confirma a "chegada" do passado.

\subsection{PERSONAGENS}

As personagens ${ }^{225}$ da peça e suas características identificáveis no presente nos dão pistas do passado (período no qual as ações principais tiveram lugar). As personagens são o que são no presente por conta do que ocorrera anteriormente e são também prova de que a esfera privada e individual não está separada da coletiva e social. É na interação/embate entre as personagens que estas mesmas revelam suas naturezas e no que elas estão apoiadas. As personagens, em outras palavras, entram em cena para discutir um passado que ainda está vivo e incômodo no presente, como nos lembra Silva (2007:408, Vol II).

Frank, que incorpora o espírito da "boa vizinhança", tem uma conversa bastante trivial com Joe Keller e, ao mesmo tempo, indispensável para que se compreenda a construção de ambos como pesonagens:.

KELLER: Here's another one. Wanted - Old Dictionaries. High prices paid. Now what's a man going to do with an old dictionary? (p.7) ${ }^{226}$

\footnotetext{
${ }^{225}$ Um aspecto para o qual devemos dirigir a nossa atenção é que as personagens de Miller normalmente têm em seus nomes alguma representação maior. A escolha, longe de ser aleatória, contribui para o enriquecimento de suas peças permitindo que se enxergue nela um trocadilho ou mesmo uma referência à realidade. A título ilustrativo podemos comentar que em All My Sons, como lembra Christopher Bigsby, há aliteração entre 'Keller'e 'Killer' ou mesmo mesmo pode-se evocar a comparação de 'Chris' com 'Christ'. Death of a Salesman e The Ride down mount Morgan trazem respectivamente 'Willy Loman' e 'Lyman Felt', cujos nomes são forte associação à caracterização das personagens. Em The Crucible, 'John 'Proctor', o protagonista de 'The Crucible', tem seu nome herdado de 'Jimmy Proctor', um publicitário de teatro amigo de Miller e de Kazan, que fora apontado à HUAC por este último.

${ }^{226}$ [KELLER: Aqui está outro. Procura-se - dicionários antigos. Paga-se bem. Ora, o que alguém vai fazer com um dicionário antigo?]
} 
FRANK: Why not? Probably a book collector. $(p .7)^{227}$

KELLER: You mean he'll make a living out of that? $(p .7)^{228}$

FRANK: Sure, there's a lot of them. (p.7) $)^{229}$

KELLER [shakes his head]: All the kind of business goin' on. In my day, either you were a lawyer, or a doctor, or you worked in a shop. Now... (p.7 $)^{230}$

Mais adiante Keller (p.7) diz:

KELLER: (...) you look at a page like this you realize how ignorant you are. $(p .7)^{231}$

Esta fala inicial já explicita a natureza de Joe Keller: um homem comum cujo padrão de avaliação das coisas é considerado, por ele mesmo, como "ignorante". Sua concepção de negócios segue uma tendência tradicional em que apenas doutores, advogados e trabalhadores de loja são os que têm "um emprego de verdade". Keller apresenta uma praticidade tamanha que o mundo letrado não faz parte de seu interesse e de seu entendimento. Um pouco adiante um outro traço fundamental de Keller é explicitado:

\footnotetext{
${ }^{227}$ [FRANK: Por que não? Provavelmente um colecionador de livros.]

${ }^{228}$ [KELLER: Você está me dizendo que alguém ganha a vida com isso?]

229 [FRANK: Claro, há muitas pessoas que fazem isso.]

230 [KELLER: (balançando a cabeça) Todo tipo de negócios acontecendo. No meu tempo, ou você era um advogado, ou médico, ou você trabalhava em uma loja. Agora...]

${ }^{231}$ [KELLER: Você olha para uma página dessas e você se dá conta do quão ignorante você é.]
} 
KELLER: How can you make him a horoscope? That's for the future, ain't it? $(p .7)^{232}$

Tal pergunta, que parece ser inocente, já esconde uma implicação essencialmente importante para o que será revelado adiante no decorrer da peça: se a previsão é para o futuro de Larry, de que serve? Keller parece ter admitido (in)conscientemente que para Larry não há futuro.

Frank, que crê nos astros, se recusa a acreditar no suposto fato e imediatamente diz que é praticamente impossível o filho de Keller estar morto, pois o dia de morte estimado para Larry coincidia com o "Dia Favorável" dele. Jimmy, o outro vizinho casado com Sue, se caracteriza por ser o oposto de Frank. Jimmy é médico e condena qualquer tipo de ilusão ou subjetividade. Em dado momento da peça seu embate com Frank é direto:

FRANK [peeved]: The trouble with you is, you don't believe in anything. $(p .8)^{233}$

JIM: And your trouble is that you believe in anything. $(p .8)^{234}$

Esta passagem é riquíssima de significado, sendo que Frank espelha exatamente o entusiasmo da sociedade americana nos tempos de guerra ${ }^{235}$. "Acreditar" é a base de tudo, daí sua crítica a Jim. Jim critica Frank por acreditar em qualquer coisa, o que indica um senso um pouco mais crítico das

\footnotetext{
${ }^{232}$ [KELLER: Como você pode fazer um horóscopo para ele? Isso é para o futuro, não é?]

233 [FRANK: (irritado) O seu problema é que você não acredita em nada.]

234 [JIM: E o seu problema é que você acredita em qualquer coisa.]

${ }^{235} \mathrm{O}$ empenho dos americanos foi tamanho durante o período de guerra, que as mulheres, cuja imagem estava associada à de 'donas no lar', começaram a ir para as fábricas, assim como os negros (até então segregados racialmente) também participaram para os esforços de guerra com cerca de um milhão de combatentes. Tal contingente, certamente, teve forte motivação econômica.
} 
coisas. Em outro momento, Frank critica Jim dizendo que ele deveria fazer um trabalho que ajudasse a humanidade, no que Jim imediatamente responde:

JIM: I would love to help humanity on a Warner Brothers salary. $(p .9)^{236}$

Aqui transparece a associação que $\operatorname{Jim}$ faz de uma atividade que não envolve dinheiro com algo que devesse ser pago para ser feito, o que pode ser entendido por extensão como o americano normalmente também o faz. Sue, a esposa de Jim, é descrita por Miller como rounding forty, an overweight woman who fears it (p.9). Sue se aproxima muito da cidadã média americana: vem à casa de Joe para falar sobre os pacientes de seu marido Jim, pede um pouco de salsa emprestada e faz o papel de boa vizinha. Mesmo com sua entrada rápida em cena podemos ver evidenciado uma vez mais o quanto o dinheiro é algo que certamente, segundo Sue, leva as pessoas a fazer qualquer coisa:

SUE: It seems to me that for ten dollars you could hold his hand. $(p .10)^{237}$

Tal frase, que parece ser despretensiosa, carrega todo o significado do que está por trás da ideologia do American Dream: atingir o sucesso e a felicidade. O veículo para se atingir tais objetivos é, certamente, o dinheiro. E, por dinheiro, se faz qualquer coisa, inclusive segurar a mão de um de seus pacientes chamado Mr.Hubbard. Lydia, esposa de Frank, é uma garota risonha e robusta de vinte e sete anos que em muitos aspectos se assemelha ao estereótipo da dona de casa, obediente e dependente do marido até para ligar a torradeira. Ela representa o inverso daquilo que as mulheres buscavam ser e se mostrar no período da guerra e sua limitação e infantilidade remetem à alienação tão comum a diversas pessoas que não sabiam ou nem se interessavam em saber o que acontecia.

\footnotetext{
236 [JIM: Eu adoraria ajudar a humanidade com um salário da Warner Brothers.]

237 [SUE: Me parece que por dez dólares você poderia segurar a mão dele.]
} 
Chris Keller mostra, um pouco adiante, que a alienação pode ser uma opção, e diz algo que revela não somente a natureza da personagem, mas, sinaliza coisas do enredo que estão ligadas ao mesmo tempo ao passado e ao presente:

CHRIS: I like to keep abreast of my ignorance. $(p .12)^{238}$

Essa fala é bastante sintomática, pois é justamente o inverso dela que levará a família Keller à descoberta da tragédia à qual estão ligados. Este reconhecimento já prenuncia o fato de que Chris, apesar de sua coerência, se manterá na ignorância quando for preciso, mas, ele mesmo sabe que isso terá um custo. Em conversa com seu pai, Chris diz que ambos estão cometendo um erro em negar a morte de Larry:

CHRIS: Being dishonest with her. That kind of thing always pays off, and now it's paying off. (p.14) 239

Bert, o garoto de oito anos, que entra pulando nas costas de Keller, tem uma relação lúdica e descontraída, bastante comum entre alguns adultos e crianças. A brincadeira que une os dois, contudo, é fortemente uma representação simbólica do contexto real de Joe Keller. Nesta brincadeira entre os dois vemos que Keller se coloca como chefe/delegado "when I first made you a policemen"(p.12) e "I'm liable to make you a detective" e Bert é o policial que obedece: "I made them go away because you were sleeping" (p.12). Bert diz não ver grades da prisão, mas Joe diz que há uma prisão no porão ${ }^{240}, 0$ que sinaliza a situação de Joe Keller em termos simbólicos, na qual a verdade e seu crime estão escondidos atrás dessas mesmas grades. Keller, em sua informalidade brincalhona, pede que o garoto mantenha os olhos abertos, o

\footnotetext{
${ }^{238}$ [CHRIS: Eu gosto de estar a par da minha ignorância.]

${ }^{239}$ [CHRIS: Ser desonesto com ela. Esse tipo de coisa sempre aparece, e agora está aparecendo.]

240 Aqui podemos pensar no porão enquanto um lugar escuro, vazio e sombrio, que é uma imagem coletiva bastante recorrente e dentro do qual se guardam coisas ao invés de jogá-las fora.
} 
que diz respeito à sua própria grande tarefa depois que a guerra acabou. Em primeiro lugar Keller coloca que a vizinhança depende dele, colocando-se no centro das relações humanas como provedor. Logo em seguida, ensina a Bert que um policial não deve fazer perguntas e sim, subordinar-se sem questionamento, já que a ordem vem de uma autoridade.

Em um momento Ann diz querer festejar como nos tempos antes de Larry ter ído à guerra e Kate demonstra sua ilusão (ou mentira):

KATE [emotionally]: You think of him! You see? [triumphantly] She thinks of him! (p.25) ${ }^{241}$

Esta fala revela mais do que um sentimento de mãe na esperança de encontrar o filho. Seu triunfo é justamente não admitir a si mesma que o filho esteja morto e que, consequentemente, fora culpada por conivência. Sua vontade de se manter inocente, como nos lembra Feldman ${ }^{242}$, expressa metaforicamente um desejo de reencontrar o Paraíso perdido. Kate revela parcialmente que há coisas que eles não sabem, revelando sua "inocência" cega:

MOTHER [going to her]: because certain things have to be, and certain things can never be. Like the sun has to rise, it has to be. That's why there's God. Otherwise anything could happen. But there's God, so certain things can never happen. $(p .28)^{243}$

Esta "inocência" não é, assim, tão verdadeira, pois aparentemente ela parece refletir uma fé em Deus (algo tão comum ao povo americano). A crença

\footnotetext{
${ }^{241}$ [MÃE: (emocionalmente) Você pensa nele! Está vendo? (triunfantemente) Ela pensa nele!]

${ }^{242}$ FELDMAN, Alexandre D. O Éden de Arthur Miller. Elementos bíblicos e existencialistas na peca $A$ Criação do Mundo e Outros Negócios: seriedade e crítica em uma obra cômica. (Tese de Doutorado em Língua Hebraica, Literatura e Cultura Judaicas pela FFLCH) - Universidade de São Paulo. Orientador: Nancy Rosenchan, 2006, p.118.

${ }^{243}$ [MÃE: (indo na direção dela) Porque certas coisas têm de ser e certas coisas jamais podem ser. Assim como o sol precisa nascer, ele precisa nascer. Por isso existe Deus. Caso contrário, qualquer coisa pode acontecer. Mas existe Deus, por isso certas coisas jamais podem acontecer.]
} 
inerente à cultura americana de que Deus está ao lado do povo americano é expressa no 'Destino Manifesto' daquele país. Contudo, esta fala avança em outro sentido simultaneamente: ela é uma referência à impossibilidade de Deus permitir que um pai mate o próprio filho (fala que será retomada por Kate mais adiante, mas, desta vez, de maneira explícita e não-metafórica ${ }^{244}$. A mãe procura manter essa imagem de que Joe Keller é inocente de forma tão aguda que se sente verdadeiramente incomodada pelas brincadeiras entre ele e 0 garoto Bert. Enquanto Kate busca isentar a si mesma e ao marido de responsabilidade, Ann e Chris buscam afirmar a responsabilidade do suposto "culpado" pelo crime de ter enviado peças defeituosas durante a guerra. Keller, que diz não acreditar na crucificação de pessoas e ressalta que Steve é, acima de tudo, seu pai, mas, sua tentativa é em vão. É nesta passagem emblemática entre Ann, Chris e 'Mãe' que enxergamos as peças de um quebra-cabeça se encaixando:

ANN: (...) Father or no father, there's only one way to look at him. He knowingly shipped out parts that would crash an airplane. And how do you know Larry wasn't one of them? (p.31) $)^{245}$

MOTHER: I was waiting for that. [going to her] As long as you're here Annie, I want to ask you never to say that again. (p.31 $)^{246}$

CHRIS: It takes a little time to toss that off. Because they weren't just men. For instance, one time it'd been raining several days and this kid came to me, and gave me his last pair of dry socks. Put them in my pocket. That's only a little thing . . . but ... that's the kind of guys I had. They didn't die; they killed themselves for each other. I mean that exactly; a little more selfish and they'd've

been here today. And I got an idea - watching them go down. Everything was being destroyed, see, but it seemed to me that one new thing was made. A kind of ... responsibility. Man for man. You understand me? - To show that, to bring that on to the earth again like some kind of a monument and everyone would feel it standing there, behind him, and it would make a difference to him.... And then I came home and it was incredible. I . . there was no meaning in it

\footnotetext{
${ }^{244}$ Aqui vemos estampada a 'tentação da inocência', da qual Terry Otten fala em seu livro 'The Temptation of Innocence in the Dramas of Arthur Miller'. É ela que condenará as personagens de Miller à queda e, posteriormente, ao autoconhecimento apontando para a descoberta de que não há inocentes. ${ }^{245}$ [ANN: Pai ou não-pai, só há uma maneira de enxergá-lo. Ele conscientemente enviou peças que poderiam derrubar um avião. E como você sabe se Larry não estava em um deles?] ${ }^{246}$ [MÃE: Eu estava esperando por isso. (indo em sua direção) Enquanto você estiver aqui, Annie, eu quero pedir que você não fale mais sobre isso.]
} 
here; the whole thing to them was a kind of a - bus accident. I went to work with Dad, and that rat-race again. I felt ... what you said . . . ashamed somehow. Because nobody was changed at all. It seemed to make suckers out of a lot of guys. I felt wrong to be alive, to open the bank-book, to drive the new car, to see the new refrigerator. I mean you can take those things out of a war, but when you drive that car you've got to know that it came out of the love a man can have for a man, you've got to be a little better because of that. Otherwise what you have is really loot, and there's blood on it. I didn't want to take any of it. And I guess it included you. (p.35-6) $)^{247}$

Esta passagem incorpora, em Chris, a perplexidade de Miller com 0 modo como as pessoas lidaram com as questões que a guerra colocava. A alienação e indiferença com a qual as pessoas se deparavam nos tempos de guerra suscitavam a inconformidade de Chris, que buscava mostrar a conexão entre as esferas privadas de cada um (o carro, a casa) com as esferas coletivas (os esforços coletivos de guerra, a dedicação de uma vida à outra). $\mathrm{O}$ tema da responsabilidade social é escancarado e brilhantemente colocado por Chris nesta passagem. As palavras de Chris Keller parecem ecoar a máxima do filósofo francês Lévinas de que a ética da responsabilidade deve anteceder a da liberdade ${ }^{248}$.

Novamente Kate busca afirmar sua inocência quando fica sabendo que George vem para ressuscitar e fixar o que foi deixado para trás. Assumindo

\footnotetext{
${ }^{247}$ [CHRIS: Leva algum tempo para se livrar disso. Porque eles não eram só homens. Por exemplo, uma vez estava chovendo há muitos dias e um garoto veio e me deu o seu último par de meias seco. Pôs no meu bolso. É pouca coisa... mas... era esse tipo de sujeito que estava comigo. Eles não morreram: eles se mataram uns pelos outros. É exatamente isso que eu quero dizer: um pouquinho mais egoístas e eles estariam aqui hoje. E eu tive uma ideia - olhando eles morrerem. Tudo estava sendo destruído, sabe, mas me pareceu que uma coisa nova surgiu. Uma espécie de... responsabilidade. De homem para homem. Está entendendo? Mostrar aquilo, trazer aquilo de volta para a terra feito algum monumento e todo mundo ia sentir aquilo ali parado, por trás, e isso faria uma diferença para a pessoa. (pausa) E então eu voltei para casa e foi incrível. Eu... não fazia sentido aqui. A coisa toda para eles era como se fosse... um acidente de ônibus. Fui trabalhar com meu pai, e aquela corrida maluca outra vez. Eu senti... como você disse... vergonha de alguma forma. Porque ninguém mudou nada. Aquilo parecia fazer de idiota uma porção de gente. Eu senti que era errado estar vivo, abrir um talão de cheques, dirigir um carro novo, ter geladeira nova. Quer dizer, a guerra pode dar essas coisas para a gente, mas quando você dirige esse carro você tem que saber que ele veio do amor que um homem pode sentir por outro, você tem que ser um pouco melhor por causa disso. Senão o que você tem foi na verdade saqueado e está cheio de sangue. Eu não queria aceitar nada disso. E acho que você fazia parte disso.]

${ }^{248}$ LÉVINAS, Emmanuel. Entre Nós: Ensaios sobre a alteridade. Petrópolis: Vozes, 1997.
} 
sincera ou estrategicamente que ela e o marido são pessoas ignorantes, pessoas que não sabem sobre nada e precisam ser protegidas, Kate diz:

MOTHER: (...) We're dumb, Chris. Dad and I are stupid people. We don't know anything. You've got to protect us. $(p .41)^{249}$

Esta passagem expressa uma das falas mais importantes de Miller em Timebends: "A inocência mata”. Esta máxima alerta para o desejo permanente de retornar a um estado de infância ou ao paraíso perdido, a que Kant chamou de "menoridade". Neste processo o pensamento individual se submete a um poder tutelar alheio que pensa e toma decisões por ele. Contudo, como nos lembra Feldman:

Indivíduos com pensamentos próprios estão sartreanamente condenados à liberdade, e o homem, ao se defrontar com esse aspecto desesperador da escolha, sente-se completamente desamparado $(. . .)^{250}$

Enquanto a tentação da inocência é mostrada por Kate, que insiste em se mostrar como vítima do destino, Sue entra em cena para fincar, sem rodeios, o passado através de um conflito com Ann:

ANN [turns, startled]: Oh! (p.43) 251

SUE: I'm terribly sorry. (p.43) 252

ANN: I'm a little silly about the dark. $(p .43)^{253}$

SUE: It's getting dark. (p.43) 254

\footnotetext{
${ }^{249}$ [MÃE: (...) Nós somos "burros", Chris. Papai e eu somos pessoas idiotas. Nós não sabemos nada. Você tem que nos proteger.]

${ }^{250}$ FELDMAN, Alexandre D. O Éden de Arthur Miller. Elementos bíblicos e existencialistas na peca $A$ Criação do Mundo e Outros Negócios: seriedade e crítica em uma obra cômica. Op.cit., 2006, p.193.

${ }^{251}$ [ANN: (vira-se, assustada): Oh!]

252 [SUE: Eu sinto muitíssimo.]

${ }^{253}$ [ANN: Eu fico meio amedrontada com o escuro.]
} 
O duplo sentido desta última frase de Sue é justamente o que reflete 0 clima do que está por vir. É esse mergulho na escuridão que iminentemente virá, que deixa a todos apreensivos. A conversa que se seguirá entre as duas é de natureza das coisas aparentes e ocultas e merece ser comentada:

SUE: And he's got the money. That's important, you know. (p.44) $)^{255}$

ANN: It wouldn't matter to me. $(p .44)^{256}$

SUE: You'd be surprised. It makes all the difference. I married an interne. On my salary. And that is bad, because as soon as a woman supports a man he owes her something. You can never owe somebody without resenting them. [Ann laughs]. That's true, you know. (p.44) 257

Sue revela que as relações externamente são uma coisa, mas estão profundamente ligadas a outros fatores muitas vezes (in)visíveis. O dinheiro é visto, uma vez mais, como o catalisador que moldará os relacionamentos e, logo em seguida ela explica o ressentimento do qual falava:

SUE: (...) It's bad when a man always sees bars in front of him. Jim thinks he is in jail all the time. $(p .44)^{258}$

SUE [with growing feeling]: Chris makes people want to be better than it's possible to be. He does that to people. (p.44) 259

\footnotetext{
${ }^{254}$ [SUE: Está ficando escuro.]

${ }^{255}$ [SUE: E ele tem dinheiro. Isso é importante, sabe.]

${ }^{256}$ [ANN: Não faria diferença para mim.]

${ }^{257}$ [SUE: Você ficaria surpresa. Faz toda a diferença. Eu me casei com um médico-residente. Que dependia do meu salário. E isso é ruim porque assim que uma mulher começa a sustentar um homem, ele deve algo para ela. Você nunca pode dever algo a alguém sem ressinti-los. (Ann ri). É verdade, sabe.] ${ }^{258}$ [SUE: É ruim quando um homem sempre vê grades à sua frente. Jim achava que está aprisionado o tempo todo.]

${ }^{259}$ [SUE: (com um sentimento crescente) Chris faz com que as pessoas queiram ser melhores do que é possível ser. Ele faz isso com as pessoas.]
} 
SUE: I resent living next door to the Holy Family. It makes me look like a bum, you understand? $(\mathrm{p} .45)^{260}$

SUE: Who is he to ruin a man's life? Everybody knows Joe pulled a fast one to get out of jail. $(p .45)^{261}$

SUE: (...) There is not a person on the block who doesn't know the truth. $(\text { p. } 45)^{262}$

SUE: (...) They give him credit for being smart... (p.45) 263

Miller novamente através do diálogo das personagens e seus embates, joga o passado e a verdade no meio do palco como um raio certeiro. Desta vez, contudo, a verdade é dita em termos explícitos. O aspecto interessante desta revelação é que ela entrelaça a dimensão individual à coletiva, mostrando como uma está contida na outra e como as ações individuais afetam o todo.

George é, na peça, a grande personagem desestruturadora. Sua chegada prenuncia um desastre iminente que buscará ser contornado por Ann, Chris, Keller e Kate em vão. Na medida em que George traz o passado à tona, todos os outros procurarão afogá-lo, mas se esquecem que eles estão neste mesmo passado. A tentativa desastrosa trará a tragédia à família. George afirma ter acreditado no julgamento de seu pai como culpado, até então, porque Chris assim o fizera. É possível enxergar o peso que um discurso competente ${ }^{264}$ tem e de que maneira ele molda certos comportamentos. Chris, exemplo de filho, acreditou no julgamento, portanto George também. Mas, George decide ouvir isso do próprio pai e muda de ideia. Sua chegada à casa dos Keller está cercada de memórias de seu passado materializadas no espaço e nas personagens. Lydia é, para ele, uma das que mais fortemente

\footnotetext{
${ }^{260}$ [SUE: Eu ressinto em morar perto da Família Sagrada. Isso me faz parecer parecer uma vagabunda, entende?]

${ }^{261}$ [SUE: Quem ele acha que é para arruinar a vida de um homem? Todo mundo sabe que o Joe mentiu para sair da cadeia.]

${ }^{262}$ [SUE: (...) Não há uma pessoa na vizinhança que não saiba da verdade.]

263 [SUE: Eles lhe dão crédito por ser inteligente.]

${ }^{264}$ É o discurso competente, aliás, que garante a manutenção do status quo.
} 
remete ao passado, sendo sua paixão de infância. Ao revelar que está casada e com três filhos, Kate imediatamente faz seus comentários deixando claro o erro de pensar demais sobre os assuntos e deixando claro, consequentemente, o modo como pensa e age:

MOTHER [to Chris and George]: The trouble with you kids is that you think too much. $(p .60)^{265}$

MOTHER: And you didn't laugh enough. While you were getting mad about Fascism Frank was getting into her bed. (p.61) ${ }^{266}$

MOTHER: And now you're going to listen to me, George. You had big principles, Eagle Scouts the three of you. So now I got a tree, and this one, (indicating Chris) when the weather gets bad he can't stand on his feet. And that big dope (pointing to Lydia's house) next door who never reads anything

but Andy Gump has three children and his house paid off. Stop being a philosopher, and look after yourself. Like Joe was just saying... You move back here, he'll help you get set, and I'll find you a girl and put a smile on your face. $(\text { p.61 })^{267}$

Este "pensar demais" vai contra o princípio de "praticidade" tão comum à sociedade norte-americana. Primeiro Kate deixa claro que George perdeu Lydia porque ficou se preocupando demais com o Fascismo (esfera coletiva) enquanto deveria estar se preocupando com o fato de Frank estar na cama dela (esfera privada); depois Kate reforça a ideia de que George deve parar de ser um filósofo (e portanto parar de se preocupar com questões da humanidade) e deve cuidar de si mesmo. Cuidar de si mesmo, nas palavras de Kate, significa começar a trabalhar (com a ajuda de Joe), arranjar uma garota

\footnotetext{
${ }^{265}$ [MÃE: (para Chris e George) O problema com vocês jovens é que vocês pensam demais.]

${ }^{266}$ [MÃE: E você não riu o suficiente. Enquanto você se zangava com o Fascismo Frank estava indo para a cama dela.]

${ }^{267}$ [MÃE: E agora você vai me escutar, George. Você tinha grandes princípios, escoteiros, vocês três. E eu agora tenho uma árvore, e este aqui, (apontando Chris) quando o tempo fica ruim ele não consegue ficar em pé. E aquele grande idiota (apontando para a casa de Lydia) que nunca leu nada além de Andy Gump tem três filhos e a casa paga. Pare de ser filósofo e vá se cuidar. Como o Joe estava dizendo... mude de volta para cá, ele vai te ajudar a se estabelecer, e eu vou arranjar uma garota para você e colocar um sorriso na sua cara.]
} 
(Kate diz que o ajudará nisso) e colocar um sorriso no rosto. Aqui fica claro que Kate pretende agir como mãe de George ajudando-o a alcançar exatamente o padrão de felicidade que os valores tradicionais americanos reiteram continuamente: trabalho, dinheiro e família, obtendo-se assim, felicidade. Depois de ter revelado que Joe Keller havia sido responsável pelo fornecimento das peças defeituosas, Kate revela que suspeitava que no fundo o filho soubesse do fato:

MOTHER: I always had the feeling that in the back of his head, Chris... almost knew. I didn't think it would be such a shock. $(\text { p. } 74)^{268}$

JIM [gets up]: Chris would never know how to live with a thing like that. It takes a certain talent... for lying. You have it, and I do. But not him. (p.74) $)^{269}$

MOTHER: What do you mean... he's not coming back? $(p .74)^{270}$

JIM: Oh, no, he'll come back. We all come back, Kate. These private little revolutions always die (...). (p.74) 271

Esta passagem revela coisas interessantes: a percepção de Jim de que há pessoas que têm talento para mentir e outras não, mas, ao mesmo tempo o choque de Chris é entendido por Jim como uma "pequena revolução particular" que morrerá. Jim parece falhar no entendimento de que esta "private little revolution" não tem uma motivação privada, mas sim, coletiva. O que está em jogo na realidade não é a revolução e mudança de um sistema (como

\footnotetext{
${ }^{268}$ [MÃE: Eu sempre tive a impressão de que no fundo, Chris... quase sabia. Eu não achei que fosse ser um choque tão grande.]

${ }^{269}$ [JIM: (levanta-se) Chris jamais saberia viver com uma coisa dessas. É preciso um certo talento.... para mentir. Você tem esse talento, eu tenho esse talento. Mas ele não.]

${ }^{270}$ [MÃE: O que você quer dizer com... ele não vai voltar?']

271 [JIM: Oh, não, ele vai voltar. Todos nós voltamos, Kate. Essas pequenas revoluções particulares sempre morrem.]
} 
querem os marxistas, aliás), mas a conscientização após a queda ${ }^{272}$. Um aspecto interessante revelado através da personagem Jim e de outros vizinhos é que eles tinham consciência da verdade. O papel desses mesmos vizinhos, levando em conta a forma de tragédia, funciona como um coro. O coro é o elo entre o público e o privado, contudo, ao contrário do que se vê na tragédia clássica, este coro não denuncia, mas, compactua.

Joe Keller até os momentos finais da peça não se vê como responsável pelo estado de coisas e inclusive pede que Chris queime o dinheiro sujo ou o doe à caridade. Chris finalmente expõe a conexão intrínseca entre a esfera pública e a privada, ressaltando a importância da responsabilidade e da consciência. Chris diz ao pai e à mãe, respectivamente:

CHRIS: It's not what I want to do. It's what you want to do. $(p .82)^{273}$

CHRIS: Then what was Larry to you? A stone that fell into the water? It's not enough for him to be sorry. Larry didn't kill himself to make you and Dad sorry.

A consciência trágica adquirida por Joe Keller se revela em sua fala de que "todos eram seus filhos" e se concretiza com seu suicídio. A tragédia analítica que Miller escreveu com maestria trouxe não somente identificação e emoção, mas conhecimento. Ao jogar luzes em aspectos para os quais a sociedade fechava os olhos, Miller expõe a compreensão do tempo presente como ligado ao passado e sua dimensão é enriquecida com a estrutura trágica (Greco-Ibseniana) que conecta causa a efeito e privado ao coletivo. Sua crítica à guerra e ao lucro que se fez com ela às custas de vidas e à aparente situação idílica na qual se encontrava os Estados Unidos no pós-guerra, se

\footnotetext{
${ }^{272}$ Vale lembrar que uma das críticas da esquerda à peça era a de que não houve revolução e Chris Keller aceita herdar os negócios do pai. Miller esclarece dizendo que na vida real Chris não faria isso.

${ }^{273}$ [CHRIS: Não é o que eu quero fazer. É o que você quer fazer.]

274 [CHRIS: Então o que foi o Larry para você? Uma pedra que caiu na água? Não basta ele sentir muito. Larry não se matou para fazer você e o papai sentirem muito.]
} 
solidificou de maneira brilhante na criação de All My Sons. Seu próximo passo, desta vez para se posicionar contra o macarthismo, seria recorrer diretamente a Ibsen, o que traria para os Estados Unidos um An Enemy of the People revitalizado.

\section{CAPÍTULO II - CONSIDERAÇÕES ANALÍTICAS SOBRE AN ENEMY OF THE PEOPLE}

\section{MCCARTHY NA BROADWAY: A RESPOSTA DO TEATRO AMERICANO AOS INIMIGOS DA AMÉRICA}

O macarthismo é um período que marcou não somente a história literariodramatúrgica de Miller, mas também sua vida pessoal. Joseph McCarthy, o senador do Estado de Wisconsin, era somente a ponta do iceberg e teve seu auge como "caçador" dos vermelhos e subversivos nos anos 1950. É importante lembrarmos que dois momentos fortíssimos caracterizaram o red scare nos Estados Unidos: o primeiro de 1917 a 1920 e o segundo de 1940 a 1950. É correto afirmar que as raízes do "vigiar e punir" já estavam certamente fincadas na sociedade desde a chegada dos Pilgrims e a doutrina calvinista que ajudou a fundar os valores norte-americanos. Um outro período que intensificou tal prática (de vigiar e punir) foi aquilo que os historiadores convencionaram chamar de primeiro red scare: momento em que o governo decidiu criar uma série de leis, como por exemplo, o Espionage Act de 1917, que pretendia lidar com atitudes de espionagem, deslealdade e traição, e o Sedition Act de 1918, que procurava lidar com todas as atitudes que pudessem instigar a insubordinação, deslealdade, os motins ou a recusa de cumprir o dever militar. O segundo red scare, que nos interessa levar em conta em nossa pesquisa e que ficou conhecido como "A Era McCarthy", na verdade se iniciou quando, no dia 12 de Março de 1947, o então presidente Harry Truman lançou

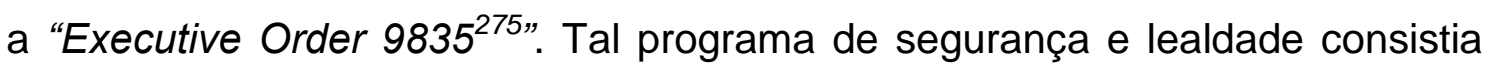

\footnotetext{
${ }^{275}$ WERTHEIM, Albert. The McCarthy Era and the American Theatre. In: Insurgency in American Theatre, Vol.34, May No. 2. The John Hopkins University Press, 1982.
} 
em uma lista que encorajava a dispensa, por parte de órgãos federais, de empregados que possivelmente estivessem associados ao comunismo. O que se viu nos anos seguintes, segundo Wertheim, com o uso da lista, com a caça às bruxas executadas pela HUAC e com as audiências presididas pelo senador McCarthy, solidificaram o poder de escrutínio e devastação daqueles que estavam no poder. Os efeitos dessa maquinaria da vergonha se materializaram em diversas peças de teatro que transformaram "o cínico em cênico", mas muitas infelizmente não receberam muita atenção ${ }^{276}$. O teatro americano dos anos 1950 não se silenciou perante o cenário histórico-político que o momento colocava:

Playwrights like Maxwell Anderson, Sidney Kingsley, Henry Denker, and Ralph Berkey clearly saw Communism and Communists as a threat to the United States and to American democracy. Others like Arthur Miller, Robert Ardrey, Lillian Hellman, James Thurber, and William Saroyan felt just as strongly that the fanatical attempt to expose Communists, former Communists and fellow travelers was more injurious to the American way of life than Communism itself. $^{277}$

A bipolaridade dramatúrgica que se apresentava refletia o momento de confusão que fracionava os americanos entre aderir à ideologia ou opor-se a ela. Tamanho era o poder retórico do chauvinismo proferido pelos "verdadeiros" defensores da democracia que via-se o que se achava impossível ser visto: intelectuais de renome sem manifestar suas opiniões ${ }^{278}$, venda de consciência, acusação desmedida etc. Algumas vozes sãs, contudo, enxergaram em tal período que a verdadeira ameaça à ideia de democracia era aquilo que estava sendo feito aos cidadãos americanos privando-os de liberdade e

\footnotetext{
${ }^{276}$ An Enemy of the People, como já dissemos, é uma das peças que encabeça o "elenco da negligência". Para se ter uma noção breve do que estamos falando, o livro "The Political Theater of Arthur Miller", de Jeffrey Mason, sequer menciona a peça supracitada, e, como lembramos, não é com 'The Crucible' que Miller começa sua ofensiva contra o macarthismo, mas, sim com a peça de Ibsen.

${ }^{277}$ WERTHEIM, Albert. op.cit., p.222. [Dramaturgos como Maxwell Anderson, Sidney Kingsley, Henry Denker, e Ralph Berkey viam claramente o comunismo e os comunistas como uma ameaça aos Estados Unidos e à democracia americana. Outros como Arthur Miller, Robert Ardrey, Lillian Hellman, James Thurber, e William Saroyan sentiram fortemente que a tentativa fanática em expor comunistas, excomunistas e camaradas-viajantes era mais nociva ao estilo de vida americano do que o próprio comunismo.]

${ }^{278}$ Este assunto fascinante é brilhantemente explorado por Richard Hofstadter em: "Anti-intellectualism in American life".
} 
individualidade. Miller inclusive fora tachado de 'Não-Americano ${ }^{279}$, pois se manteve fiel e coerente às coisas em que acreditava, sem render-se aos preceitos do momento. Ele, de certa forma, aproximou-se significativamente de uma das personagens mais emblemáticas de toda a sua dramaturgia, John Proctor:

Members of HUAC questioned Miller's donation of royalties to postwar relief efforts in Poland and in Czechoslovakia. They wondered why he had signed an amicus brief for the Hollywood Ten. They castigated him for calling the $\mathrm{FBI}$ "peeping Toms" who practiced "fascism, American style". 280

A relação de Miller com o macarthismo, portanto, foi marcada por extrema violência e retaliação. O fato que menciona os 'Hollywood Ten' acima diz respeito a um amicus curiae ${ }^{281}$ que Miller enviou à Suprema Corte enquanto esses aguardavam julgamento. Um dos episódios mais injustos resultantes do fanatismo anticomunista se deu quando Miller fora convidado para a estreia de The Crucible em Bruxelas em 1953, mas, teve seu passaporte negado. Tamanha foi a repercussão desse episódio, que inclusive Tennessee Williams, um dramaturgo que permanecia bastante reservado neste período, enviou uma carta de repúdio ao governo. A retórica abrasiva amplamente divulgada em todos os setores da vida americana durante o macarthismo reforçava sempre a ameaça interna e exemplos como os de Miller poderiam ser úteis para substanciar o discurso competente empregado pelas autoridades. Aqueles que trabalharam colaborando com as autoridades, como foi o caso de Kazan, "comprovavam" aos olhos do público que havia inimigos internos e que denunciá-los elevaria o status daquele que os delatou.

\footnotetext{
${ }^{279}$ Miller ficou conhecido como sendo um dramaturgo 'Un-American' por ousar criticar o próprio país e sua estrutura de pensamento e ação.

${ }^{280}$ FALK, Andrew J. Upstaging the Cold War: American dissent and cultural diplomacy, 1940-1960. University of Massachusetts Press, 2011, p.199. [Membros da HUAC questionaram a doação dos royalties de Miller para esforços de ajuda no pós-guerra na Polônia e na Chekoslováquia. Eles se perguntavam porque ele [Miller] havia assinado um depoimento [amicus curiae, 'amigo da corte'] para os "Dez de Hollywood". Eles o castigaram por ter chamado o FBI de "bisbilhoteiros"que praticavam "fascismo, no estilo americano".]

${ }^{281} \mathrm{O}$ termo, de origem latina, significa "amigo da corte" e refere-se a uma intervenção de terceiros (órgãos, entidades e indivíduos) em uma questão jurídica para servir como fonte de conhecimento em assuntos inusitados, inéditos, difíceis ou controversos, ampliando a discussão antes da decisão final. Para Fredie Didier Jr. (2003) o amicus "é o auxiliar do juízo, com a finalidade de aprimorar ainda mais as decisões proferidas pelo Poder Judiciário" e cuja função histórica é chamar a atenção da corte para fatos ou circunstâncias que poderiam não ser notados.
} 
Em seu emblemático livro "The Paranoid Style in American Politics and Other Essays" o ilustre historiador norte-americano Richard Hofstadter analisa como o discurso político (e suas ações) podem ser moldados com base em indivíduos com comportamentos singulares que defendem ideologias ligadas às suas patologias. O delírio religioso-político visto em Salém, uma pequena comunidade em 1620, torna-se uma política oficial de Estado à qual muitos se "convertem". Em 1950, a paranoia contra os inimigos internos teve sua adesão facilitada com a mídia e as audiências televisionadas e refletia a paranoia dos americanos em geral, mas, principalmente da Direita e dos Republicanos. Hofstadter comenta que:

Part of McCarthy's strength lay in his ability to combine a mass appeal with a special appeal to a limited stratum of the upper classes. (...) McCarthy was able to win considerable support from the middle and upper ranks of society, mobilizing Republicans who had never accepted the changes brought by the New Deal and whose rage at the long exclusion of the party from presidential power was reaching a peak. There is evidence also that McCarthy had a special appeal to the postwar newly rich. Most prophetic too of the future of the right wing was his appeal for fundamentalist-oriented Protestants, who now took a significant place along with their Catholic counterparts. ${ }^{282}$

Vale ressaltar que o fenômeno do macarthismo se estendeu muito além da Direita. Durante o ápice do período, entre 1953 e 1954, não havia sequer uma enquete em que o índice de aprovação do senador de Wisconsin fosse inferior a 34\%, e em janeiro de 1954 , esse índice subiu para 50\%. Tal resultado aponta para uma adesão geral do público que voluntaria ou involuntariamente cedia às manipulações daquele período vergonhoso ${ }^{283}$. Lillian Hellman com sua

\footnotetext{
${ }^{282}$ HOFSTADTER, Richard. The Paranoid Style in American Politics and Other Essays. Vintage Books: New York, 2008, p.69-70. [Parte da força de McCarthy estava em sua habilidade em combinar um apelo de massa com um apelo especial a um estrato limitado das classes mais altas. (...) McCarthy foi capaz de ganhar um apoio considerável da classe média e escalas mais altas da sociedade, mobilizando Republicanos que nunca tinham aceito as mudanças trazidas pelo 'New Deal' e cuja raiva pela longa exclusão do partido do poder presidencial, estava atingindo um pico. Há também evidências de que McCarthy tinha um apelo especial para os novos ricos do pós-guerra. Mais profético também em relação ao futuro da Direita, era seu apelo para Protestantes de orientação fundamentalista, que agora assumiram um lugar de destaque, juntamente com sua contraparte, a Católica.]

${ }^{283} \mathrm{O}$ jornalista Edward R. Murrow ficou conhecido por fazer uma série de reportagens que corajosamente questionavam a lógica das audiências e a maneira como eram conduzidas por Joseph McCarthy, o que ajudou no seu desprestígio e sua iminente derrocada. O filme "Boa Noite e Boa Sorte (2005)", com
} 
famosa frase "I cannot and will not cut my conscience to fit this year's fashion" parece compreender inteiramente em que solo está apoiada a política delirante (e portanto patológica) do momento. O açoite à liberdade e à privacidade também não enfraqueceram as convicções e a consciência de Miller que trilha um caminho brilhantemente corajoso tanto como cidadão como dramaturgo. É justamente An Enemy of the People o primeiro passo da carreira dramatúrgica antimacarthista de Arthur Miller, e é com Ibsen que ela se abre. É trazendo o furacão para o olho de outro furacão que Miller reavivará Ibsen na América e colocará no palco a fúria e o poder que a peça do norueguês tem e à qual os Estados Unidos terão que enxergar.

\section{READAPTANDO IBSEN NA AMÉRICA: TRAZENDO O FURACÃO PARA O OLHO DO FURACÃO}

An Enemy of the People 284 , de Arthur Miller, é uma peça que carrega consigo um significado imensurável em primeiro lugar por ter sido originalmente escrita por Henrik Ibsen em 1882 em dano-norueguês, e por ter sido a primeira peça ${ }^{285}$ a tocar no tema do macarthismo. A ideia de readaptar a peça original de Ibsen partiu do diretor Robert Lewis e do casal de atores Fredric March e Florence Eldridge. Todos encontravam-se em um período sombrio da história norte-americana em que perseguições aos "vermelhos" eram um ato patriótico incentivado pelo governo.

direção de George Clooney, retrata bem o papel de Murrow, assim como o premiado documentário "The Edward R. Murrow: The McCarthy Years (2005)", produzido por Roger Birnbaum.

\footnotetext{
${ }^{284}$ A peça foi adaptada na versão de Miller para a televisão em 1966, com direção de Paul Bogart; tornouse um filme em 1978, com direção de George Schaeffer e estrelando Steve McQueen. Sob o título de 'Ganashatru', um outro filme (na versão de Ibsen) é adaptado em 1989, com direção de Satyajit Ray e finalmente em 2005 tem sua versão norueguesa, sob o título de 'En Folkefiende', dirigido por Erik Skjoldbjarg (também na versão de Ibsen).

${ }^{285}$ Quando se fala de macarthismo em Arthur Miller, os críticos comumente comentam peças como The Crucible (1952), A View from the Bridge (1955) e After the Fall (1964), deixando de lado, como já frisamos, An Enemy of the People (1951) que foi sua primeira peça a lidar com o tema.
} 
In order to further restrict potential subversives among the artistic and intellectual community, a blacklisting system, by which anyone even rumored to have "Red" sympathies would be refused work or prevented from displaying their art, came into creation. Unfortunately, by the time that fears of communist expansion were assuaged, and the committee's bullying tactics and McCarthy's own self-aggrandizing agenda were finally exposed, many people had lost careers, reputations, and even their sanity or life ${ }^{286}$.

Algumas pessoas do teatro e do cinema admitiram para o Comitê de Atividades Antiamericanas (HUAC) terem sido simpatizantes do socialismo, inclusive indicando nomes de pessoas que possivelmente flertassem ou tivessem flertado com o comunismo em outros tempos. Este foi o caso de Elia Kazan, o importante diretor de teatro e cinema que, além de ter dirigido All My Sons, era também amigo de Miller. A conduta de Kazan veio a abalar a até então forte amizade de Miller $^{287}$, que se recusou a cooperar quando foi chamado a depor, assim como os Hollywood $T^{288}{ }^{28}$. É neste momento que o casal Fredric March e Florence Eldridge convida Miller a fazer a adaptação de An Enemy of the People, de Henrik Ibsen. O casal havia sido incluído na lista de suspeitos de simpatia com o comunismo, e perdera trabalhos importantes na indústria do entretenimento e planejava como resposta encenar a peça do norueguês:

\footnotetext{
${ }^{286}$ ABBOTSON, Sue. C. W. Student Companion to Arthur Miller. Greenwood Press. Westport, CT: 2000. p.8. [Para restringir ainda mais os subversivos em potencial entre a comunidade artística e intellectual, um sistema de lista negra, pelo qual qualquer um que fosse suposto em ter simpatias "vermelhas" teria trabalho negado ou seria impedido de mostrar sua arte, entrou em criação. Infelizmente, no momento em que os medos da expansão comunista foram amenizados, e táticas de intimidação do comitê e a agenda de auto-engrandecimento de McCarthy foram expostas, muitas pessoas tinham perdido carreiras, reputações, e até mesmo sua sanidade ou vida.]

${ }^{287}$ É importante frisar que Miller não teve seu nome incluído na 'lista negra', mas foi acusado de desacato por não colaborar com as autoridades quando foi chamado a depôr. Seu argumento era de que responderia por seus atos, mas não pelos dos outros, não podendo, assim, citar ou dar nomes de possíveis pessoas que eram e/ou estavam ligadas ao comunismo. Em Agosto de 1958, contudo, é absolvido.

${ }^{288}$ Os 'Hollywood Ten' ficaram conhecidos por terem sido nomeados dentre roteiristas, diretores, atores e músicos para que fossem boicotados e para que lhes fosse negado emprego. A lista não somente arruinou a carreira de muitos, mas, ajudou a moldar o sentimento anticomunista. Os dez nomeados foram: $\underline{\text { Alvah }}$ Bessie (roteirista), Herbert Biberman (roteirista e diretor), Lester Cole (roteirista), Edward Dmytryk (diretor), Ring Lardner Jr (roteirista), John Howard Lawson (roteirista), Albert Maltz (roteirista),

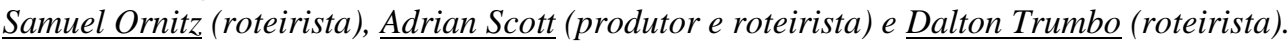


We took the idea to Arthur Miller in the first place. It seemed to us that a lot of people were being tarred and feathered, when the only crime they were guilty of was trying to clean up the sewers ${ }^{289}$.

Vendo no protagonista da peça uma situação similar àquela em que se encontravam, o casal decide encenar a peça que reflete a situação em que todos são acusados por suspeita de ameaça ao bem-estar da sociedade, por uma histeria em massa. Apesar de ter tido liberdade de trabalhar neste período conturbado, Miller perdeu dois contratos de filmes. Este período sombrio da história norte-americana revelou a linha tênue em que se apoiam as relações humanas, fazendo que os melhores amigos se tornassem os piores inimigos, se fosse o caso de salvar suas próprias reputações e carreiras. Este panorama fica claro em The Crucible, escrita em 1956, que faz um paralelo entre a paranoia americana anticomunista dos anos 1950 e as condenações de bruxaria de 1692, em Salém, na qual vimos expostas a denúncia pública de pessoas inocentes e a manipulação da psique coletiva. Hollywood certamente não aprovava o retrato da América que Miller ${ }^{290}$ fazia, tanto que:

(...) Plans to produce The Hook ${ }^{291}$ were shelved, and the American Legion threatened to picket the film of Death of a Salesman. To soothe opposition, the production company, Columbia, offered to show Death of a Salesman accompanied by a film short supporting American businessmen and explaining how Loman was not a typical salesman. ${ }^{292}$

\footnotetext{
${ }^{289}$ PETERSON, Deborah C. Fredric March: Craftsman First, Star Second. Greenwood Press, 1996, p.172-73. [Nós levamos a ideia a Arthur Miller logo de cara. Parecia-nos que várias pessoas estavam sendo apontadas e expostas, quando o único crime do qual elas eram culpadas era de tentar limpar os "esgotos".]

${ }^{290}$ Miller menciona que o fato de ele criticar problemas que o país e sua estrutura colocavam, o tornaram um subversivo em potencial. Quando chamado a depor perante o Comitê, Miller diz em Timebends (p.323): "Among the questions asked me by the chairman of that committee was, 'Why do you write so sadly about this country?' It is truly a Stalinist question, if you will, and there are millions of Americans that share the chairman's feelings". [Dentre as perguntas que me foram feitas pelo presidente daquele comitê foi: 'Por que você escreve tão tristemente sobre este país?' É uma pergunta verdadeiramente stalinista, se você me permite (dizer isso), e há milhões de americanos que compartilham os sentimentos do presidente.]

${ }^{291}$ The Hook trataria da corrupção nos sindicatos das docas de Brooklin. Mas Harry Cohn, presidente da Columbia Pictures em Hollywood, disse que só faria o filme se os corruptos fossem trocados por comunistas.

${ }^{292}$ ABBOTSON, Sue. op.cit., p.10. [Planos para produzir "The Hook" foram engavetados, e a 'Legião Americana' ameaçou boicotar o filme 'A Morte de um Caixeiro Viajante'. Para acalmar a oposição, a produtora Columbia ofereceu-se para mostrar 'A Morte de um Caixeiro Viajante' acompanhado de um curta-metragem que apoiasse os empresários americanos e explicasse como Loman não representava o típico caixeiro.]
} 
Miller se opôs à proposta da Columbia, ameaçando processá-los. O filme fora lançado, mas, seu sucesso foi pequeno, já que o clima político de então não era o mais apropriado para se aceitar críticas ao sistema de valores americanos. Trabalhando a partir de uma tradução literal do norueguês ${ }^{293}$, Miller adapta An Enemy, que estreou no Broadhurst Theater, no dia 28 de Dezembro de 1950 , e teve trinta e seis performances ${ }^{294}$ com resultados controversos:

(...) the play didn't have the effect we thought it would. It was quickly taken up by the people in the audience, both left and right, and on closing night there were police lines out front ${ }^{295}$.

Esta característica, aliás, foi bastante comum às peças de lbsen. O potencial incendiário de suas peças ${ }^{296}$ levou a críticas massivas de todos os lados e inclusive manifestações que envolviam violência. Silva menciona que:

(...) O Inimigo do Povo já foi interpretado como proclamação subversiva, como apologia da ditadura do proletariado, como manifesto fascista, como profissão de fé democrática ou antidemocrática. ${ }^{297}$

\footnotetext{
${ }^{293}$ Um fato bastante curioso descoberto em uma palestra à qual assisti em Junho de 2011 proferida pelo Prof. Dr. Francis Henrik Aubert, ressaltou que Ibsen escrevia suas peças em dano-norueguês, e não em norueguês (apesar de Ibsen ser norueguês). Entretanto, as traduções para inglês, francês, espanhol e português (de Portugal) normalmente partem de uma versão já traduzida para norueguês. A palestra aconteceu em 10 de Junho de 2011, na FFLCH, sob o título de: "Henrik Ibsen: é assim que se diz? A tradução contemporânea da dramaturgia de Henrik Ibsen exemplificada em Hedda Gabler e Um Inimigo do Povo: de Christiania a Lisboa passando por Piratininga: negociando as dizibilidades nas duas pontas".

${ }^{294}$ Ao final do ano Fredric March recebera o 'Crusade for Freedom Certificate' por seu esforço altruísta em ajudar mentes e almas livres sob tirania comunista. Além disso, March também fora citado pelos National Collegiate Players por seu trabalho excepcional em An Enemy.

${ }^{295}$ PETERSON, Deborah C. op.cit., p.173. [(...) a peça não teve o efeito que nós achávamos que teria.

Ela foi rapidamente pega pelas pessoas na plateia, ambas da direita e esquerda, e na noite de encerramento havia linhas de policiais do lado de fora.]

${ }^{296} \mathrm{Um}$ fato curioso é que o acesso a Ibsen na Inglaterra se deu majoritariamente por mulheres. An Enemy of the People, por exemplo, foi traduzido por Eleanor Marx-Aveling, filha de Karl Marx.

${ }^{297}$ SILVA, Jane Pessoa. op.cit., p.273, Vol II.
} 
Em uma apresentação de An Enemy (aliás, a primeira de lbsen a ganhar uma interpretação simbolista), a peça tornou-se ainda mais polêmica com uma apresentação explicitamente anarquista. A estreia da peça fora precedida por uma conferência dada por Laurent Tailhade (poeta libertário) que ressaltou a importância da revolta contra "le père, le patron e la patrie". Ao final do espetáculo, vaias e aplausos trovejaram com o público que participou ativamente e o tumulto iniciado ganhou as ruas resultando em prisão, perseguição e até mesmo em deportação.

Com relação a Miller, as críticas, contudo, haviam sido positivas. De acordo com Brooks Atkinson, no New York Times:

An enormously rousing performance. The breadth and volume that are overwhelming ${ }^{298}$.

Antes do início da peça, no prefácio, Miller faz alguns esclarecimentos importantes. Ele aponta que a palavra "adaptação" the parece um pouco desagradável. $O$ termo, ele nos diz, parece significar que um outro escritor se intrometeu em um universo sagrado de um autor e reorganizou as coisas sem permissão. Ainda criticando o termo, Miller diz que muitas vezes a adaptação é uma desculpa para um dramaturgo não criar suas próprias peças ${ }^{299}$. Ele, contudo, se exclui de ambas as definições. Ao esclarecer o que tentara fazer com An Enemy of the People, Miller menciona a importância dramatúrgicohistórica de Ibsen e sua profunda fonte de força ${ }^{300}$. O caráter revolucionário das peças de lbsen é conhecido por críticos teatrais e não teatrais. Miller menciona que a força do "pai do drama moderno" está no fato de que:

\footnotetext{
${ }^{298}$ PETERSON, Deborah C. op.cit., p.174. [Um desempenho extremamente empolgante. Amplitude e volume que são esmagadores.]

${ }^{299}$ Miller parece mostrar um claro respeito pela ideia de autoria como propriedade intelectual, posição que diverge da postulada por Brecht.

${ }^{300} \mathrm{O}$ dramaturgo e diretor de cinema britânico Christopher Hampton também adaptou a peça de Henrik Ibsen e no prefácio de sua peça menciona que 'An Enemy' fora a primeira peça à qual assistiu e diz: [(...) I attributed to this experience the birth of my serious interest in theatre; no doubt something of an oversimplification, but at the very least, it was the first of a long series of occasions when I have been inspired and sustained by the rigorous, uncomfortable, but profoundly humane genius of Ibsen.] p.v.

[(...) Eu atribuí a essa experiência o nascimento do meu interesse sério pelo teatro; sem dúvida algo de uma extrema simplificação, mas pelo menos, foi a primeira de uma longa série de ocasiões em que eu estive inspirado e sustentado pelo gênio rigoroso, desconfortável, mas profundamente humano de Ibsen.]
} 
It is his insistence, his utter conviction, that he is going to say what he has to say and that the audience, by God, is going to listen ${ }^{301}$.

Uma das características mais interessantes de lbsen, e que condiz profundamente com a própria filosofia teatral de Miller, é a de que suas peças

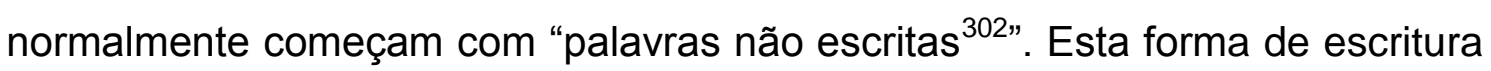
opõe-se, em primeiro lugar, à forma tradicional de se fazer teatro e, em segundo lugar, à concepção escapista e de cunho de entretenimento pela qual o teatro é muitas vezes entendido. Este caminho Ibseniano atravessa o portal do entretenimento quebrando regras clássicas e desmantelando preceitos inerentes ao teatro enquanto empreendimento comercial. Uma voz como a de Ibsen se encontra rouca (quando não, muda) e isto cada vez mais ganha obscuridade e, como diz Miller: uma obscuridade respeitosa ${ }^{303}$. O termo respeitoso é bastante curioso, pois o respeito a lbsen é praticamente geral hoje em dia (ao contrário do que ocorria em sua própria época), visto que ele é citado por muitos como o "pai do teatro moderno". Este título o coloca como um autor canônico, mas, que cai na obscuridade por existirem cada vez mais críticos (literários e não-literários) tachando suas peças de datadas ou ultrapassadas $^{304}$. Certamente suas peças, assim como as de outros dramaturgos, situam-se histórica, política e culturalmente em um contexto específico, mas, cujo conteúdo e forma transcendem a ideia de um período cronologicamente marcado. A incapacidade de enxergar conexões e estabelecer relações é um fenômeno que se encontra em metástase tanto em civilizações ocidentais quanto orientais. A análise de coisas que não se mostram ligadas ao contexto imediato e prático torna-se um exercício difícil,

\footnotetext{
${ }^{301}$ MILLER, Arthur. An Enemy of the People. New York: Penguin Books, op.cit., p.7. [É sua insistência, sua convicção absoluta de que ele vai dizer o que ele tem a dizer e que o público, por Deus, vai ouvir.]

${ }^{302}$ Miller exemplifica em seu prefácio com 'Now listen here!' e diz que tais palavras implodem a parede do entretenimento e mostram a que veio seu teatro: a secar a fraude, as fórmulas e preceitos sob os quais se apoia o teatro enquanto atividade comercial.

${ }^{303}$ MILLER, Arthur. An Enemy of the People. op. cit, p.7. "In recent years Ibsen has fallen into a kind of respectful obscurity that is not only undeserved but quite disrespectful of culture - and a disservice to the theater besides". [Em anos recentes Ibsen caiu em um tipo de obscuridade respeitosa que não somente é injusta, mas muito desrespeitosa da cultura - além de ser um desserviço ao teatro.]

${ }^{304}$ Jane Pessoa da Silva menciona em sua dissertação de mestrado que as peças de Ibsen eram consideradas por muitos como datadas e que isto foi, parcialmente, uma vantagem no período da ditadura visto que os artistas não teriam problemas com a censura ao levarem para o palco um "autor ultrapassado das prédicas libertárias" (Vol I, p.69).
} 
complexo e aparentemente inútil. $\mathrm{O}$ apagamento da história, tão comum às sociedades de maneira geral, causa certa dificuldade em encontrar relevância e/ou importância em um autor cuja essência é desestruturante (como é o caso de lbsen). Arthur Miller, sendo um leitor e admirador de Ibsen, decide trabalhar com An Enemy of the People justificando que:

(...) it has become the fashion for plays to reduce the "thickness" of life to a fragile facsimile, to avoid portraying the complexities of life, the contradictions of character, the fascinating interplay of cause and effect that have long been part of the novel. And I wished also to buttress the idea that the dramatic writer has, and must again demonstrate, the right to entertain with his brains as well as his heart. It is necessary that the public understand again that the stage is the place for ideas, for philosophies, for the most intense discussion of man's fate ${ }^{305}$.

Fica evidente a importância de Ibsen não somente para entendimento/discussão das questões dramatúrgicas que se colocam para aqueles que estudam teatro, como para o espectador que poderá enxergar que o palco é o lugar não somente do entretenimento, mas também das ideias. Quando Miller adaptou a peça de Ibsen nos Estados Unidos, certamente seu objetivo histórico-político (além de reavivar Ibsen na América) foi o de resgatar o papel do teatro no sentido de atender à necessidade de pensar, de analisar, de observar e de discutir as questões que se colocavam naquele momento. $O$ contexto por trás e dentro de An Enemy of the People é o do macarthismo, e isto tem um peso maior ainda quando Miller refuncionaliza a peça de lbsen dentro do contexto persecutório dos anos de 1950. Miller afirma que o tema central da peça é a vida social contemporânea:

Simply, it is the question of whether the democratic guarantees protecting political minorities ought to be set aside in time of crisis. More personally, it is

\footnotetext{
305 MILLER, Arthur. An Enemy of the People, op.cit., p.8. [(...) Tornou-se a moda para peças reduzir a "espessura" da vida de um fac-símile frágil, para evitar retratar as complexidades da vida, as contradições do personagem, o jogo fascinante de causa e efeito que tem há muito tempo sido parte do romance. E eu queria também reforçar a ideia de que o escritor dramático tem, e deve voltar a demonstrar, o direito de entreter com seu cérebro, assim como com seu coração. É necessário que o público entenda mais uma vez que o palco é o lugar para ideias, para filosofias, para a mais intensa discussão sobre o destino do homem.]
} 
the question of whether one's vision of the truth ought to be a source of guilt at a time when the mass of men condemn it as dangerous and devilish lie ${ }^{306}$.

Ainda segundo Miller, este é um dos temas mais duradouros de lbsen, pois jamais existiu ou existirá uma sociedade organizada capaz de aprovar calmamente um indivíduo que se oponha ao mainstream. No momento do macarthismo nos Estados Unidos opor-se à ideologia vigente e imposta pelo governo e pela população (doutrinada e incentivada pelo governo) seria um ato proibido e condenável.

Quando Henrik Ibsen escreveu An Enemy, teve inspiração em uma notícia sobre um cientista húngaro que descobriu que a rede de fornecimento de água estava poluída e havia sido ridicularizado por isto. Há diversas especulações com relação à motivação do norueguês para a escritura da peça. An Enemy, diz a maioria dos críticos, é uma resposta à crítica liberal e ao público que o criticaram duramente por causa de Espectros (1881). Conde Prozor, contudo, informa que cronologicamente isso seria impossível porque não houve intervalo suficiente entre uma peça e outra para que o clamor se fizesse sentir tão forte. Otto Maria Carpeaux, o conhecido crítico literário, acredita que An Enemy tenha nascido como uma crítica a seu amigo e rival literário Bjørnson. Silva ${ }^{307}$ nos diz que a segunda opção parece fazer mais sentido visto que Ibsen pretendia derrubar toda a plataforma reformista do partido liberal norueguês, do qual Bjørnson era uma das bandeiras. Acreditamos, contudo, que ambas as explicações fazem sentido quando levamos em conta a afirmação do próprio dramaturgo que, em correspondência com Brandes (seu editor) em 8 de Janeiro de 1882, diz o seguinte:

"These leaders of the people who speak and write of freedom of action and thought, and at the same time make themselves the slaves of the supposed opinions of their subscribers. I receive more and more corroboration of my conviction (...) that there is something demoralizing in engaging in politics and in joining parties. It will never, in any case, be possible for me to join a party that

\footnotetext{
${ }^{306}$ Ibidem, p.8. [Simplesmente é a questão de se as garantias democráticas que protegem minorias políticas devem ser deixadas de lado em tempo de crise. Mais particularmente, é a questão de se a visão de alguém da verdade deve ser uma fonte de culpa em um período no qual a maioria dos homens condena esta visão como uma mentira perigosa e diabólica].

${ }^{307}$ SILVA, Jane Pessoa. op.cit., p.330-331 - Vol II.
} 
has the majority on its side. Bjørnson says: 'The majority is always right.' And as a practical politician he is bound, I suppose, to say so. I, on the contrary, must of necessity say: 'The minority is always right. ${ }^{.308}$

A menção aos líderes do povo que falam e escrevem (críticos) sobre liberdade de ação e pensamento, é vista de maneira explícita nas figuras de Hovstad, Billing e Aslaksen (que trabalham para a imprensa liberal). Além disso, Ibsen expressa sua opinião contrária à de Bjørnson e isso também entra de maneira direta na peça, quando Stockmann diz que a minoria está sempre certa. Miller parece ir mais afundo do que Ibsen contextualizando e explicando que a 'minoria está certa quando fizer o certo', que será explorado adiante em nossa análise, não deixando sugerir a ideia de que por definição a minoria está sempre certa. É necessário agir, para saber se o certo está em prática ou não. Independentemente da motivação do dramaturgo para ter escrito a peça em questão, há de se considerar mais algumas palavras de lbsen novamente a Brandes, escritas em 12 de Junho de 1883:

As regards myself at least, I am quite aware of such unceasing process. At the point where I stood when I wrote each of my books there now stands a tolerably compact crowd; but I myself am no longer there. I am elsewhere; farther ahead,

I hope. ${ }^{309}$

Henrik Ibsen, como o homem inquieto que era, buscou se utilizar do teatro de ideias (não o simples teatro de entretenimento) para afirmar a possibilidade de se pensar, de se questionar, de refutar, qualquer verdade que esteja instituída

\footnotetext{
${ }^{308}$ MOSES, Montrose Jonas. (2013). Henrik Ibsen: The Man and His Plays. Hong Kong: Forgotten Books, 2013 (Original work published 1908), p. 381-2 [Esses líderes do povo que falam e escrevem sobre liberdade de ação e pensamento, e ao mesmo tempo tornam-se escravos das supostas opiniões de seus assinantes. Eu recebo mais e mais corroboração da minha convicção (...) de que há algo desmoralizante em engajar-se na política e em unir-se a partidos. Nunca será, em qualquer caso, possível para mim que eu me junte a um partido que tem a maioria do seu lado. Bjørnson diz: "A maioria está sempre certa." E, como um político prático ele é obrigado, eu suponho, a dizer. Eu, ao contrário, preciso necessariamente dizer: "A minoria está sempre certa".]

${ }^{309}$ HARALDSSON, Róbert H. Plotting against a Lie: a reading of Ibsen's An Enemy of the People. University of Iceland Press, 2004, p.31. [Quanto ao que diz respeito a mim, pelo menos, estou bastante ciente de tal processo incessante. No ponto onde eu estava quando escrevi cada um dos meus livros, agora existe uma multidão razoavelmente compacta, mas eu mesmo não estou mais lá. Estou em outro lugar; mais à frente, eu espero.]
} 
como absoluta e inescapável. Quando Miller justifica sua escolha em adaptar a peça, utiliza-se do que considerou que fosse o impulso de lbsen:

(...) it seems beyond doubt that lbsen meant above and beyond all else to defend his right to stand "at the outpost of society", alone with the truth, and to speak from there to his fellow men ${ }^{310}$.

Ao adaptar An Enemy, Miller corajosamente coloca nos palcos a mensagem de Stockmann: a de que é necessária uma intervenção no estado vigente da estrutura de vida da sociedade, mas, esta intervenção é frustrada pela prevalência dos interesses econômicos e políticos ${ }^{311}$. Bauman diz sabiamente que:

A cooperação entre Estado e mercado no capitalismo é a regra; o conflito entre eles, quando acontece, é a exceção. Em geral, as políticas do Estado capitalista, "ditatorial" ou "democrático", são construídas e conduzidas no interesse e não contra o interesse dos mercados; seu efeito principal (e intensional, embora não abertamente declarado) é avalizar/permitir/garantir a segurança e longevidade do domínio do mercado. ${ }^{312}$

A situação em An Enemy of the People é exatamente esta: o lucro da cidade se vê ameaçado e a política de Estado defende ferozmente que 0 balneário seja mantido e que não há risco algum em suas águas.

A peça atua com base na analogia: é a analogia o princípio formal que aciona o mecanismo crítico relativo ao macarthismo e à chamada caça às bruxas. A urgência da denúncia e da crítica que se apresenta no enredo de

\footnotetext{
${ }^{310}$ MILLER, Arthur, An Enemy of the People. op.cit., p.9. [(...) Parece não haver dúvidas de que Ibsen queria acima e além de tudo defender seu direito de estar "em um lugar avançado da sociedade", sozinho com a verdade, e falar de lá para os seus semelhantes.]

${ }^{311}$ Esta é, em todos os sentidos, uma das características mais sobressalentes do 'Totalitarismo Invertido', postulado por Sheldon Wolin. No Totalitarismo Invertido, a figura do ditador e líder demagogo, é substituída pela onipresença da corporação; A estátua de Hitler, Mussolini ou Stalin, dá lugar aos símbolos das grandes marcas; A constituição, dá espaço às leis econômicas escritas pelos donos de ações; Os departamentos estatais de imprensa e propaganda, são substituídos por uma comunicação de massa que atua a serviço da manutenção do status quo e a censura prévia, dá lugar a uma mídia privada que bloqueia e elimina qualquer tentativa de crítica verdadeiramente transformadora. $\mathrm{O}$ interessante postulado deste filósofo político encontra-se em: WOLIN, Sheldon. Democracy Incorporated: Managed Democracy and the Specter of Inverted Totalitarianism. Princeton University Press, New Jersey, 2008.

${ }^{312}$ BAUMAN, Zygmunt. Capitalismo Parasitário. Zahar: Rio de Janeiro, 2010, p.31.
} 
Ibsen, é refuncionalizada para o contexto norte-americano, com Miller. Em The Crucible essa mesma questão se apresenta: John Proctor não endossava 0 princípio da teocracia puritana de Salém, mas acreditava ser possível manterse à parte, isolado e sem se manifestar como havia feito até ser denunciado por Abigail Williams. Quando a denúncia faz dele e de sua mulher Elizabeth réus, Proctor descobre o quanto se enganara e que o sistema fez deles vítimas. No sentido dramatúrgico a adaptação de Miller se encontrava na contramão de muitas outras peças que estavam sendo produzidas na época. A matéria dramatúrgica representada na peça de lbsen, que serve de base a Miller para a sua reescritura, coloca o teatro norte-americano em um momento avançado tanto no plano formal quanto no do conteúdo.

Miller fez algumas mudanças importantes para que a peça se adaptasse à realidade norte-americana e que serão comentadas no decorrer da análise. Antes de passarmos à análise da peça, é necessário fazer três pequenas observações. A primeira diz respeito à mudança na linguagem da peça:

I set out to transform his language into contemporary English. Working from a pidgin-English, word-for-word rendering of the Norwegian, done by Mr. Lars Nordenson, I was able to gather the meaning of each speech and scene without the obstruction of any kind of English construction ${ }^{313}$.

Quando Miller se refere a um significado coletado de um inglês traduzido "palavra por palavra" e transformado em inglês contemporâneo, isto se soma à sua concepção dramatúrgica de tratar o homem comum ${ }^{314}$. A proximidade da linguagem (bastante informal e oralizada, quando adaptada por Miller) traz 0 contexto da peça mais perto da realidade norte-americana. A segunda observação que se faz necessária é no que diz respeito à uma grande polêmica que a peça de Ibsen causou. Na cena original em que Dr. Stockmann está fazendo sua defesa e explicando o porque de as águas estarem poluídas,

\footnotetext{
${ }^{313}$ MILLER, Arthur. An Enemy of the People. Op.cit., p.11. [Eu me propus a transformar sua linguagem em Inglês contemporâneo. Trabalhando a partir de um Inglês traduzido palavra por palavra capitulado do norueguês, feito pelo Sr. Lars Nordenson, eu fui capaz de reunir o significado de cada palavra e cena sem a obstrução de qualquer tipo de construção do Inglês.]

${ }^{314}$ Como já mencionado, este termo/conceito é bastante discutido em seu ensaio: "Tragedy and the Common Man". MILLER, Arthur. Tragedy and the Common Man. The New York Times. 27/02/1949. In: Martin, Robert A.; Centola, Steven R.
} 
há um discurso feito por ele (e por lbsen) que pode sugerir a ideia de fascismo. Miller menciona que:

(...) Dr. Stockmann makes a speech in which he turns to biology to prove that there are indeed certain individuals "bred" to a superior apprehension of truths and who have the natural right to lead, if not, govern the mass. ${ }^{315}$

Em 1885 (um ano após a producção de An Enemy), enquanto visitava Christiania, Ibsen se dirigiu a Drontheim, um clube de trabalhadores, para esclarecer o mal entendido. Em parte, o norueguês disse:

"Democracy alone cannot solve the social question. An element of aristocracy needs to be infused into our life. Of course, I do not mean the aristocracy of birth, or of the purse, or even the aristocracy of intellect. I mean the aristocracy of character, of will, of mind. That only can free us." ${ }^{316}$

É clara e aberta a posição de lbsen de que a democracia por si só não garante que decisões éticas e responsáveis sejam tomadas. Daí seu apelo à 'aristocracia', mas aquela do caráter que deve firmar-se e estabelecer-se como um posicionamento indissolúvel. Contudo, Miller levando em conta experiências trazidas com a Shoah e com a questão do racismo contra os negros de seu país, decide remover a fala em questão. A terceira e última observação diz respeito à estrutura da peça. O autor de All My Sons comenta que:

The original has a tendency to indulge in transitions between scenes that are themselves uninteresting, and although as little as possible of the original construction has been changed and the play is exactly as it was, scene for scene, I have made each act seem of one piece, instead of separate scenes. And my reason for doing this is simply that the tradition of Ibsen's theater

\footnotetext{
${ }^{315}$ MILLER, Arthur. An Enemy of the People. Op.cit., p.9-10. [(...) Dr. Stockmann faz um discurso no qual se volta para a biologia para provar que de fato existem certos indivíduos "criados" para uma apreensão superior de verdades e que têm o direito natural de conduzir, se não, governar a massa.] ${ }^{316}$ MOSES, Montrose Jonas. Op.cit., p. 383. ["A democracia por si só não consegue resolver a questão social. Um elemento de aristocracia precisa ser infundido em nossa vida. Naturalmente, não me refiro à aristocracia de nascimento, ou da econômica, ou até mesmo a aristocracia do intelecto. Quero dizer a aristocracia de caráter, de vontade, de alma. Só isso pode nos libertar.]
} 
allowed the opera-like separation of scenes, while ours demands that the audience never be conscious that a "scene" has taken place at all ${ }^{317}$.

Miller busca com isso reduzir o efeito teatral no qual a performance se divide em cenas. Quando o autor de Death of a Salesman nos diz que nosso público atual exige que o público não esteja consciente de que uma cena foi feita, ele procura 'desteatralizar' aproximando a peça do público. O uso de uma piada, que será mencionada posteriormente, revela esse mesmo efeito no qual o público potencialmente se identificará de maneira mais fácil. O princípio que estrutura a peça de Miller é o da analogia entre a situação do protagonista no enredo original de 'An Enemy' de Ibsen, e a de todos os que foram citados judicialmente sob a suspeita de subversão e tiveram de depor perante o Comitê de Atividades Antiamericanas do Senado, presidido por Joseph McCarthy.

Szondi observa em Teoria do Drama Moderno que a peça de Ibsen representa uma das mais claras tentativas de preservação da estrutura do drama, resultando em um procedimento que ele chama de "salvamento do drama". Szondi assinala como tentativa de salvamento do drama moderno o teatro naturalista, que sobre as mesmas bases do drama tradicional, buscou a preservação do gênero ${ }^{318}$. Raymond Williams, por sua vez, em Tragédia Moderna, comenta que 'An Enemy' tem as características de uma tragédia liberal, ou seja, apresenta-se como uma peça em que o protagonista é derrotado precisamente por sua maior aspiração:

No centro da tragédia liberal há uma situação isolada: um homem no ponto culminante de seus poderes e no limite de suas forças, a um só tempo aspirando e sendo derrotado, liberando energias e sendo por elas mesmas destruído. A estrutura é liberal na ênfase sobre a individualidade que se

\footnotetext{
${ }^{317}$ MILLER, Arthur. An Enemy of the People. Op.cit., p.12. [O original tem uma tendência a entrar em transições entre as cenas que são elas próprias desinteressantes, e apesar de tão pouco quanto possível da construção original ter sido alterada e a peça está exatamente como era, cena por cena, eu fiz cada ato parecer de um pedaço, ao invés de cenas separadas. E a minha razão para fazer isso é simplesmente que a tradição do teatro de Ibsen permitia a separação de cenas no estilo das óperas, enquanto a nossa exige que o público nunca esteja consciente de que uma "cena" aconteceu absolutamente.]

${ }^{318} \mathrm{O}$ drama, como bem sabemos, coloca em foco o percurso de um indivíduo dotado de livre arbítrio, e suas ações e escolhas o colocam em confronto com um antagonista, gerando assim um conflito, um clímax e depois um desenlace.
} 
excede, e trágica no reconhecimento final da derrota ou dos limites que se impõem à vida. ${ }^{319}$

O aspecto trágico da peça se apresenta justamente no reconhecimento da derrota. Como esta tragédia se caracteriza na estrutura? Por meio da ênfase na individualidade que é, na verdade, uma individualidade destruída, inviabilizada, confrontada com seus próprios limites. Esses limites, no caso do contexto norte-americano para o qual Miller volta sua atenção, situam-se no âmbito do poder estatal, ou seja, do macarthismo, e é essa a matéria prima dramatúrgica que Miller teve em mãos para escrever 'An Enemy', após o pedido do casal March e do diretor Bobby Lewis (já mencionados anteriormente). Assim sendo, quando Miller lança mão da matéria prima ibseniana, toma lbsen como referência importante no sentido de ressaltar a dimensão social (e portanto pública) dos erros e desmandos de âmbito individual (privado). Desta forma Miller reativa a matéria prima da dramaturgia ibseniana, mas o faz com uma série de transformações que ora se aproximam e ora se afastam dela ${ }^{320}$.

\section{A ESTRUTURAÇÃO FORMAL DE AN ENEMY OF THE PEOPLE}

\subsection{ENREDO}

Ibsen, utilizando-se da fórmula de peça bem feita, escreve sua peça com cinco atos, sendo que Miller os reduz a três. Tal redução em nada afeta a estrutura, pois segundo Freytag ${ }^{321}$, a questão do número de atos está mais ligada à questão da troca de cenários e figurinos do que à estrutura propriamente dita. O que se mantém, e isso verificamos na versão de Miller de An Enemy, é que o primeiro e último atos são respectivamente introdução e

\footnotetext{
${ }^{319}$ WILLIAMS, Raymond. Tragédia Moderna, op.cit., p. 119.

${ }^{320}$ Mesmo não sendo 'An Enemy of the People' de Ibsen nosso objeto de estudo, nos reportaremos a ela quando necessário para ressaltar aspectos significativos.

${ }^{321}$ FREYTAG, Gustav. Das Technik des Dramas, 1863 - A Técnica do Drama (1863).
} 
desfecho e o ato central foca no desenvolvimento ${ }^{322}$. A peça apresenta uma linha ascensional de tensão, regra de ouro da peça bem feita, como nos lembra Wayne ${ }^{323}$ e em cada uma de suas partes vemos como uma ação está ligada à seguinte e tudo se encaixa por meio da relação de causa e efeito. É preciso lembrar já de antemão que temáticas ligadas a preocupações sociais foram sendo historicamente incorporadas à forma de peça bem feita e se desvinculando do caráter inferior que lhe era atribuído comumente pela maioria dos críticos. Shaw, que também fez uso da peça bem-feita em $O$ Homem e as Armas (1894), nos lembra que o uso da estrutura da peça bem feita não é por si só inferior, embora se torne inferior se não vier acompanhada de discussão que propicie uma argumentação sobre a moral vigente. Casa de Bonecas (1879) de Ibsen, por exemplo, é uma peça que quebra a estrutura da peça bem feita utilizando-se do naturalismo ao inserir a argumentação. É justamente a argumentação que substitui o mero desfecho da peça bem feita, e dá expressão formal e conteudística diversa daquela comumente atrelada à dramática tradicional. Vejamos, então, o que Miller fez com esta estrutura "traduzindo-a" para o contexto americano.

O primeiro ato mapeará as personagens do drama e introduzirá o conflito. Ao subir o pano temos um ambiente familiar aparentemente tranquilo (típico das peças de lbsen) e que também encontramos em All My Sons. A cena se inicia na casa do Dr. Stockmann e o que se seguem são diálogos amistosos que demonstram, pelo ambiente e atitudes hospitaleiros dos anfitriões (Thomas e Catherine Stockmann), que a relação entre esses anfitriões e os amigos da imprensa "liberal" é bastante informal.

A conversa que aparentemente parece não ter impacto algum começa a tomar outros rumos com a chegada de Peter Stockmann, o prefeito. Sua entrada em cena faz com que o enredo que se desenvolverá mais adiante já comece a ganhar forma mais concreta, e faz com que já tenhamos pistas sobre aquilo em que se apoia o presente. Peter Stockmann, que chega para ver o

\footnotetext{
${ }^{322}$ Freytag menciona inclusive que peças de um ato podem ter estrutura de 'peça bem feita' desde que a ação dramática se mantenha crescente e haja encadeamento lógico de ações.

${ }^{323}$ WAYNE, S. Turner. http://www.wayneturney.20m.com/scribe.htm . - Consultado em 22/03/2012.
} 
irmão, tem uma atitude bastante condescendente com relação ao jornal em que Hovstad trabalha e diz admirar o espírito de tolerância da cidade e deixa explícito, desde o começo da peça, que o que os une é Kirsten Springs. Ficamos sabendo que a tolerância e aparente amistosidade são marcadas por uma relação de empreendimento, de dinheiro:

PETER STOCKMANN: I happen to admire the spirit of toleration in our town. It's magnificent. Just don't forget that we have it because we all believe in the same thing: it brings us together. (p.21)

PETER STOCKMANN: (...) They (Kirsten Springs) have changed the soul of this town. (p.21) ${ }^{325}$

Miller busca inclusive trazer esta noção mais próxima à realidade americana citando um balneário existente no Sul da California, em Carlsbad ${ }^{326}$, podendo proporcionar ao público maior identificação com um elemento que pode Ihes soar familiar:

PETER STOCKMANN: (...) Give us a really good summer, and sick people will be coming here in carloads. The springs will turn into a regular fad, a new Carlsbad. (p.21) ${ }^{327}$

A promessa de felicidade e bem-estar já é mostrada no início da peça, tendo ligação com uma atividade de comércio que promete rentabilidade à cidade e a seus cidadãos. Em momento algum se fala na adoção de uma política social para melhorar a qualidade de vida dos moradores da cidade. A

\footnotetext{
${ }^{324}$ MILLER, Arthur. An Enemy of the People. op.cit., p.21. [PETER STOCKMANN: Acontece que eu admiro o espírito de tolerância em nossa cidade. É magnífico. Só não se esqueça que nós temos isso, porque todos nós acreditamos na mesma coisa: isso é o que nos une.]

325 [PETER STOCKMANN: Kirsten Springs mudou a alma de nossa cidade.]

${ }^{326}$ Segundo a enciclopédia online Answers.com, Carlsbad é "A city of southern California on the Pacific Ocean north-northwest of San Diego. It is a health resort and manufacturing center. Population: 90.800." Fonte: http://www.answers.com/topic/carlsbad-california\#ixzz1qqQCVZ28 - Consultado em 27/03/2012. [Uma cidade do Sul da Califórnia ao norte-nordeste do Oceano Pacífico de San Diego. É um balneário e centro de produção.]

${ }^{327}$ MILLER, Arthur. An Enemy of the People. op.cit., p.21. [PETER STOCKMANN: (...) dê-nos um bom verão, e pessoas doentes estarão vindo aqui em carros cheios. O balneário vai se transformar em uma novidade regular, um novo Carlsbad.]
} 
noção do dinheiro enquanto determinante do bem-estar e do motor que impulsiona os sonhos é repetida um pouco adiante quando Mrs.Stockmann (Catherine) fala sobre a paixão de seu marido pelo balneário e as novas ideias que tem a respeito :

MRS.STOCKMANN: Tom is always full of ideas about the springs; every day he $-(\text { p.22) })^{328}$

PETER STOCKMANN: Well, he ought to be, he gets his salary from the springs, my dear. (p.22) $)^{329}$

O enredo, assim como em All My Sons, começa a ganhar tensão pelo embate entre personagens. Peter faz uma crítica severa dizendo que um homem de ideias não é suficiente para por um serviço em prática, pois este trabalho demanda um outro tipo de homem. Este embate entre personagens (que ajuda a construir e fazer avançar o enredo) revela algo mais profundo no que diz respeito à adaptação. $O$ aspecto abaixo, que se distancia de Ibsen, reflete uma essência mais americanizada. A posição arrogante e condescendente de Peter se mantém até a chegada de Dr. Stockmann que entra e oferece bebida ao irmão, que the responde:

PETER STOCKMANN: No, thanks, I don't go in for drinking parties (versão de Miller, p.24) ${ }^{330}$.

No original do norueguês, contudo, temos uma outra resposta cuja essência nos revela algo importante com relação à adaptação que Miller resolveu fazer:

PETER STOCKMANN: Thanks, I never care about an evening's drinking (versão de lbsen, p.5) ${ }^{33 !}$.

\footnotetext{
${ }^{328}$ [MRS. STOCKMANN: Tom está sempre cheio de ideias sobre o balneário; todo dia ele -]

329 [PETER STOCKMANN: Bom, ele tem que estar, ele ganha o salário dele através do balneário, minha querida.]

${ }^{330}$ [PETER STOCKMANN: Não, obrigado, eu nunca entro em festas de bebedeiras.]

331 IBSEN, Henrik. An Enemy of the People, op.cit., p.5. [PETER STOCKMANN: Obrigado. Eu não gosto de beber à noite.]
} 
Em Ibsen, Peter Stockmann rejeita o convite para beber, pois não aprecia tomar bebidas à noite, daí o uso da palavra "care". Já em Miller, Peter tem uma atitude mais puritana, própria do norte-americano na posição de figura pública, e diz que não vai a "noites de bebedeiras". O "não ir" a tais festas indica que ele se mostra como um homem cujos hábitos e padrões morais não podem ser influenciados por tais festas.

A questão central da peça começa a ser delineada quando o $\mathrm{Dr}$. Stockmann diz ao irmão que suspeita que a condição das águas do balneário possa estar apresentando condições anormais. O médico, que ainda não possui prova científica que comprove sua hipótese, prefere não opinar. Peter mostra, uma vez mais, seu conflito com o irmão mostrando primeiramente sua preocupação com algo público e em seguida revela que sua preocupação tem motivação pessoal:

PETER STOCKMANN: (...) Kirsten Springs must be treated in a businesslike manner, through the proper channels, and dealt with by the legally constituted authorities. I can't allow anything done behind my back in a roundabout way.

PETER STOCKMANN: You have an ingrained tendency to go your own way,

Thomas, and simply can't go on in a well-organized society. The individual really must subordinate himself to the over-all, or - groping for words, he points to himself - to the authorities who are in charge of the general welfare. $($ p.27) 333

Peter confia que as autoridades possam regular o funcionamento da sociedade e garantir o bem-estar de seus cidadãos. Quando Peter sai de cena,

\footnotetext{
${ }^{332}$ MILLER, Arthur. An Enemy of the People, op.cit. [PETER STOCKMANN: (...) Kirsten Springs precisa ser tratado de maneira profissional através dos canais apropriados e lidado pelas autoridades legalmente constituídas. Eu não posso permitir que nada seja feito pelas minhas costas de maneira indireta.]

${ }^{333}$ [PETER STOCKMANN: Você tem uma tendência arraigada de seguir seu próprio caminho, Thomas, e simplesmente não pode continuar em uma sociedade bem organizada. O indivíduo realmente deve subordinar-se ao geral, ou - tentando encontrar palavras, ele aponta para si mesmo - às autoridades que são responsáveis pelo bem-estar geral.]
} 
Stockmann faz uma crítica ao irmão que em Ibsen e Miller adquire diferenças significativas:

DR. STOCKMANN: He can't expect me to give him an accounting of every move I make, every thought I think, until I am ready to do it. (versão de Miller, p.27) 334

DR. STOCKMANN: (...) And anyhow, he can't oblige me to make my report before the proper time. (versão de Ibsen, p.8) ${ }^{335}$

A alteração feita por Miller expressa a dinâmica da perseguição macarthista, colocada em termos claros. Mais do que saber o que a pessoa fazia, o macarthismo rastreava diversas e singulares atividades feitas no passado pelos subversivos. Cada passo, cada ação e comportamento eram vigiados cautelosamente. Peter Stockmann é claramente o produto de seu trabalho, deixando sua individualidade em segundo plano, tornando-se o que a sociedade fez dele: prefeito.

A cena transcorre de maneira aparentemente trivial (novamente como em All My Sons) em que Mrs. Stockmann permanece bastante obediente e fazendo o papel que a mulher desse período histórico e dessa extração social normalmente fazia (servir comida, preocupar-se com afazeres domésticos etc). Conhecemos o Capitão Horster, Hovstad e Petra (filha de Stockmann). Petra entra em cena com uma carta que pegara na caixa de correspondência e a entrega ao pai. É a carta o elemento revelador que plantará sementes de um conflito que será colhido mais à frente, cuja resistência já começa a ser suposta pelo comportamento de Peter até agora. Stockmann expõe:

DR. STOCKMANN: (...) the whole Health Institute, is a pesthole! (p.34) $)^{336}$

DR. STOCKMANN: You know that filth up in Windmill Valley? That stuff that has such a stinking smell? It comes down from the tannery up there, and the

\footnotetext{
${ }^{334}$ [DR. STOCKMANN: Ele não pode esperar que eu lhe dê um relatório de cada movimento que eu faço, cada pensamento que eu tenho, até que eu esteja pronto para fazê-lo.]

${ }^{335}$ IBSEN, Henrik. An Enemy of the People. op.cit. [DR. STOCKMANN: (...) E de qualquer forma, ele não pode me obrigar a fazer meu relatório antes do tempo apropriado.]

${ }^{336}$ [DR. STOCKMANN: (...) todo o Instituto de Saúde é um antro de pragas!]
} 
same damn poisonous mess comes right out into the blessed, miraculous water we're supposed to cure people with! (p.34-35) 337

DR. STOCKMANN: (...) it proves the existence of infectious organic matter in the water. $(p .35)^{338}$

DR. STOCKMANN: (...) When they started the damned thing I told them not to build it down there! But who am I, a mere scientist, to tell politicians where to build a health institute! (...). (p.36)

Na última fala de Stockmann fica claro que provar pode não adiantar. A prova científica não é o bastante contra o poder institucionalizado, ao menos que este último tenha interesse. Isto, aliás, já havia sido confirmado quando Stockmann fez sua objeção à construção do encanamento no local previsto.

A segunda cena do mesmo ato (o segundo ato de lbsen) acontece na manhã seguinte e revelará de forma cabal a natureza das personagens. Kiil, sogro de Stockmann, o visita e aproveita a oportunidade para utilizar a questão das águas para resolver desavenças antigas:

KIIL: (...) your good brother ordered them to bounce me out of the council, so they chased me out like a dog! Make jackasses out of all of them, Stockmann. $(p .42)^{340}$

Nesta passagem fica evidente sua preocupação com picuinhas pessoais e a questão coletiva fica obscurecida. Kiil até oferece uma recompensa a ser doada à caridade caso o prefeito e sua trupe "mordam a isca". Este mecanismo da recompensa foi bastante divulgado no período do macarthismo através do incentivo ao patriotismo e suas recompensas, como ascensão social e plano de carreira. Kiil sai de cena e vemos Hovstad que se posiciona de modo a apoiar o

\footnotetext{
${ }^{337}$ [DR. STOCKMANN: Sabe aquela sujeira em Windmill Valley? Aquela coisa que tem um cheiro tão fedorento? Ele desce do curtume lá em cima, e a mesma maldita sujeira venenosa vem direto para a água abençoada, milagrosa com a qual deveríamos curar as pessoas!]

${ }^{338}$ [DR. STOCKMANN: (...) isso prova a existência de material orgânico infeccioso na água.]

339 [DR.STOCKMANN: Quando eles começaram com a maldita coisa eu disse a eles para não construir lá embaixo! Mas quem sou eu, um mero cientista, para dizer aos políticos onde construir um instituto de saúde! (...)]

${ }^{340}$ [KIIL: (...) O seu bom irmão pediu que eles me tirassem do conselho, então eles me perseguiram como a um cão! Faça-os todos de idiota, Stockmann.]
} 
doutor e a colocar a culpa nas autoridades. O delineamento da personagem marca o primeiro ato da peça com o apoio de Hovstad, e expõe a racionalidade envolvida em tal posicionamento:

HOVSTAD: Doctor, I think it comes from an entire different dump. (p.44) ${ }^{341}$ HOVSTAD, with growing zeal: The same dump that is poisoning and polluting our whole social life in this town. (p.44) $)^{342}$

HOVSTAD: Everything that matters in this town has fallen into the hands of a few bureaucrats. $(p .44)^{343}$

HOVSTAD: They're all rich, all with old reputable names, and they've got everything in the palm of their hands. $(p .44)^{344}$

HOVSTAD: (...) I know in my bones what the underdog needs - he's got to have a say in the government of society. That's what brings out ability, intelligence, and self-respect in people. (p.45) ${ }^{345}$

HOVSTAD: I think a newspaperman who turns down any chance to give the underdog a lift is taking on a responsibility that I don't want. I know perfectly well that in fancy circles they call it agitation, and they can call it anything they like if it makes them happy, but I have my own conscience $-(p .46)^{346}$

Esta passagem é de suma importância para a peça, pois ela expõe tanto a percepção da realidade por parte de Hovstad como uma análise aprofundada dela. Isto posteriormente será invertido quando os interesses pessoais se sobrepuserem ao bem comum. Aslaksen mostra-se interessado na "campanha por uma água melhor" a ser promovida pelo Dr. Stockmann e expõe sua disposição em ajudar:

\footnotetext{
${ }^{341}$ [HOVSTAD: Doutor, eu acho que vem de um despejo diferente.]

342 [HOVSTAD: com crescente fervor: O mesmo despejo que está envenenando e poluindo toda a nossa vida social nesta cidade.]

343 [HOVSTAD: Tudo o que importa nesta cidade caiu nas mãos de uns poucos burocratas.]

344 [HOVSTAD: Eles são todos ricos, todos com nomes respeitáveis e antigos, e eles têm tudo na palma de suas mãos.]

345 [HOVSTAD: (...) eu sei ao certo o que o oprimido precisa - ele tem de ter uma palavra a dizer no governo da sociedade. Isso é o que traz à tona a habilidade, a inteligência e o auto-respeito nas pessoas.] 346 [HOVSTAD: Eu acho que um jornalista que rejeita qualquer chance de dar ao oprimido uma elevação está assumindo uma responsabilidade que eu não quero. Eu sei perfeitamente bem que em círculos chiques eles chamam isso de agitação, e eles podem chamar do que quiserem, se isso os faz felizes, mas eu tenho minha própria consciência.]
} 
ASLAKSEN: (...) I hear that you intend to campaign for a better water system? $(\text { p.46) })^{347}$

ASLAKSEN: I just wanted to call and tell you that we're behind you a hundred per cent. (p.46)

ASLAKSEN: We can be important, Doctor. When the little businessman wants to push something through, he turns out to be the majority, you know, and it's always good to have the majority on your side. $(p .47)^{349}$

Aslaksen continua mostrando seu apoio a Stockmann, mas, diz ser moderado e diz que a verdade não pode ser negada por ninguém. Aslaksen fala, então, uma frase central para a peça:

ASLAKSEN: You have the solid majority on your side (...). (p.48) 350

Esta ideia enganosa de uma "maioria sólida" se refletia no contexto do macarthismo no qual as pessoas que aderiam à posição da maioria não o faziam movidas por um ideal que compartilhavam entre si, mas sim pela segurança que Ihes dava a adesão a uma posição forte, dominante. Esta frase emblemática expressa uma das maiores críticas de lbsen (e Miller) à tirania da maioria que, em grande número, exerce um poder de pressão bastante forte. É preciso lembrar que a maioria é sempre, historicamente, controlada/governada/guiada por uma minoria. Mesmo aquilo que se coloca como democracia é um termo incompleto (ou impreciso) que demonstra a falta de outro termo que o acompanhe, como: racial, sexual, religiosa, corporativa etc. Stockmann parece perceber isto ao criticar a minoria (aqueles que estão no poder) e sentirá na pele os efeitos de manipulação desta mesma minoria na maioria "sólida". Como tentativa de manipular Stockmann, Peter tenta dissuadir o doutor, dizendo que a "tese" das águas poluídas usa termos muito fortes e

\footnotetext{
${ }^{347}$ [ASLAKSEN: Eu ouvi que você pretende fazer uma campanha para um sistema de água melhor.] 348 [ASLAKSEN: Eu só queria denominar e te dizer que nós estamos apoiando você cem por cento.]

349 [ASLAKSEN: Nós podemos ser importantes, Doutor. Quando o pequeno empresário quer forçar a aceitação, ele se torna a maioria, sabe, e é sempre bom ter a maioria ao seu lado.]

${ }^{350}$ [ASLAKSEN: Você tem a maioria sólida ao seu lado.]
} 
possui motivação subjetiva de destruição da autoridade. Peter conclui categoricamente:

PETER STOCKMANN: Your report has not convinced me that the conditions are as dangerous as you try to make them. (p.53)

PETER STOCKMANN: I think you're exaggerating. A capable physician ought to know what precautions to take. (p.53)

PETER STOCKMANN: I said I'm not convinced that there is any actual danger.

$(p .53)^{353}$

O Dr. Stockmann explicita erros e desmandos do passado deixando claro que Peter e sua má administração insistiram que o encanamento fosse construído no lugar em que fora. Peter avisa que não será possível sustentar a "tese" (verdadeira) de que as águas estão poluídas e diz que impedirá que qualquer ideia subversiva penetre o corpo político e administrativo da cidade (assim como no macarthismo muitos cumpriam este mesmo dever). Peter fica indignado e pergunta se as pessoas do jornal já sabem. Dr. Stockmann dá uma resposta que, em Miller, assume um outro significado diferente do de Ibsen. Vejamos:

DR. STOCKMANN: Exactly. The liberal, free, and independent press will stand up and do its duty. (versão de Miller, p.54) ${ }^{354}$

DR. STOCKMANN: Yes, they know. The liberal-minded independent press is going to see that you do your duty. (versão de Ibsen, p.27)

\footnotetext{
${ }^{351}$ [PETER STOCKMANN: O seu relatório não me convenceu de que as condições são tão perigosas como você as tenta colocar.]

${ }^{352}$ [PETER STOCKMANN: Eu acho que você está exagerando. Um médico competente deve saber quais precauções tomar.]

353 [PETER STOCKMANN: Eu disse que não estou convencido de que há qualquer perigo real.]

354 [DR. STOCKMANN: Exatamente. A imprensa liberal, livre e independente irá levantar-se e cumprir seu dever.]

${ }^{355}$ IBSEN, Henrik. An Enemy of the People. op.cit. [DR. STOCKMANN: Sim, eles sabem. A imprensa de mentalidade liberal e independente irá ver se você vai fazer o seu dever.]
} 
O Dr. Stockmann de lbsen diz que a imprensa liberal e independente fará que Peter faça seu dever. Já o de Miller diz que a imprensa liberal, livre e independente fará seu dever, não o de Peter. A retórica norte-americana da liberdade, presente em quase todos os setores da vida daquele povo, comumente parte do pressuposto de que a imprensa é livre. O Dr. Stockmann (e Miller) transferem o dever/responsabilidade para o jornal, e não para 0 prefeito. Isto é interessante, pois, no macarthismo esperar que uma autoridade cumprisse seu dever era bastante complicado, visto que as autoridades estavam todas submetidas à ideologia vigente da qual eram agentes. A imprensa, contudo, teria o potencial de exercer sua obrigação em passar os fatos sem a tendenciosidade da condenação ao antiamericanismo. Após alguns embates entre os irmãos, Peter declara que o público não precisa de ideias novas, pois este é muito melhor com ideias velhas. Conclui sua fala de um modo bastante autoritário e categórico, dizendo:

PETER STOCKMANN: (...) and now I am going to give you an order. And I warn you, you had better obey it if you value your career. (p.55) 356

DR. STOCKMANN: What kind of an order? $(p .55)^{357}$ PETER STOCKMANN: You are going to deny these rumors officially. (p.55) $)^{358}$

Temos aqui um dos maiores dilemas que aparece em praticamente todas as peças de Arhur Miller: a defesa do nome e da honra. Este trecho de 'valorizar a carreira' não está no original e reflete a situação do desemprego em massa, devido ao blacklisting dos tempos macarthistas. A convicção do Dr. Stockmann, ao contrário do que pensa Peter, vem justamente da condição da água, como ele mesmo afirma. Mesmo assim o prefeito o questiona:

PETER STOCKMANN: What are you talking about convictions? You're an official, you keep your convictions to yourself! (p.56) ${ }^{359}$

\footnotetext{
356 [PETER STOCKMANN: (...) e agora eu vou te dar uma ordem. E eu estou te avisando, é melhor você obedecer se você preza pela sua carreira.]

${ }^{357}$ [DR. STOCKMANN: Que tipo de ordem?]

358 [PETER STOCKMANN: Você vai negar esses rumores oficialmente.]

359 [PETER STOCKMANN: O que você está falando sobre convicções? Você é um oficial, você mantém as suas convicções para si mesmo.]
} 
DR. STOCKMANN: To myself? $(p .56)^{360}$

PETER STOCKMANN: As an official, I said. God knows, as a private person that's something else, but as a subordinate employee of the Institute, you have no right to express any convictions or personal opinions about anything connected with policy. (p.56)

A conversa é reveladora, pois mostra a maneira de Peter em conceber o papel do trabalho e de seu trabalhador: um executor de tarefas cego e leal cuja obrigação e direito é não ter opinião. Stockmann tenta convencê-lo que não se trata de uma questão de opinião e que o fato não é de ordem subjetiva, mas sim objetiva:

DR. STOCKMANN: That source is poisoned, man. We are getting fat by peddling filth and corruption to innocent people! (p.58) $)^{362}$

Ao ousar fazer esta crítica, Peter declara que um homem que insinua críticas fortes à sua forma de governar deve ser nada além de um traidor à sociedade. O maniqueísmo se apresenta aqui como regra para a base do pensamento. Esta mentalidade é parte integrante da maioria das culturas e civilizações visto que é uma forma mais simples (e portanto mais fácil) de se pensar. Catherine, em nome da família e de si mesma, tenta preservar seu marido de uma possível retaliação. E justamente nesta passagem fica claro que Catherine não é tão ingênua quanto supostamente demonstrava ser:

MRS. STOCKMANN: Please, think! He's got all the power on his side. $(p .59)^{363}$

DR. STOCKMANN: Yes, but I have truth on mine. (p.59) $)^{364}$ MRS. STOCKMANN: Without power, what good is the truth? $(p .59)^{365}$

\footnotetext{
${ }^{360}$ [DR. STOCKMANN: Para mim mesmo?

361 [PETER STOCKMANN: Enquanto um oficial, eu disse. Deus sabe, enquanto uma pessoa individual isto é outra coisa, mas enquanto um empregado subordinado ao instituto, você não tem direito de expressar nenhuma convicção ou opinião pessoais sobre qualquer coisa ligada à política.]

${ }^{362}$ [DR. STOCKMANN: Aquela fonte está envenenada, cara. Nós estamos crescendo ao entrarmos em sujeira e corrupção às custas de gente inocente.]

363 [MRS. STOCKMANN: Por favor, pense! Ele tem todo o poder ao seu lado.]

364 [DR. STOCKMANN: Sim, mas eu tenho a verdade ao meu.]
} 
Mrs. Stockmann parece perceber a dinâmica sobre a qual está apoiada a sociedade. O poder é, definitivamente, uma arma poderosa, como pudemos constatar durante o macarthismo e ignorá-lo é entregar-se ingenuamente ao fracasso. Muitos foram aqueles que se uniram e colaboraram com o poder, pois, percebendo sua força, viam nele uma oportunidade de se isentar de acusações e ainda por cima de se beneficiar com carreirismo, o elogio público etc. Christopher Bigsby menciona que:

McCarthy invited the individual to deny any responsibility towards others, to refuse the moral logic that connected confession with betrayal, to seek safety in privatism, a disengagement from the communal. Myth became dogma, denial piety, prejudice conviction. Words reversed their meaning so that 'loyalty' indicated a willingness to betray, 'idealism' complicity in conspiracy. 'Americanism' intoleance and denial of freedom. ${ }^{366}$

O poder instituído contava com a inversão de valores contida no incentivo do governo à filiação de todos para que colaborassem. Tal impulso, que destituía as pessoas de sua dignidade na busca de salvação pessoal, somente acentuou o sentimento de intolerância que ganhava a partir de então legitimidade para ser exercido ${ }^{367}$. Ao fazer perguntas sobre o futuro dos filhos e o que eles deveriam enfrentar, Stockmann questiona verdades mais profundas:

\footnotetext{
${ }^{365}$ [MRS. STOCKMANN: Sem poder, de que serve a verdade?]

${ }^{366}$ BIGSBY, Christopher. A moral imperative. In: BIGSBY, C.W.E., Modern American Drama, 19451990. op. cit., p.81-82. [McCarthy convidava o indivíduo a negar qualquer responsabilidade perante os outros, a recusar a lógica moral que ligava confissão à traição, a buscar salvação no individualismo, uma separação da comunidade. $\mathrm{O}$ mito se tornou dogma, a negação, uma piedade e o preconceito, uma convicção. As palavras inverteram seu sentido de modo que a 'lealdade' indicava uma disposição para trair, 'idealismo', cumplicidade com a conspiração. 'Americanismo', intolerância e negação da liberdade.]

${ }^{367}$ Tal sentimento ganhou força oficial novamente com o 'Ato Patriótico' promovido durante o governo de George W. Bush, em 2003. Paradoxalmente sustentado por um jingoísmo presente na retórica da liberdade americana desde os tempos do 'arsenal da democracia' de Roosevelt (que já mencionamos), o ato patriótico buscava legitimar atos de desumanidade. Buscando "unir" o povo americano em torno do objetivo de expurgar o inimigo interno, o ato promovia e premiava o denuncismo daqueles que eram suspeitos de ameaçar o bem-estar comum. A medida só aumentou a desconfiança e histeria que encontrava na xenofobia uma oportunidade de exercer "cidadania". O filme Crossing Over, (Território Restrito, em português), dirigido por Wayne Kramer em 2009, ilustra brilhantemente tal ponto. O enredo explora a questão da imigração nos Estados Unidos mostrando como o ato patriótico promoveu a destruição da dignidade de muitas pessoas convencendo-as de que tal tarefa (a de denunciar pessoas) garantiria a manutenção dos interesses de todos.
} 
DR. STOCKMANN: (...) You want me to be the miserable animal who'd crawl up the boots of that damn gang? Will you be happy if I can't face myself the rest

of my life? ${ }^{368}$

MRS. STOCKMANN: Tom, Tom, there's so much injustice in the world! You've simply got to learn to live with it. If you go on this way, God help us, we'll have no money again. (p.60) ${ }^{369}$

A peça mostra que a preocupação, mesmo que individual, deve ser com o caráter, não com a reputação e imagem perante os outros. A fala acima, de Stockmann, quando este diz que não conseguiria encarar a si mesmo pelo resto da vida, expressa escancaradamente a posição de Miller durante o período da histeria macarthista. Quando escreveu The Crucible, Miller disse o seguinte:

(...) It is examining the questions I was absorbed with before - the conflict between a man's raw deeds and his conception of himself; the questions of whether conscience is in fact an organic part of the human being, and what happens when it is handed over not merely to the state or the mores of the time, but to one's friend or wife. ${ }^{370}$

Miller insere um diálogo inexistente na versão original de lbsen que merece ser comentado. No original os filhos (Ejlif e Morten) aparecem e o Dr. Stockmann os vê entrar em cena, mas vai para seu escritório dizendo ter o direito de olhá-los de frente quando forem adultos. Petra elogia a afirmação do pai, que admira e considera brilhante. Em Miller, contudo, temos:

\footnotetext{
368 [DR. STOCKMANN: (...) Você quer que eu seja um animal miserável que se rastejaria aos pés dessa quadrilha maldita? Você ficará feliz se eu não conseguir me encarar pelo resto da vida?]

369 [MRS. STOCKMANN: Tom, Tom, há tanta injustiça no mundo! Você simplesmente tem de aprender a viver com isso. Se você continuar assim, que Deus nos ajude, nós não teremos dinheiro novamente.] ${ }^{370}$ MILLER, ARTHUR. Brewed in The Crucible. The New York Times, 09/03/1958. In: MARTIN, Robert A; CENTOLA, Steven R, op. cit, p.172-73. [É examinando as questões com as quais eu estava absorto antes - o conflito entre os atos crus de um homem e sua concepção de si mesmo, questões de se a consciência é de fato uma parte orgânica do ser humano, e o que acontece quando ela é entregue não meramente para o Estado ou aos costumes da época, mas a um amigo ou a uma esposa.]
} 
DR. STOCKMANN: (...) He looks at the boys. Well, boys, did you learn anything in school today? $(p .60)^{371}$

MORTEN, looking at them, puzzled: We learned what an insect is. $(p .60)^{372}$ DR. STOCKMANN: You don't say! (p.61) $)^{373}$

MORTEN: What happened here? Why is everybody - $(p .61)^{374}$

DR. STOCKMANN: Nothing, nothing. You know what l'm going to do, boys? From now on I'm going to teach you what a man is. [He looks at Mrs. Stockmann. She cries as curtain falls.] (p.61) 375

Enquanto o Dr. Stockmann de Miller expõe a questão (mesmo que indiretamente aos filhos), o de lbsen não o faz. Parece-nos que Miller tem certa urgência em fazer com que a mensagem seja ouvida e resolve ensinar às crianças. Podemos concluir com este diálogo que Stockmann afirma que a natureza do homem é mais importante do que a do inseto. Aliás, a Biologia e a ciência não têm muito valor, como foi constatado com o relatório encomendado por Stockmann. Em tempos de macarthismo, qualquer análise que contradissesse o que os interesses da ideologia vigente pregavam seria facilmente descartado como "antipatriótico", "comunista", "traidor", "subversivo" etc. Esta brilhante passagem acima constitui um dos pilares mais sólidos de toda a dramaturgia milleriana e coloca a questão da consciência individual que jamais deve render-se aos ditames do momento, da religião, da economia ou mesmo daquilo que a sociedade e a maioria acham justo. A Shoah provou ao mundo como a maioria pode posicionar-se a favor da matança de milhões de judeus, homossexuais, ciganos, testemunhos de Jeová, doentes mentais,

\footnotetext{
${ }^{371}$ [DR. STOCKMANN: (...) ele olha para os meninos. Bem, meninos, vocês aprenderam algo na escola hoje?]

372 [MORTEN, olhando para eles, intrigado: Nós aprendemos o que é um inseto.]

373 [DR. STOCKMANN: Não me diga!]

374 [MORTEN: O que aconteceu aqui? Por que está todo mundo - ]

375 [DR. STOCKMANN: Nada, nada. Sabem o que eu vou fazer, meninos? De agora em diante eu vou ensinar a vocês o que significa ser um homem. (Ele olha para Mrs. Stockmann. Ela chora enquanto o pano cai.)]
} 
dentre outros e como a consciência daqueles que se diziam corretos e éticos compactuou, sem resistência, com o que a humanidade viu de pior.

O segundo ato, em Miller, possui duas cenas e aumenta a tensão mais ainda ao revelar a ambiguidade das personagens e o potencial que apresentam para 'vender' suas consciências à autoridade. Na primeira temos a chegada do Dr. Stockmann ao escritório editorial para conversar com seus amigos "liberais". Billing se mostra bastante satisfeito com a descoberta de Stockmann e celebra o que para ele soa como a chegada de uma revolução ${ }^{376}$. Segue adiante criticando Aslaksen dizendo que ele, com sua conversa sobre moderação, é um covarde e pergunta o que Hovstad acha. Este último diz que imprimirá o artigo do doutor com ou sem o consentimento de seu irmão mostrando apoio incondicional ao Doutor. Neste momento, há especulação de que o poder administrativo ficará finalmente nas mãos dos Liberais. O Dr. Stockmann entra em cena pedindo que o artigo seja impresso e diz:

DR. STOCKMANN, continuing: He actually tried to blackmail me! He's got the nerve to tell me that I'm not allowed to speak my mind without his permission! Imagine the shameless effrontery! (p.65) ${ }^{377}$

DR. STOCKMANN: (...) The trouble with me was I kept giving them credit for being our kind of people, but they're dictators! They're people who'll try to hold power even if they have to poison the town to do it. $(p .65)^{378}$

Esta passagem, inexistente em Ibsen, revela mais um mecanismo comum adotado durante o macarthismo: o suborno. $\mathrm{O}$ discurso competente e sua retórica são simultaneamente denunciados. Pessoas comuns (our kind of people) são justamente aquelas que se utilizam do discurso do povo e se

\footnotetext{
${ }^{376}$ É interessante que, no original, Billing (p.33) diz: [(...) We must strike blow upon blow until the whole of this aristocracy tumbles to pieces (...)]. Já em Miller, só há a previsão de uma revolução, mas, não se fala nada sobre aristocracia. [(...) Nós precisamos dar um golpe atrás do outro até que toda esta aristocracia caia aos pedaços.]

377 [DR. STOCKMANN, continuando: Na verdade, ele tentou me chantagear! Ele tem a coragem de me dizer que eu não estou autorizado a dizer o que penso sem sua permissão! Imagina o descaramento sem vergonha!]

${ }^{378}$ [DR. STOCKMANN: (...) O problema comigo era eu continuei dando-lhes crédito por ser o nosso tipo de gente, mas eles são ditadores! São pessoas que vão tentar manter o poder, mesmo que tenham de envenenar a cidade para mantê-lo.]
} 
identificam com o mesmo. Contudo, estão no poder e ditam (dictators) o que deve ser feito sem o consenso do povo.

Aslaksen entra em cena pedindo moderação e diz concordar com o doutor. Stockmann diz que implodirá meias palavras, mentiras etc, e é apoiado por Aslaksen, contanto que haja moderação. Aslaksen no mesmo momento expressa sua preocupação dizendo que a questão deve ligar-se somente à crítica das águas, mas, não à administração da cidade:

ASLAKSEN: (...) You attack the national government, what's going to happen? Nothing. They go right on. But a town administration - they're liable to be overthrown or something! I represent the small property owners in this town$(\text { p.67) })^{379}$

Ao se pensar em autoridades e como estas podem afetar o interesse de cada um, a peça começa a mostrar os interesses pessoais se sobrepondo ao coletivo. Billing fica indignado dizendo que é só dar uma propriedade ao pequeno homem que a verdade pode ir por água abaixo. Aslaksen faz menção a um ex-trabalhador para que Billing entenda que as pessoas têm interesses particulares. Ainda com a relutância de Billing, Aslaksen coloca claramente:

ASLAKSEN: You're a politician. A politician never knows where he's going to end up. And besides you applied for a job as secretary to the Magistrate, didn't you? (p.67) ${ }^{380}$

Aqui fica evidente o obstáculo que poderá se interpor no plano de carreira de Billing, o que também constituiu uma ameaça àqueles que visavam ter uma carreira bem sucedida no período do macarthismo. Aslaksen conclui

\footnotetext{
${ }^{379}$ [ASLAKSEN: (...) Você ataca o governo nacional, o que vai acontecer? Nada. Eles seguem em frente. Mas a administração da cidade - eles são susceptíveis de serem derrubados ou algo assim! Eu represento os pequenos proprietários desta cidade -]

${ }^{380}$ [ASLAKSEN: Você é um político. Um político nunca sabe onde irá terminar. E além do mais, você se candidatou para uma vaga de secretário do magistrado, não foi?]
} 
seu raciocínio explicitando, uma vez mais, o que era visto frequentemente no período supracitado:

ASLAKSEN: (...) People change. Just remember when you call me a coward (...). $(\text { p.67) })^{381}$

Interessante esta fala, pois como já mencionado anteriormente, a relação de Miller com Elia Kazan (para o qual foi dedicado All My Sons) viria a ser abalada com a adesão deste à política do naming names. Kazan ${ }^{382}$ forneceu ao Comitê de Atividades Antiamericanas nomes de possíveis comunistas, o que viria a ser condenado por muitos intelectuais de esquerda e por cidadãos americanos que o consideraram traidor ${ }^{383}$. Em seu depoimento Kazan diz:

I've often, since then, felt on a personal level that it's a shame that I named people, although they were all known, it's not as if I were turning them over to the police; everybody knew who they were, it was obvious and clear. It was a token act to me, and expressed what I thought at the time. ${ }^{384}$

Seu ato simbólico, entretanto, pareceu ignorar o "efeito dominó" que se estabeleceria com a profusão do fanatismo anticomunista antigo. Tal efeito potencializou-se com as audiências televisionadas e com a gigantesca adesão

\footnotetext{
${ }^{381}$ [ASLAKSEN: (...) As pessoas mudam. Só se lembre disso quando me chamar de covarde (...).]

${ }^{382}$ O documentário "None Without Sin: Elia Kazan, Arthur Miller, and the Blacklist (2003)", sob direção de Michael Epstein, aborda esta questão delicada que determinou a relação dos dois e, consequentemente, mostrou que Miller não vendera sua consciência às exigências que aquele momento impunha. Um fato bastante intrigante é que o documentário não é comercializado, dificilmente é encontrado para ser assistido via internet e segundo Christopher Bigsby (em conversa comigo por email), os direitos pertencem à 'PBS-United States' que me negou o acesso dizendo que o material não poderia ser vendido ou comercializado.

${ }^{383}$ Um fato bastante marcante foi a cerimônia de premiação do Oscar de 1999, na qual Kazan recebera um prêmio honorário. Marcada por protestos, vaias e recusa de algumas pessoas na plateia em aplaudi-lo, a cerimônia fracionou a opinião do público que de um lado considerava Elia Kazan enquanto homem e de outro, enquanto artista/diretor.

${ }^{384}$ NAVASKY, Victor S. Naming names. New York, Hill and Wang, 2003, p.208. [Eu tenho frequentemente, desde então, sentido em nível pessoal que foi uma vergonha eu ter nomeado pessoas, apesar de que todos eram conhecidos, não é como se eu os tivesse entregue à polícia; todos sabiam quem eles eram, era óbvio e claro. Foi um ato simbólico para mim, e expressava o que eu pensava naquele momento.]
} 
de pessoas que, com medo de que o país perdesse sua posição de prestígio, pudessem também perder seus empregos e reputação.

Retornando a An Enemy, a ambiguidade das personagens vai sendo desmascarada progressivamente no enredo e uma cena em que Petra chega para devolver o livro a Hovstad nos chamou a atenção. O embate entre os dois é concluído com Hovstad afirmando ser um radical, mas também um "newspaperman". Hovstad assume que a concepção do jornal e do jornalista é agradar o leitor, manipulando fatos para que este fique satisfeito. Sendo assim, defende também que ideologias e convicções são manipuláveis conforme a necessidade que se impõe.

Praticamente todas as personagens de All My Sons fazem o mesmo: Chris suspeitava que o pai fosse culpado, mas preferiu não admitir isso por muito tempo; Ann, sabendo que Joe Keller era o culpado do crime e que seu pai é inocente, diz até o final da peça que não o denunciará, pois quer se casar com Chris; Jim Bayliss sabe do crime, mas age como se Keller fosse um exemplo de empresário etc.

Peter Stockmann vai conversar com os rapazes da imprensa e explicita que haverá taxação para a reforma e apresenta um pequeno relatório com os "verdadeiros" fatos. O prefeito recebe apoio dos rapazes e a chegada do Dr.Stockmann no mesmo momento coloca o enredo em um pico de tensão no qual as personagens se confrontarão e ameaças serão feitas. O Dr. Stockmann se convence de que há algo errado ao ver a bengala e o chapéu de seu irmão e infere que o mesmo estivera ali. Peter aparece e ao pedi-lo de volta, sob o pretexto de ser insígnia oficial, Peter recebe como resposta:

DR. STOCKMANN: I just wanted you to realize, Peter - he takes off the hat and looks at it - that anyone may wear this hat in a democracy, and that a free citizen is not afraid to touch it. (p.79) ${ }^{385}$

\footnotetext{
${ }^{385}$ [DR. STOCKMANN: Eu só queria que você percebesse, Peter - ele tira o chapéu e olha para ele que qualquer um pode usar esse chapeu em uma democracia, e que o cidadão livre não tem medo de tocálo.]
} 
No original, Stockmann parece mais idealista ${ }^{386}$ dizendo que as pessoas recentemente "acordadas" e com "coração-de-leão" não têm medo de um chapéu. Miller parece se apoiar em um conceito mais concreto: o de democracia (teoricamente garantida pela constituição), para justificar seus atos. Temos a impressão de que o Stockmann de Miller faz isso porque está em uma democracia e tem direito, enquanto o de Ibsen o faz por princípio. O que vimos a seguir é um bombardeio sistemático às ideias de Stockmann e na fala de Aslaksen temos um elemento importante:

ASLAKSEN: I'm not going to ruin this paper and this town. Doctor, for the sake of your family - (p.79) 387

Aqui vemos a ameaça que o macarthismo colocava quando misturava as questões públicas que se estendiam ao privado. Aslaksen não quer que o fato das águas estarem poluídas (questão de ordem pública) afete seu jornal (questão de ordem privada). Peter Stockmann pede, em vão, que Dr. Stockmann esqueça a questão. Este, contudo, diz:

DR. STOCKMANN: Your Honor, I can't forget it, and you will never forget it as long as you live. I am going to call a mass meeting, and I - (p.80)

A correlação desta fala com o conceito de "condenação à liberdade", de Jean Paul Sartre, se faz mister e o Dr. Stockmann explicita que a consciência é algo que não pode ser suprimido nem mesmo pelas proibições e censuras. Mesmo com todas as negações e indisposições por parte dos detentores do

\footnotetext{
${ }^{386}$ Miller parece ter feito Stockmann um pouco menos idealista e mais realista porque, segundo Downer (1951, p.142-143), "For the man of Miller's generation, who reached maturity during the thirties, it is not possible to see the other side of the mountain (...). In one sense, this represents the absolute standards of melodrama, the defined good versus the defined evil, the oversimplification of values. In another sense, this is a precise mirror of an aspect of American culture at mid-century". Acreditamos, contudo, que Miller transcede o maniqueísmo mostrando que o bem e o mal existem e que é preciso assumir responsabilidade perante escolhas. [Para o homem da geração de Miller, que atingiu maturidade durante os anos trinta, não é possível ver o outro lado da montanha (...). Em certo sentido isso representa o padrão absoluto do melodrama, o bem definido versus o mal definido, a super simplificação de valores. Em outro sentido, este é um espelho preciso de um aspecto da cultura americana em meados do século.] 387 [ASLAKSEN: Eu não vou arruinar este jornal e nem esta cidade. Doutor, pelo amor da sua família -.] 388 [DR.STOCKMANN: Meritíssimo, eu não posso esquecer, e você nunca vai esquecer, enquanto você viver. Vou convocar uma reunião em massa, e eu -.]
} 
poder, o Dr. Stockmann diz que sairá pelas ruas espalhando a notícia das águas poluídas e do corpo político também contaminado.

A segunda cena do segundo ato se inicia na casa do Capitão Horster em um ambiente vazio, como se estivesse inutilizado por um longo tempo. É esta cena que gerará o clímax ao "sufocar" Stockmann impedindo-o de falar a verdade. Quando a cortina levanta, o ambiente está vazio e o capitão carrega água, copos e um sino. Ouve-se uma multidão conversando do lado de fora. Em Ibsen, contudo, o ambiente está praticamente lotado com pessoas de todos os tipos, incluindo mulheres e crianças. Miller imediatamente mostra o quão rápida foi a "união" do povo que se posicionou ao lado da autoridade sem questionar ou ter evidências que comprovassem as "verdades" que Ihes eram passadas. Em Miller a cena começa com um diálogo entre o Capitão Horster e Billing. O Capitão pergunta o porquê de as pessoas não terem entrado e Billing revela sua admiração/conversão à confiança na autoridade:

BILLING: (...) I guess they're waiting for the Mayor or somebody important so they can be sure it's respectable in here. I wanted to ask you a question before it begins, Captain. Why are you lending your house for this? I never heard of you connected with anything political. $(p .82)^{389}$

Esta passagem demonstra um outro artifício inerente ao contexto do macarthismo: investigar conexões passadas que pudessem incriminar seja por apoio direto ou indireto ao comunismo. $\mathrm{O}$ fanatismo expresso pela adesão cega no início da fala mostra que o povo será guiado pela autoridade, pois ela representa o respeito. É novamente o apego ao discurso competente um dos responsáveis pela adesão à ideologia vigente ${ }^{390}$. Horster diz que viaja sempre e que já esteve em lugares em que as pessoas não podiam falar coisas que não fossem populares e diz não gostar disto. Horster parece simbolizar 0

\footnotetext{
389 [BILLING: (...) Eu acho que eles estão esperando o prefeito ou alguém importante para que eles possam ter a certeza de que é respeitável aqui. Eu queria fazer uma pergunta antes de começar, Capitão. Por que você está emprestando sua casa para isso? Eu nunca ouvi falar de você conectado com qualquer coisa política.]

${ }^{390}$ Não podemos nos esquecer, certamente, que existe o livre arbítrio e que escolhas são feitas.
} 
'Fellow Traveler ${ }^{391}$, e coincidência ou não, ele mesmo diz ser um "viajante", o que dá mais sentido ainda quando fazemos uma referência ao termo popular supracitado. Assim como os fellow travelers, Horster mostra simpatia à causa de Stockmann, sem ser partidário da ideologia vigente. As pessoas chegam para a reunião de Stockmann e, dentre elas, Petra com sua mãe. Mrs. Stockmann pergunta a Billing:

MRS. STOCKMANN: (...) Why did you print the Mayor's statement and not a word about my husband's report? Nobody's had a chance to find out what he really stands for. Why, everybody on the street there is against him already!

$(p .83)^{392}$

Aqui podemos ver o mecanismo de 'Naming Names' somado à mentalidade maniqueísta sobre a qual se apoiam a maioria das civilizações do Ocidente: ou bom ou mau, pagão ou religioso, santo ou demoníaco etc. No caso em questão, se o prefeito consegue ter sua declaração impressa e o Dr. Stockmann não, isto é supostamente um indicativo de que o que este último tem a dizer não é algo a ser levado em consideração (pelo menos por parte daqueles que detêm o poder). Se o prefeito é visto como autoridade e esta é símbolo de respeito e simpatia, a outra parte (Dr. Stockmann), portanto, deve ser vista como sua antítese. Quando Peter Stockmann entra, seguido da multidão, fala com Petra:

PETER STOCKMANN: (...) Petra, did you paint that poster? The one somebody stuck on the Town Hall. (p.84)

PETRA: If you can call it a painting, yes. $(p .84)^{394}$

\footnotetext{
391 (...) a term not widely used in the United States until the Cold War and originally used in Russia to describe writers who actively engaged in literary propaganda of the Bolsheviks but did not join the party. JACOBY, Susan. The Age of American Unreason. Vintage Books, New York: 2009, p.87. [(...) um termo não amplamente utilizado nos Estados Unidos até a Guerra Fria e originalmente usado na Rússia para descrever escritores que participavam ativamente na propaganda literária dos bolcheviques, mas não aderiam ao partido.]

392 [MRS. STOCKMANN: (...) Por que você imprimiu a declaração do prefeito e nem uma palavra sobre o relatório do meu marido? Ninguém teve a chance de descobrir o que ele defende. Ora, todo mundo na rua já está contra ele.]

393 [PETER STOCKMANN: (...) Petra, você pintou aquele cartaz? Aquele que alguém pregou na prefeitura.]

${ }^{394}$ [PETRA: Se você pode chamá-lo de uma pintura, sim.]
} 
PETER STOCKMANN: You know I could arrest you? It's against the law to deface the Town Hall. $(p .84)^{395}$

PETRA: Well, here I am. She holds out her hands for the handcuffs. $(p .84)^{396}$ MRS. STOCKMANN: If you arrest her, Peter, l'll never speak to you! (p.84) PETER STOCKMANN, laughing: Catherine, you have no sense of humor! $(\text { p. } 84)^{398}$

Tal senso de humor é expresso em forma de ameaça. Peter mostra que tem poder e que poderia prender sua sobrinha, mas não o faz, o que dá à situação um tom de "humor". Petra, contudo, não se deixa intimidar e entregase voluntariamente ao tio. O Doutor Stockmann chega, mas, é impedido de começar, pois, segundo Aslaksen, é necessário eleger um presidente. A cena apresenta alguns cidadãos que falam coisas bastante triviais, mas, um deles, que se encontra embriagado, é, na verdade, o mais sensato de todos:

DRUNK: I wanna vote! I got the right to vote! (p.85) ${ }^{399}$

É o Bêbado o único na multidão a querer exercer o direito (obrigação) democrático, enquanto os outros (que estão sóbrios) optam por não votar. Enquanto os outros estão mais preocupados em assistir ao "show" e vibram com gritos e palmas, o bêbado exige que seu direito seja validado. Um deles, o cidadão número quatro, também diz algo importante:

FOURTH CITIZEN: We know plenty of you, Stockmann. $(p .87)^{400}$

De antemão, todos já "conheciam" o histórico do Dr. Stockmann e tal sabedoria/conhecimento advinha dos discursos competentes proferidos pelas

\footnotetext{
395 [PETER STOCKMANN: Você sabe que eu poderia prendê-la? É contra a lei para desfigurar a prefeitura.]

${ }^{396}$ [PETRA: Bem, aqui estou eu. Ela estende as mãos para as algemas.]

397 [MRS. STOCKMANN: Se você a prender, Peter, eu nunca mais falarei com você.!]

398 [PETER STOCKMANN, rindo: Catherine, você não tem senso de humor!]

399 [BÊBADO: Eu quero votar! Eu tenho direito de votar!]

${ }^{400}$ [QUARTO CIDADÃO: Nós sabemos muito de você, Stockmann.]
} 
autoridades. De maneira análoga, no macarthismo todos também já "conheciam" o histórico dos acusados e as audiências nada mais eram do que cerimônias de degradação, como nos lembra Victor Navasky ${ }^{401}$. Peter Stockmann inicia e ao mesmo tempo sumariza (o que é bastante curioso) o seguinte:

PETER STOCKMANN: (...) Here's the issue: Doctor Stockmann, my brother and believe me, it is not easy to say this - has decided to destroy Kirsten Springs, our Health Institute. (p.88)

O emprego de termos fortes constituiu um pilar fundamental na retórica dos inquisidores e Peter afirma que o objetivo do Doutor é destruir Kirsten Springs, e não simplesmente reformá-la. Peter Stockmann continua a explicar o que deveria ser explicado e esclarecido pelo Doutor, e não por ele. O enredo começa a ganhar tensão com a ênfase em questões de ordem privada, com a manipulação do discurso por parte de Peter, que demoniza a motivação "privada" e "diabólica" de Dr. Stockmann:

PETER STOCKMANN: (...) He is a man, always has been, who is never happy unless he is badgering authority, ridiculing authority, destroying authority. He wants to attack the springs so he can prove that the administration blundered in the construction. $\left(\right.$ p.89) ${ }^{403}$

A questão é dirigida em termos estritamente privados como uma rebeldia que precisa ser domada antes que o caos se instale. Logo a seguir vemos a justificativa em se passar por cima de direitos democráticos, mais especificamente, o direito à livre expressão:

\footnotetext{
${ }^{401}$ NAVASKY, Victor. Naming names. op.cit.

402 [PETER STOCKMANN: (...) Aqui está o problema: Doutor Stockmann, meu irmão - e acredite em mim, não é fácil dizer isso - decidiu destruir Kirsten Springs, nosso Instituto de Saúde.]

403 [PETER STOCKMANN: (...) Ele é um homem, sempre foi, que nunca está feliz, a menos que ele esteja atormentando, ridicularizando e destruindo a autoridade. Ele quer atacar o balneário para que ele possa provar que o governo errou na construção.]
} 
PETER STOCKMANN: (...) Now there are a number of people here who seem to feel that the Doctor has a right to say anything he pleases. After all, we are a democratic country. Now, God knows, in ordinary times l'd agree a hundred per cent with anybody's right to say anything. But these are not ordinary times. Nations have crises, and so do towns. There are ruins of nations, and there are ruins of towns all over the world, and they wrecked by people who, in the guise of reform, and pleading for justice, and so on, broke down all authority and left only revolution and chaos. (p.89) ${ }^{404}$

Há algo de bastante maquiavélico nessa afirmação cujo significado vai de encontro ao famoso "Os fins justificam os meios". Aplicando esta passagem à realidade do macarthismo, fica clara a manipulação da psique americana em relação a entender que direitos democráticos devem ser restritos, e que existe a ameaça de caos e a perspectiva da revolução. Peter Stockmann prossegue com sua explanação:

PETER STOCKMANN: (...) Today we're just on the verge of becoming internationally known as a resort. I predict that within five years the income of every man in this room will be immensely greater. I predict that our schools will be bigger and better. And in time this town will be crowded with fine carriages; great homes will be built here; first-class stores will open all along Main Street. I predict that if we are not defamed and maliciously attacked we will someday be one of the richest and most beautiful resort towns in the world. (...) Now all you've got to do is ask yourselves a simple question: has any one of us the right, the "democratic right", as they like to call it, to pick at minor flaws in the springs, to exaggerate the most picayune faults? Cries of No, No! And to attempt to publish these defamations for the whole world to see? We live or die on what the outside world thinks of us. I believe there is a line that must be drawn, and if a man decides to cross that line, we the people must finally take him by the collar and declare, "You cannot say that!" (p.90) $)^{405}$

\footnotetext{
404 [PETER STOCKMANN: (...) Agora, há um número de pessoas aqui que parece sentir que o doutor tem o direito de dizer qualquer coisa que ele quiser. Afinal, somos um país democrático. Agora, só Deus sabe, em tempos normais, eu concordo cem por cento com o direito de qualquer um de dizer qualquer coisa. Mas estes não são tempos normais. As nações têm crises, e as cidades também. Há ruínas de nações, e há ruínas de cidades de todo o mundo, e elas foram destruídas por pessoas que, sob o pretexto de reforma, e implorando por justiça, e assim por diante, quebraram toda a autoridade e deixaram apenas revolução e caos.]

${ }^{405}$ [PETER STOCKMANN : (...) Hoje nós estamos apenas à beira de ficarmos conhecidos internacionalmente como um resort. Prevejo que dentro de cinco anos a renda de cada um nesta sala será imensamente maior. Eu prevejo que nossas escolas serão maiores e melhores. E com o tempo esta cidade estará repleta de carros finos, grandes casas serão construídas aqui, lojas de primeira classe vão abrir por toda Main Street. Eu prevejo que, se não formos difamados e maliciosamente atacados, nós vamos ser um dia uma das cidades mais ricas com um dos mais belos resorts do mundo. ( ... ) Agora, tudo o que vocês têm a fazer é fazer uma pergunta simples: tem qualquer um de nós o direito, o "direito democrático" , como gostam de chamá-lo, de criticar pequenas falhas no balneário, para exagerar as falhas mais insignificantes? Gritos de Não, Não! E tentar publicar essas difamações para o mundo inteiro ver? Nós vivemos ou morremos com o que o mundo externo pensa sobre nós. Eu acredito que há uma
} 
Temos aqui a fala de uma personagem cujo espírito é o do New Deal. Um entusiasmo crescente e sonhos a serem concretizados, fazem parte do plano desta sociedade que quer progredir e produzir. Não é a toa que "nós vivemos ou morremos com o que o mundo externo pensa sobre nós" fala sobre reputação. Peter inclusive invoca a retórica do americanismo, dizendo "we the people 406 ", colocando-se como um homem do povo. Contudo, este homem impõe proibições e censura. É então neste momento que Peter decide abrir o voto para proibir o Doutor de ler o relatório ao público. O trecho a seguir, extraído da peça de Miller, não aparece no original do modo como está aqui:

DR. STOCKMANN: Well, aren't you going to let me speak at all? $(p .91)^{407}$ ASLAKSEN: Doctor, we are just about to vote on that question. (p.91) 408 DR. STOCKMANN: But damn it, man, l've got a right to $-(p .91)^{409}$ PETRA, standing up: Point of order, Father! (p.91) 410 DR. STOCKMANN, picking up the cue: Yes, point of order! (p.91) 411

\footnotetext{
linha que deve ser feita, e se um homem decide cruzar esta linha, nós, o povo, devemos finalmente pegálo pelo colarinho e declarar: "Você não pode dizer isso!"]

${ }^{406} \mathrm{O}$ termo 'The People' possui uma origem interessante. No sentido de agregar a América na década de 1930, Keneth Burke cunha deliberadamente a expressão 'The People', descartando 'The Worker', por achar que o novo termo não contém a ideia de divisão de classe. Além disso, considerando que os trabalhadores em geral sofreram muito na década de 30, cunhar o termo 'The Worker' seria um fracasso e não ajudaria a alargar o alcance do termo. 'The People', desta forma, contemplaria todo e qualquer cidadão da América.

${ }^{407}$ [DR. STOCKMANN: Bem, você não vai me deixar falar definitivamente?]

${ }^{408}$ [ASLAKSEN: Doutor, nós estamos para votar sobre essa questão.]

409 [DR. STOCKMANN: Mas, que droga, cara. Eu tenho o direito de - ]

410 [PETRA, levantando-se: Ponto de ordem, Pai!]

${ }^{411}$ No original, Peter Stockmann proíbe Dr. Stockmann de ler o relatório e este aceita. O termo 'Point of Order' é usado quando em um debate as regras são quebradas e assim pode-se impedir que a pessoa que fale prossiga. O primeiro e ainda mais importante documentário sobre o macarthismo é o "Point of Order!", de Emile de Antonio, que compilou 188 horas de cobertura televisiva das audiências de 1954, presididas por Joseph McCarthy, nas quais o Exército norte-americano havia sido acusado de abrigar comunistas.
} 
Dr. Stockmann fica sem saber o que fazer e diz querer discutir a moção. O Doutor segura o relatório, mas, devido à comoção do público, com gritos e um sopro de corneta, desiste ${ }^{412}$. Stockmann ironiza os "amigos" liberais e democráticos parabenizando-os pela luta pelo direito à liberdade de expressão por tantos anos e conta que quando viveu no Norte, as pessoas eram praticamente "não-pessoas". A referência que Stockmann faz é a de que os cidadãos de lá vivem em dificuldade e ainda nem chegaram a um estágio em que precisassem de um médico. Billing diz que isto não é maneira de se referir a um povo decente e trabalhador. É justamente neste trecho que Miller faz uma mudança importante na escrita original de Ibsen. Vejamos:

BILLING: Is that the way you refer to decent hard-working people! $(p .93)^{413}$

DR. STOCKMANN: I expected that, my friend, but don't think you can fog up my brain with that magic word - the People! Not anymore! Just because there is a mass of organisms with the human shape, they do not automatically become a

People. That honor has to be earned! Nor does one automatically become a Man by having human shape, and living in a house, and feeding one's face and agreeing with one's neighbors. That name also has to be earned $(\ldots)$ $(p .93)^{41}$

A mudança feita por Miller é dupla: a implicação do que Ibsen havia escrito e a inserção da crítica ao macarthismo. Miller precisou fazer alterações no discurso de Stockmann para que não soasse fascista e não implicasse em questões biológicas de que alguns são melhores que outros por questões naturais. O Dr. Stockmann prossegue seu discurso explicitando seu relacionamento com as águas:

DR. STOCKMANN: (...) I spent months without pay or encouragement and dreamed up the whole Project of the springs. And why? Not as my brother says, so that fine carriages could crowd our streets, but so that we might cure the

\footnotetext{
${ }^{412}$ Tal histeria, que reflete de forma simbólica a do período macarthista, é em The Crucible mostrada pelas garotas que desmaiam e repetem frases em uníssono.

${ }^{413}$ [BILLING: É desta forma que você se refere às pessoas decentes e trabalhadoras!]

${ }^{414}$ [DR. STOCKMANN: Eu esperava isso, meu amigo, mas não ache que você pode embaçar o meu cérebro com essa palavra mágica - o Povo! Não mais! Só porque há uma massa de organismos com a forma humana, eles não se tornam automaticamente um Povo. Essa honra tem de ser conquistada! Tampouco alguém se torna automaticamente um homem por ter forma humana, por viver em uma casa, e por alimentar-se e concordar com os vizinhos. Esse título também tem de ser conquistado (...)]
} 
sick, so that we might meet people from all over the world and learn from them, and become broader and more civilized. In other words, more like Men, more like a People. (p.94)

A intenção de Peter Stockmann e a de Thomas ficam claramente distintas. Um tem interesses comerciais (de prosperidade material), o outro um objetivo nobre de causa social (curar os doentes). O Dr. Stockmann prossegue com sua crítica feroz à massa, que se submete aos ditames daqueles que estão no poder, explicitando uma das maiores contradições da democracia: a maioria, que é um elemento importante à democracia, assume uma aura sacra e correta, mas, nem sempre o é. Exemplos conhecidos como os de Galileu ou de Jesus ilustram este ponto em Miller, mas não em Ibsen:

DR. STOCKMANN: (...) I am a revolutionist! I am in revolt against the age-old lie that the majority is always right! (p.94) ${ }^{416}$

DR. STOCKMANN: And more! I tell you now that the majority is always wrong, in this way! (p.94) ${ }^{417}$

DR. STOCKMANN: Was the majority right when they stood by while Jesus was crucified? Silence. Was the majority right when they refused to believe that the earth moved around the sun and let Galileo be driven to his knees like a dog? It takes fifty years for the majority to be right. The majority is never right until it does right. (p.94-95) ${ }^{418}$

Ao inserir tais exemplos Miller busca demonstrar como a noção sacra da maioria não garante legitimidade e coerência às ações. Para terminar seu raciocínio, o Dr. Stockmann conta uma pequena história de um grupo de soldados indo em direção ao inimigo na certeza de estarem na estrada certa.

\footnotetext{
${ }^{415}$ [DR. STOCKMANN: (...) Eu passei meses sem salário ou encorajamento e sonhava com todo o projeto do balneário. E por quê? Não como meu irmão diz, para que carros finos pudessem lotar nossas ruas, mas para que pudéssemos curar os enfermos, para que pudéssemos conhecer pessoas de todo o mundo e aprender com eles, e tornar-nos mais amplos e mais civilizados. Em outras palavras, mais como homens, mais como um povo.]

${ }^{416}$ [DR. STOCKMANN: (...) Eu sou um revolucionário! Estou em revolta contra a mentira antiga que a maioria está sempre certa!]

${ }^{417}$ [DR. STOCKMANN: E mais! Eu digo a vocês agora que a maioria está sempre errada, desta forma.] 418 [DR. STOCKMANN: A maioria estava certa quando eles ficaram olhando enquanto Jesus era crucificado? Silêncio. A maioria estava certa quando ela se recusou a acreditar que a terra se movia em torno do sol e deixou Galileu ser conduzido de joelhos como um cão? Demora cinquenta anos para que a maioria esteja certa. A maioria nunca está certa até que faça o certo.]
} 
Um outro homem sozinho, vendo que a estrada é perigosa, não teria o direito de avisar à maioria?

DR. STOCKMANN: (...) Isn't it clear that this man must have the right to warn the majority, to argue with the majority, to fight with the majority if he believes he has the truth? Before many know something, one must know it! (p.95) ${ }^{419}$

Aqui Miller explicita, através da fala de Stockmann, que o conhecimento parte sempre de alguém, de uma pessoa. Portanto, em um sentido mais amplo, a ideia da maioria não é uma verdade absoluta, mas, a verdade de uma pessoa que passa a ser divulgada e aceita pelos que se identificam com ela. Após os argumentos de Stockmann serem rejeitados como "não-patrióticos", sua sentença é dada:

ASLAKSEN, ringing for quiet: I would like to submit the following resolution: The people assembled here tonight, decent and patriotic citizens, in defense of their town and their country, declare that Doctor Stockmann, medical officer of Kirsten Springs, is an enemy of the people and of his community. (p.97) $)^{420}$

As pessoas começam a sair aplaudindo e gritando, o que nos remete novamente ao contexto da histeria macarthista. Stockmann pergunta ao Capitão se há espaço no navio para ele e para sua família irem à América. Um dos cidadãos alerta ou ameaça (?) Stockmann mandando-o embarcar logo. Mrs. Stockmann pede para sair pela porta dos fundos, mas, Stockmann se recusa e sai com uma multidão gritando palavras e ameaças como: traidor, inimigo, "jogue-o no rio" etc.

O terceiro e último ato é aquele que dará um desfecho à peça e que conferirá à tragédia seu caráter liberal, como teoriza Raymond Williams ou que terminará com um conflito trágico cerrado, como define Albin Lesky. $\mathrm{O}$ ato se

\footnotetext{
419 [DR. STOCKMANN: (...) Não é claro que este homem deve ter o direito de avisar a maioria, para discutir com a maioria, para lutar com a maioria, se ele acredita que tem a verdade? Antes de muitos saberem alguma coisa, alguém precisa saber.]

${ }^{420}$ [ASLAKSEN, pedindo silêncio: Eu gostaria de apresentar a seguinte resolução: O povo reunido aqui hoje à noite, os cidadãos decentes e patrióticos, em defesa de sua cidade e seu país, declara que o doutor Stockmann, médico de Kirsten Springs, é um inimigo do povo e de sua comunidade .]
} 
inicia na casa de Stockmann na manhã seguinte, com a sala cheia de pedras e vidros quebrados no chão. O Dr. Stockmann está com sua esposa recolhendo os objetos e vê uma pedra rolando embaixo da cadeira:

DR. STOCKMANN, looking out: A little boy. Look at him run! He picks up the stone. How fast the poison spreads - even to the children. (p.99) ${ }^{421}$

Este início em que Stockmann vê o garoto não se encontra no original, mas, Miller o coloca para ilustrar como a histeria 'varre' subitamente toda uma sociedade e tem um grande potencial de fixar a mentalidade nas gerações mais novas. Miller, com sua convicção de que não há inocentes, coloca a infância como passível de ser determinada pela ideologia presente e, mais importantemente, de ser responsável por tomar decisões ${ }^{422}$. Em All My Sons, o garoto Bert também presentifica a realidade da fácil doutrinação da criança que, longe de ser inocente, também está apta a fazer escolhas, sejam elas conscientes ou não. No momento em que Mrs. Stockmann revela que o vidraceiro não viria consertar as janelas da casa e Stockmann pergunta se o vidraceiro tem medo de consertar suas janelas, Catherine responde:

MRS. STOCKMANN: You don't realize - people don't like to be pointed out. He's got neighbors, I suppose (...) (p.100)

O Naming names é colocado em termos claros aqui e no que virá adiante. Chega uma carta do proprietário dizendo lamentar, mas supostamente "tendo" que despejá-los da casa. Na carta ele diz que odeia fazer isto, mas, que com a opinião pública as coisas são mais difíceis. Mrs. Stockmann diz que, caso sejam despejados, o povo da cidade estará pronto a atacá-los. Miller insere um trecho (inexistente em Ibsen) bastante revelador:

\footnotetext{
${ }^{421}$ [DR. STOCKMANN, olhando para fora: Um garotinho. Olha só ele correndo! Ele pega a pedra. Que rápido o veneno se espalha - até mesmo nas crianças]

${ }^{422}$ Talvez em virtude do que a Shoah e a 'Juventude Hitlerista' foram capazes de mostrar, Miller se mostrava consciente de que o mito da "infância inocente" fosse mais uma falácia social (aliás já demonstrada por Freud muito tempo antes).

${ }^{423}$ [MRS. STOCKMANN: Você não percebe - as pessoas não gostam de serem apontadas. Ele tem vizinhos, eu suponho (...)]
} 
DR. STOCKMANN: Just calm down, will you? We'll go to America, and the whole thing'll be like a dream. $(\text { p.101 })^{424}$

Esta passagem pode ser interpretada de uma outra maneira: "the whole thing will be like a dream", mas qual coisa? Os infortúnios e ataques sofridos até agora ou a chegada deles na América e sua promessa do Sonho Americano? A América, como promessa de respeito à individualidade e à liberdade de expressão, ganha um sentido ainda mais profundo quando lembramos que An Enemy foi encenada no olho do furacão. Um pouco adiante temos outro diálogo que merece ser comentado:

MRS. STOCKMANN: But how do you know it'll be any different there? $($ p.101) 425

DR. STOCKMANN: I don't know. It just seems to me, in a big country like that, the spirit must be bigger. Still, I suppose they must have the solid majority there too. I don't know, at least there must be more room to hide there. $(p .101)^{426}$

Esta fala, bastante sintomática, expressa a esperança de vida na América, mas, ao mesmo tempo ironiza e dá um sentido duplo à esperança, quando diz "pelo menos deve haver mais espaço para se esconder lá". Aqui podemos traçar um paralelo com as pessoas que não declaravam abertamente suas posições políticas e aqueles que, por medo de tortura/desemprego e até morte, tinham que "se esconder". O Dr. Stockmann fala que se descesse a rua, seus amigos "liberais" certamente fingiriam que não o conheciam. Petra entra em cena revelando ter sido afastada de seu trabalho e que sua chefe, mesmo ressentindo ter de demiti-la, "não ousaria" fazer o contrário. Este pequeno termo se torna praticamente o lema daqueles que se conformavam com o status quo. O vidraceiro não ousaria vir consertar as janelas, o proprietário não

\footnotetext{
${ }^{424}$ [DR. STOCKMANN: Se acalme, está bem? Nós iremos para a América, e a coisa toda vai ser como um sonho.]

${ }^{425}$ [MRS. STOCKMANN: Mas como você sabe que será diferente lá?]

${ }^{426}$ [DR. STOCKMANN: Eu não sei. É que parece para mim que, em um país grande como aquele, o espírito deve ser maior. Contudo, eu suponho que eles devam ter a maioria sólida lá também. Eu não sei, pelo menos lá deve haver lugar para se esconder.]
} 
ousaria entrar em conflito com as pessoas da cidade e a diretora de Petra não arriscaria sua reputação/carreira. Dr. Stockmann compara essa atitude como um "naufrágio da civilização" que carregaria como mensagem: "Eles não ousaram". Aqui reside a crítica máxima de Miller: uma alusão à questão de as pessoas submeterem suas consciências para um momento específico. A frase icônica de Lillian Hellman representa com exatidão o que Dr. Stockmann fala sobre "não ousar": "I cannot and will not cut my conscience to fit this year's fashion" ${ }^{272}$. Quando Petra explica as razões de sua demissão, diz que três outras cartas haviam sido enviadas pedindo o seu afastamento, motivo pelo qual ela não poderia culpar inteiramente sua chefe:

\section{DR. STOCKMANN: From whom? (p.103) $)^{428}$ \\ PETRA: They weren't signed. $(p .103)^{429}$}

DR. STOCKMANN: Oh, naturally. The big patriots with their anonymous indignation, scrawling out the darkness of their minds onto dirty little slips of paper - that's morality, and I'm the traitor. What did the letters say? (p.103)

PETRA: Well, one of them was from somebody who said that he'd heard at the club that somebody who visits this house said that I had radical opinions about certain things. $(p .103)^{431}$

DR. STOCKMANN: Oh, wonderful! Somebody heard that somebody heard that she heard, that he heard (...) $(p .103)^{432}$

Na parte inicial deste último trecho, temos a analogia a uma traição a si mesmo, à própria consciência. Aquele que não assina o que escreve prefere não se identificar para não ter de assumir responsabilidade sobre o que está escrito. Logo a seguir, temos outro mecanismo do macarthismo, que é a denúncia sem provas concretas (o que também caracterizou a histeria do

\footnotetext{
${ }^{427}$ SCHREKER, Ellen The Age of McCarthyism: a brief history with documents. 2nd ed. Boston, Bedford/St.Martin's, 2002, p.66. [Eu não posso e não vou moldar a minha consciência à moda desse ano.] 428 [DR. STOCKMANN: De quem?]

${ }^{429}$ [PETRA: Elas não estavam assinadas.]

${ }^{430}$ [DR. STOCKMANN: Oh, naturalmente. Os grandes patriotas com suas indignações anônimas, escrevendo da escuridão de suas mentes em uma tirinha de papel - isto é moralidade e $e u$ sou o traidor. O que diziam as cartas?]

${ }^{431}$ [PETRA: Bem, uma delas era de alguém que disse que tinha ouvido no clube que alguém que visita essa casa disse que eu tinha opiniões radicais sobre certas coisas.]

${ }^{432}$ [DR. STOCKMANN: Oh, maravilha! Alguém ouviu que alguém ouviu que ele ouviu (...)]
} 
período colonial da caça às bruxas, em 1600). Horster, numa atitude amistosa, tenta acalmar Stockmann, dizendo:

HORSTER: (...) In a storm there's just one thing to remember: it will pass.

$(p .104)^{433}$

DR.STOCKMANN: Unless it kills you. $\left(\right.$ p.104) ${ }^{434}$

Aqui o senso idealista de Stockmann parece se tornar um pouco mais realista. O "a não ser que ela te mate" vai muito além de um simples pessimismo, como o leitor pode entender em uma primeira leitura. O que pode ter motivado Miller a inserir este trecho na peça é a dimensão real desta frase $^{435}$. O castigo exemplar, tão comum à sociedade norte-americana desde os tempos de sua fundação ${ }^{436}$, é algo que o macarthismo levou às últimas consequências, tendo inclusive televisionado as audiências. Aliás, essas oitivas e depoimentos foram levados a extremos tais, que ajudaram a levar o senador Joseph McCarthy ao ápice e posteriormente ao declínio. O Dr. Stockmann sentiu-se como se o tivessem marcado como "traidor". Quando Horster faz uma pergunta a Stockmann, enxergamos novamente um aspecto recorrente e determinante das peças de Miller:

HORSTER: What's a word? (p.104) $)^{437}$

DR. STOCKMANN: A word can be like a needle sticking in your heart, Captain. It can dig and corrode like an acid, until you become what they want you to be really an enemy of the people. (p.104) ${ }^{438}$

\footnotetext{
${ }^{433}$ [HORSTER: (...) Em uma tempestade há somente uma coisa a se lembrar: ela passará.] 434 [DR. STOCKMANN: A não ser que ela te mate.]

${ }^{435}$ É amplamente conhecido o efeito devastador que a política persecutória teve sobre algumas pessoas, dentre elas o famoso casal Julius e Ethel Rosemberg (já citado anteriormente), Clifford Odets, Dorothy Comingore etc.

${ }^{436}$ Um importante romance que trata deste período é, sem dúvida, 'The Scarlett Letter', de Nathaniel Hawthorne.

${ }^{437}$ [HORSTER: O que é uma palavra?]

438 [DR. STOCKMANN: Uma palavra pode ser como uma agulha perfurando o seu coração, Capitão. Ela pode cavar e corroer como ácido, até que você se torne o que eles querem que você seja - de fato um inimigo do povo.]
} 
O aspecto recorrente e determinante da dramaturgia milleriana ao qual nos referimos é defesa do nome e honra, que é escancarada neste trecho. $O$ Dr. Stockmann percebe o poder corrosivo das palavras em nomear coisas e, portanto, caracterizá-las. O Blacklisting fazia exatamente isto: ao apontar nomes roubava a dignidade das pessoas e lançava novas reputações odiáveis. O Capitão Horster revela que também fora demitido, pois seu chefe, Mr. Vik, pertencia ao mesmo partido que o do prefeito (Peter Stockmann), o que demonstra a rede de retaliações que se configurou aos que eram culpados por apoiar (mesmo que indiretamente) os acusados de traição.

Peter decide conversar com o irmão e pede que este assine um documento dizendo que as pessoas podem frequentar o balneário. Isso the permitirá ter seu emprego e reputação de volta, mas, Stockmann se recusa e escancara o mecanismo manipulador das autoridades de sua cidade (e também, por analogia, daqueles do macarthismo):

DR. STOCKMANN: You expect me to remain in charge while people are being poisoned? (p.107) $)^{439}$

DR. STOCKMANN: (...) You know your trouble, Peter? You just don't graspeven now - that there are certain men you can't buy. (p.108) $)^{440}$

De maneira análoga, Chris Keller em All My Sons, também não se deixa comprar pelas tentativas de desculpa (e de oferta de emprego) do pai. Jim Bayliss atesta isso ao dizer que algumas pessoas têm talento para mentir, mas que Chris não. Stockmann afirma exatamente que sua consciência não poderia ser comprada, ao contrário do que se via nos Estados Unidos dos anos 1950. Peter insiste dizendo que Dr. Stockmann não é esse tipo de homem (que não pode ser comprado) e revela que seu sogro, Kiil, saíra pela cidade comprando ações de Kirsten Springs, dando a entender que Stockmann buscou desmoralizar o balneário para que seu sogro e ele comprassem juntos a maior fonte de rentabilidade da cidade. À época do macarthismo, a questão

\footnotetext{
${ }^{439}$ [DR. STOCKMANN: Você espera que eu fique responsável enquanto pessoas estão sendo envenenadas?]

${ }^{440}$ [DR. STOCKMANN: (...) Você sabe qual é o seu problema, Peter? Você simplesmente não compreende - mesmo agora - que há certos homens que você não consegue comprar.]
} 
da paranoia e conspiração eram as armas que as autoridades tinham para exorcizar o inimigo externo e interno. Além disso a acusação feita por autoridades como a HUAC e seu modo de exercer o poder normalmente levava os "culpados" a aceitar algum tipo de suborno/acordo. Acusar o outro (name names) isentava muitos de responsabilidade e reafirmava lealdade e patriotismo. Peter Stockmann tenta fazer um acordo/exigência com Thomas:

PETER STOCKMANN: Now go to your desk and write me a statement denying everything you've been saying, or... (p.109) ${ }^{441}$

PETER STOCKMANN: (...) the morning it's published I'll send out a subpoena for you and begin a prosecution for conspiracy. l've been trying to make you respectable all my life; now if you want to make the big jump there'll be nobody there to hold you back. (p.109) ${ }^{442}$

No original, Peter Stockmann conclui sua fala dizendo apenas ter uma arma contra Thomas. Já em Miller, o termo "subpoena" mostra o que se passou durante o macarthismo: atos levados até as últimas consequências para garantir a destruição de um cidadão. Era muito comum os suspeitos serem intimados a depor (caso de Arthur Miller) e se submeterem às violações de direitos humanos básicos.

Logo depois descobrimos que a poluição vem da propriedade de Kiil e que ele herdara do pai, que por sua vez herdara de seu pai (avô) que havia herdado de seu avô (bisavô). Ele diz não querer ver o nome de seus antepassados e o seu próprio envolvidos num crime, e diz que Stockmann precisa salvar as águas. Stockmann lamenta dizendo ser tarde para isso e conta que Kiil havia jogado dinheiro fora. Daí temos uma revelação:

KIIL: I never throw my money away, Thomas. These were bought with your money. (p.111)

\footnotetext{
${ }^{441}$ [PETER STOCKMANN: Agora vá à sua mesa e me escreva uma declaração negando tudo o que você tem dito, ou...]

442 [PETER STOCKMANN: (...) Na manhã em que for publicado, eu vou mandar uma intimação para você e começar um processo por conspiração. Eu tenho tentado fazer você respeitável toda a minha vida, agora, se você quiser dar o grande salto não haverá ninguém lá para te dar apoio.]

${ }^{443}$ [KIIL: Eu nunca jogo dinheiro fora, Thomas. Isso foi comprado com o seu dinheiro.]
} 
KIIL: People call me "badger", and that's an animal that roots out things, but it's also some kind of a pig, I understand. I've lived a clean man and I'm going to die clean. You're going to clean my name for me $(p .112)^{444}$.

Kiil $^{445}$ coloca Stockmann em uma situação delicada, pois, continuar afirmando que as águas estão poluídas implica em condenar a família e a si mesmo à falência. Kiil procura de todas as formas mudar a opinião (inclusive a científica) de Stockmann, levantando a hipótese de que poderia haver alguma coisa anormal exatamente no dia da coleta da amostra para examinar a água. Kiil se apropria do discurso científico e assume uma posição de especialista no assunto e termina dizendo:

KIIL: (...) You admit there's some doubt in your mind about the water, you admit there may be ways to disinfect it, and yet you went after your brother as though these doubts didn't exist. (p.114) 446

A revelação de Kiil é um elemento que vem para mostrar que ambas as esferas (coletiva e individual) estão justapostas e tenta colocar Stockmann à prova para ver se, mesmo com a questão do dinheiro, o doutor não venderá sua consciência. Segundo Leme, este é o segundo elemento caro à dramaturgia milleriana e que se aproxima fortemente às concepções dramatúrgicas da tragédia. Kiil conclui defendendo seu nome e sua honra (o primeiro elemento já mencionado anteriormente), mas neste caso a questão não está vinculada a um ideal e sim à questão financeira:

KIIL: Nobody is going to say Morten Kiil wrecked this town. (p.115) ${ }^{447}$

\footnotetext{
${ }^{444}$ [KIIL: As pessoas me chamam de "texugo", e esse é um animal que enraíza coisas, mas é também um tipo de porco, pelo que eu entendo. Eu tenho uma reputação limpa e vou morrer com ela limpa. Você limpará meu nome para mim.]

${ }^{445}$ Seu apelido 'badger', 'texugo', em português, caracteriza-se por ser um animal carnívoro da família dos gambás e que possui um comportamento agressivo. O texugo, que abriga-se no subterrâneo, mantém a sua presa com uma tenacidade máxima e é um animal bastante feroz que protege seus jovens a qualquer preço. Para se ter uma ideia, os texugos são capazes de repelir animais muito maiores como raposas, lobos, coiotes e ursos. Diferentemente de muitos carnívoros que atacam suas presas espreitando-as em campo raso, os texugos conseguem a maior parte da sua comida por meio de escavação da terra. Eles conseguem cavar túneis profundos onde escondem a comida.

${ }^{446}$ [KIIL: Você admite que há alguma dúvida na sua cabeça em relação às águas, você admite que há maneiras de limpá-la, e ainda assim você foi atrás do seu irmão como se essas dúvidas não existissem.]

${ }^{447}$ [KIIL: Ninguém vai dizer que Morten Kiil destruiu essa cidade.]
} 
KIIL: (...) I want my good name. It's exceedingly important to me. $(p .115)^{448}$

Aslaksen e Hovstad entram em cena e dizem a Stockmann que o jornal pode lhe ser útil para limpar seu nome mas o que estava por trás do gesto aparentemente amigável dos dois era buscar alguém que pagasse pelas despesas de impressão. Hovstad diz que o jornal será importante para ele, pois seu irmão o processará por conspiração e ele certamente terminará preso. Visto que Stockmann não cederia, Hovstad conclui:

HOVSTAD, looking directly at Dr. Stockmann: You're a madman. You are insane with egotism. And don't excuse it with humanitarian slogans, because a man who'll drag his family through a lifetime of disgrace is a demon at heart! (...) A demon who cares more for the purity of a public bath than the lives of his wife and children. (p.119-120) ${ }^{449}$

A recusa em cooperar geraria problemas, e muitos, durante 0 macarthismo foram acusados de desacato por não colaborarem com as autoridades. Este, por sinal, foi o caso do próprio Miller quando disse a Richards Arens (que the fazia perguntas durante o depoimento) que não responderia dando nomes de pessoas que pudessem estar envolvidas com o comunismo:

Mr.Chairman, I understand the philosophy behind this question and I want you to understand mine. When I say this I want you to understand that I am not protecting the Communists or the Communist Party. I am trying to and I will protect my sense of myself. I could not use the name of another person and bring trouble on him. These were writers, poets, as far as I could see, and the life of a writer, despite what it sometimes seems, is pretty tough. (The witness confers with his counsel) I will tell you anything about myself, as I have... I will be perfectly frank with you in anything relating to my activities. I take the

\footnotetext{
448 [KIIL: Eu quero meu bom nome. É extremamente importante para mim.]

449 [HOVSTAD, olhando diretamente para Dr. Stockmann: Você é um louco. Você é um louco egoísta. E não arranje desculpas com slogans humanitários, porque um homem que vai arrastar sua família para uma vida de desgraças é um demônio em essência! (...) Um demônio que se importa mais com a pureza de um balneário público do que com as vidas de sua esposa e filhos.]
} 
responsibility for everything I have ever done, but I cannot take responsibility for another human being. ${ }^{450}$

Neste mesmo instante chegam Ejlif e Morten da escola e relatam brigas (Morten chega com um ferimento na cabeça) e afastamento (a professora recomendou que eles ficassem afastados por uma semana). Stockmann se irrita e, ao mesmo tempo em que expulsa os rapazes da imprensa de sua casa, declara:

DR. STOCKMANN: They want me to buy the paper, the public, the pollution of the springs, buy the whole pollution of this town! They'll make a hero out of me for that (...). But I'm not a hero, I'm the enemy - and now you're first going to find out what kind of enemy I am! I will sharpen my pen like a dagger - you, all you friends of the people, are going to bleed before I'm done! Go, tell them to sign the petitions! Warn them not to call me when they're sick. Beat up my children! And never let her - he points to Petra - in the school again or she'll destroy the immaculate purity of the vacuum! See to all the barricades - the truth is coming! Ring the bells, sound the alarm! The truth, the truth is out, and soon it will be prowling like a lion in the streets! (p.122-123) ${ }^{451}$

O Dr. Stockmann expressa uma outra importante característica da dramaturgia milleriana (o terceiro elemento recorrente de sua dramaturgia) que é a relação entre causa e efeito. O Dr. Stockmann estende a análise de sua possível ação ao plano das consequências: ao se comprar o jornal e o público se está também comprando a poluição de toda a cidade (literal e

\footnotetext{
${ }^{450}$ MURPHY, Brenda. Congresstional Theatre: Dramatizing McCarthyism on Stage, Film, and Television. Cambridge, Cambridge University Press, 1999, p.68. [Senhor Presidente, eu entendo a filosofia por trás dessa pergunta e eu quero que você entenda a minha. Quando eu digo isso, eu quero que você entenda que eu não estou protegendo comunistas ou o Partido Comunista. Eu estou tentando e vou proteger o meu senso de mim mesmo. Eu não poderia usar o nome de outra pessoa e trazer problemas para ela. Eram escritores, poetas, tanto quanto eu podia ver, e a vida de um escritor, apesar do que parece às vezes, é muito difícil. (A testemunha confere com seu defensor) Vou lhe dizer qualquer coisa sobre mim, como eu tenho feito... Vou ser sincero com você em qualquer coisa relacionada com as minhas atividades. Eu assumo a responsabilidade por tudo o que já fiz, mas não posso assumir a responsabilidade por outro ser humano.]

${ }^{451}$ [DR. STOCKMANN: Eles querem que eu compre o jornal, o público, a poluição das águas, compre toda a poluição desta cidade! Eles vão fazer de mim um herói por isso (...). Mas eu não sou um herói, eu sou o inimigo - e agora vocês serão os primeiros a descobrir que tipo de inimigo eu sou! Vou afiar a minha caneta como a uma adaga - a todos vocês, amigos do povo, vão sangrar antes de eu terminar! Vá, diga-lhes para assinar as petições! Avise-os para não me chamar quando estiverem doentes. Espanquem meus filhos! E nunca deixem que ela - ele aponta para Petra - entre na escola de novo ou ela vai destruir a pureza imaculada do vazio! Preparem as barricadas - a verdade está chegando! Toquem os sinos, soem o alarme! A verdade, a verdade, a verdade está lá fora, e em breve estará rondando como um leão nas ruas!]
} 
figurativamente). Stockmann decide manter-se leal a seus ideais e à verdade e desafia a maioria dizendo que eles podem até assinar a petição. Assim como John Proctor, de The Crucible, Stockmann não está disposto a vender sua consciência, assinando de maneira simbólica, seu atestado de óbito. Aliás, a questão da consciência e das escolhas feitas é central na dramaturgia milleriana. Esta noção aproxima Miller de Camus e o afasta de Sartre. Um exemplo breve e interessante a ser mencionado é quando Jean Paul Sartre resolve adaptar The Crucible para o cinema com uma versão marxista que transformava a peça numa questão de luta de classes entre camponeses ricos e pobres ${ }^{452}$.

Miller esclarece, em Timebends ${ }^{453}$, que em hipótese alguma Rebecca Nurse e John Proctor poderiam ser considerados pobres. Eles eram, ao contrário, proprietários rurais. Concluímos com a fala de Feldman que:

O que estava em jogo em Salém não era unicamente a posse de terra, mas a posse de alma, isto é, de consciência, de domínio sobre a definição de verdade e de justiça. ${ }^{454}$

Assim sendo, o coletivo para Miller é a consciência e o entendimento (alcançado com a queda), e não necessariamente a luta de classes. Sua busca era a de levantar responsabilidade sobre o outro sem o uso de violência, ponto que 0 fez afastar-se de Sartre ${ }^{455}$ e aproximar-se das ideias de Camus que reconhece em suas obras que os meios não justificam os fins e delineia a possibilidade de que o homem pode resistir ao mundo. Retornando à $A n$

\footnotetext{
${ }^{452}$ O filme fora adaptado na versão supracitada com o título de "Les sorcières de Salem”, em 1957, com direção de Raymond Rouleau. O filme, apesar de focar na questão da posse de terras por motivações privadas, se distancia em diversos pontos da peça original. Um exemplo curioso é que Elizabeth (esposa de John Proctor) salva Abigail de um linchamento e as pessoas da cidade se levantam contra Thomas Danforth, o qual se torna o principal antagonista.

${ }^{453}$ MILLER, Arthur. Timebends. op.cit., p.349.

${ }^{454}$ FELDMAN, Alexandre. op.cit., p.209.

${ }^{455}$ A ênfase marxista dada por Sartre, de certa maneira, impediu que a opção individual (o livre arbítrio) viesse à tona.
} 
Enemy: é justamente sua maior aspiração que o destrói e o torna um herói de tragédia liberal. Permanecendo firme em seus ideais Stockmann decide que os filhos não irão mais à escola e que ele e Petra lhes darão aulas:

DR. STOCKMANN: (...) Boys, no more school. I'm going to teach you, and Petra will. Do you know any kids, street louts, hookey players - (p.124) ${ }^{456}$

DR. STOCKMANN: We'll want about twelve of them to start. But I want them good and ignorant, absolutely uncivilized. (p.124) $)^{457}$

DR. STOCKMANN: (...) we'll turn out not taxpayers and newspaper subscribers, but free and independent people, hungry for the truth. (p.124)

Stockmann reconhece a derrota perante a sociedade, mas acredita ser possível salvar gerações mais novas, cuja consciência ainda não foi comprada. A peça termina com metade da cidade do lado de fora de sua casa apedrejando-a, o que caracteriza um conflito cerrado na perspectiva de Lesky. A tragédia se configura com um caráter liberal, pois Stockmann precisou se destruir para se preservar. Encerra, pois, a peça dizendo:

DR. STOCKMANN: (...) remember now, everybody. You're fighting for the truth, and that's why you're alone. And that makes you strong. We're the strongest people in the world... (p.124-125) $)^{459}$ DR. STOCKMANN: ... and the strong must learn to be lonely! $!^{460}$

A frase emblemática do final da peça em lbsen encontra uma pequena diferença. No original, temos uma pequena diferença que vale a pena ser comentada:

\footnotetext{
${ }^{456}$ [DR. STOCKMANN: Meninos, chega de escola. Eu vou ensinar vocês e a Petra também. Vocês conhecem alguma criança, garotos de rua, jogadores de Hookey -]

${ }^{457}$ [DR. STOCKMANN: Nós vamos precisar de mais ou menos doze deles para começar. Mas eu os quero bons e ignorantes, absolutamente não-civilizados.]

${ }^{458}$ [DR. STOCKMANN: (...) Nós vamos virar não contribuintes e assinantes de jornal, mas pessoas livres e independentes, famintos pela verdade. ]

459 [DR. STOCKMANN: Lembrem-se agora, pessoal. Vocês estão lutando pela verdade, e é por isso que estão sozinhos. E isso faz vocês fortes. Nós somos as pessoas mais fortes do mundo...]

${ }^{460}$ [DR. STOCKMANN: ... e os fortes precisam aprender a ser só.]
} 
DR. STOCKMANN: (...) now I'm the strongest man in the world. (versão de Ibsen, p.82) ${ }^{461}$

DR. STOCKMANN: (...) the strongest man in the world is he who stands most alone. (versão de Ibsen, p.82) ${ }^{462}$

A alteração feita por Miller engloba uma dimensão coletiva (We), simbolizando uma luta coletiva, social e plural. Já em lbsen, tem-se a impressão de que a luta de Stockmann engloba mais o individual (I), sendo a luta de um homem pela verdade. Muitos críticos, inclusive, consideraram a peça de lbsen uma comédia, cujo protagonista luta patética e individualmente por uma verdade motivada não somente por questões de ordem pública, mas, privada. O idealismo e inocência de Stockmann parecem surreais, pois dão a impressão de que um personagem lunático vai contra uma mentira. Miller deixa clara que a luta deste indivíduo (Dr. Stockmann) é a luta de um coletivo (ou pelo menos deveria sê-lo) em busca da verdade, em busca do direito a opor-se à mentalidade comum e à mentira. Miller comenta em Timebends que deveria ser encorajado a declarar, assim como Ibsen, que "o mais forte é aquele que está só”, mas sua judeidade o afastou da salvação pessoal como algo próximo ao pecado.

A situação trágica atingida por Stockmann na peça possui um efeito irrevogável: à medida que o seu poder político é reduzido a zero, o seu poder literário cresce a ponto de dominar toda a cena. Desta maneira Arthur Miller (e Ibsen, obviamente), com seu teatro político, explicita corajosamente durante o macarthismo não somente o que a sociedade é, mas sua dinâmica, sua luta e sua evolução.

\footnotetext{
${ }^{461}$ IBSEN, Henrik. An Enemy of the People. op.cit.. [DR. STOCKMANN: (...) agora eu sou o homem mais forte do mundo.]

${ }^{462}$ Ibidem. [DR. STOCKMANN: (...) o homem mais forte do mundo é aquele que está mais sozinho.]
} 


\subsection{RUBRICAS}

O uso das rubricas em An Enemy of the People, é de fundamental importância não somente para que o conhecimento sobre a natureza das personagens seja aprofundado (assim como em All My Sons) como para que estas sejam situadas dentro da dramaturgia Ibseniana e dentro do contexto do macarthismo. Quando Miller, insere Kiil já desde a primeira cena da peça (coisa que não acontece em lbsen), temos a descrição de uma ação não-verbal bastante curiosa:

Kiil starts across to the front door. Billing returns to his food in the dining room. Kiil halts at the bowl of apples; he takes one, likes it, takes another and puts it in his pocket, then continues on toward the door. Again he stops, returns, and takes another apple for his pocket. Then he sees a tobacco can on the table. He covers his action from Billing's possible glance, opens the can, smells it, pours some into his side pocket (...) $(\text { p. } 17-18)^{463}$

Tal ação já mostra destarte que Kiil é uma personagem que faz coisas sorrateiramente (típica do texugo, mencionado antes) e seu apelido "badger" confirma sua avidez e ganancia em ter coisas. Miller coloca-o já no início, sem verbalizar nada, e mesmo hesitando, Kiil faz aquilo que deseja e tenta manterse longe de ser descoberto. Na segunda cena ainda do primeiro ato que se passa na manhã seguinte ainda na casa dos Stockmann, Morten Kiil, está novamente presente. A caracterização desta última personagem (assim como a descrição feita a respeito de Petra, que será comentada adiante) revela a base sob a qual se apoia a dramaturgia de Ibsen:

Morten Kiil sticks his head through the doorway. He looks around searchingly and chuckles. He will continue chuckling until he leaves the house. He is an archetype of the little twinkle-eyed man who sneaks into so much of Ibsen's

\footnotetext{
463 [Kiil vai em direção à porta da frente. Billing retorna à sua comida na sala de jantar. Kiil para na bacia de maçãs, ele pega uma, gosta, pega outra e a coloca em seu bolso, em seguida, continua em direção à porta. Mais uma vez ele para, volta, e pega outra maçã e a põe em seu bolso. Então ele vê uma lata de tabaco em cima da mesa. Ele encobre a ação do possível olhar de Billing, abre a lata, a cheira, derrama um pouco no bolso do lado (...)]
} 
work. He will chuckle you right over the precipice. He is the leader, the man with the rat's finely tuned brain. But he is sometimes likable because he is without morals and announces the fact by laughing. (p.40) ${ }^{464}$

Aqui fica evidente uma vez mais a natureza de Kiil: uma personagem caricata que se diverte com fatos trágicos e escândalos, e se apresenta como um espectador que se vê fora do que acontece. Seu senso amoral (e não imoral) espelha o homem comum que, na sua ignorância, não se vê conectado ao todo. Rouba maçãs e tabaco, dá risada, gosta de situações de rivalidade e se comporta como se a esfera coletiva estivesse fora dele. Contudo, quando se confirma a poluição das águas, a esfera pública o obriga a enxergar a conexão desta mesma com a privada: Kiil compra as ações do balneário para que este não seja fechado.

A rubrica que descreve Peter Stockmann também merece, mesmo que brevemente, ser comentada:

Peter Stockmann, the Mayor, enters. He is a bachelor, nearing sixty. He has always been one of those men who make it their life work to stand in the center

of the ship to keep it from overturning. He probably envies the family life and warmth of this house, but when he comes he never wants to admit he came and often sits with his coat on (p.18-19) ${ }^{465}$.

A característica fundamental de Peter é que este dedica sua vida ao trabalho. Peter é, na peça, uma personagem central que em seu delírio de grandeza, torna caótica a situação distorcendo (a seu gosto) motivações privadas e públicas. Enxergando-se como o "prefeito", Peter Stockmann aniquila-se enquanto pessoa e enxerga na sua função de autoridade uma devoção total que garante seu poder moral. Mesmo em um ambiente familiar (âmbito privado), comporta-se como uma pessoa pública e mantém-se vestido

\footnotetext{
${ }^{464}$ [Morten Kiil enfia a cabeça pela porta. Ele olha em volta de maneira investigativa e da risada. Ele vai continuar rindo até que ele saia da casa. Ele é um arquétipo do homem pequeno com brilho nos olhos que anda furtivamente em muito da obra de Ibsen. Ele vai rir até cair no precipício. Ele é o líder, o homem com cérebro afinado do rato. Mas às vezes é simpático, porque ele é sem moral e anuncia o fato, rindo.] ${ }^{465}$ [Peter Stockmann, o prefeito, entra. Ele é solteiro, aproximando-se dos sessenta anos. Ele sempre foi um daqueles homens que fazem da vida o trabalho para ficar no centro do navio, para evitar que ele não seja derrubado. Ele provavelmente inveja a vida familiar e o calor da casa, mas quando ele vem, ele nunca quer admitir que veio e muitas vezes fica com o casaco vestido.]
} 
com seu casaco para que não se mostre integrado ou descontraído naquele ambiente ao qual, a seu ver, não pertence.

Uma outra rubrica, que descreve Hovstad, aprofunda a natureza dessa personagem central para a peça e elucida o mecanismo em que muitos dos colaboradores do macarthismo, os informantes, se apoiavam:

HOVSTAD: a graduate of the peasantry struggling with a terrible conflict. For while he hates authority and wealth, he cannot bring himself to cast off a certain desire to partake them. Perhaps he is dangerous because he wants more than anything to belong, and in a radical that is a withering wish, not easily to be borne (p.20) ${ }^{466}$.

A rubrica nos diz que ele talvez seja perigoso, pois seu desejo de pertencimento pode levá-lo a assumir diferentes posições de acordo com o que Ihe convém no momento, tão comum aos tempos do macarthismo. A sedução pelo poder é algo que está fortemente marcado nesta personagem, assim como esteve em muitos outros que se viram na obrigação cívica de denunciar. O repúdio inicial e explícito de Hovstad à autoridade e às questões que a permeavam travestiam uma plasticidade em seu caráter que apontava que tal frustração, no final, era um desejo de pertencer. Sua radicalidade, seus ideais e sua consciência são facilmente manipuláveis quando se cogita a possibilidade de a esfera coletiva impactar a individual. Miller, ao descrevê-lo de tal maneira, explicita que nem mesmo aqueles que teoricamente eram marcados por uma rigidez e confiança naquilo que acreditavam, escapariam à "conversão" aos ditames das autoridades. The Crucible, por exemplo, com seu título ilustra essa ideia brilhantemente.

Quando Dr. Stockmann entra em cena, Miller o descreve da seguinte forma:

\footnotetext{
${ }^{466}$ [Hovstad: um pós graduado dos camponeses lutando com um conflito terrível. Ao mesmo tempo em que ele odeia autoridade e riqueza, ele não consegue abandonar um certo desejo de participar delas. Talvez ele seja perigoso, porque ele quer mais do que qualquer coisa pertencer, e sob um princípio que é um desejo intimidante, e não é fácil de ser suportado].
} 
(...) He might be called the eternal amateur - a lover of things, of people, of sheer living, a man for whom the days are too short, and the future fabulous with discoverable joys. And for all this most people will not like him - he will not compromise for less than God's own share of the world while they have settled for less than Man's (p.23) ${ }^{467}$.

A caracterização psicológica de Stockmann evidencia sua natureza sonhadora, mas, ao mesmo tempo, correta. Stockmann é descrito como um homem apaixonado pela vida e que não se contenta em 'settle for half $f^{468}$. O fato que Miller menciona que a maioria das pessoas não gostará de Stockmann se confirma nas críticas que Ibsen recebeu quando estas diziam que Stockmann era uma personagem cômica e patética. Sua consciência e valores éticos, contudo, serão o alicerce de sua defesa de princípios pelos quais ele lutará mais à frente.

A rubrica que caracteriza a personagem Capitão Horster é valiosa e confirma sua conduta durante toda a peça. Aparentemente uma personagem alienada, que procura fugir de questões políticas, o Capitão Horster é uma personagem central e fundamentalmente importante. Miller o descreve da seguinte maneira:

Captain Horster is one of the longest silent roles in dramatic literature, but he is not to be thought of as a characterless therefore. It is not a bad thing to have a courageous, quiet man for a friend, even if it has gone out of fashion. (p.29) ${ }^{469}$

A personagem não deve ser considerada como sendo sem caráter, pois o não-posicionamento aberto dele não implica que ele não tenha um posicionamento. Muito pelo contrário, Horster mantém um certo silêncio e suas convicções/dúvidas políticas para consigo mesmo são como uma maneira de

\footnotetext{
${ }^{467}$ [(...) Ele pode ser chamado de amador eterno - um amante das coisas, das pessoas, da vida pura, um homem para quem os dias são muito curtos, e o futuro fabuloso com alegrias detectáveis. E por tudo isso a maioria das pessoas não gostará dele - ele não irá se contentar por menos da própria parte do mundo de Deus, enquanto outros aceitam tudo por menos.]

${ }^{468}$ Termo corroborado da personagem Alfieri, em A View from the Bridge.

${ }^{469}$ [Capitão Horster é um dos mais longos papéis silenciosos em literatura dramática, mas ele não deve ser pensado como sem caráter. Não é uma coisa ruim ter um homem quieto e corajoso como amigo, mesmo que isso tenha saído de moda.]
} 
preservar quem ele é, e de não filiar-se à ideologia corrente simplesmente por ser aquela a que todos aderem. Como já mencionamos, Horster se aproxima fortemente da imagem do 'Fellow Traveler'.

Quando Petra, filha de Stockmann, entra em cena, sua caracterização na rubrica é importante, pois não somente explica algo sobre a personagem, mas a contextualiza dentro da dramaturgia ibseniana:

Petra in hat and coat and with textbooks and notebooks under her arm comes into the entrance hall. She is Ibsen's clear-eyed hope for the future - and probably ours. She is forthright, determined, and knows the meaning of work, which to her is the creation of good on the earth. (p.32) ${ }^{470}$

A descrição que Miller faz dela a situa dentro da dramaturgia ibseniana como a personagem que é fiel a seus ideais e que possui uma visão de mundo bastante clara e politizada. É ela a personagem mais coerente e inquisidora no sentido ético e moral: Petra, em nome da verdade contida na afirmação de seu pai, não teme retaliação alguma, explica à mãe que a verdade deve ser dita, confronta o tio e os rapazes da imprensa liberal diretamente e lecionará aos irmãos quando estes sofrerem violência na escola. Petra tem a coragem de agarrar-se à verdade sem utopias ou idealismos, e seu interesse e ofício voltados ao mundo letrado remetem à ideia da busca pelo conhecimento e esclarecimento das coisas.

Uma última rubrica que merece ser comentada aparece no momento em que Dr. Stockmann, após sofrer retaliação por parte de seus "amigos" da imprensa, sai pela porta. A decisão de imprimir o manuscrito elaborado pelo prefeito, e não pelo Dr. Stockmann, é concluída de maneira emblemática (e inédita, na versão de Miller):

\footnotetext{
${ }^{470}$ [Petra vestindo chapéu e casaco e com livros didáticos e cadernos debaixo do braço vem para o hall de entrada. Ela é a "esperança de olhos claros", de Ibsen para o futuro - e, provavelmente, a nossa. Ela é franca, determinada e sabe o significado do trabalho, o que para ela é a criação de bom na terra.]
} 
Peter Stockmann looks regretfully toward the exit, then takes out his manuscript and hands it to Hovstad, who in turn gives it to Billing, who hands it to Aslaksen, who takes it and exits. Peter Stockmann puts his hat on and moves toward the door. Blackout. The curtain falls. (p.80) ${ }^{471}$

Esta passagem introduz a convicção sartreana recorrente de Miller de que todos possuem a culpa: seja ela por participação ou por conivência. Este gesto não-verbal fala simbolicamente sobre o engajamento, a mútua participação (direta ou indireta) nas questões de responsabilidade. Este gesto inserido por Miller, ecoa as palavras de Desmond Tutu, ganhador do Nobel da Paz em 1984, quando diz:

"If you are neutral in situations of injustice, you have chosen the side of the oppressor" ${ }^{\mathrm{4} 72}$.

\subsection{PERSONAGENS}

Miller manteve as personagens originais de lbsen sem alterações de nomes, mas, com algumas caracterizações psicológicas um pouco diversas das de Ibsen. Também, em dados momentos, as deslocou de cenas, como é o caso da cena inicial da peça.

Ao subir o pano encontramos Kiil em cena, coisa que não acontece no original de Ibsen, no qual se encontram presentes apenas Billing e Mrs.Stockmann. Miller nos descreve que Kiil é uma personagem que sabe o que faz, pois ao pegar tabaco tenta impedir Billing de vê-lo fazendo isto. $\mathrm{Na}$ cena, Kiil rouba maçãs e é mostrado como como alguém que faz coisas

\footnotetext{
${ }^{471}$ [Peter Stockmann olha com pesar para a saída, então tira o seu manuscrito e o entrega para Hovstad, que por sua vez o dá para Billing, que o entrega para Aslaksen, que toma e sai. Peter Stockmann coloca seu chapéu e se move em direção a porta. Blackout. O pano cai.]

${ }^{472}$ TUTU, Desmond. In: Ending Poverty As We Know It: Guaranteeing a Right to a Job at a Living Wage (2003) by William P. Quigley, p. 8. [Se você é neutro em situações de injustiça, você escolheu o lado do opressor.]
} 
sorrateiramente, colocando o espectador desde o primeiro momento de frente a uma personagem que não é tão inocente.

Peter Stockmann é uma personagem que incorpora a contradição entre a figura pública e privada. Este é um homem que dedica sua vida ao trabalho e quando se encontra em uma situação privada, confunde sua figura individual com a pública. Este é um dos tipos mais perigosos, pois o trabalho (e os interesses inerentes a ele) estão acima de tudo e sua dedicação resultará no que for preciso. O poder que o status lhe dá é confirmado por atitudes como sentar com o casaco, e não aceitar comer nada que lhe é oferecido a fim de que não misturem as coisas, afinal, ele é o prefeito. A primeira cena entre Peter Stockmann e Hovstad, marca fortemente a caracterização de ambos. Quando tenta se lembrar do nome do jornal para o qual Hovstad trabalha, Peter Stockmann pergunta de maneira condescendente:

PETER STOCKMANN: (...) the People's Daily Liberator? $(p .20)^{473}$ HOVSTAD: People's Daily Messenger. (p.20) ${ }^{474}$

Nesta fala aparentemente trivial, ficam claras as diferentes concepções do que o jornal faz: enquanto um (Peter) pressupõe um jornal cujo título remete a ações (liberação), o outro (Hovstad) se coloca de forma "neutra" como passador de informações (mensageiro). Mesmo assim, Peter critica o jornal por entender que este possa ser "culpado por associação":

PETER STOCKMANN: I don't want you to think I blame the Doctor for using your paper. After all, every performer goes for the audience that applauds him most $(. ..)(\text { p.20) })^{475}$

Foi notável durante o macarthismo o número de pessoas acusadas de comunismo ou de serem antipatrióticos por apoiar indiretamente os

\footnotetext{
473 [PETER STOCKMANN: (...) o 'Libertador Cotidiano do Povo'?]

474 [HOVSTAD: O 'Mensageiro Cotidiano do Povo'.]

475 [PETER STOCKMANN: Eu não quero que você pense que eu culpo o Doutor por usar o seu jornal. Afinal de contas, cada artista vai para o público que mais o aplaude (...)]
} 
"criminosos" e/ou dissidentes. Os simpatizantes eram pressionados e torturados (psiquica e fisicamente) para que aprendessem a ser patriotas. Aliás, o patriotismo que une (e cinde) as personagens de An Enemy se dá pela atividade que traz dinheiro à cidade: o balneário. Peter Stockmann não vê separação entre ideias e motivação financeira (dinheiro) e sua posição social e financeira determinam sua visão e ação. Sua visão de prefeito e executor de tarefas (pelo menos em teoria) cinde um homem de ideias e um homem de ações:

PETER STOCKMANN: My good brother is never at loss for ideas. All sorts of ideas. But, when it comes to putting them into action you need another kind of man (...) (p.22) ${ }^{476}$

Peter recorre a esta ideia de que um homem de ideias não é suficiente para por um serviço em prática e que este trabalho demanda outro tipo de homem, reivindicando créditos por sua participação e dedicação quase que exclusiva ao trabalho. Peter diz que o balneário deve ser tratado de maneira comercial, insinuando que a questão irá para o lado pessoal e que seu irmão fará coisas sem que ele saiba. Aqui vemos uma mistura de questões de ordem pública (o balneário) com questões privadas (medo de o irmão tramar contra ele). Este sentimento paranoico que incomoda pela ameaça de subversão foi bastante comum aos tempos do macarthismo. Em uma sociedade "bem organizada", como diz Peter, uma pessoa que tem vontade própria não se dará bem. Já que a sociedade é "bem organizada", é preciso conformar-se e confiar naqueles que detêm o poder.

O Dr. Stockmann, apesar de ser sonhador e idealista é, paradoxalmente, uma das personagem mais realistas da peça (isto ficará mais claro posteriormente). Seu conhecimento da estrutura social o leva a culpá-la pelo mal que recai sobre ele e sobre os cidadãos da cidade. Joe Keller também enxerga na sociedade um motivo para culpá-la, mas, com intenções diferentes. Feldman comenta que:

\footnotetext{
${ }^{476}$ [PETER STOCKMANN: Ao meu bom irmão nunca faltam ideias. Todo o tipo de ideias. Mas, quando chega a hora de colocá-las em ação você precisa de um outro tipo de homem (...)]
} 
(...) a consciência em Stockmann pretendia manter o tecido social unido em torno de algo que representasse o bem comum. Já Keller usava a estrutura da sociedade como desculpa por suas atitudes individuais que tinham a competição como norma e o sucesso pessoal como objetivo maior. ${ }^{477}$

O Dr. Stockmann mostra-se consciente de que seu irmão é quem na verdade sonha e delira ser. Reconhece que Peter é um homem que não se vê separado do trabalho (assim como Joe Keller também não se via):

DR. STOCKMANN: (...) all he knows is official business and duties (...). $(\text { p. } 28)^{478}$

Mrs. Stockmann é mostrada como a esposa obediente: busca bebida, costura e faz perguntas curiosas (mostrando não estar envolvida com o que se passa com o marido). Esta personagem tem características bastante comuns às de outras personagens femininas de Miller, que representam o cidadão médio norte-americano aparentemente alienado. Ao final da peça, entretanto, Mrs. Stockmann parece estar consciente de que a sociedade é corrupta e corruptível e permanece ao lado do marido. Sua atitude conformista inicial, espelha as mães presentes nas peças de Miller, que se aproximam externamente do estereotipo da "dona do lar americana ${ }^{479 " . ~}$

O Capitão Horster, que também se apresenta aparentemente alienado ou desinteressado com questões políticas, é outra personagem que nos chamou a atenção. Quando perguntado se estaria na cidade nas eleições, Horster mostra seu raciocínio:

HORSTER: I don't get mixed up in those things. (p.29) 480 HORSTER: Frankly, I don't understand a thing about it. (p.29)

\footnotetext{
${ }^{477}$ FELDMAN, Alexandre, op.cit, p.28.

${ }^{478}$ [DR. STOCKMANN: (...) tudo o que ele sabe são negócios oficiais e deveres (...)]

${ }^{479}$ Kate, de All My Sons; Linda, de Death of a Salesman e Beatrice, de A View From the Bridge; representam a dona de casa americana aparentemente obediente e tranquila. Esta passividade, contudo, esconde algo que normalmente vem à tona posteriormente. É a tentação da inocência que as condena à queda e, posteriormente, à consciência.

${ }^{480}$ [HORSTER: Eu não me meto nessas coisas.]
} 
Verificamos, todavia, que não é que ele não se interessa por assuntos deste tipo, mas, se não se julga competente para assumir uma posição, como diz logo em seguida:

BILLING: (...) Society, Captain, is like a ship - every man should do something to help navigate the ship. (p.30) $)^{482}$

HORSTER: That may be all right on shore, but on board a ship it doesn't work out so well. $(\text { p.30) })^{483}$

Horster, em sua aparente alienação, parece saber mais do que os outros que se auto intitulam "capitães da sociedade". Horster sabe que as coisas, na prática, não funcionam desta maneira e prefere não falar aquilo que não sabe.

Petra, filha de Stockmann, possui uma relação bastante informal com o pai. Miller insere inclusive uma piada (uma frase cômica) e informal para mostrar a relação dos dois que, no original, não aparece.

DR. STOCKMANN: (...) I look at her and say to myself, 'How did I do it'? $(p .30)^{484}$

O elemento cômico e a relação informal que se apresentam na interação de Stockmann com as outras personagens da peça, confirmam o caráter do 'Common Man', que Arthur Miller defende como sendo um sujeito importante à tragédia. Petra é uma personagem que percebe o que está além do aparente. $\mathrm{Na}$ primeira cena do segundo ato, por exemplo, vai ao escritório editorial para conversar com os amigos "liberais" de seu pai e pergunta-Ihes se seriam

\footnotetext{
481 [HORSTER: Francamente, eu não entendo nada sobre isso.]

482 [BILLING: (...) A sociedade, Capitão, é como um navio - cada homem deveria fazer algo para ajudar a navegá-lo.]

${ }^{483}$ [HORSTER: Isso pode funcionar em terra, mas a bordo do navio isso não funciona tão bem.]

${ }^{484}$ [DR. STOCKMANN: (...) Eu olho para ela e digo a mim mesmo, 'Como eu fiz isso'?]
} 
capazes de publicar algo cujo teor destoaria dos princípios deles. Seu embate com os rapazes e com seu tio (o prefeito) é tão direto e destemido que mostra Petra como uma personagem genuína e firme em seus ideais. Seu poder literário é tão agudo que ela chega a ser aquilo que lbsen (em seu tempo) e Miller (no macarthismo) idealizavam que os cidadãos fossem. O engajamento massivo e histérico das pessoas à ideologia do denuncismo e da acusação se contrapunham ferozmente às atitudes de Petra na peça.

As crianças Ejlif e Morten, filhos dos Stockmann, são apresentados como crianças que não devem ser aproximadas da realidade, pois são jovens para entender. Mrs. Stockmann procura doutriná-los dizendo-lhes que devem escutar seu professor, e evita que os filhos se desviem dos padrões da família tidos como comuns. Em certo momento há um diálogo curioso entre um dos meninos (Morten) e Billing sobre ser Viking e ser pagão e que ilustram o quanto a criança em sua aparente inocência é capaz de fazer opções, mas, ao mesmo tempo, é forçada a se conformar com padrões que se encaixem naquilo que é esperado:

MORTEN: I'm going to be a Viking. (p.32) ${ }^{485}$ EJLIF: You can't! You'd have to be a heathen! $(p .32)^{486}$ MORTEN: So l'll be a heathen. $(p .32)^{487}$

Mrs. Stockmann entra na conversa dizendo ser tarde e querendo interromper a conversa, o que nos traz uma reflexão interessante:

MRS. STOCKMANN, interrupting: Don't you have any homework for tomorrow, boys? Better go in and do it. (p.33) ${ }^{488}$ HOVSTAD: You really think it hurts them to listen to such talk? (p.33) ${ }^{489}$

\footnotetext{
485 [MORTEN: Eu vou ser um Viking.]

486 [EJLIF: Você não pode! Você teria de ser pagão!]

487 [MORTEN: Então eu serei pagão.]

${ }^{488}$ [MRS. STOCKMANN, interrompendo: Vocês não têm lição de casa para fazer, meninos? É melhor vocês entrarem e fazerem.]

${ }^{489}$ [HOVSTAD: Você realmente acha que faz mal a eles ouvir tal conversa?]
} 
MRS. STOCKMANN: I don't know, but I don't like it. $(p .33)^{490}$

O fato de Mrs. Stockmann não gostar de tal ideia aponta, novamente, para sua caracterização conformista e desejosa de estar adaptada ao status quo. Pensando analogamente em relação ao macarthismo, Catherine parece temer que qualquer ideia ou atitude subversiva penetre a estrutura de sua família.

Kiil, sogro de Stockmann, é uma das personagens mais curiosas. Apresenta-se completamente como um espectador que bisbilhota o que se passa na cidade e na intimidade da família Stockmann, mas seu voyerismo esconde algo mais profundo: sua responsabilidade com relação à poluição. Algumas de suas especulações e zombarias ilustram tal ponto:

KIIL: it better be true or I'm going. (p.40) ${ }^{491}$

KIIL: Tom, I never thought you had the imagination to pull your own brother's leg like this. (p.41) ${ }^{492}$ KIIL: And nobody can see them [bacteria] but you, is that it? (p.41)

É justamente Kiil uma das personagens mais alienadas, que representam aqueles que estão no poder de forma indireta e que quando vêm seus interesses ameaçados, procuram manipular a situação para que o resultado Ihes seja conveniente. Um traço interessante sobre esta personagem é que Kiil coloca-se o tempo todo como uma pessoa que não possui culpa e/ou responsabilidade pela situação e que especula sobre a situação tentando desviar o foco para o âmbito pessoal.

\footnotetext{
${ }^{490}$ [MRS. STOCKMANN: Eu não sei, mas eu não gosto.]

${ }^{491}$ [KIIL: É melhor que seja verdade ou eu vou embora.]

492 [KIIL: Tom, eu nunca achei que você tivesse imaginação de passar a rasteira no seu irmão desse jeito.]

493 [KIIL: E ninguém consegue vê-las (as bactérias) a não ser você, certo?]
} 
Hovstad, assim como seus colegas de imprensa, incorpora o "espírito" daqueles que apoiaram voluntaria ou involuntariamente o macarthismo. Em dado momento, buscando livrar-se da culpa, tenta transferi-la a Billing:

HOVSTAD: I just want you to understand something: I never even read that book. It was Billing's idea. (p.69) ${ }^{494}$

Aqui novamente vemos o mecanismo do macarthismo em que para a pessoa se isentasse da responsabilidade, buscava jogar a culpa no outro. $O$ Sacrificial Scapegoating, tal como citado por Victor Navasky ${ }^{495}$, parte do pressuposto de que ao apontar os problemas dos outros o "acusado" é automaticamente absolvido dos seus. Miller procura desnudar os processos do macarthismo ao mostrar o embate entre personagens e a revelação de suas naturezas. O mecanismo de mesclar questões da ordem privada com a ordem pública é explicitado quando Peter ressalta acusações ao lado pessoal de Stockmann para em seguida estendê-lo ao coletivo:

PETER STOCKMANN, raising the manuscript and throwing it down on the table: This is based on vindictiveness, on his hatred of authority and nothing else. He pounds on the manuscript. This is the mad dream of a man who is trying to blow up our way of life! It has nothing to do with reform or science or anything else, but pure and simple destruction! And I intend to see to it that the people understand it exactly so! $(P .74-75)^{496}$

Este diálogo revela coisas importantes acerca do macarthismo: em primeiro lugar, a expressão 'Blow up our way of life' é justamente o que ameaçava os defensores do "red scare". A ameaça do comunismo colocava em risco o 'way of life' americano, ao qual a ideologia vigente se apegava e a

\footnotetext{
${ }^{494}$ [HOVSTAD: Eu só queria que você entendesse uma coisa: eu nunca nem li aquele livro. Foi ideia do Billing.]

${ }^{495}$ NAVASKY, Victor S. Naming Names. op.cit.

${ }^{496}$ [PETER STOCKMANN, levantando o manuscrito e jogando-o em cima da mesa: Isto é baseado em vingança, em seu ódio pela autoridade e nada mais. Ele bate no manuscrito. Este é o sonho louco de um homem que está tentando explodir o nosso modo de vida! Não tem nada a ver com a reforma ou a ciência ou qualquer outra coisa, mas a destruição pura e simples! E eu pretendo fazer com que as pessoas entendam exatamente assim!]
} 
possibilidade de subversão gerava o medo/paranoia da destruição do "bem-

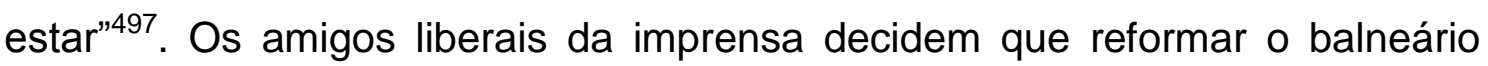
pode ser um erro, visto que isto requereria um esforço financeiro por parte de todos. A partir deste momento temos a grande tensão que a peça apresenta e que a caracterizará como tragédia liberal: o embate entre protagonista e as forças sociais.

\subsection{CONFRONTO PROTAGONISTA VERSUS FORÇAS SOCIAIS}

A grande tensão da peça é o embate entre o protagonista e as forças sociais que se opõem ferozmente a ele. É também este conflito que projetado na forma, confere à peça uma estrutura de tragédia liberal. O período da tragédia liberal, cujo início, segundo Williams, ocorre no século XIX, no período romântico, quando o homem descobre que vive em uma sociedade falsa e que toda sua energia e desejos individuais estão em contradição com essa sociedade. Raymond Williams explica que:

No centro da tragédia liberal há uma situação isolada: um homem no ponto culminante de seus poderes e no limite de suas forças, a um só tempo aspirando e sendo derrotado, liberando energias e sendo por elas mesmas destruído. A estrutura é liberal na ênfase sobre a individualidade que se excede, e trágica no reconhecimento final da derrota ou dos limites que se

impõem à vitória. ${ }^{498}$

A última fonte de tragédia liberal surgiria com lbsen, num momento em que o homem luta sozinho contra essa sociedade e é justamente em An Enemy que isto se materializa. Esta condição solitária e heroica do homem tem suas fontes na tragédia romântica e existencialista. À época do liberalismo

\footnotetext{
${ }^{497}$ Este sentimento de medo/paranoia de que o modo de vida da sociedade pudesse ser atacado e/ou destruído a qualquer momento encontra ilustração, por exemplo, no método de proteção que o governo ensinava contra os efeitos de uma explosão nuclear. O filme intitulado 'Duck and Cover' (1951), que era mostrado às crianças, apresentava 'Bert the Turtle' ensinando como sobreviver caso alguém ou o país fosse atacado.

${ }^{498}$ WILLIAMS, Raymond. op.cit., p.119.
} 
(romantismo) pediu-se ao homem que ele validasse seus instintos e que, de certa forma, negasse a política da sociedade, vista como destruidora. Todavia, quando o homem atingiu esse nível de consciência da capacidade de afirmar e superar seus limites, ele se deparou com a resistência da força que ele tanto negou: um sistema sócio-econômico-político que estorva a busca do homem livre e pleno. Já que ele faz parte desta sociedade, como nos lembra Williams, ele possui a "convicção da culpa", sendo conivente e responsável pelo estado de coisas:

E esse é o coração da tragédia liberal, porque passamos da posição heroica do libertador individual, do eu que deseja e que vai contra a sociedade, para uma posição trágica, do eu contra o eu. ${ }^{499}$

A procura do Dr. Stockmann por expor a verdade o condena à destruição e ao isolamento. Como já apontamos, Viviane Leme $^{500}$ em seu estudo nos diz que as tragédias millerianas possuem três elementos recorrentes: o primeiro deles é a defesa do nome e da honra, o segundo elemento é o destaque para a relação de causa e efeito (ressaltando, portanto, relações de conectividade e causação) e o terceiro é a justaposição das esferas pública e privada (aparentemente opostas), que por estarem contidas uma na outra, são facetas de uma única e mesma realidade. Stockmann, assim como aqueles que viveram o período do macarthismo, teve que enfrentar conservadorismo, inconstâncias e adesões gerais por parte da população à ideologia vidente.

$\mathrm{Na}$ primeira cena do primeiro ato encontramos algumas pistas sobre uma possível dissonância entre Peter e o Dr.Stockmann. Peter não aceita bebida, acha um absurdo comer carne a toda hora, trata Hovstad de maneira condescendente pelo fato de ele trabalhar para o jornal, etc. Já na segunda cena (ainda do primeiro ato), a personagem Aslaksen revela de maneira aberta

\footnotetext{
${ }^{499}$ Ibidem, p.136.

${ }^{500}$ LEME, Viviane. A concepção da tragédia moderna em The Crucible e A View from the Bridge de Arthur Miller. op.cit.
} 
sua posição conservadora, ou melhor, moderada (como ele mesmo coloca) já explicitando sua oposição em ir contra o poder vigente. Aslaksen, o Editor do jornal, define a si mesmo como Membro da 'Sociedade da Moderação', cidadão obediente às leis cujas influências na cidade podem ser chamadas de 'poder'. Um fato que chama bastante a atenção é que em uma das passagens temos a impressão de que Miller o apresenta como "filho" da geração de 1930, e do sentimento que caracterizou aquele período:

ASLAKSEN: (...) as a representative of the Temperance Society - you probably know, Doctor, that I am active for prohibition. (versão de Miller, p.47) (501 $^{2}$

No versão original do pai escandinavo do drama moderno, lê-se:

ASLAKSEN: No, thank you. I never drink alcohol of that kind.

(versão de lbsen, p.22) ${ }^{502}$

Chegamos à conclusão de que o termo "proibição" remete aos tempos

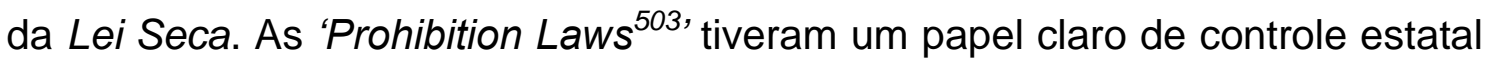
sobre os trabalhadores em geral a pretexto da proteção à família e à moralidade dos costumes, gerando uma contradição entre o discurso empregado (apoiado na tradicional moral calvinista norte-americana) e a função que ele teve historicamente. Miller mantém esta atitude de Aslaksen um pouco mais adiante quando Dr. Stockmann oferece um copo de cerveja a Aslaksen, que responde:

\footnotetext{
${ }^{501}$ [ASLAKSEN: (...) Como um representante da Sociedade Temperança - você provavelmente já sabe, doutor, que eu a favor da proibição.]

${ }^{502}$ IBSEN, Henrik. An Enemy of the People. op.cit. [ASLAKSEN: Não, obrigado. Eu nunca bebo álcool desse tipo.]

${ }^{503}$ Em seu livro Deliver Us from Evil (1976), Norman H. Clark documenta o impacto que os primeiros cristãos evangélicos tiveram em 'moderação' e 'proibição' no até então recém-fundado Estados Unidos. Clarke diz que Beecher, um jovem pregador evangélico nascido em 1775 “(...) reached his maturity with the conviction that his generation had fallen away from truth and morality during and immediately after the American Revolution and would have to be reformed in the spirit of the old orthodoxies".

[(...) alcançou sua maturidade com a convicção de que sua geração tinha se afastado da verdade e moralidade durante e imediatamente após a Revolução Americana e teria de ser reformada no espírito das velhas ortodoxias.]
} 
ASLAKSEN, considers, then: I don't think I can go quite that far, Doctor. I never take anything. (versão de Miller, p.48)

ASLAKSEN: (...) I never drink anything as early as this. (versão de Ibsen, p.22) $)^{505}$

$\mathrm{Na}$ realidade, Miller coloca na rubrica que a personagem 'considera', demostrando, portanto, hesitação. Logo depois, Aslaksen defende o respeito à autoridade para que elas não sejam machucadas:

ASLAKSEN: (...) I don't want any wild-eyed radicalism on this thing. I've had enough of that in my time, and no good ever comes of it. But for a good solid citizen to express his calm, frank, and free opinion is something nobody can deny. $(p .48)^{506}$

Peter segue confrontando Stockmann e seus ideais de maneira direta e distorcida, tentando convencê-lo, em vão, a largar a verdade. Em um momento mostra que sua análise leva em conta fatores pessoais e subjetivos, e não públicos e objetivos, dizendo:

PETER STOCKMANN: So you merrily conclude that we must build a wastedisposal plant - and reconstruct a brand-new water system from bottom up!

\footnotetext{
${ }^{504}$ [ASLAKSEN, considera, então: Eu não acho que posso ir assim tão longe, Doutor. Eu nunca bebo nada.]

${ }_{505}$ IBSEN, Henrik. An Enemy of the People. op.cit,. [(...) Eu nunca bebo nada assim tão cedo.]

${ }^{506}$ [ASLAKSEN: (...) Eu não quero qualquer radicalismo de olhos arregalados nesta coisa. Eu já aguentei o bastante disso no meu tempo, e nada de bom vem disso. Mas para um bom e firme cidadão expressar a sua calma, franca e livre opinião é algo que ninguém pode negar.]

${ }^{507}$ [PETER STOCKMANN: Então você alegremente conclui que nós devemos construir a planta de eliminação de resíduos - e reconstruir um sistema de água novo em folha de baixo para cima!]
} 
O termo 'merrily' apresenta a visão pessoal que Peter tem de seu irmão. Peter fala sobre o custo de 300.000 coroas e que a obra demoraria mais de dois anos. Além disso, não haveria um visitante sequer que iria a um lugar que outrora estivera infectado. Peter, enquanto homem de poder, analisa a situação e conclui que não está convencido de que as águas estejam poluídas. Esta relutância de Peter em admitir que haja de fato um perigo real, mesmo perante a evidência científica é algo que parece ser absurdo e inconcebível. Contudo, uma verdade inconveniente que precisa ser coberta a todo custo mesmo desautorizando um estudo científico não é algo incomum.

Em 2011 a mídia levantou questões sobre o fato de bebidas como a Coca-Cola e a Pepsi estarem fabricando bebidas cujas substâncias poderiam causar câncer. O estado da Califórnia incluiu naquele ano um componente químico na lista de substâncias cancerígenas. A associação das indústrias de bebidas dos EUA contestou o conteúdo do estudo: Embora acreditemos que não há risco para saúde pública que justifique mudanças, pedimos aos fornecedores do caramelo que deem esse passo para que nossos produtos não estejam sujeitos à exigência de um aviso sem fundamento científico ${ }^{508}$, afirmou a representante da Coca-Cola, Diana Garza Ciarlante. Em suma, a possibilidade de causar câncer é subestimada, pois o número real de ingestão do produto para que se chegue ao câncer deve ser alto. Somente em uma sociedade desprovida de princípios éticos, é possível ver-se a banalização de algo nocivo à saúde em nome do lucro. O artigo é concluído com a seguinte declaração da empresa:

"O corante caramelo utilizado em nossos produtos é absolutamente seguro. Coca-Cola não alterará sua fórmula mundialmente conhecida. Mudanças no processo de fabricação de qualquer um dos ingredientes, como o corante caramelo, não tem potencial para modificar a cor ou o sabor da Coca-Cola", disse a empresa em nota. A pergunta que permanece é: a possibilidade da existência de uma substância cancerígena não deveria ser alarmante e ser

\footnotetext{
${ }^{508}$ Artigo online publicado na Folha de São Paulo, no dia 09/03/2012, sob o título de: Coca e Pepsi mudam fórmula para evitar alerta de câncer nos EUA. (http://www1.folha.uol.com.br/mercado/1059463coca-e-pepsi-mudam-formula-para-evitar-alerta-de-cancer-nos-eua.shtml). Acesso na mesma data de publicação.
} 
solucionada o quanto antes (independente de as chances serem altas ou baixas)?

Retornando a An Enemy, Peter reclama que qualquer ideia que surja em sua cabeça por mais idiota que seja, se torna tema de um panfleto a ser escrito. Quando Dr. Stockmann contra argumenta perguntando a Peter se ele não acha que é dever de um cidadão dividir suas ideias com o público, Peter responde:

PETER STOCKMANN: The public doesn't need new ideas - the public is much better off with old ideas. $(p .55)^{509}$

Esta fala representa justamente a mentalidade do macarthismo em que qualquer ideia nova era, portanto, subversiva. A manutenção de um sistema com ideias já estabelecidas garantiria, na retórica paranoica anticomunista dos anos 1950, um sistema mais unido e menos ameaçador. Peter é adepto da manutenção do status quo e da filosofia do "panis et circenses'510. Prossegue dizendo que Dr. Stockmann está sempre combatendo autoridades e quando recebe uma ordem acha que está sendo perseguido.

$\mathrm{Na}$ primeira cena do segundo ato, há um momento em que Dr. Stockmann vê o chapéu e a bengala de seu irmão e descobre que há algo de errado acontecendo. Hovstad permanece imóvel o tempo todo (assim como muitos o fizeram durante o macarthismo) e Aslaksen pede calma. Dr. Stockmann procurará defender a si e a suas ideias, mas o que se segue é uma série de retaliações que desviam uma questão de ordem pública para o lado pessoal. Atacando a moral de Dr. Stockmann e transformando-o em uma personagem motivada pelo desejo de vingança (em relação à autoridade,

\footnotetext{
${ }^{509}$ [PETER STOCKMANN: O público não precisa de ideias novas - o público está muito melhor com as ideias antigas.]

${ }^{510}$ A expressão 'Pão e Circo', originalmente 'Panem et Circenses' em Latim, refletia a maneira como os líderes romanos lidavam com a população em geral com o intuito de mantê-la fiel à ordem estabelecida excluindo a reflexão de tal processo. Comida e diversão tornaram-se os "ingredientes" perfeitos para a manutenção e aceitação do status quo.
} 
materializada na figura de seu irmão) e de ataque ao bem-estar do povo, Stockmann torna-se um inimigo do povo.

\section{CAPÍTULO III - CONSIDERAÇÕES FINAIS ACERCA DAS DUAS PEÇAS}

A pesquisa concentrou-se na análise formal de duas peças fundamentalmente importantes de/para Arthur Miller: All My Sons, que o consagra como dramaturgo talentoso e An Enemy of the People, que inaugura sua ofensiva contra o macarthismo. A escolha de ambas as peças como objeto de análise desta dissertação levou em conta que em ambas há um denominador comum: Henrik Ibsen. O status que Miller alcança com All My Sons em 1947 tem seu triunfo, segundo a maioria dos críticos literários, pela forte temática do pós-guerra que se vê entrelaçada à concepção aristotélica dos laços de família, o que potencializa o efeito trágico (segundo esses críticos). De maneira similiar, atribui-se algum valor ${ }^{511}$ a An Enemy of the People (de 1950) por ter sido escrita pelo pai do drama moderno, lbsen, e por ter sido corajosamente adaptada no período do macarthismo. As críticas correntes também ressaltam que a força da peça recai sobre como ocorre a destruição de uma família (a de Stockmann) devido aos interesses de quem está no poder.

Nosso ponto de partida na pesquisa foi o de que a forma cumpre um papel que frequentemente não é enxergado. Miller recorre ao norueguês não somente pela questão dos temas fortes, como apontam os renomados críticos literários, mas pela questão da forma: em ambas temos a tragédia, que visa restaurar relações de causa e efeito, ressaltando a dimensão social (pública) de erros e desmandos do âmbito privado. Na relação dialética entre forma e conteúdo verificamos que Miller consegue, ao mostrar o homem em sua subjetividade e sua vida social, elucidar o funcionamento da sociedade em

\footnotetext{
${ }^{511}$ Colocamos como "algum valor" porque a peça, como já demonstramos, é frequentemente negligenciada (quando não, esquecida) e é criticada por ser uma peça de tese, com um enredo inverossímil.
} 
termos de sua dinâmica, apontando sua estrutura, sua dialética e sua evolução. Assim sendo, mapeamos como o conteúdo e forma estão dialeticamente ligados, entendendo de que maneira o pós-guerra (em All My Sons) e o macarthismo (em An Enemy) foram transpostos para o palco. O avanço formal das peças está no fato de que elas não se restringem ao arcabouço formal que a peça bem feita e que a tragédia propiciam. Ao contrário, incorporam outros elementos que enriquecem a estrutura de ambas e que propõem uma crítica contundente à sociedade americana (levando em conta o caráter histórico) e a própria essência humana.

All My Sons apresenta uma tensão formal entre o conteúdo (o passado) e a forma (drama), que tradicionalmente só permite que o presente seja dramatizado. Ao mesmo tempo em que Miller se utilizou dos preceitos aristotélicos de tempo, lugar e ação (o que o aproximou da concepção grega de tragédia) também $\mathrm{o}$ afastou em alguns pontos incorporando elementos da tragédia moderna. Utilizando-se da estrutura de peça bem feita, ao inserir a técnica analítica de Ibsen, Miller não somente se consagrou como um dos dramaturgos mais importantes da América, como também trouxe uma outra perspectiva para o que estava sendo colocado em sua "tragédia analítica". Miller (e a técnica ibseniana) evocam o passado através da rememoração e a ação presente se torna a análise do passado. Diferentemente de Édipo, em que o público já conhecia o mito e o passado era revelado somente a ele próprio, em All My Sons, o passado é revelado ao público ${ }^{512}$. Como já mencionamos anteriormente, Hogan comenta a técnica analítica, dizendo:

Esta estrutura é de difícil manejo, pois o teatrólogo precisa mais explicar do que dramatizar grande parte da ação, e o peso da exposição sempre ameaça dissolver o impacto dramático da peça. Há provavelmente três maneiras principais de combater tal ameaça: pela beleza evocativa do diálogo, pela ironia e por uma hábil mistura da ação atual com explicação da ação passada. ${ }^{513}$

\footnotetext{
${ }^{512}$ É preciso frisar que o passado não era revelado pura e simplesmente, mas submetido à análise.

${ }^{513}$ HOGAN, Robert. Arthur Miller. op.cit., p.31-2.
} 
Acreditamos que o impacto dramático da peça não é, de forma alguma, dissolvido pelo peso da exposição do passado, ao contrário do que afirma Hogan (como já citado anteriormente). O uso da estrutura de peça bem feita, acaba garantindo até os minutos finais, que haja impacto. Um exemplo curioso é a carta que Ann revela à família (que é um recurso bastante condenado pelos críticos em geral por parecer inverossímil), e que auxilia uma das últimas peças do quebra-cabeça a ser encaixada. Assim sendo, a técnica de trazer o passado à tona por meio da rememoração dialoga dialeticamente com o conteúdo engendrado nela, que é o passado e suas consequências. Além disso, a estrutura de peça bem feita usada por Miller, assim como a usada por Ibsen em diversas de suas peças, traz discussão e reflexão o que não a torna inferior, segundo nos lembra Shaw.

An Enemy of the People faz uso da forma da tragédia liberal, cuja marca principal é mostrar e discutir a luta do homem contra a sociedade. Na tragédia liberal, Raymond Williams nos diz, (...) há uma situação isolada: um homem no ponto culminante de seus poderes e no limite de suas forças, a um só tempo aspirando e sendo derrotado, liberando energias e sendo por elas mesmas destruído. A estrutura é liberal na ênfase sobre a individualidade que se excede, e trágica no reconhecimento final da derrota ou dos limites que se impõem à vitória ${ }^{514}$.

Desta maneira, a peça, que também se utiliza da estrutura da peça bem feita, avança formalmente por resgatar elementos da tragédia grega (apontando para o fato de que os homens são responsáveis pelo que acontece na sociedade) e por resgatar da tragédia liberal a dialética engendrada no conflito entre desejo individual e os limites impostos pela sociedade à realização deste (o que trará a situação paradoxal do indivíduo que precisa se destruir para se preservar).

Ressaltamos durante a pesquisa que há três elementos que sustentam a dramaturgia milleriana e que estruturam praticamente todas as suas peças, sendo eles: a defesa do nome e da honra, a relação entre causa e efeito e a 
justaposição das esferas privada e coletiva. Esses elementos recorrentes na dramaturgia de Miller funcionam como ferramentas que auxiliam o ajuste de "peças" que se encontram desajustadas ou dispersas.

Com relação ao enredo, All My Sons e An Enemy possuem a linha de tensão ascensional (estruturada em introdução, complicação, clímax e desfecho) que garante o nexo causal, fazendo com que cada ação tenha uma motivação. Miller estrutura as duas peças em três atos, que se encaixam ainda no modelo ascensional preconizado pela peça bem feita, sendo que An Enemy tem originalmente cinco $^{515}$. Segundo os gregos, tal organização do enredo permitiria o objetivo final da tragédia: a purificação das emoções. Entretanto, Miller visou não somente as emoções, como afirma em seu ensaio The Nature of Tragedy, de 1949:

Tragedy brings us not only sadness, sympathy, identification and even fear; it also, unlike pathos, brings us knowledge. ${ }^{516}$

Miller acredita que o palco é o lugar das ideias e defende o direito do dramaturgo de entreter não somente com emoções, mas, com o cérebro. Isso o alinha a outros dramaturgos de calibre como Shaw, Ibsen, Tchekhov, Strindberg etc. Para que o conhecimento seja atingido, Miller desviou-se da noção do destino e colocou nas próprias personagens a responsabilidade pela situação atual. A técnica analítica de All My Sons traz o passado à tona como um raio certeiro que atinge o palco sem deixar dúvidas de que as ações individuais se estenderam ao todo e em An Enemy of the People a manipulação dos que estão no poder leva Dr. Stockmann à ruína e seu desejo torna-se sua própria destruição.

Com relação ao tempo, All My Sons se passa em um período de vinte e quatro horas, o que lembra a noção grega, dentro da qual acreditava-se que extrapolar esse período pudesse parecer inverossímil. Já em An Enemy, Miller

\footnotetext{
515 Como mencionamos, segundo FREYTAG (1863), a questão do número de atos está mais ligada à questão da troca de cenários e figurinos do que à estrutura propriamente dita. Portanto, a alteração feita por Miller não afeta a estrutura, pois o primeiro e último atos são respectivamente introdução e desfecho, enquanto o segundo foca no desenvolvimento da ação.

${ }_{516}$ MILLER, Arthur. The Nature of Tragedy. op.cit., p.9. [A Tragédia nos traz não somente tristeza, simpatia, identificação e mesmo medo; ela também, ao contrário de pathos, nos traz conhecimento.]
} 
(e lbsen) não se ativeram à questão do tempo, o que se justifica nas palavras de Roudine:

(...) o aristotelismo se mostra impotente para pensar a convenção temporal com a qual o teatro joga livremente..$^{517}$

Assim sendo, a forma escolhida por Miller (e lbsen) quebra com a convenção aristotélica e consegue manter a verossimilhança e possui um poder elucidador ao mostrar a justaposição das esferas individual e coletiva. Com relação às personagens, tanto em All My Sons quanto em An Enemy pudemos ver que Miller não as constrói de maneira maniqueísta. As personagens não são totalmente boas ou ruins, havendo em praticamente todas elas o potencial para ambos. Há as que participam diretamente com escolhas e as que participam também ao não escolher. Há as que não compactuam com um sistema fraudulento e injusto (George ${ }^{518}$, Dr.Stockmann e Petra), aquelas que agem diretamente (Joe Keller, Peter Stockmann, Hovstad, Billing, Aslaksen) e ainda há aquelas que clamam por inocência e buscam se manter "neutras" (Kate Keller, os vizinhos de All My Sons, Morten Kiil). Desta forma, confirma-se um dos pressupostos da dramaturgia milleriana de que não há inocentes, portanto, clamar por inocência é um erro brutal que necessariamente conduzirá à queda. As personagens trazem em si contradições e ambiguidades que são próprias da essência humana e que estão estampadas na discrepância entre o que as personagens são e aquilo que elas gostariam de ser. Joe Keller é um criminoso, mas não se enxerga e nem se apresenta como tal; Kate sabe que foi conivente com o crime do próprio filho; Ann se vende ao desejo de casar prometendo fazer silêncio em relação a denunciar Keller e manter seu próprio pai preso; os vizinhos sabem do que se passa ao redor, mas compactuam com a mentira. Tudo converge para a noção de que a consciência é algo que precisa ser alcançado e do qual não se pode escapar. Aliás, é a negligência para com ela que ineroravelmente

\footnotetext{
${ }^{517}$ ROUDINE, Jean-Jacques. Introdução às grandes teorias do teatro. op.cit., p.43.

${ }^{518}$ A personagem George não compactua até certo ponto, pois não hesitou em questionar o fato de que seu pai havia sido incriminado e ele mesmo confessa ter acreditado na versão aparente porque Chris assim o fizera.
} 
repercutirá em outras esferas e atesta uma frase importante de Miller em relação à estrutura de suas peças e que dialoga diretamente com o conteúdo engendrado nela:

The structure of a play is always the story of how the birds came home to roost. $^{519}$

Os erros e negligências do passado certamente voltarão e clamarão que alguém se responsabilize por isso, seja para que haja o reconhecimento e portanto, o efeito trágico da queda (caso de Joe Keller), ou seja pela manutenção do status quo (caso de Stockmann, que é responsabilizado pelos erros e desmandos da má administração de Peter).

Em An Enemy, as personagens também apresentam a capacidade de se submeter aos ditames do momento e até os instantes finais vemos como as personagens (e as pessoas que estiveram envolvidas no macarthismo, pensando analogamente) venderam suas consciências em prol de interesses próprios. Os rapazes da imprensa, Hovstad, Aslaksen e Billing, inicialmente apoiam Dr.Stockmann, depois o demonizam, e em seguida tentam novamente apoiá-lo segundo novas condições (pagar as despesas de impressão do jornal) para no fim não apoiá-lo novamente. O Dr. Stockmann de Miller, ao contrário do de lbsen, se mostra um pouco menos idealista e mais centrado. Como já apontamos na análise, a mudança que Miller fez na fala de que "a minoria está sempre certa" para: "a maioria está sempre certa, até que faça o certo", escancara a inegável presença de Arthur Miller, que sempre foi muito consciente de que é preciso agir para que se defina o caráter (algo que ficou bastante claro em sua crítica ao macarthismo).

As rubricas que analisamos nos trouxeram grande compreensão com relação a um contexto maior impregnado nas peças. Em All My Sons, as rubricas evidenciaram de maneira escancarada a força do passado e sua tendência a penetrar no presente. Algumas delas ocuparam-se em descrever

\footnotetext{
${ }^{519}$ MILLER, Arthur. [A estrutura de uma peça é sempre a história de como os pássaros voltam para a casa para aninharem-se].
} 
as personagens para que fossem compreendidas em maior amplitude e outras indicavam as ações não-verbais que paradoxalmente falavam muito mais do que 0 falatório trivial que se proferia constantemente ${ }^{520}$. Salientamos que a peça inclusive termina com uma rubrica (que aponta os soluços de Kate como o último ato não-verbal da peça) e não deixa que o passado seja sufocado, sendo eles (os soluços) a expressão de que o passado estava fincado categoricamente no presente. Em An Enemy, Miller utiliza as rubricas para em grande medida situar as personagens dentro da dramaturgia ibseniana ao aprofundar a descrição sobre as personagens. Tal recurso reforça a essência Ibseniana da peça de que certas personagens como Petra, Capitão Horster e Stockmann não se deixam vender pelas pressões e embates entre interesses públicos e privados, enquanto que a que descreve Morten Kiil, já o coloca como alguém que age sorrateiramente. As rubricas, portanto, auxiliam, assim como em All My Sons, o entendimento de que as ações das personagens não estão/são desligadas de um contexto.

Ambas as peças resgatam a consciência e a responsabilidade. Aliás, ambas servirão como solo fértil para Death of a Salesman, The Crucible, After the Fall etc, incorporando inovações formais, tais como técnicas expressionistas e recursos épicos.

O caminho percorrido através desta pesquisa mostrou que ambas possuem um potencial extraordinário de simultânea denúncia social e de avanço dramatúrgico. A genialidade da escolha de Miller em utilizar a tragédia para tratar dos assuntos figurados nas peças é de grande valia para os estudos de teatro, de história, de cultura, de política e de cidadania. Um dos pontos mais importantes que o ganhador do Pulitzer resgata da tragédia não é a noção de destino e sua força (como viam os gregos), nem uma força metafísica (como viam os clássicos). O que se resgata é o sentido de causação, dentro do qual as causas se conectam aos efeitos, estabelecendo uma compreensão do tempo com mais amplitude e coerência. A esfera pública e a privada se mostram como faces de uma mesma moeda que, estampadas com os rótulos de 'consciência' e 'responsabilidade', religam o senso de coletividade ofuscado

\footnotetext{
${ }^{520}$ Fato este que é magistralmente manejado por Anton Tchekhov (principalmente) e August Strindberg.
} 
(quando não, afogado) em tempos atuais. Este senso perdido paradoxalmente é retratado em dois momentos históricos importantes e marcantes para os Estados Unidos: o período do pós-guerra e o macarthismo, que pareciam momentos em que a sociedade estava unida em prol de uma ideologia comum. Entretanto, ambas as peças surgem como maneira de mostrar em que solo está sustentada tal união.

O grande triunfo de Miller é que ele se mostrou cauteloso em não concentrar sua crítica em um único indivíduo ou em uma única instituição, e que procurou demonstrar a rede de conexões em que este indivíduo está envolvido e o qual ele influencia e é influenciado. Em All My Sons, por mais que Joe Keller quisesse culpar a sociedade, Chris o faz enxergar voluntaria ou involuntariamente que ele era, de fato, responsável pelo estado de coisas, descartando qualquer alegação em ter feito o que o período da guerra exigia ou mesmo tentando utilizar a astrologia como fator determinante do destino desde o nascimento ${ }^{521}$. Em An Enemy, Stockmann poderia ter concentrado sua crítica naqueles que estavam no poder (minoria), mas, opta por criticar duramente a maioria (que por sua vez é gerenciada pela minoria). É preciso, portanto, ver o que está além do aparente, algo que segundo Miller, temos dificuldade em fazer:

This evident inability [of the Americans] to see a context behind an action does not stop at Politics. I think it is part of our method of seeing life. Our critics will be inclined to see the hero of a play as a psychological figure, as an individual, a special case always, and their interest flags beyond that point. It is even said that, strictly speaking, it is not their business as to the larger significance of a character portrayed on the stage. ${ }^{522}$

\footnotetext{
${ }^{521}$ Algo de relevância extrema que precisa ser mencionado é que em determinado ponto da peça, Kate diz que "tudo está escrito já desde que nascemos" e vale relembrar também que Miller planejava chamar a peça de "The Sign of the Archer", em alusão à dimensão astrológica que estampa a "tentação da inocência" tão presente na dramaturgia milleriana.

${ }^{522}$ MILLER, Arthur. "1956 and All This”, publicado em 1956 em Colorado Quarterly 5, sob o título de 'The Playwright and the Atomic Bomb' e republicado em Tulane Drama Review, em Junho de 1961 sob o mesmo título. In: MARTIN, Robert A; CENTOLA, Steve R. (ed), op.cit., p.95. [Esta evidente inabilidade (dos americanos) de enxergar um contexto por detrás das ações não para na política. Acho que é parte do nosso método de ver a vida. Nossos críticos estarão inclinados a ver o herói de uma peça como uma figura psicológica, como um indivíduo, um caso à parte sempre, eles não se interessam por questões além desse ponto. Até mesmo se diz que, estritamente falando, não é da conta deles saber quanto às significações mais amplas de uma personagem representada no palco.]
} 
Miller lança perguntas à história, à consciência, à liberdade e à política. O percurso analítico é tão tentador que cada "peça do quebra cabeça" merece ser analisada, mas atemo-nos a não concluir e nem esgotar a análise, buscando entender como o estudo da forma das duas peças revela o que há de mais profundo em Miller (e também em lbsen) não somente no que é manifesto, mas, naquilo que está latente. O contexto por trás (e dentro) das peças, nos faz enxergar com magnitude o que está além do aparente. Assim sendo, as peças de Arthur Miller em grande medida ressuscitam as esperanças de que nem tudo está perdido. Corroborando uma frase importante de seu ensaio, o dramaturgo considerado 'Un-American' nos diz que na tragédia vemos não somente o sofrimento do homem, mas também vemos como ele poderia ter evitado seu fim sofredor. ${ }^{523}$ Desta forma, encontrar bodes espiatórios sob a insígnia de capitalismo, religião, comunismo, política, lei etc, deverá necessariamente passar pelo crivo da consciência e da escolha individuais.

Enfatizando a responsabilidade e elucidando a importância da consciência, Miller parece trazer a realidade de volta àqueles que deliram com a possibilidade de manter atos antiéticos impunes. $O$ dramaturgo altamente Ibseniano (que aliás traz um Ibsen reformulado aos Estados Unidos com ambas as peças) nos faz lembrar das palavras que Shakespeare colocara na boca de Cassius, personagem de sua peça "Julius Caesar":

The fault, dear Brutus, is not in our stars

But in ourselves, that we are underlings. ${ }^{524}$

\footnotetext{
${ }^{523}$ MILLER, Arthur. The Nature of Tragedy. In: MARTIN, Robert A; CENTOLA, Steven R, op.cit, p.11. ${ }^{524}$ SHAKESPEARE, William. Julius Caesar, Ato I, Cena II. [A culpa, caro Brutus, não está nas nossas estrelas, mas em nós mesmos, que somos subordinados.]
} 


\section{ANEXOS A e B}

\section{ANEXO A \\ Arthur Miller: banido dos palcos e aceito na sala de aula.}

Na cidade de Fulton, Missouri, uma professora de teatro da Fulton High School, Wendy DeVore, decide trabalhar com seus alunos o musical 'Grease', que fala sobre alunos do Ensino Médio nos anos 1950. Tal decisão foi o início de um debate que incendiou não somente a cidade em questão, mas a reflexão acerca da própria função da arte.

Membros da Associação Cristã de Callaway enviaram reclamações de cenas em que adolescentes bebem, fumam e se beijam no palco, indo, portanto, longe demais. A professora precisou retrabalhar cuidadosamente a linguagem da peça para que as pessoas não se sentissem ofendidas. Dr. Mark Enderle, superintendente da escola, decidiu então evitar que o mesmo se repetisse com a próxima peça que estava programada para a primavera seguinte: 'The Crucible', de Arthur Miller.

Sob a desculpa de que o retrato excessivamente político e histórico de Arthur Miller pudesse trazer problemas à escola, Diana Jean Schemo (repórter do New York Times), esclarece a atitude preventiva do superintendente:

He called "The Crucible" "a fine play," but said he dropped it to keep the school from being "mired in controversy" all spring.

\footnotetext{
${ }^{525}$ http://www.nytimes.com/2006/02/11/national/11fulton.html?pagewanted=all\& $r=0$ [Ele chamou 'As Bruxas de Salém' 'uma ótima peça', mas disse tê-la abandonado para impedir que
} 
Tal controvérsia é algo que não pode ser facilmente entendido visto que, de acordo com a "Educational Theater Association":

"Grease" and "The Crucible" are hardly unfamiliar; they are standard fare on the high school drama circuit, the second-most-frequently-performed musical and drama on school stages, according to the Educational Theater Association, a nonprofit group. The most performed now are "Seussical" and "A Midsummer

Night's Dream"526.

O fato de que ambas são peças encenadas frequentemente e são parte do currículo escolar de alunos nos Estados Unidos, nos faz estranhar tal atitude. $O$ superintendente decidiu fazer uma enquete e perguntou a dez pessoas se elas achavam que 'The Crucible' ultrapassava os limites. Todos, exceto um, disseram que sim:

Dr. Enderle said he dropped the play after seeing this summary on the Web: "17th century Salem woman accuses an ex-lover's wife of witchery in an adaptation of the Arthur Miller play. (...) Mr. Miller wrote "The Crucible" in the 1950 's, in response to the witch hunt of his own day, when Congress held hearings to purge Hollywood of suspected Communists, pressuring witnesses to expose others to prove their innocence. The affair is not acted out in the play, which focuses on how hysteria and fear devoured Salem, despite the lack of evidence. ${ }^{527}$

a escola ficasse "atolada em controvérsias" durante toda a primavera. - Acesso em $10 / 07 / 2013$.

526 ["Grease" e "As Bruxas de Salém" são dificilmente desconhecidas, pois elas são padrão no circuito de drama do ensino médio, e estão em segundo lugar como musical e drama mais frequentemente encenados nos palcos escolares, de acordo com a 'Associação Educacional de Teatro', um grupo sem fins lucrativos. As mais executadas agora são "Seussical", de Lynn Ahrens e Stephen Flaherty e "Sonho de Uma Noite de Verão", de William Shakespeare.] Os dados supracitados referem-se ao ano de 2006, entretanto, segundo a Associação, as peças mais encenadas em escolas em 2013 foram: (Musical: A Bela e a Fera e Legalmente Loira; Drama: 'Almost, Maine', de John Cariani e 'Sonho de Uma Noite de Verão', de William Shakespeare.) Atrás dessas duas no gênero drama estão: 'Our Town'(Nossa Cidade), de Thornton Wilder e 'You can't take it with you', de Kaufman e Hart. Fonte:

http://schooltheatre.org/PlaySurvey (Associação Educacional de Teatro)

${ }_{527}$ [Dr. Enderle disse que desistira da peça após ver este resumo na internet: "Mulher de Salém do Século 17 acusa a esposa de um ex-amante de bruxaria em uma adaptação de Arthur Miller (...) O Sr. Miller 
Se 'The Crucible' elenca uma das peças mais encenadas nas escolas americanas e é parte quase que obrigatória no currículo dos alunos, o superintendente não completou seus próprios estudos? O que nos chama a atenção de antemão na fala do Dr. Enderle é que ele, ao invés de ler a peça, preferiu ler um resumo na internet, mostrando total desconhecimento de um dos cânones do teatro norte-americano. Além disso, em sua fala enxergamos um espelho do que as críticas literárias e não-literárias hegemônicas nacionais e internacionais normalmente priorizam: o foco na esfera individual e psicológica (mulher acusa a esposa de um ex-amante de bruxaria) e redução de sua importância em referência a uma peça ultrapassada e/ou datada (Miller escreveu sobre a caça às bruxas de seu próprio tempo). Em primeiro lugar, 0 fato de a mulher (Abigail) acusar a esposa de seu ex-amante (Elizabeth Proctor) de bruxaria, não constitui o enredo da peça, mas uma consequência direta da maquinaria do denuncismo incentivado durante o macarthismo. O que importa se pensar é o que está por trás (e dentro) desta sociedade que usa a bruxaria como um elemento de manipulação social e não somente como vingança pessoal. Em segundo lugar, ao contrário do que diz Dr. Enderle, Miller não escreve 'The Crucible' como resposta à caça às bruxas de seu tempo, mas do tempo de toda a nação americana, tempo este que não cessa, mas se traveste de outros nomes, como 'ato patriótico', 'nacionalismo', 'segurança nacional' etc e que se estende até hoje. Dr. Enderle inclusive parece querer desqualificar o valor documental e histórico da peça ao dizer que a histeria e o medo não puderam ser provados. O que é no mínimo curioso observar é que o superintendente se empenha em justificar uma inferioridade na peça, mas apesar de ter cancelado a temporada de 'The Crucible', afirmou não estar completamente confortável com a decisão. Em outras palavras, ele fez o que "deveria" ser feito, cedendo à pressão daqueles que se sentiram incomodados e/ou ameaçados. Sua atitude, que lembra a de Hovstad (de 'An Enemy') que pretende publicar somente aquilo que os assinantes do jornal querem ler, se opõe radicalmente à crítica máxima de Miller: a questão de pessoas 
submeterem suas consciências para um momento específico. A atitude do superintendente lembra também, em todos os sentidos, uma das falas de Dr. Stockmann quando este compara uma atitude complacente ao gosto da maioria (ou de uma minoria que está no poder?), com o "naufrágio da civilização" que carregaria como mensagem: "Eles não ousaram".

Dr. Enderle parece não saber que a educação não precisa evitar controvérsias, mas sim explorá-las e refletir sobre tal natureza e pior ainda: deve desconhecer o fato histórico de que as peças de Shakespeare também foram alvos da proibição dos puritanos que a baniram, sob o pretexto de que imoralidade e maus hábitos não deveriam ser representados. Tal posição nos faz refletir sobre o recrudescimento do conservadorismo, mesmo em face às questões históricas e sociais colocadas constantemente diante dos olhos dos americanos. Parece-nos que a solução mais plauzível encontrada pela cidade foi a de manter a postura da tradição puritana: proibir. Aliás, 'vigiar' e 'punir' seriam duas palavras bem adequadas para o que está engendrado no aparentemente inocente "proibir". Fulton, uma cidade conservadora de mais ou menos 10.000 habitantes, é uma cidade em que pequenas objeções podem levar a mudanças nas fronteiras culturais de uma cidade inteira. A cidade, que é adepta dessa prática antiga e favorita da ética(?) puritana da proibição, é conhecida como lar da 'Faculdade de Westminster', na qual Winston Churchill deu seu discurso da cortina de ferro em 1946.

A necessidade de um debate público reafirma o poder revolucionário e de cidadania que a literatura traz em seu bojo. O que se testemunhou na Universidade de São Paulo, em Novembro de 2013, pode ser chamado de a contraparte do que acontecera em Fulton High ${ }^{528}$, em 2006.

\footnotetext{
${ }^{528}$ Esta questão do veto a 'Grease'e 'The Crucible'é explorada no documentário 'Small Town Culture War', de Amy Mack. Um fato curioso é que o documentário foi retirado de circulação e encontra-se misteriosamente "indisponível". Poderíamos entender que o estoque das mídias de DVDs pode ter esgotado e não há interesse por parte da produtora em relançar o documentário em questão. Entretanto, a Amazon, que disponibiliza praticamente todos os seus filmes e documentários em versão online sob a categoria de 'Instant Video', também diz que o documentário em questão está “indisponível”. Também não se encontram DVDs usados ou seminovos para serem assistidos.
} 
Em ocasião de um curso de língua inglesa ${ }^{529}$ no qual tenho o costume de inserir livros a serem lidos todos os semestres, decidi que meus alunos ${ }^{530} \mathrm{de}$ Upper Intermediate II (Intermediário Superior II) leríam 'All My Sons', de Arthur Miller.

A experiência da leitura e debate em sala de aula foi extremamente profícua e mostrou o quão grande é o talento de Miller em colocar no papel aquilo que pensa e de tirar do papel o que há de mais importante e levar à mente e ao coração das pessoas ${ }^{531}$. Os alunos estavam munidos da peça escrita; de uma versão em áudio da peça encenada em 1974 e publicada pela $L A$ Theatre Works; de uma versão filmada em 2010 em Londres, sob direção de Howard Davies, comercializada pela Digital Theatre, e foram assistir ao filme 'Hannah Arendt' que coincidentemente entrou em cartaz nos cinemas de São Paulo. A discussão rendeu duas aulas consecutivas nas quais o entusiasmo e envolvimento dos alunos eram inegáveis. Uma das alunas relata o seguinte:

Quando iniciei essa atividade, pouco conhecia de Arthur Miller. Sabia que ele era casado com Marilyn Monroe e que tinha escrito 'A Morte do Caixeiro Viajante'. Com esse nível de conhecimento comecei a ler 'All My Sons'. Gostei logo de início. Riscava as palavras que tinha dúvidas e fui tomando contato com as personagens e suas questões. O segundo momento foi "ouvir" o livro relendo-o. Nesse meio tempo, nas nossas pausas para o café no final das aulas, comentávamos com os colegas nossas impressões e enriquecíamos com nossas trocas. (Grifo meu)

O entusiasmo e envolvimento são explícitos na fala da aluna que relatou ter retirado Arthur Miller do contexto da sala de aula e o trazido para discussão em um contexto fora da aula. $\mathrm{O}$ fato de que a leitura suscitou discussões e trocas

\footnotetext{
${ }^{529}$ Curso semestral oferecido pelo Centro de Línguas da Universidade de São Paulo, no qual leciono.

${ }^{530}$ Os alunos da turma variam em faixa etária de 26 a 70 anos, sendo que a maioria tem idade de 40 em diante, e todos possuem grau superior completo, com exceção de uma aluna, a de 26 anos, que está na graduação em Letras (Espanhol).

${ }^{531}$ Com o êxito da discussão e do envolvimento dos alunos com o projeto, solicitei que ao final eles fizessem um breve relato sobre a experiência de ter trabalhado com o texto de Arthur Miller dentro da sala de aula. Deixei que eles estivessem livres para escrever em inglês ou português e, com a autorização de todos eles, reproduzo aqui algumas partes dos relatos. Optei por transcrevê-las já diretamente para o português, fazendo as devidas correções ortográficas e gramaticais quando necessário.
} 
que contribuíram para o enriquecimento dos alunos só evidencia mais ainda que Miller estava certo ao dizer que o dramaturgo deve entreter com seu cérebro, assim como com seu coraçãa ${ }^{532}$.

Um dos resultados mais interessantes envolvidos neste processo foi a percepção do caráter universal da peça que consagrou Miller como um dos maiores dramaturgos do Século 20. Ao contrário do que afirmam diversos críticos do mundo todo, o pano de fundo de All My Sons (a momento do pósguerra), nada tem de datado. É justamente o que emana dele que consegue atingir o cerne da crítica ao lucro desenfreado, à ganância e à falta de consciência social. O mais gratificante em relação à leitura feita pelos alunos é que o contexto sócio-histórico da peça se sobrepôs à percepção majoritária dos aspectos autobiográficos e psicologizantes. Além disso, algo que chamou a atenção foi o fato de que a forma parece ter cumprido uma função relevante em relação à leitura que se fez em aula. Uma outra aluna diz o seguinte:

O passado confrontado com o presente e na forma como foi feito, com temas de negação, culpa, responsabilidade, idealismo, chamou a minha atenção.

(Grifo meu)

A aluna em questão relatara sobre o fato de que a forma continha em si os conteúdos e temas que Ihe chamaram a atenção. A forma de 'All My Sons', que se caracteriza fortemente pela presença da 'técnica analítica' de Ibsen, foi algo que chamou atenção também de um outro aluno:

Em um primeiro momento eu achei que a história fosse sobre a vida no interior, onde as pessoas viviam em paz, falando sobre o tempo, sobre a natureza, as árvores, pássaros, felicidade e tudo isso com um casal no centro da família (...).

As conversas de alguma forma eram sempre em referência ao passado, e 0 passado era um tipo de assunto que ninguém falava diretamente, mas todos se baseavam nele para falar.

${ }^{532}$ MILLER, Arthur. An Enemy of the People. New York, Penguin Books, 1979, prefácio. 
O passado é, então, percebido como o próprio assunto da peça (típico da peça analítica) e a dialética entre forma e conteúdo se mostrou tão eficaz que o mesmo aluno segue dizendo:

(...) Este tipo de história nos faz pensar: quem é o culpado? Em um primeiro momento nós escolhemos Joe, entretanto, todo mundo ao redor de Joe tirou vantagem do crime: Ann, Mãe, Joe etc. Então a gente acha que todo mundo é culpado, mas em diferentes graus.Mas, como a gente consegue medir o grau de culpa (se a culpa é de um crime que matou muitas pessoas, pode ser mais difícil...)? Eu acho que 'All My Sons' levanta questões sobre o que é culpa e quem é culpado (...)

Novamente, o papel exercido pela forma é bastante significativo e foi enxergado e discutido por nós. O potencial dos alunos em enxergar e fazer conexões se mostrou inestimável. Como mencionado anteriormente, alguns alunos foram ao cinema assistir ao filme sobre Hannah Arendt e discutimos uma possível aproximação do conceito da 'Banalidade do Mal' (já mencionado em nossa dissertação) e a personagem de Joe Keller, que não se vê responsável pelo ato que "não cometeu" diretamente. Uma das alunas parece alcançar o cerne da crítica que Miller faz ao mencionar o filme 'O Leitor', que fora adaptado por David Hare de um romance alemão, cujo título é Der Vorleser, de Bernhard Schlink. O filme mostra a história de um advogado que se relaciona com uma moça mais velha, Hanna Schmitz, mas esta desaparece misteriosamente. Oito anos mais tarde ela reaparece no banco dos réus de um tribunal alemão sendo acusada de ter trabalhado na polícia nazista, a SS, durante a segunda guerra mundial e de ter matado vários judeus. Hanna, que assim como Joe Keller é uma pessoa comum e iletrada, não se enxerga como responsável por seus atos, assim como Eichmann, analisado por Hannah (coincidência?) Arendt. Uma das alunas, percebendo o caráter mais amplo contido na ação de Joe Keller após ter lido a peça disse: 
'Foi lembrada a personagem Hanna, do filme 'O Leitor', que da mesma forma não se dá conta do mal causado a tantas pessoas pelo seu ato. Todos acreditavam estar fazendo seu dever."

Tal conexão trouxe algo que instigou muito os alunos a irem atrás de peças e filmes que falassem sobre "responsabilidade". A mesma aluna que fizera a conexão de 'All My Sons' com o filme 'O Leitor' relata:

Para sorte nossa, nesse final de semana, o SESC Pinheiros encenou, por um grupo alemão, a peça 'Um Inimigo do Povo', de Ibsen, autor tido como referência para Arthur Miller. Fomos ao teatro e com isso complementamos essa interessante atividade que foi envolvente, fértil e prazerosa.

A ocasião de um debate público em que há troca de ideias, estudo histórico e reflexões profundas sobre a psique e ações humanas, não se restringe a uma data específica e nem somente ao contexto dos Estados Unidos. E esse é o maior legado de Arthur Miller, a prova maior de que sua literatura atinge o pilar daquilo que é mais humano, daquilo que é mais universal.

${ }^{* * *}$ Gostaria de agradecer a inestimável colaboração de todos os alunos envolvidos no projeto do semestre e, especialmente, aos que tiveram trechos de seus depoimentos transcritos aqui. São eles: Alda Gouveia, Cleusa Baruffaldi, Elizabeth Mitsutani, Maria Eugenia Sanfurgo, Nelson Ferreira e Thiago Gomes Verissimo. 


\section{ANEXO B \\ Dr. Stockmann: de Berlim para São Paulo, para denunciar as águas do Brasil.}

A peça "Um Inimigo do Povo" chegou em Setembro de 2013 a São Paulo, trazida diretamente da Alemanha por uma parceria entre $o$ Goethe-Institut e o SESC São Paulo. A peça faz parte do repertório da Companhia Schaubühne Berlim $^{533}$, a mais importante da Alemanha, e teve a adaptação livremente inspirada em Ibsen e feita por Florian Borchmeyer. Borchmeyer é um importante dramaturgo e diretor alemão que se juntou ao icônico e premiado diretor Thomas Ostermeier para fortificar ainda mais o conteúdo da peça. Encenada pelos atores do Berliner Schaubühne am Lehniner Platz, um dos mais importantes teatros alemães, a peça adotou um registro naturalista no qual a encenação foi marcada por longas pausas silenciosas e intervalos sem ação cênica nos quais os atores se engajavam em ações cotidianas (o que reforça ainda mais o registro naturalista adotado por Ostermeier). Entretanto, como lembra Charles Isherwood (jornalista do New York Times):

(...) the new production of Ibsen's "An Enemy of the People" (...) violently dismantles the fourth wall in the play's climactic scene, and all but turns the play into a public referendum on the current state of political and social culture. ${ }^{534}$

Tal atitude abriu o debate para o público que trouxe questões análogas à realidade brasileira para serem discutidas com a minoria que estava no poder (Peter Stockmann, Hovstad, Aslaksen e Billing). Foi dado um microfone à

\footnotetext{
${ }^{533}$ Fundada em 1962, a companhia de teatro Schaubühne destaca-se por suas montagens inovadoras de resistência política. Sob a direção de Thomas Ostermeier, desde 1999, a companhia tem apostado na versão de clássicos europeus à luz de contextos atuais. Ostermeier já dirigiu outras obras de Ibsen: em 2002, adaptou Nora baseando-se em Casa de Bonecas e, em 2005, montou sua versão de Hedda Gabler, situando-as no meio urbano e vinculando suas personagens à elite. O Inimigo do Povo teve sua estreia em 2012 no Festival de Avignon, na França, e foi encenada também em Melbourne, na Austrália.

534 [(...) A nova produção de Ibsen de "Um Inimigo do Povo" (...) violentamente desmonta a quarta parede na cena do clímax da peça, totalmente, mas transforma a peça em um referendo público sobre o estado atual da cultura política e social.]
} 
plateia e o que se viu foi um engajamento maciço do público ${ }^{535}$ com questões que a situação de Stockmann provocava no público. Uma questão que nos chamou a atenção foi a menção, por parte de um dos espectadores, à situação da construção da USP Leste, plantada em um solo tóxico e contaminado, assim como aquele em que o balneário da cidade de Stockmann se encontrava. Esse "debate" durante a assembleia de Stockmann, entretanto, se diferencia do que Ibsen coloca em sua peça e transforma a discussão sobre o destino de Stockmann em um: "Você decide ${ }^{536 " . ~ A ~ p e c ̧ a ~ n a ̃ o ~ e s t a ́ ~ p r e o c u p a d a ~}$ com isso. Aliás, a assembleia que Stockmann convoca na versão original é sufocada tanto pela minoria (os rapazes da imprensa e Peter) quanto pelo povo (influenciado por essa minoria), exceto pela figura do Bêbado.

Um outro ponto em que a peça se distancia da versão de lbsen, é no que diz respeito à construção das personagens: como podemos falar de 'Um Inimigo do Povo' cortando personagens essenciais, como Petra, Ejlif, Morten e Capitão Horster? O próprio Miller na adaptação situa (na rubrica) o peso de Petra dentro da dramaturgia ibseniana, lembrando que ela representava a esperança do futuro para Ibsen. Da mesma forma, o faz com relação ao Capitão Horster (que é fundamental para se entender que há alguém que apoia de fato Stockmann, assim como Petra e os meninos o fazem) e isso não se viu na adaptação de Borchmeyer. Aliás, um erro fatal, fruto provavelmente da escolha da direção, foi ter colocado Stockmann como um pateta, tropeçando, esbarrando e derrubando livros pela cena. Se há algo de cômico nele é a crença cega e firme de que ele sozinho conseguirá combater o poder instituído, e isso não tem nada a ver com o jeito de se comportar fisicamente em cena, através da caricatice.

\footnotetext{
${ }^{535}$ Este efeito, a propósito, era algo extremamente comum durante as apresentações das peças de Ibsen que muitas vezes terminavam com polícia do lado de fora, com pessoas sendo presas e sendo inclusive deportadas (como mencionamos na dissertação).

${ }^{536}$ A versão cinematográfica norueguesa 'En Folkefiende', dirigida por Erik Skjoldbjærg em 2004, segue a mesma opção transportando Stockmann para tempos atuais (mais especificamente ao contexto da cultura do espetáculo) e o destino de Stockmann passa a depender do voto dos espectadores do programa.
} 
Um outro aspecto importante a ser comentado, e que se relaciona à questão da forma da peça, é que seu caráter liberal ficou obscurecido. O caráter liberal desapareceu da produção não porque esta tenha enveredado pelo épico, mas porque se lançou de cabeça na postura pós-moderna que aposta no desmonte como perspectiva de representação que, na falta das utopias, desacreditadas pelo espetáculo, supostamente dá conta de representar a totalidade. Dr. Stockmann foi destruído pelos seus próprios ideais até certo ponto, mas o final aberto da versão original (no qual Stockmann e sua família encontram-se encurralados e prestes a serem atacados), afirma a ideia fundamental da peça de que é possível sim não vender a consciência. A montagem da Schaubühne optou por fazer com que Stockmann e sua esposa aceitassem o dinheiro das ações e isso acabou retirando a máxima Ibseniana do reconhecimento de que se está só e de que a queda é inevitável e é através dela que se chegará à consciência.

Após refletir sobre a adaptação trazida da Alemanha, depois de ver adaptações fílmicas de diferentes países, chegamos à conclusão de que Miller foi realmente fiel às questões formais e temáticas do original (e ainda por cima conseguiu fazer paralelos com o macarthismo, mesmo alterando algumas coisas). Enxergamos também como ele foi cauteloso em definir o que entendia pelo termo "adaptação". Isso atesta, de fato, que Miller parece mostrar um claro respeito pela ideia de autoria como propriedade intelectual, posição que diverge da postulada por Brecht, como já mencionamos na dissertação.

De qualquer maneira é importante que, mesmo com diferenças substanciais, haja o reavivamento de Ibsen que, com sua peça mais do que atual, nos trouxe diretamente da Alemanha um Doutor Stockmann que nos lembrou o quanto nossas águas estão poluídas e é preciso que não nos calemos. 


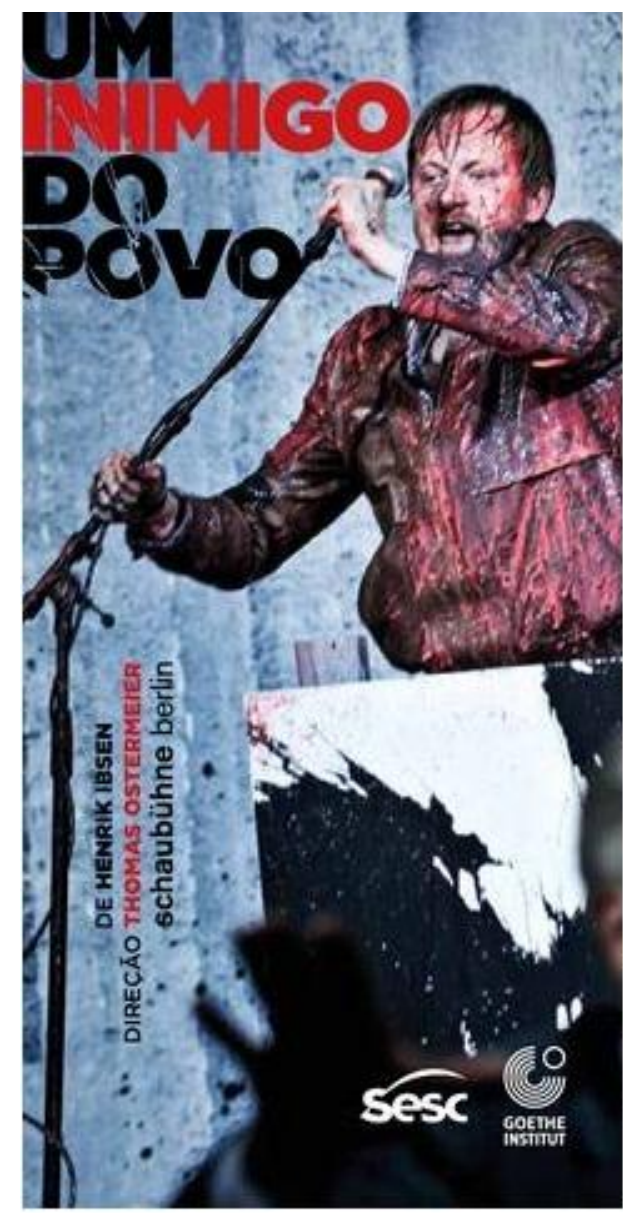

\section{FICHA TÉCNICA}

Autor: Henrik Ibsen

Direção: Thomas Ostermeier

Cenário: Jan Pappelbaum

Figurino: Nina Wetzel

Música: Malte Beckenbach, Daniel Freitag

Dramaturgia: Florian Borchmeyer

Iluminação: Erich Schneider

Pinturas nas Paredes: Katharina Ziemke

Dr. Stockmann: Stefan Stern

Councillor: Ingo Hülsmann

Mrs. Stockmann: Eva Meckbach

Hovstad: Christoph Gawenda

Aslaksen: David Ruland

Billing: Moritz Gottwald

Morten Kiil: Thomas Bading

\section{FONTES:}

1) http://www1.folha.uol.com.br/ilustrada/2013/09/1347174-o-teatro-esta-bemproximo-da-verdade-da-vida-diz-diretor-do-mitico-teatro-alemaoschaubuhne.shtml

2) http://www.nytimes.com/2013/11/08/theater/reviews/a-contemporary-enemyof-the-people-at-the-harvey-theater.html

3) http://www1.folha.uol.com.br/ilustrada/2013/09/1349478-critica-schaubuhneenfatiza-tom-politico-de-ibsen-e-mostra-tecnica-apurada.shtml 


\section{REFERÊNCIAS BIBLIOGRÁFICAS}

ABBAGNANO, Nicola. Dicionário de filosofia. Trad. Alfredo Bosi e Ivone

Castilho Benedetti. 4. ed. São Paulo: Martins Fontes, 2003.

ABBOTSON, Sue C.W. Student Companion to Arthur Miller. Greenwood Press. Westport, CT, 2000.

ADORNO, Theodor. W. Teoria Estética. Trad. Artur Morão. São Paulo, Martins Fontes, 1982.

ANDRADE, Jorge. Labirinto. Rio de Janeiro, Paz e Terra, 1978.

ANSPACH, Sílvia S. A ambígua identidade literário-cultural norte-americana: unilateralidade ou democracia? In: Revista Claritas do Departamento de Inglês - PUCSP, Ed.PUCSP EDUC, v.11, ํo1, p.59-82, 2005.

ARENDT, Hannah. Eichmann em Jerusalém. São Paulo: Companhia das Letras, 1999.

. Algumas Questões de Filosofia Moral. In: Arendt, $\mathrm{H}$.

Responsabilidade e Julgamento.Trad. Rosaura Eichenberg. São Paulo: Companhia das Letras, 2004.

Aristóteles. Poética. Trad. Eudoro de Souza. São Paulo: Nova Cultural, 1987.

BAUMAN, Zygmunt. Identidade. Trad. Carlos Alberto Medeiros, Jorge Zahar Editor, Rio de Janeiro, 2005. . Capitalismo Parasitário. Zahar: Rio de Janeiro, 2010.

BENTLEY, Eric. O dramaturgo como pensador: um estudo da dramaturgia nos tempos modernos: Wagner, Ibsen, Strindberg, Shaw, Pirandello, Sartre, Brecht. Rio de Janeiro, Civilização Brasileira, 1991. 
BERLOWITZ, Leslie; DONOHUE, Denis e MENAND Louis. (org) A América em Teoria. Rio de Janeiro, Forense Universitária, 1993.

BETTI, Maria S. No compasso do tempo: Arthur Miller (1915-2005). Oficina de Informações, São Paulo, SP, p. 31-33, 01 de março, 2005. . Breve Panorama da Prosa Teatral. Revista Cult, 05 maio 2009.

BIGSBY, Christopher. "Arthur Miller." A Critical Introduction to TwentiethCentury American Drama: Volume Two-Williams/Miller/Albee. Cambridge, Cambridge University Press, 1984. . Modern American Drama, 1945-1990. Cambridge, Cambridge University Press, 1992. . The Portable Arthur Miller. New York, Penguin Books, 1995. . The Cambridge Companion to Arthur Miller. Cambridge, Cambridge University Press, 1997. . Arthur Miller: a critical study. Cambridge, Cambridge University Press, 2005.

BLOOM, Harold (ed.). Arthur Miller, New York, Chelsea House, 1987. Arthur Miller's All My Sons. Chelsea House Publishers, New York, 1988.

BORDMAN, Gerald. The Concise Oxford Companion to American Theatre. New York: Oxford University Press, 1990.

BORNHEIM, Gerd. O sentido e a máscara. Ed. Perspectiva, São Paulo, 1992.

BRATER, Enoch. Arthur Miller: A Playwright's Life and Work. New York: Thames and Hudson, 2005. . (ed). Arthur Miller's America: Theater and Culture in a Time of Change. Ann Arbor: University of Michigan Press, 2005. . (ed). Arthur Miller's Global Theater. Ann Arbor: University of Michigan Press, 2007. 
BRUSTEIN, Robert. O teatro de protesto. Henrik Ibsen, August Strindberg e Anton Checov. Trad. Álvaro Cabral. Rio de Janeiro: Zahar, 1967.

CANDIDO, Antonio. Literatura e Sociedade. São Paulo: Companhia Editora Nacional, 1976.

CENTOLA, Steven, (ed.). The Achievement of Arthur Miller: New

Essays. Dallas, Texas: Contemporary Research, 1995. . Echoes down the corridor: collected essays, 1944-2000. New York, Penguin Books, 2001.

CÉZAR, Adelaide C. "O trágico enquanto marca do texto literário". Signum: estudos literários, Londrina, 1999, n.2.

CLARK, Norman. H. Deliver Us from Evil. New York: W.W. Norton \& Company Inc, 1976.

COSTA, Iná C. Panorama do Rio Vermelho: ensaios sobre o teatro americano moderno. São Paulo: Nankin, 2001.

DOWNER, Alan. Fifty years of American Drama, 1900 - 1950. Henry Regnery Publishing, Chicago, 1951.

EAGLETON, Terry. Teoria da Literatura: uma introdução. Trad. Waltensir Dutra, São Paulo, Martins Fontes, 2006.

ELIOT, Thomas Stearns. Tradition and Individual Talent. In: The Sacred Wood. New York: Alfred A. Knopf, 1921.

FALK, Andrew J. Upstaging the Cold War: American dissent and cultural diplomacy, 1940-1960. University of Massachusetts Press, 2011. 
FELDMAN, Alexandre D. A representação do holocausto e da queda na peça "After the Fall" de Arthur Miller. Dissertação (Dissertação de Mestrado em Estudos Linguísticos e Literários em Inglês pela FFLCH) - Universidade de São Paulo. Orientador: Maria Sílvia Betti, 2002. . O Éden de Arthur Miller. Elementos bíblicos e existencialistas na peca $A$ Criação do Mundo e Outros Negócios: seriedade e crítica em uma obra cômica. (Tese de Doutorado em Língua Hebraica, Literatura e Cultura Judaicas pela FFLCH) - Universidade de São Paulo. Orientador: Nancy Rosenchan, 2006.

FLORES, Fulvio. T. Nem só Bem Feitas, nem tão Melodramáticas: The Children's Hour e The Little Foxes, de Lillian Hellman. (Dissertação de mestrado em Estudos Linguísticos e Literários em Inglês pela FFLCH) Universidade de São Paulo: USP, 2008. Orientador: Maria Sílvia Betti.

FRIED, Albert (ed.). McCarthyism: the great American red scare: a documentary history. New York, Oxford University Press, 1990.

GOSSE, Van. The Movements of the New Left, 1950 - 1975: a brief history with documents. Bedford/St.Martin's, Boston/New York, 2005.

GOTTFRIED, Martin. Arthur Miller: His Life and Work. New York: Da Capo, 2003.

GOULD, Jean. Dentro e Fora da Broadway: o teatro moderno norte-americano. Trad. Ana Maria M. Machado. Rio de Janeiro, Bloch Editores, 1968.

HAMPTON, Christopher. An Enemy of the People: in a new version by Christopher Hampton. Faber and Faber, London, 1997.

HARALDSSON, Róbert H. Plotting against a Lie: a reading of Ibsen's An Enemy of the People. University of Iceland Press, 2004. 
HARTMOLL, Phyllis. The Theatre: a concise history. 3 ed. New York, Thames \& Hudson, 2006.

HOFTSTADTER, Richard. Anti-intellectualism in American Life. New York, Knopf, 1963. . The Paranoid Style in American Politics and Other Essays. Vintage Books: New York, 2008.

HOGAN, Robert. Arthur Miller. Tradução de Lígia Junqueira. São Paulo: Livraria Martins Editora, 1965.

HOUCHIN, J. H. Censorship of the American Theatre in the Twentieth Century. Cambridge: Cambridge University Press, 2003.

IBSEN, Henrik. An Enemy of the People. Dover Thrift Editions, London, 1999.

JACOBY, Susan. The Age of American Unreason. Vintage Books, New York, 2009.

JAGUARIBE, Beatriz. O choque do real: estética, mídia e cultura. Editora Rocco, Rio de Janeiro, 2007.

KARNAL, Leandro. [et al.]. História dos Estados Unidos: das Origens ao Século XXI. São Paulo: Contexto, 2007.

KIERNAN, Robert F. A Literatura Americana Pós 1945: um ensaio crítico. Editorial Nórdica, Rio de Janeiro, 1983.

KOTHE, Flávio R. O herói. 2.ed. São Paulo, Ática, 2000.

LEME, Viviane M. A concepção da tragédia moderna em "The Crucible" e "A View from the Bridge", de Arthur Miller. 2007. (Dissertação de Mestrado em Estudos Linguísticos e Literários em Inglês) - FFLCH-USP. Orientador: Maria Sílvia Betti. 
LESKY, Albin. A tragédia grega. Ed. Perspectiva, São Paulo, 1996.

LÉVINAS, Emmanuel. Entre Nós: Ensaios sobre a alteridade. Petrópolis: Vozes, 1997.

LIEVEN, Anatol. America Right or Wrong: An Anatomy of American

Nationalism. 2 ed. Oxford University Press, New York, 2012.

LINK, Arthur S. História Moderna dos Estados Unidos. Trad. Waltensir Dutra e outros. Rio de Janeiro, Zahar Editores, 1965.

LIPOVETSKY, Gilles. O Crepúsculo do Dever: a ética indolor dos novos tempos democráticos. Publicações Dom Quixote, Lisboa, 1994.

LUKÁCS, Georg. Introdução à Äesthetik de Hegel apud ROSENFELD, Anatol. O teatro épico. São Paulo, Perspectiva, 2002.

MAGALDI, Sábato. Prefácio. In: ANDRADE, Jorge. Labirinto. Rio de Janeiro. Paz e Terra, 1978.

. O Texto no Teatro. São Paulo: Perspectiva, 1989. . O texto no teatro. São Paulo, Perspectiva, 2001.

MARTIN, Robert A; CENTOLA, Steven R. (ed). The Theater Essays of Arthur Miller. Ed.Rev. New York, Capo Press, 1996.

MASON, Jeffrey. Stone Tower: The Political Theater of Arthur Miller. The University of Michigan Press, 2011.

MILLER, Arthur. An Enemy of the People. New York, Penguin Books, 1979. . Timebends: A Life. New York, Harper and Row Publishers, 1987. . All My Sons: a play in three acts. London, Penguin Books, 2000. 
. On politics and the art of acting. New York, Vikin, 2001.

MOSES, Montrose J. Henrik Ibsen: The Man and His Plays. Hong Kong: Forgotten Books, 2013 (Original work published 1908).

MOSS, Leonard. Arthur Miller. 2nd. ed. New York: Twayne, 1980.

MURPHY, Brenda. "Arthur Miller: Revisioning Realism." Realism and the American Dramatic Tradition. Ed. William W. Demastes. Tuscaloosa: University of Alabama Press, 1996. . Congresstional Theatre: Dramatizing McCarthyism on Stage, Film, and Television. Cambridge, Cambridge University Press, 1999.

NAVASKY, Victor S. Naming names. New York, Hill and Wang, 2003.

OTTEN, Terry. The Temptation of Innocence in the Dramas of Arthur Miller. Columbia: University of Missouri Press, 2002.

PALLOTTINI, Renata. O que é dramaturgia. Ed. Brasiliense, 2011.

PAVIS, Patrice. Dictionary of the Theatre: Terms, Concepts, and Analysis. Toronto: University of Toronto Press Incorporated, 1998.

PETERSON, Deborah C. Fredric March: Craftsman First, Star Second. Greenwood Press, 1996.

PILAGALLO, Oscar. Nota Editorial. Entrelivros: Panorama da Literatura Americana, Duetto Editorial - São Paulo, 2007.

PITA, Fernando. A reversibilidade do texto teatral rodrigueano. In: Palimpsesto 3. Rio de Janeiro, Caetés, 2003.

PRADO, Décio de Almeida. Teatro em Progresso: crítica teatral, 1955 - 1964. São Paulo, Perspectiva, 2002. 
RANA, Aziz. The Two Faces of American Freedom. Harvard University Press, London, 2010.

RANCIÈRE, Jacques. Dissensus: on politics and aesthetics. Edited and translated by Steven Corcoran, New York, Continuum, 2010.

ROSENFELD, Anatol. Prismas do Teatro. Ed. Perspectiva, São Paulo, 2000. . O teatro épico. São Paulo, Perspectiva, 2002. . A Arte do Teatro: aulas de Anatol Rosenfeld. Transcrição por Neusa Martins. São Paulo: Publifolha, 2009.

ROUDINE, Jean-Jacques. Introdução às grandes teorias do teatro. Jorge Zahar Ed, RJ. Trad. André Telles, 2003.

RUSSO, Thiago P. Ibsen's Revolutionizing Theater: on and offstage. In: Revista Crop (Revista de Estudos Linguísticos e Literários em Inglês da USP) №14/2010, p.44-53.

SANTOS, Adilson dos. A tragédia grega: um estudo teórico. Revista de Pós Graduação de Linguística e Literatura da Universidade Federal de Pernambuco: Vol. 18, N¹, Julho/2005.

SCHRECKER, Ellen. The Age of McCarthyism: a brief history with documents. 2nd ed. Boston, Bedford/St.Martin's, 2002.

SHAKESPEARE, William. Julius Caesar. Arthur Humphreys (Ed). Oxford University Press, New York, 1999.

SIEBOLD, Thomas (ed). Readings on Arthur Miller. San Diego: Greenhaven, 1997.

SILVA, Jane Pessoa. "Ibsen no Brasil: historiografia, seleção de textos críticos e catálogo bibliográfico". (Dissertação de mestrado do departamento de Teoria 
Literária em três volumes - FFLCH). Universidade de São Paulo. Orientador: Iná Camargo Costa, 2007.

STORY, Ronald and LAURIE, Bruce. The Rise of Conservatism in America, 1945 - 2000. Bedford/St.Martin's, Boston/New York, 2008.

SZONDI, Peter. Teoria do Drama Moderno: 1880-1950. Trad. Luiz Sérgio Rêpa. São Paulo, Cosac \& Naify, 2001.

THODY, Philip \& READ, Howard. Introducing Sartre: a graphic guide. Icon Books, London, 2011.

THOMSON, Peter \& SACKS, Glendyr. The Cambridge Companion to Brecht. Cambridge, Cambridge University Press, 1994.

TOTA, Antonio P. Os Americanos. São Paulo, Editora Contexto, 2009.

TUTU, Desmond. In: Ending Poverty As We Know It: Guaranteeing a Right to a Job at a Living Wage by William P. Quigley, 2003.

VERNANT, Jean-Pierre. Entre mito \& política. Trad. Cristina Murachco. São Paulo: Editora da Universidade de São Paulo, 2001.

VIDAL, Gore. Imperial America: reflections on the United States of Amnesia. New York: Nation Books, 2004.

VOILQUIN, Jean \& CAPELLE, Jean. "Introdução". In: ARISTÓTELES. Arte retórica e arte poética. Trad. Antônio Pinto de Carvalho. São Paulo: Difusão Européia do Livro, 1964.

WEALES, Gerald. Arthur Miller. In: Downer, Alan. S (ed). The American Theater. Washington: Voice of America, 1967. (ed). The Crucible: text and criticism. New York, Penguin Books, 1996. 
WERTHEIM, Albert. The McCarthy Era and the American Theatre. In: Insurgency in American Theatre, Vol.34, May No. 2. The John Hopkins University Press, 1982.

WILLIAMS, Raymond. The Realism of Arthur Miller. Critical Quarterly 1, 1959. . Drama from Ibsen to Brecht. London, Hogarth Press, 1993. . Cultura. São Paulo: Paz e Terra, Trad. Lólio Lourenço de

Oliveira, 2000. . Tragédia Moderna. Trad. Betina Bishof. São Paulo: Cosac \& Naify, 2002.

WOLIN, Sheldon. Democracy Incorporated: Managed Democracy and the Specter of Inverted Totalitarianismo. Princeton University Press, New Jersey, 2008.

WOOD, Ellen M. Democracia contra o capitalismo: a renovação do materialismo histórico. Trad. Cezar Castanheira, São Paulo, Boitempo, 2003.

YOUNG, Julian. The Philosophy of Tragedy: from Plato to Žižek. Cambridge University Press, New York, 2013.

ZANOTTO, Ilka Marinho. Nova Dramaturgia. GUINSBURG, J.; FARIA, João Roberto; LIMA, Mariangela Alves de.(Orgs.). Dicionário do Teatro Brasileiro: temas, formas e conceitos. 2.ed. rev. e ampl. São Paulo: Perspectiva/ Edições SESC SP, 2009. 
REFERÊNCIAS FILMOGRÁFICAS (por ordem alfabética de título):

- Crossing Over (2009), dirigido por Wayne Kramer. Título em português:

Território Restrito.

- Duck and Cover (1952), dirigido por Anthony Rizzo.

- Edward R. Murrow: The McCarthy Years (2005), produzido por Roger Birnbaum e Ken Ross.

- En Folkefiende (2004), dirigido por Erik Skjoldbjærg.

- Good Night, and Good Luck (2005), dirigido por George Clooney. Título em português: Boa Noite e Boa Sorte.

- Henrik Ibsen: Dramatist (2006), dirigido por Steinar Hybertsen.

- House of UnAmerican Activities (2009), dirigido por Frederick Marx.

- Les Sorcières de Salem (1957), dirigido por Raymond Rouleau. Versão de Jean-Paul Sartre, com título em português de: As Virgens de Salém.

- None Without Sin: Arthur Miller, Elia Kazan and the Blacklist (2003), dirigido por Michael Epstein.

- Point of order! (1964), dirigido por Emile de Antonio.

- Scandalize My Name: stories from the blacklist (2004), dirigido por Alexandra Isles.

- Seeing Red (2009), dirigido por Annie Goldson.

- The Crucible (1996), dirigido por Nicholas Hytner. Título em português: As Bruxas de Salém. 